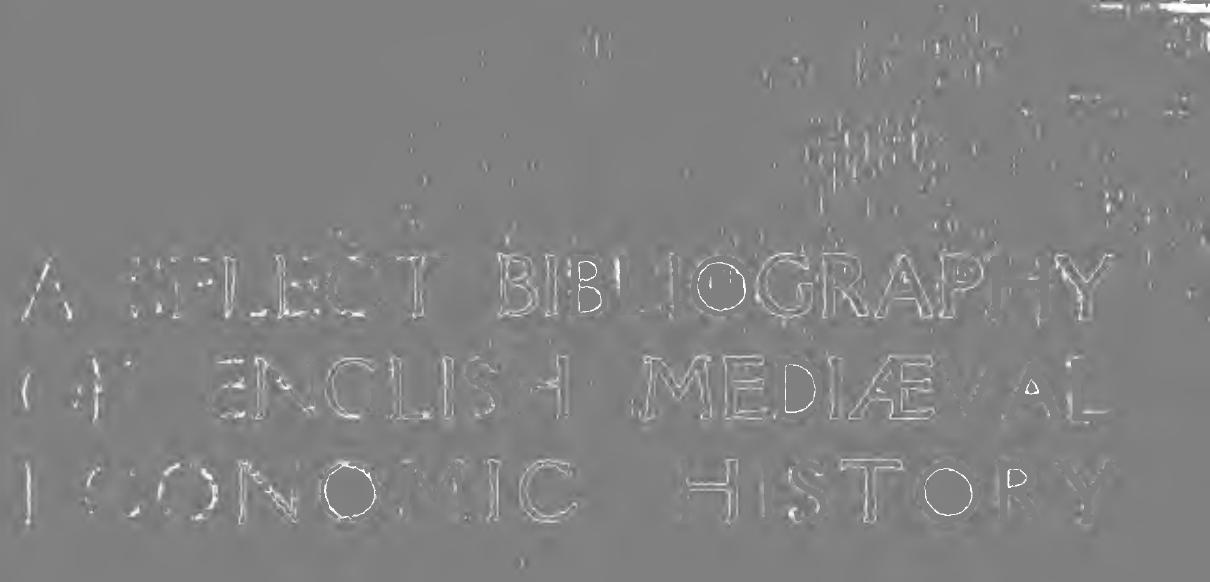


THE LONDON SCHOOL OF ECONOMICS AND POLITICAL SCIENCE.

(UNIVERSITY OF LONDON)

TELCFMONE 331 CENTRAL.

TELEOMAW: "FOLECONICS, ESTRANO"
CLARE MARKET, LONDON, w.c.

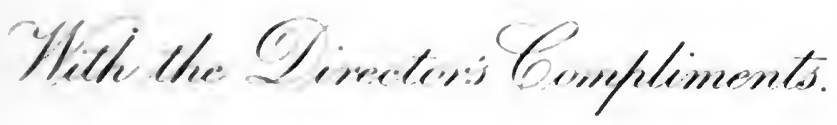




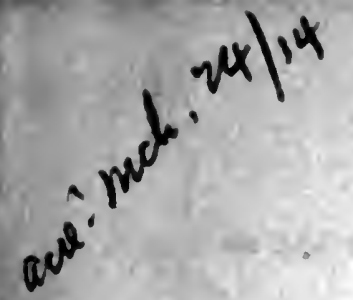





\section{STUDIES IN ECONOMICS AND POLITICAL SCIENCE.}

Editzd ay the Dirxctor of th8 London School of Economics.

No. 4 in the Series of Bibliographien by Studento conoected

with the London School of Economico and Political Science.

A SELECT BIBLIOGRAPHY FOR THE STUDY, SOURCES, AND LITERATURE OF ENGLISH MEDIÆVAL ECONOMIC HISTORY 



\title{
A SELECT BIBLIOGRAPHY
}

FOR THE STUDY, SOURCES, AND LITERATURE OF ENGLISH MEDIÆVAL ECONOMIC HISTORY

\author{
COMPILED BY A SEMINAR \\ OF THE LONDON SCHOOL \\ OF ECONOMICS UNDER THE \\ SUPERVISION OF \\ HUBERT HALL, F.S.A. \\ READER IN PALEOGRAPUY AND ECONOMIC \\ HISTORT IN THE UNIVERSITT OF LONDON
}

\section{LONDON \\ P. S. KING \& SON \\ ORCHARD HOUSE, WESTMINSTER




\section{PREFACE}

THE objects and method of the Select Bibliography of Medixval Economic History printed in the following pages need a few words of explanation. In the first place it should be explained that this undertaking had its origin in a mere academic discipline. In order to complete the equipment of the students of this department of the London School of Economics, it seemed desirable that special attention should be given to the sources and literature of Mediæval Economic History. It had been noticed that, in most cases, students showed a marked aversion from this branch of study; but apart from this needful exercise, there was no general Bibliography of the subject available for reference.

The present contribution is not meant to fill this void; but it may perhaps serve as a stepping-stone for other students. It is merely the outcome of a series of lectures on the theory of Historical Bibliography and the distribution of Historical Sources delivered several years ago. The practical aspect of these studies was subsequently discussed and investigated by a Seminar, in which the present work has been compiled, under many difficulties.

The leisure at the disposal of graduate students in London is not usually considerable, and a Seminar meeting once a week during the academic year might discuss ad infinitum the vexed questions arising out of the neglected studies of Historical Sources and Bibliography. Again, owing to various unavoidable causes, several members of the Seminar have been compelled to abandon their tasks, and new workers have had to be instructed. In course of time it 
became necessary, for academic reasons, to turn to other subjects of study and research before the work in hand was completed, and as it was already nearly two years in arrears the academic vacations have been utilised for the purpose of passing the Bibliography through the press.

As to the method of the work, it is desirable that the following explanations should be given :-

I. Under cover of the title, the niceties of bibliographical descriptions have been dispensed with in order to save space and to conform with the general use of "short titles" in modern classified lists of Historical Sources. The scientific aspects of Bibliography had already been studied as an academic discipline. In particular it may be noticed that the place of publication of English works is London, unless otherwise stated.

2. The chief object of the work being to assist future students of the School to prepare themselves for the serious study of the sources of Mediæval Economic History, some attention has been given to the "Instruments of Study," although this apparatus may appear tedious to bookmakers in search of specific titles.

3. For similar reasons, the original manuscript sources have been somewhat fully described, partly for the purpose of giving further information upon a very obscure subject and also to stimulate the use of the comparative study of Economic and Social con ditions on the Continent during a period in which those conditions on both sides of the Channel were closely assimilated.

4. The latter motive has also induced the compilers to give occasional references in Part III of this Bibliography to the modern Continental literature of the subject. It will be evident that the selection made here is not exhaustive and is even arbitrary; but, apart from the exigencies of space, some difficulty was found in securing contributors to this part of the undertaking 
owing to professional and other occupations. It was originally intended to issue the portion dealing with the Continental sources and literature as a separate volume, but as time and materials were equally lacking for such an enterprise, it was decided to include the titles which had been collected, in the hope that they might facilitate the comparative studies referred to above. It will also be observed that the archives and other sources of Scottish, Irish, and Welsh history have been treated as distinct national interests in accordance with the general tendency of modern research.

5. The classification adopted here is in some respects an original one, inasmuch as it is based chiefly on the actual distribution of the Sources. In other respects it is more or less conventional, with some departures from the stereotyped arrangement of bibliographical sections. Archrological remains or exhibits have been briefly noticed as a means of supplementing the documentary sources.

6. It should be clearly understood that, for the reasons stated above, this Bibliography does not include titles of works published later than the year I910, with a few exceptions.

The lecturer has to assume responsibility for some part of the classification, for the descriptive headings, and (as far as the time at his disposal permitted) for passing the work through the press.

The following members of the Seminar collaborated in the collection and selection of the titles: Miss A. B. Wallis Chapman, D.Sc. (Econ.); Miss Irene Churchill, Mod. Hist. Honours School, Oxford; Miss A. E. Conway, Mod. Hist. Tripos, Cambridge; Miss H. L. E. Garbett (Victoria Counties History); Miss M. Lane, M.A.; Miss G. R. Lewis; Miss M. F. Moore, M.A.; Miss E. E. le P. Power, Mod. Hist. Tripos, Cambridge; Miss Alice Raven (Victoria Counties History); Mr. H. G. Richardson, M.A., B.Sc. (Econ.), A. Zaleski, B.Sc. (Econ.). 
viii

Miss Moore has also compiled the Index, and Mr. Richardson has contributed some editorial matter.

The compilers have to acknowledge, with gratitude, the interest taken in their work by Miss Mactaggart, the Secretary of the School, and the assistance given to them by Mr. G. F. Barwick, of the British Museum, Mr. Hilary Jenkinson, M.A., F.S.A., of the Public Record Office, Mr. B. M. Headicar, Librarian of the School, and by the Printers.

September, 1913.

H. H. 


\section{TABLE OF CONTENTS}

Preface

PART I.-Introductory: The Study of Engllsh

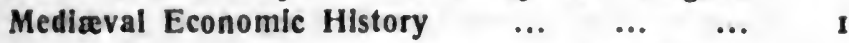

Section 1.-The Instruments of Study and Research ...

Division I.-Bibliographies of Printed Studies, Sources, and Literature ...

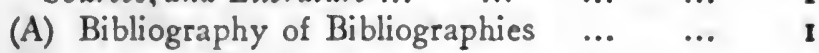

(B) General Bibliographies $\quad \ldots \quad$...

$\begin{array}{lllll}\text { (a) Library Catalogues... } & \ldots & \ldots & \ldots & 2\end{array}$

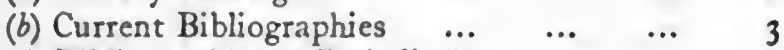

(c) Bibliographies of Periodicals $\quad \ldots \quad \ldots \quad 3$

(d) Bibliographies of Learned Societies $\quad \ldots \quad 4$

(e) Special Repertories of General Bibliography 4

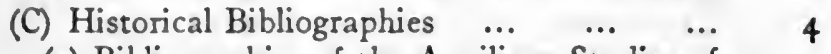

(a) Bibliographies of the Auxiliary Studies of Historical Method: Palæography and Diplomatic $\ldots \ldots, \quad \ldots$

$\begin{array}{lllllll}\text { Sigillography } & \ldots & \ldots & \ldots & \ldots & 5 \\ & & & \ldots & & \end{array}$

$\begin{array}{llllll}\text { Numismatics } & \ldots & \ldots & \ldots & \ldots & 6\end{array}$

$\begin{array}{llllll}\text { Archæology } & \ldots & \ldots & \ldots & \ldots & 7\end{array}$

Biography, Genealogy, and Heraldry $\quad \ldots \quad 8$

$\begin{array}{llll}\text { Geography and Topography } & \ldots & \ldots & 8\end{array}$

(b) Bibliographies of Universal History $\quad \ldots \quad 9$

(c) Bibliographies of the Middle Ages... $\quad \ldots \quad 9$

(d) Bibliographies of National History $\quad \ldots \quad 9$

$\begin{array}{lllllll}\text { England } & \ldots & \ldots & \ldots & \ldots & \ldots & 9\end{array}$

$\begin{array}{lllllll}\text { Scotland } & \ldots & \ldots & \ldots & \ldots & \ldots & 9\end{array}$

$\begin{array}{lllllll}\text { Ireland } & \ldots & \ldots & \ldots & \ldots & \ldots & \text { 10 }\end{array}$

$\begin{array}{lllllll}\text { Wales } & \ldots & \ldots & \ldots & \ldots & \ldots & \text { 10 }\end{array}$

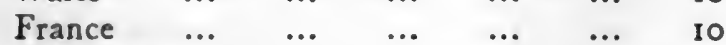

$\begin{array}{lllllll}\text { Germany } & \ldots & \ldots & \ldots & \ldots & \ldots & 10\end{array}$

$\begin{array}{lllllll}\text { Italy } & \ldots & \ldots & \ldots & \ldots & \ldots & \text { II }\end{array}$

$\begin{array}{llllll}\text { Low Countries } & \ldots & \ldots & \ldots & \ldots & \text { II }\end{array}$ 
(C) Historical Bibliographies-cont.

$\begin{array}{lllll}\text { Peninsular Kingdoms } & \ldots & \ldots & \ldots & \text { 12 }\end{array}$

Scandinavian Kingdoms ... $\quad \ldots \quad \ldots \quad \ldots \quad 12$

(e) Bibliographies of Special Branches of Mediæval History (Political, Constitutional, Legal, Ecclesiastical, Naval and Military, Economic and Social, and Local History)...

(f) Bibliographies of Special Historical Subjects

Division II.-Inventories of Records and State Archives ...

$\begin{array}{lllllll}\text { England } & \cdots & \cdots & \cdots & \cdots & \cdots & \cdots\end{array}$

$\begin{array}{llllllll} & \cdots & \cdots & \cdots & \cdots & \cdots & \cdots & 16\end{array}$

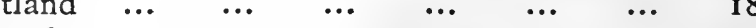

$\begin{array}{llllllll}\text { Ireland } & \ldots & \ldots & \ldots & \ldots & \ldots & \ldots & \text { 19 }\end{array}$

$\begin{array}{llllllll}\text { Wales } & \ldots & \ldots & \ldots & \ldots & \ldots & \ldots & \text { 19 }\end{array}$

$\begin{array}{llllllll}\text { France } & \ldots & \ldots & \ldots & \ldots & \ldots & \ldots & 19\end{array}$

$\begin{array}{llllllll}\text { Belgium } & \ldots & \ldots & \ldots & \ldots & \ldots & \ldots & 2 \text { I }\end{array}$

$\begin{array}{lllllll}\text { Netherlands } & \ldots & \ldots & \ldots & \ldots & \ldots & 22\end{array}$

Germany, Austria-Hungary, and Switzerland ... 23

$\begin{array}{llllllll}\text { Italy } & \ldots & \ldots & \ldots & \ldots & \ldots & \ldots & 25\end{array}$

Peninsular Kingdoms (Spain and Portugal) $\quad \ldots \quad 27$

Scandinavian Kingdoms (Denmark, Norway,

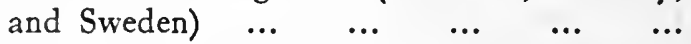

Division III.-Inventories of Local Records,

Provincial Archives and other Muniments. Catalogues of Libraries, and Private Collections of MSS.

England

$\begin{array}{lllllll}\text { Scotland } & \ldots & \ldots & \ldots & \ldots & \ldots & 32\end{array}$

$\begin{array}{llllllll}\text { Ireland } & \ldots & \ldots & \ldots & \ldots & \ldots & \ldots & 36 \\ & \ldots & \ldots & \ldots & \ldots & \ldots & \ldots & 37\end{array}$

$\begin{array}{llllllll}\text { Wales } & \ldots & \ldots & \ldots & \ldots & \ldots & \ldots & 37\end{array}$

$\begin{array}{llllllll}\text { France } & \ldots & \ldots & \ldots & \ldots & \ldots & \ldots & 37\end{array}$

$\begin{array}{llllllll}\text { Belgium } & \ldots & \ldots & \ldots & \ldots & \ldots & \ldots & 38\end{array}$

$\begin{array}{llllllll}\text { Germany } & \ldots & \ldots & \ldots & \ldots & \ldots & \ldots & 39\end{array}$

$\begin{array}{llllllll}\text { Italy } & \ldots & \ldots & \ldots & \ldots & \ldots & \ldots & 39\end{array}$

$\begin{array}{llllllll}\text { Spain } & \ldots & \ldots & \ldots & \ldots & \ldots & \ldots & 39\end{array}$

Division IV._Catalogues of Museums $\quad \ldots \quad$... 40

$\begin{array}{llllllll}\text { England } & \ldots & \ldots & \ldots & \ldots & \ldots & \ldots & 4 \text { I }\end{array}$

$\begin{array}{llllllll}\text { Scotland } & \ldots & \ldots & \ldots & \ldots & \ldots & \ldots & 42\end{array}$

$\begin{array}{llllllll}\text { Ireland } & \ldots & \ldots & \ldots & \ldots & \ldots & \ldots & 42\end{array}$

$\begin{array}{llllllll}\text { France } & \ldots & \ldots & \ldots & \ldots & \ldots & \ldots & 43\end{array}$ 
Section II.-Auxiliary Studies $\quad \ldots \quad$...

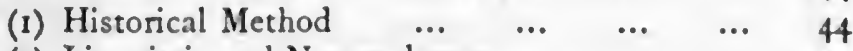

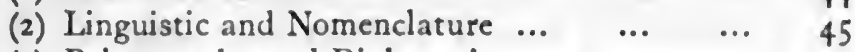

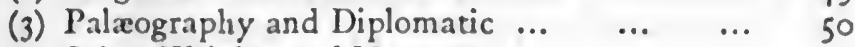

(4) Coins, Weights and Measures $\quad \ldots \quad$... $\quad \ldots \quad 58$

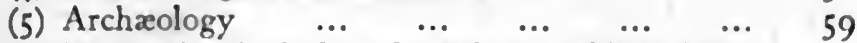

(6) Biography (including Genealogy and Heraldry) 65

(7) Geography and Topography $\quad \ldots \quad$..

Section III.-General Authorities $\quad \ldots \quad \ldots \quad 7$ I

(1) Histories of the World or of Civilisation $\quad \ldots \quad 7 \mathrm{I}$

(2) Histories of Continents or Regions $\ldots \quad \ldots \quad 71$

(3) Histories of Epochs (The Middle Ages) $\quad \ldots \quad 72$

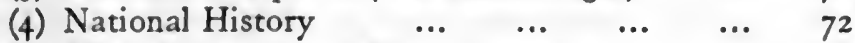

(5) Special Branches of History $\quad \ldots \quad \ldots \quad \ldots \quad \ldots \quad 76$

PART II.-The Sources of Mediæval Economic History 81

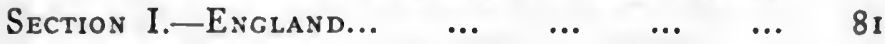

Division I._Public Records... $\quad \ldots \quad \ldots \quad \ldots \quad \ldots \quad 81$

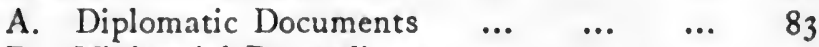

B. Ministerial Proceedings $\quad \ldots \quad$...

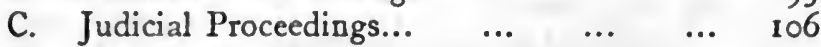

D. Miscellaneous Records $\quad \ldots \quad \ldots \quad \ldots \quad \ldots \quad 110$

Division II.-Local Records and Literary MSS... II I

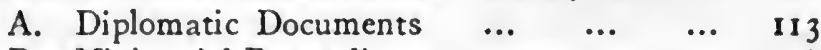

B. Ministerial Proceedings $\quad \ldots \quad$... $\quad \ldots \quad 118$

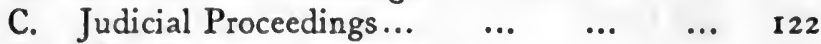

D. Miscellaneous Records $\quad \ldots \quad \ldots \quad \ldots \quad \ldots \quad 125$

Section II.-England's Sister Kingdoms... $\quad$.. $\quad 129$

$\begin{array}{llllllll}\text { (1) Scotland } & \ldots & \ldots & \ldots & \ldots & \ldots & \ldots & 129\end{array}$

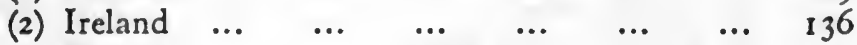

(3) Wales $\quad \ldots \quad$. $\begin{array}{lllllll} & \ldots & \ldots & \ldots & \ldots & \ldots & 140\end{array}$

Section III.-England's Continental Neighbours 145

$\begin{array}{llllllll}\text { (1) France } & \ldots & \ldots & \ldots & \ldots & \ldots & \ldots & 155\end{array}$

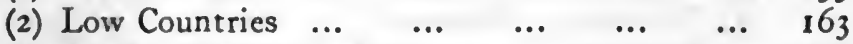

(3) Empire (Germany, etc.)... $\quad \ldots \quad \ldots \quad \ldots \quad \ldots \quad$ I66

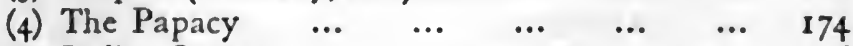

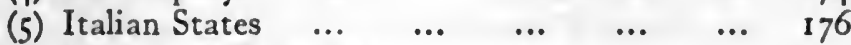

$\begin{array}{llllll}\text { (6) Peninsular Kingdoms } & \ldots & \ldots & \ldots & \ldots & 177\end{array}$

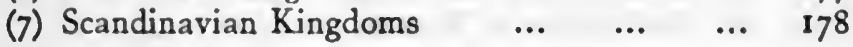




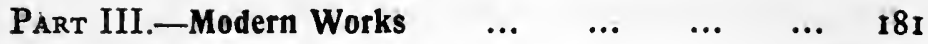

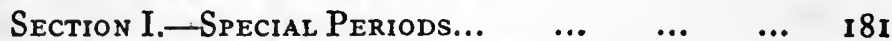

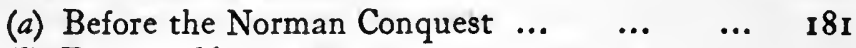

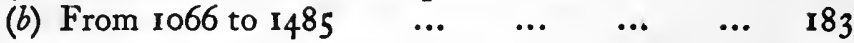

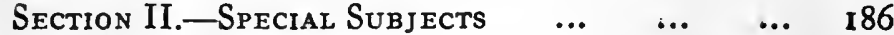

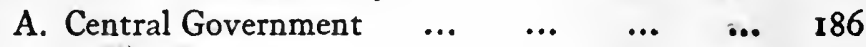

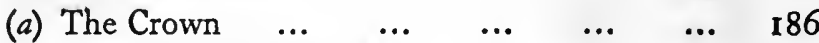

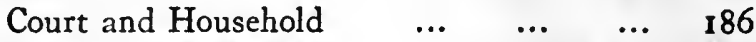

Departments of State $\quad \ldots \quad \ldots \quad \ldots \quad \ldots \quad 188$

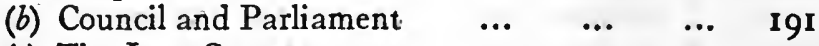

$\begin{array}{llllll}\text { (c) The Law Courts } \quad \ldots & \ldots & \ldots & \ldots & 193\end{array}$

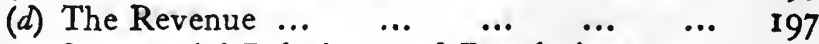

(e) Commercial Relations and Regulations ... 201

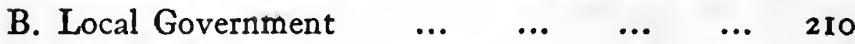

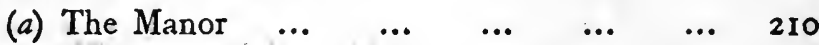

History and Franchises $\quad \ldots \quad \ldots \quad \ldots \quad$ 2 I0

$\begin{array}{lllll}\text { Tenures and Services } & \ldots & \ldots & \ldots & 216\end{array}$

$\begin{array}{llllll}\text { Agrarian Economy } & \ldots & \ldots & \ldots & \ldots & 221\end{array}$

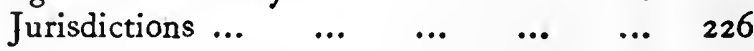

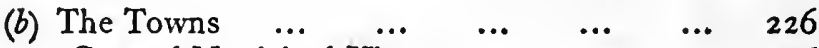

$\begin{array}{lllll}\text { General Municipal History } & \ldots & \ldots & \ldots & 226\end{array}$

$\begin{array}{lllll}\text { Local Municipal History } & \ldots & \ldots & \ldots & 228\end{array}$

Histories of Towns in Special Periods or of

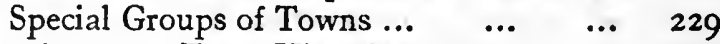

Specimens of Town Histories $\quad \ldots \quad \ldots \quad$... 231

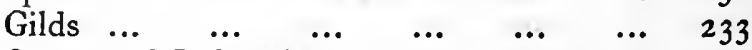

$\begin{array}{lllll}\text { Crafts and Industries } & \ldots & \ldots & \ldots & 235\end{array}$

$\begin{array}{llllll}\text { Fairs and Markets } & \ldots & \ldots & \ldots & \ldots & 238\end{array}$

$\begin{array}{llllllll}\text { C. The Church } & \ldots & \ldots & \ldots & \ldots & \ldots & 238\end{array}$

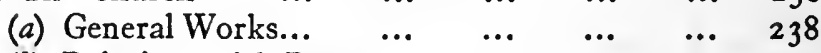

(b) Relations with Rome ... $\quad \ldots \quad$... $\quad$.. $\quad 240$

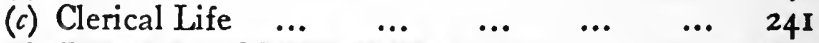

(d) Revenue and Endowments $\quad \ldots \quad$... $\quad$.. $\quad 242$

(c) Miscellaneous Sources of Revenue $\quad \ldots \quad$... $\quad 243$

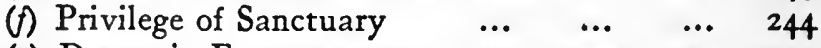

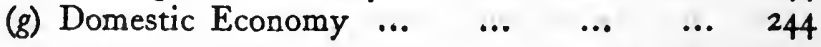

$\begin{array}{lllllll}\text { D. Social Conditions } & \ldots & \ldots & \ldots & \ldots & 249\end{array}$

$\begin{array}{llllll}\text { (a) Classes of Society } \quad \ldots & \ldots & \ldots & \ldots & 249\end{array}$

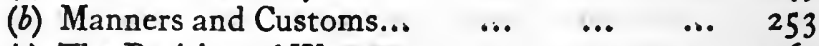

(c) The Position of Women $\quad \ldots \quad$... $\quad \ldots \quad 260$ 


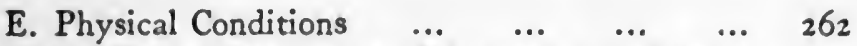

(a) Physical features and Sports or Industries relating thereto $\quad \ldots \quad \ldots \quad \ldots \quad \ldots \quad \ldots \quad 262$ $\begin{array}{lllllll}\text { I. Forests } & \ldots & \ldots & \ldots & \ldots & \ldots & 262\end{array}$

2. Rivers and Marshes $\quad \ldots \quad$... $\quad \ldots \quad 264$

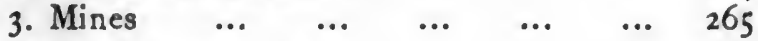

(b) Means of Communication $\quad \ldots \quad \ldots \quad \ldots \quad \ldots \quad 266$ $\begin{array}{lllllll}\text { Roads ... } & \ldots & \ldots & \ldots & \ldots & \ldots & 266\end{array}$ $\begin{array}{lllllll}\text { Bridges } & \ldots & \ldots & \ldots & \ldots & \ldots & 267\end{array}$

(c) Public Health and Population $\quad \ldots \quad \ldots \quad 268$

$\begin{array}{llllll}\text { F. Economic Thought } & \ldots & \ldots & \ldots & \ldots & 269\end{array}$

Appendix A.: Publications of Learned Societies ... 273

$\begin{array}{llllllll}\text { 1. England } & \ldots & \ldots & \ldots & \ldots & \ldots & \ldots & 273\end{array}$

$\begin{array}{lllllll}\text { (a) Central ... } & \ldots & \ldots & \ldots & \ldots & \ldots & 273\end{array}$

$\begin{array}{cccccccc}\text { 2b) Local } & \ldots & \ldots & \ldots & \ldots & \ldots & \ldots & 274 \\ \text { 2. Scotland } & \ldots & \ldots & \ldots & \ldots & \ldots & \ldots & 278\end{array}$

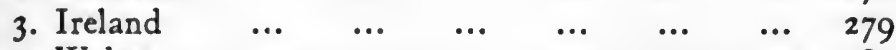

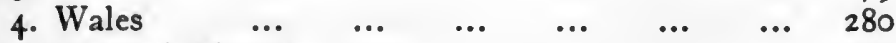

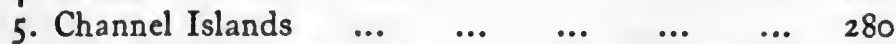

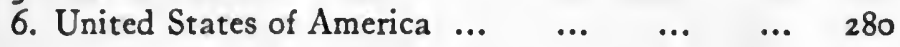

Appendix B.: Select List of British and American

Periodical Publications containing contributions to

the Study of Mediaval Economic History ... ... 281

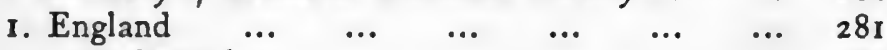

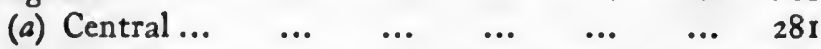

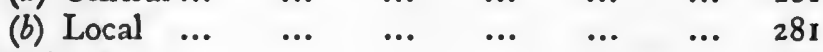

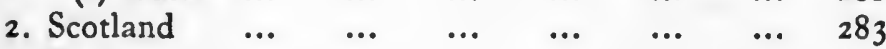

$\begin{array}{llllllll}\text { 3. Wales } & \ldots & \ldots & \ldots & \ldots & \ldots & \ldots & 283\end{array}$

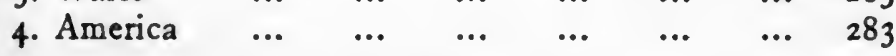

$\begin{array}{lllllllll}\text { Index } & \ldots & \ldots & \ldots & \ldots & \ldots & \ldots & \ldots & 284\end{array}$ 


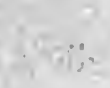

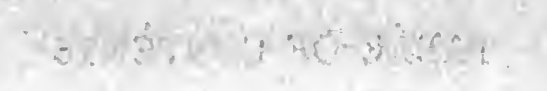

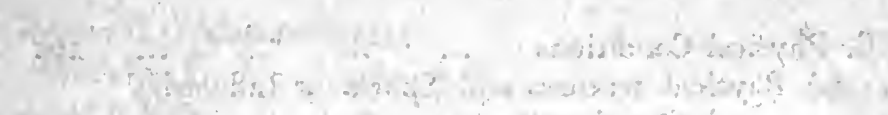

$$
\begin{aligned}
& \text { 5. } \\
& \text {, } \\
& \text { i. }
\end{aligned}
$$

$19:=-1$

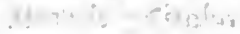

U.

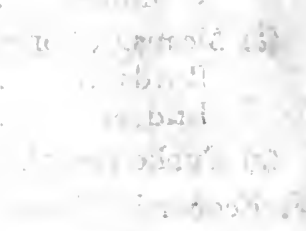

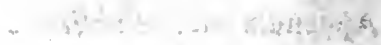

?

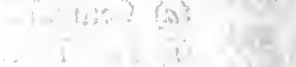

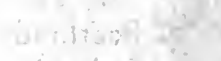

$\operatorname{lng} 3 \mathrm{sil}^{2}$ $\therefore y^{2} \div$

a.

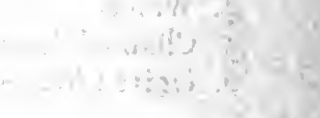

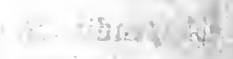

$x^{3}, 3$

in.

net:

$(4) \cdot 6-5$

48: 2:

An:

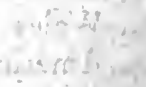

$x e$
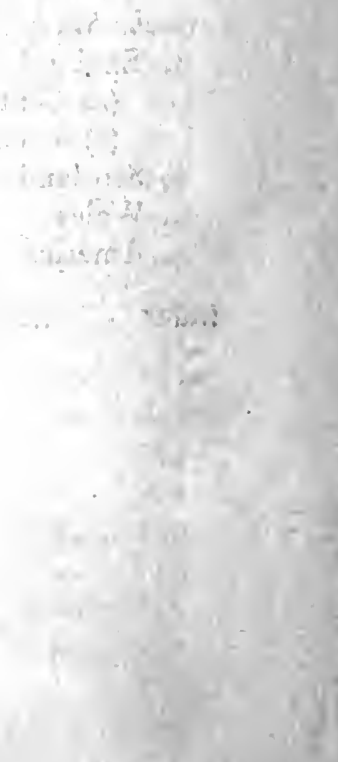


\section{A SELECT BIBLIOGRAPHY FOR THE STUDY, SOURCES, AND LITERATURE OF ENGLISH MEDIEVAL ECONOMIC HISTORY.}

Part I.-Introduction: The Study of English Medieval Economic History.

Section I.-The Instruments of Study and Research.

\section{Division 1.-BIBLIOGRAPHIES OF PRINTED STUDIES, SOURCES AND LITERATURE.}

In this division of the "Instruments" will be found some select Bibliographies of Historical Studies and Literature arranged according to the plan described in the Preface. These Bibliographies have reference both to the selected works treating of the Auxiliary Studies of History and to the General Authorities which will be found below in Sections II. and III. respectively.

\section{(A) Bibliography of Bibliographies.}

1. Courtney, W. P. Register of National Bibliography. 1905.

2. London, British Museum. List of Bibliographical works in the Reading Room (G. K. Fortescue), 1889 .

3. Stein, H. Manuel de Bibliographie Générale Paris, 1897.

4. VallÉE, LÉON. Bibliographie des Bibliographies, I 883 (Supplément, I 887). 
(B) General Bibliographies.

(a) Library Catalogues.

The official Catalogue of the British Museum, which is regularly posted, contains special divisions for "Periodical Publications" and "Academies." For the bibliographical section, see above, No. 2. Certain works of reference in the Reading Room and Galleries are indicated in separate catalogues.

5. Cardiff Free Library. Catalogue of Printed Literature in the Welsh Department (J. Ballinger and J. I. Jones), I 898 .

6. Dublin, Trinity College. Catalogus Librorum Impressorum qui in Bibliotheca Collegii ... Trinitatis adservantur. Dublin, I864.

7. Edinburgh, Faculty of Advocates. Catalogue of Printed Books in the Library of (by S. Halkett, completed by J. A. Hjaltalín), Edinburgh, I 863-1879.

8. London, British Museum. Subject Index of Modern Works added to the Library of the British Museum, I881-I910. 1902, etc.

9. - Guildhall Library. Catalogue of the, 1889.

10. - Law Society. Catalogue of the Library (F. Boose), 1891. Supplement (W. M. Sinclair), I 89I-I906.

II. LoNDON LiBrary. Subject Index of (C. T. Hagberg Wright), I 909 .

I Ia. London Library. Catalogue of (C. T. Hagberg Wright), in progress, IgO3, etc.

12. - Public Record Office. Catalogue of the Library of the, I902. Supplement, rgog.

13. - Royal Statistical Society. Catalogue of the Library of, Igo8.

14. - Society of Antiquaries. Printed Books in the Library of, I 887. Supplement, I887-99. 
15. London, University of. Catalogue of the Library, 1876. Accessions, I886, etc. (R. A. Rye).

16. Manchester, John Rylands Library. Catalogue of Printed Books and Manuscripts (E. Gordon Duff). Manchester, I899. Supplemented by Bulletin of the Rylands Library, 1903, etc.

17. The National Library of Wales. Bibliotheca Celtica: A register of publications relating to Wales and the Celtic Peoples and languages. Aberystwyth, 1910, etc.

(b) Current Bibliographies (Repertories).

18. Allgemeine Bibliographie. Leipzig, 1856, etc.

19. Cambridge University Library. Bulletin.

Cambridge, I886, etc.

20. English Catalogue of Books, 1835, etc.

21. London, British Museum. List of Accessions to the Reading Room, I9Io, etc.

22. Pagliaini, A. Catalogo Generale della Libreria Italiana, I847-1899. Milan, I901. Indice per Materie. Milan, I9ro.

23. Polybiblion, Révue Bibliographique Universelle (Société Bibliographique) Paris, I868, etc.

(c) Bibliographies of Periodicals.

See British Museum Library Catalogue under "Periodicals."

24. Bibl ographie der Deutschen Zeitschriften Litteratur, etc. Leipzig, I897, etc.

25. Jordell, D. Repertoire Bibliographique des principales Révues françaises. Paris, I 8981900.

26. Notes and Queries (General Index). 1856, etc. 27. Poole, W. F. Index to Periodical Literature, with supplement, I891-1902 (in progress).

28. Stead, W. T. Annual Index of Periodicals, I891, etc. 
(d) Bibliographies of Learned Societies.

29. Bibliographie générale des travaux historiques et archéologiques publiés par les Sociétés savantes de la France (R. de Lasteyrie and E. Lefèvre Pontalis). Paris, I888, etc.

30. Gomme, G. L. Index of Archæological Papers, 1665-1890. 1907.

31. - Annual Index of Archæological Papers, I891. (1892, etc.)

32. Minerva: Jahrbuch der Universitäten der (gelehrten) Welt. Strasburg, I89I, etc.

33. Washington, List of Doctoral Dissertations in Progress in the Carnegie Institute of. I897, etc.

34. Year-Book of Scientific and Learned Societies of Great Britain and Ireland, I884, etc.

See also British Museum Library Catalogue, under "Academies."

(e) Special Repertories of General Bibliograpby.

35. Martin, J. Bibliographical Catalogue of Privately Printed Books, I854.

36. Phillipps, T. Catalogue of Printed Books. Middle Hill, 1827 , etc.

37. The John Crerar Library: A list of Bibliographies of Special Subjects. Chicago, 1902.

\section{(C) Historical Bibliographies.}

The titles of some selected Bibliographies are given here, whilst other well-known works are omitted for reasons given in the Preface. These Bibliographies, however, must be supplemented by the bibliographical lists and the footnotes of certain works of reference; also by Periodical Publications. Some of these are mentioned in the subsequent sections referring to Auxiliary Studies and General Authorities, as well as in Parts II. and III., dealing with the Original Sources and their Literature. 
(a) Bibliographies of the Auxiliary Studies of History. Historical Method.

38. WYER, J. I. Bibliography of the Study and Teaching of History. (American Historical Association Annual Report, 1899, Vol. I., p. 589.)

Palaograpby and Diplomatzc.

39. Birch, W. de G., and Jenner, H. Early Drawings and Illuminations, 1879 .

40. Bourmont, A. DE. Paléographie et diplomatique. (Congrès bibliographique international, I888.) Paris, I889. Reprinted separately. Paris, I 888.

4I. Giry, A. Manuel de Diplomatique. Paris, I 894. [B.]

42. Grand, E. D. Cours de paléographie de la Faculté des Lettres de Montpellier, Leçon d'ouverture. (Revue des langues romanes, 4e ser., tom. iii., pp. 590-600.) Montpellier, 1890 .

43. Hessels, J. H. The Palæographical Publications of the last Twenty-five years, $1859-84$ (Academy, 20th Sept., 4th October, IIth Oct., I884).

44. Iнм, M. Lateinische Papyri. (Bibliothekswesen, xvi., pp. 341-57.) Leipzig, I 899.

45. Manchester, John Rylands Library. List of works on Greek and Latin Palæography and Diplomatic. (Bulletin of the Fobn Rylands Library, Vol. I., No. 2, p. 67, 1903-4.) Reprinted separately, I904.

46. Moore, M. F. Two Select Bibliographies of Mediæval Historical Study. I.-Bibliography of Palæography, etc. (London School of Economics). IgI2. 
47. Омоnт, H. Listes des recueils de facsimiles et des reproductions de manuscrits conservés à la Bibliothèque Nationale. (Revue des Bibliothèques.) Paris, 1903.

48. Pirenne, H. Sur l'état actuel des études de paléographie et de diplomatique. (Revue de l'instruction publique en Belgique, tom. xxix., 87-103.) Gand, I886.

49. Poupardin, R., and Prou, M. Liste des Recueils de Facsimiles des Chartes (Actes $d u$ Congrès International pour la reproduction des Manuscrits, etc., p. 217). Brussels, 1905.

50. Prou, M. Paléographie et diplomatique de I 888 à I 897 . (Congrès bibliographique international, I898, Vol. I., pp. 498 sq.) Paris, 1900.

5I. Rankin, J. T. An Index to Facsimiles Useful in the Study of Latin Palæography. (Brooklyn: Pratt Institute Monthly, I899. Vol. VIII., p. 39.)

52. WARNER, Sir G. F. Indices to Facsimiles of Manuscripts and Inscriptions. Series I. and II. (Palaograpbical Society), I90I.

A list of the chief palæographical publications during each year is appended to the Annual Report of the above Society, issued to its members.

Sigillograpby.

53. Bцоom, J. H. English Seals, 1906. [B.] See also No. 46.

54. London, South Kensington Museum. List of Books and Pamphlets in the National Art Library, illustrating Seals, I 886.

Numismatics.

55. Engel, A., And Serrure, R. Repertoire des Sources imprimées de la Numismatique française, I 887 , etc. [B.] 
56. London, South Kensington Museum. List of Books and Pamphlets in the National Art Library, on Coins and Medals, 1889.

See also No, 46.

Archaology.

57. Archrological Journal, Vols. I. to XXV., Index. 1878.

58. Archæologia, Vols. I. to L., Index (Edward Peacock and Mill Stephenson). I889.

59. Associated Architectural Societies, Index to

Reports and Papers, Vols. I.-VIII. I 867, etc.

60. British Archæological Association, General Index to the Journal of. Vols. I.-XXX., I 875 ; Vols. XXXI.-XLII., I 887 (by Walter de Gray Birch).

6r. Cambridge Antiquarian Society. List of Publications, I908 (in progress).

62. Eitelberger von Edelberg, R. Quellenschriften für Kunstgeschichte und Kunsttechnik des Mittelalters und der Renaissance. Vienna, I 871 , etc.

63. Guppy, H., and Guthrie, V. Classified Catalogue of Works on Architecture and the Allied Arts in the Municipal Libraries of Manchester and Salford. I909.

64. LASTEYRiE, R. DE, ETc. Bibliographie générale des travaux historiques et archéologiques publiés par les sociétés savantes de la France. Paris, I 888, etc.

65. London, South Kensington Museum. List of Works on Costume in the National Art Library, I88r.

66. Revue Archéologique. Table générale Alphabétique, Paris, 1844-1853. Table Décénnale (M. F. Delaunay), Paris, 1874. Table des Années, 1870-1890 (A. Bertrand and G. Perrot), Paris, 1893. 
67. Sturg1s, R. Catalogue of the Avery Architectural Library. $\mathbf{1} 895$.

68. Sturgis, R., and Krehbiel, H. E. Annotated Bibliography of Fine Art (Boston Library Burcau). Boston, 1897 .

Biograpby, Genealogy, and Heraldry.

69. Gundlach, O. Bibliotheca familiarum nobilium. Neustrelitz, I897.

70. London, Victoria and Albert Museum. Classed Catalogue of Printed Books, Heraldry. I90I.

71. Marshall, G. W. The Genealogist's Guide. 1903.

72. Oettinger, E. M. Bibliographie Biographique. Brussels, I 854 .

Geograpby and Topography.

73. Anderson, J. P. The Book of British Topography. I88I.

74. Chevalier, C. U. J. Topo-Bibliographie (Répertoire des Sources historiques du Moyen Age, Pt. II.). Paris, I 894-I903.

75. Daniell, W. V., and Nield, F. J. Manual of British Topography: A Catalogue of County and Local Histories, Pamphlets, Views, Drawings, Maps, etc. 1909.

76. Ordnance Survey (Board of Agriculture, etc.). Catalogue of 6 -in. and 25-in. Country Maps and Town Plans of England and Wales, and the Isle of Man; and of the I-in. and smaller scale Maps. 1909.

Sce also below (C) (e), the Subject Indexes of the British Museum (No. 8) and London (No. I1) Libraries, the catalogue of the Society of Antiquaries (London), and for Current and Periodical Bibliography, the British Museum Catalogues of

"Academies" and "Periodical Publications," the Index of Archeological Papers (No. 30), and the bibliographical lists published in certain learned Journals or Transactions. 
(b) Bibliographies of Universal History.

77. Herre, P. Quellenkunde zur Weltgeschichte. Leipzig, 1910.

For the current bibliography, see the Jahresberichie der Geschicheswissenschaft (No. 99), the Dewesche Zeisschrift fïr Geschicheseoissenschaft (No. 96), the Historiche Vierbeljahrschrift, and ocher publications mentioned in Sub-division (d).

(c) Bibliographies of the Middle Ages.

78. Chevalier, U. Répertoire des Sources historiques du Moyen Age. Paris, I894-1907.

79. Le Moyen Age: Paris, 1888 , etc. (1888-1894, monthly ; 1894, etc., bi-monthly.)

8o. Potthast, A. Bibliotheca historica medii acvi : Wegweiser durch die Geschichtswerke des europäischen Mittelalters bis 1500 . Berlin, I 896 .

(d) Bibliographics of National History.

England.

81. American Historical Review, New York. I 895 , etc.

82. Cannon, H. L. Reading References for English History. 1910.

83. English Historical Review, General Index to Articles and Reviews in (Vols. I.-XX., I 8861905). 1906.

84. Gross, Charles. The Sources and Literature of English History from the Earliest Times to about 1485 . 1900 .

Scotland.

85. TERry, C. S. A Catalogue of the Publications of Scottish Historical and kindred Clubs and Societies, etc. Glasgow, I909.

86. Terry, C. S. An Index to the Papers relating to Scotland, described or calendared in the Historical MSS. Commission's Reports. Glasgow, 1908 . 
Ircland.

87. KING, J. Irish Bibliography. I903, etc.

88. List of Works in the New York Public Library relating to Ireland, etc. New York, 1905.

Wales (See No. 17).

France.

89. Bibliothèque de l'Ecole des Chartes. Tables des Tomes XXI.-LX., I880-89. Suivie des Tables Générales Sommaires des Tomes L.-IX. Paris, I893.

90. Bibliographe Moderne. (Paris), 1897 , etc.

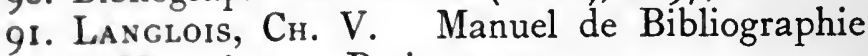
Historique. Paris, I90I-4.

92. Molinier, A. Les Sources de l'histoire de France. Paris, I90I, etc.

93. Monod, G. Bibliographie de l'histoire de France . . depuis les origines jusqu'en, I789. Paris, I 889.

94. Revue Historique, Tables Générales, I876I 900, etc. Paris, I88I, I887, I89I, I896, I901, I902.

\section{Germany.}

95. Dahlmann-Waitz. Quellenkunde der deutschen Geschichte. Leipzig, I906.

96. Deutsche Zeitschrift für Geschichtswissenschaft, I889-96; continued as Historische Vierteljahrschrift. Leipzig, I898, etc.

97. Dietrich, F. Bibliographie der deutschen Zeitschriften Litteratur. Leipzig, I897, etc. 98. Ebert, A. Allgemeine Geschichte der Litteratur des Mittelalters im Abendlande bis zum Beginne des XI. Jahrhunderts. Leipzig, 1889.

99. Jahresberichte der Geschichtswissenschaft. (Historische Gesellschaft. Berlin, I880, etc.) 
100. Lorenz, O. Deutschlands Geschichtsquellen im Mittelalter seit der Mittel des Dreizehnten Jahrhunderts. Berlin, 1886-7.

IOI. Meister, A. Grundriss der Geschichtswissenschaft zur Einführung in das Studium der deutschen Geschichte des Mittelalters und der Neuzeit. Leipzig, I906-8.

102. Oesterley, H. Wegweiser durch die Literatur der Urkundensammlungen. Berlin, 1885-6, etc.

103. Vildhaut, H. Handbuch der Quellenkunde zur deutschen Geschichte bis zum Ausgange der Staufer. Werl, I906.

104. Wattenbach, W., and Dümmler, E. Deutschlands Geschichtsquellen im Mittelalter bis zur Mitte des dreizehnten Jahrhunderts. Stuttgart and Berlin, 1904, etc.

105. Zeitschrift für Social und Wirthschaftsgeschichte. Leipzig, etc., I 893-1900.

Italy.

ı06. Bibliografia Periodica Romana. Roma, I9ı, etc. (Bollettino biografico.)

107. CAlvi, E. Bibliografia di Roma nel medio evo. Rome, I906.

108. Rivista Storica Italiana, 1884 , etc. Index (I884-I90I, etc). Turin, I904, etc.

Low Countries.

109. Bruyssel, E. van. Table Générale des notices concernant l'histoire de Belgique publiées dans les revues belges de 1830 à $\mathbf{1} 865$. Brussels, I 869 .

IIO. Fruin, R. (and others). Repertorium der Verhandelingen en Bijdragen betreffende de Geschiedenis des Vaterlands, etc. Leyden, 1863 , etc.

II Nijuoff, M. Bibliographie Systématique. The Hague, 1895 , etc. 
1 12. Petrt, L. D. Repertorium der Verhandelingen en Bijdragen betreffende de Geschiedenis des Vaderlands, in Tijdschriften en Mengelwerken tot op 1900 verschenen (Maatschappij der Nedirlandscbe Letterkunde). Leyden, I907.

113. Pirenne, H. Bibliographie de l'histoire de Belgique. Brussels, 1902.

114 . Les Archives Belges. Brussels, 1899, etc.

\section{Pininsular Kingdoms.}

115. Figaniere, J. C. DE. Bibliographia Historica Portugueza. Lisbon, I 850.

116. Pinto DE Sousa, J. C. Bibliotheca Historica de Portugal. Lisbon, I80I.

Scandinavian Kingdoms.

II6A. Dansk Historisk Forening; Historisk Tidsskrift. 1839 , etc.

117. Norsk Historisk Forening; Historisk Tidsskrift. Christiania, 187 I, etc.

I18. Svenska Historisk Föreningen; Historisk Tidsskrift. Stockholm, I88I, etc.

See also British Museum Catalogue under "Countries"; the Subject Index (J.K. Fortescue) under same; the London Library Subject Index under the same; and the Catalogue of the Bibliotheque Nationale, Paris (Section N.N.), Histoire de la Grande Bretagne.

(c) Bibliographies of Special Branches of Mediaval History (Political, Constitutional, Legal, Ecclesiastical, Nazil and Military, Economic and Social, and Local History).

Several extensive Bibliographies exist for such subjects as Ecclesiastical History (e.g., C. de Smedt, Introductio generalis ad historiam ecclesiasticam, etc., Ghent, 1876 ; E. Bratko, Wegweiser, etc., Gotha, 189o) and Law (E. Dramard, Bibliograpbic de la Bibliograpbie générale du Droit francais et étranger), whilst for Local History, besides the important works of Ottino and Fumagalli (No.328), Manzoni (Nos. 123- 
124), Gross (No. 121), Morris and Jordan (No. 125), almost every State, department, province, or county, now has its local bibliographer.'

Again, the pages of historical writers like W. Möller (Lebrbuch der Kirchengeschicbte), S. and B. Webb (No. 841), G. L. Gomme (No. 120), and G. Gavet (Sources des Institutions et du droit francais) are rich in references to the literature of local history. For Political and Constitutional History, reference may be made to the selected Bibliographies cited in this work, supplemented by the lists of authorities appended to works like Lavisse (Histoire de France), the Political History of England. (Longmans), and the Cambridge Mcdiceval History. The bibliographies of Naval and Military History are chiefly concerned with a later period, and no special repertories exist for the subject of Economic and Social History, though a good list of authorities will be found in Cunningham's Growth of English Industry (No. 829), and useful references in Ashley's Studies and Reviews and various authorities cited in Part III. of this work. The Current Bibliography of the subject must be supplied from various journals devoted to the study of the several branches of History in question, as well as from the Fabresbericbte (No. 99). For the study of Economic and Social History special reference may be made to the following periodicals, which are, however, chiefly concerned with a later period.

119. Borssonade, $\mathrm{P}$. Les études rélatives à l'histoire économique de la France au Moyen Âge (Revue de Synthèse bistorique). Paris, 1903 .

120. Goмme, G. L. The Literature of Local Institutions. 1886.

121. Gross, C. A Bibliography of British Municipal History. 1897.

1 For the Bibliography of Municipal Records ct. Notes and Queries, Series II (2), December, 3rd, 1910, etc. 
122. Gross, C. Town Records of Great Britain (American Historical Review, II., I9I-200). New York, I897.

123. Manzoni, L. Bibliografia degli Statute, Ordini e Leggi dei Municipii Italiani. Bologna, I 876-9.

124. - Bibliografia Storica Municipale. Bologna, I 892.

125. Morris, J. E., AND Jordan, H. E. Introduction to the Study of Local History and Antiquities. I9ro.

126. Stieda, W. Ueber die Quellen der Handelsstatistik im Mittelalter. 1902. (See No.323.) See also $\mathrm{C}(\mathrm{a})$.

\section{(f) Bibliograpbies of Special Historical Subjects.}

For particular works see above (B) (e) (Special Repertories) and (C) (a) (Auxiliary Studies). For the most part, however, the titles of works that are presumably of special value will be more conveniently obtained from the bibliographical lists appended to certain monographs. These are frequently published in the various "Academies." Under the modern conditions of historical study such isolated lists are of peculiar value. The following specimens of these special studies are only meant to be suggestive :-

127. British Museum. List of Books in the Reading Room, I9IO.

128. Camden Society. Catalogue of the first series of the Works of (H. Gough). I88I.

129. Сhetham Society. Index to Remains Historical and Literary, published by. Vols. I.-XXX., I863; Vols. XXXI.-CXIV., I893, Manchester.

130. Davenport, F. G. A classified list of Printed Materials for English Manorial and Agrarian History. Boston, I894. See also No. I38. 
131. Delisle, Leopold. Bibliographie des Travaux de (by P. Lacombe). Paris, 1902-II.

132. Domesday, Bibliography of (see P. E. Dove, Domesday Studies, Vol. II.). 1891.

133. Historical Association, Leaflets issued by the, I9ro, etc.

134. Jacob, J., and Wolf, L. Bibliotheca AngloJudaica : A bibliographical guide to AngloJewish History. 1888. See also No. 143.

135. Karslake, F. Notes from Sotheby's, being a compilation from Catalogues of Book Sales, 1885-1909. 1909.

136. MÉly, F. DE, ANd Bishop, E. Bibliographie générale des inventaires imprimés. Paris, I 892-5.

137. Maitland, F. W. Two Lectures and a Bibliography (A. L. Smith). 1908.

138. Moore, M. F. Two Select Bibliographies of Mediæval Historical Study. 1912.

See also No. 45.

139. Philipps, E. A List of Printed Churchwardens' Accounts (English Historical Revicw, 1901).

140. Public Record Office. List of Topographical Works relating to Great Britain and Ireland. P. P., 1907.

141. H.M. Stationery Office. Catalogue of English, Scottish, and Irish Record Publications, etc. 1911 .

For Record Publications, see also C. Gross: Sources and Lizerature, Appendix D.

142. RyE, R. A. The Libraries of London. 1910.

143. Sснwaв, M. Répertoire des articles relatifs à l'histoire et à la littérature juives parus dans les périodiques (1783-1898). Paris, 1899. See also No. 34 .

144. Shaw, W. A. Bibliography of the Historical Works of Dr. Creighton, Dr. Stubbs, Dr. S. R. Gardiner and Lord Acton (Royal Historical Socicty). 1903. 
145. Stammhammer, J. Bibliographie der Finanzwissenschaft. Jena, I903.

146. Thомаs, F. S. Notes of Materials for the History of Public Departments. 1846. Appendices E, F, G.

147. Thомas, D. L. Bibliographical list of works relating to Welsh Agriculture and Land Tenure. (Royal Commission on Land in $W$ ales, etc., Appendix B.) 1896.

\section{Division II.-INVENTORIES OF RECORDS AND STATE ARCHIVES.}

As these instruments represent the means of access to texts of historical documents in an unpublished form, they are now rightly included in the scope of Historical Bibliography. Although differing widely in respect of form, method of construction, and terminology in the case of different nations, and even of different institutions, an inventory, list, index, calendar repertory, catalogue (or by whatever title it is known), whether in type or manuscript, whether detailed or summary, conveys some indication of the nature or value of individual MSS. that have not yet been calendared or printed in full.

A collective Catalogue of inventories for every country is at the present moment one of the great needs of historical students. Partial catalogues of this nature have been compiled for Europe (No. 196) and individual countries; but the difficulty of posting frequent additions and alterations has hitherto proved insuperable. A few general remarks may be useful as to the condition of the archives of this and other countries.

England.

The State Archives here are centralised to a degree exceeded only in the sister-kingdoms of Scotland and Ircland. An official Bibliography of Inventories 
is available in the shape of a List of Lists displayed in the Search Rooms (which is now posted up to date) and printed in the Deputy-Keeper's 24th (1862) and 4 Ist (1879) Reports; but useful information will be found in Scargill-Bird's Guide, and a catalogue of the Lists and Indexes and other Inventories on sale is issued by H.M. Stationery Office (No. I4I). As to the above-mentioned official series of Lists and Indexes, see Atheneum, 6th August and Ist October, 1910. The titles of a few useful publications are given below :-

148. Ayloffe, J. Calendars of the Ancient Charters and of the Welsh and Scottish Rolls. I774.

149. Cooper, C. P. An account of the most important Public Records of Great Britain and the publications of the Record Commission. 1832 .

150. HALL, H. Formula Book of English Official Historical Documents. Parts I and 2. Cambridge, 1908-1909.

151. - Studies in English Official Historical Documents. Cambridge, 1908.

152. Hardy, W. J. History of the Rolls House and Chapel (reprinted from Middlesex and Hertfordshire Notes and Queries for 1896, p. 49). I 896.

153. London, Public Record Office. Lists and Indexes (Nos. I., IV., V., VI., VIII., IX., XI., XII., XIV., XV., XVI., XVII., XXII., XXV., XXVII., XXXII.). I892, etc.

154. - Reports of the Deputy-Keeper of the. Index to the Printed Reports of Sir Francis Palgrave (1840-61), I865; Index to the Printed Reports of Sir Thomas Duffus Hardy (1862$78)$, I880.

Many of the Inventories in the earlier Reports are still valuable-e.g., D.K., 2nd Report, App. ii., 136-189, and $3^{\text {rd }}$ Report, App. ii., 3-104. See also 24th Report, List of Inventories and Calendars, 1863 ; 4 ist Report, List of Inventories, Calendars and Catalogues. 1880. 
155. Palgrave, Sir F. The Antient Kalendars and Inventories of the Treasury of His Majesty's Exchequer. Record Commission. 1836.

156. Records, Public. Reports from the Select Committee appointed to inquire into the state of the Public Records. 1800 .

157. Records, Commission on. First and Second Reports, I800-1819. (Parl.Papers, Vol.XX.), I8I9.

158. Commission on. General Report from the Commissioners, 1831-7. (Parl. Papers, Vol. XXXIV.), I 837 .

I 59. RyE, W. Records and Record Searching. I897. 160. Scargill-Bird, S. R. Guide to the Public Records. 2nd ed., r896; 3rd ed., 1908.

16r. Tномas, F. S. Handbook to the Public Records. 1853 .

\section{SCOTLAND.}

Although no series of Inventories has been published in the official Reports of the Deputy-Keeper, an excellent Guide has been published and references to Scottish documents will be found in Scargill-Bird's Guide. Several ancient MS. inventories are preserved at the Register House, Edinburgh.

162. Edinburgh, General Register House. Annual Reports of the Deputy-Clerk Register of Scotland, I 807-68.

163. Livingstone, M. Guide to the Public Records of Scotland. Edinburgh, 1905.

164. Scottish Historical Clubs and Societies. A Catalogue of the Publications of ; and of the volumes relative to Scottish History issued by H.M. Stationcry Office, 1780-1908 (C. S. Terry). Glasgow, 1909. 


\section{IRELAND.}

Inventories have been printed in the DeputyKeeper's Reports since 1869 , but without any definite method. There is no official Guide, but references to the Irish documents in the Public Record Office will be found in Scargill-Bird's Guide, and some descriptions of individual records is given by J. T. Gilbert. Account of Facsimiles of National MSS. of Ireland (1884).

165. Dublin, Public Record Office. Reports of the Deputy-Keeper of the Public Records in Ireland. i 869 , etc.

\section{Wales.}

The Welsh Records having been transferred to London, such inventories as exist will be found in the Reports of the Deputy-Keeper (Chester and Flint chiefly). A list of the Chester and Welsh Records is in the Press. Reference may also be made to the articles by R. A. Roberts (No. 167), H. Hall (No. 166), and E. A. Lewis, in Transactions Royal Hist. Soc., N.S., Vol. XVII.

166. Hall, Hubert. The foreign aspect of the Welsh Records. $\quad$-Cymmrodor, XXII. London, I9I0.

167. Roberts, R. A. The Public Records relating to Wales. Soc. of Cymmrodorion, $r^{2}$-Cymmrodor X., 157-206. London, 1890.

FRANCE.

There is no complete or up-to-date Bibliography of the Archives Nationales in Paris or of the Archives Départementales in the Provinces. The literature of these archives is cited in the manuals of Langlois and Stein (No. 174), and Langlois (No. 91); also by E. Lelong in Répertoire Général du droit franfais (1889). Reference should also be made to H. Bordier's Les Archives de la France (1855).

C 
In periodical literature valuable indications will be found in the Bibliotheque de l'Ecole des Chartes (No. 177), the Révue internationale des Archives (No. 180), and the Annuaire des Arcbives, etc. (1886, etc.). A report by $\mathrm{L}$. Mirot on the inventories printed from I 888-1898 was published in 1899. The state of the inventories of the Departmental Archives is described in several works (Nos. r68-I70). For the literature relating to French history in foreign Archives, reference should be made to the works of Bréquigny and Delpit and the Archives des Missions (I 855 sq.)

In addition to the few select inventories given below, many others may be consulted by students as card catalogues (" en fiches"). The "Index Chronologique" of Teulet's work (No. I69) and the "Tableau" of the Etat Sommaire (No. I68) will be found useful.

For the literature of the Local Records (Archives Municipales, etc.) and Private Collections (Archives Diverses) and Libraries, see the works of Langlois and Langlois and Stein.

168. Archives Nationales. Etat Sommaire par séries. Paris, I 890.

169. L-Layettes du Trésor des Chartes (A. Teulet). Paris, I 863-1902.

170. - Catalogue Sommaire du Musée des (J. Guiffrey). Paris, I893.

171. Archives départementales, Communales et hospitalieres antérieures à 1790 : Collection des Inventaires Sommaires des. Paris, 1862.

172. - Tableau Général numérique par fonds des, antérieures à I 790 . Paris, 1848 .

173. —Etat Général par fonds des. Paris, 1904.

The Student must bear in mind that the bulk of these Archives are for the 17 th and 18 th centuries. The following publications may be recommended:-Archives anciennes de la ville de Saint-Quentin, ed. G. Lemaire (1888); Archives départementales du Calvados (1834); Archives municipales d'Agen (1876); Archives administratives de la ville de Reims (1839-53); Inventaire des archives de Narbonne (1870-7). 
174. Langlois, C. V., and Stein, H. Les Archives de l'Histoire de France. Paris, I 891-3.

175. Pannier, L. Etat des Inventaires Sommaires, in Bibliothéque de l'École des Chartis. T. xxxvi., xxxvii. Paris, 1875.

176. Annuaire des Bibliothèques et des Archives. Paris, 1888 , etc.

177. Bibliothèque de l'Ecole des Chartes. Paris, 1839, etc.

178. Bulletin des Bibliothèques et des Archives. Paris, $188_{4}$, ctc.

179. Bulletin des Comités des travaux historiques, etc. Paris, I899, etc.

180. Revue internationale des Archives des Bibliothèques et des Musées. Paris, I 895-97.

\section{Belgium.}

The Archives having received the same scientific attention as in France, the publication of inventories has not been neglected. Two official series have been constituted: (I) for the Archives du Royaume, (2) for the Dépôts in the Provinces. Several important Inventaires Sommaires have already appeared in both series. Besides these there are numerous earlier publications by L. P. Gachard and other archivists, which are described in the Archives de l'bistoire de France (Langlois and Stein) as well as in the Bibliography of M. Pirenne (No. II3) and in the short notices of the Belgian archives by $\mathrm{E}$. Laloire in the Annuaire de la Belgique scientifique, etc. (1907), and J. Cuvelier (Le Rôle des Archives, I9I I).

An attempt was made to describe the provincial archives in L. P. Gachard's Table Synoptique (1876). Many useful descriptions will be found in the Revue des Bibliotheques et des Archives de Belgique (No. I89). 
18I. Inventaire des Inventaires de la IIe section des Archives Générales du Royaume (J. Cuvelier) Brussels, 1904.

182. Inventaire analytique des archives des commanderies belges de l'Ordre de Saint-Jean de Jérusalem ou de Malte (XIIe-XIIIe siècle). (L. Devillers) Mons, 1876.

183. Inventaires sommaires des Archives des Anciens Gouvernements des Pays Bas. Brussels, 1905 , etc.

I84. Inventaire des Archives de la Belgique (L. P. Gachard). Brussels, I 837-90.

185. Inventaire des cartulaires conservés dans les dépôts des archives de l'Etat en Belgique (L. P. Gachard). Commission Royale d'Histoire. Brussels, 1895.

I 86. Gachard, L. P. Notices des comptes en rouleaux conservés aux archives générales, XIIIe-XVe siècle. Commn. Royale d'Histoire, sér. 2, t. vi. Brussels.

187. - Tableau synoptique des archives de l'Etat dans les provinces. (Moniteur belge, July Ioth, I 876.) Brussels.

188. Laloire, E., and Lefevre, E. Tableau synoptique des Archives Générales du royaume à Bruxelles. Revue des Bibliothèques et des Archives de Belgique. Brussels, I903.

189. Revue des Bibliothèques et des Archives de Belgique. Brussels, I903, etc.

\section{Netherlands.}

The best Guides to the Archives, Library, and other Collections of the Netherlands will be found in the Reports (Verslagen) of the old Rijks Archieven (1878, etc.) ; the Proceedings (Notulen) of the Society of 
Dutch Archivists (1890, etc.); the Journal (Nederlandsch Archicuenblad) of the same Society (189I, etc.); and the Survey (Overzicht) of the various Inventories, etc., relating to the Dutch Archives. A useful conspectus of these Archives giving the state of the Inventories, etc., up to the year 1905, will be found in the Repertorium, edited by Major-General F. de Bas for the Krijgsgeschiedkundig Archief van den Generalen Staf, and also in the Tabellarisch Overzicht, appended to the Proceedings of the Congress of Dutch Archivists in 1898-1899.

No official report on the Dutch Archives has been published by the English Government. For the contents of Foreign Archives relating to the Netherlands, the official Reports of P. J. Blok, H. Brugmans, and others, refer almost exclusively to the postmedirval period. Some valuable materials are described in the publications of the "Commission of Advice for national historical publications" (the Hague, 1894, etc.), and in the Bulletins of the Commission royale d'histoire.

190. Muller, S. Manuel pour le classement et la description des archives. [French Trsl.] Hague, 1910.

191. De Gids. Amsterdam, I837, etc.

See especially, the years 1891 and 1893 .

192. Nederlandsch Archievenblad. Haarlem, 1892, etc.

Germany, Austria-Hungary, and Switzerland.

Comparatively few printed inventories have been published in these countries. Some assistance may be derived from the following works and periodicals : G. Holtzinger, Catechismus der Registratur und Archivkunde; F. von Löher, Archivlebre, and Burkhardt's Hand-und-Adress-Buch der Deutschen Archive (1887).

These works are, however, to some extent obsolete, and are now superseded by two brief but useful returns 
contained in F. Hettler's Archivalische Bibliographie (Halle, 1908) and the same author's Archivalischer Almanach (I9IO-I I), and Adress-Buch der Wicbtigsten bistorischen Archive Europas; works which, though unsystematic and incomplete, are of considerable service. Reference should also be made to the following periodicals : Archivalische Zeitschrift (1875, etc.), Mitteilungen des Instituts für oesterreichiscbe gescbichtsforschung, Zeitschrift für die Gescbicbte des Oberrbeins, Mitteilungen der K. Preussischen Archivverwaltung the Mitteilungen der (Archiv) Sektion der $K$. K. Zentral-Kommission für Kunst, etc., in Wien.

There are a few Guides to the archives of individual states, e.g., 'Th. Ilger's Rheinisches Archiv.

The archives of Alsace-Lorraine are arranged and catalogued to a large extent on the French system.

Much information as to the Germanic archives can be obtained from the reports of foreign archive-missions. ${ }^{1}$ An official series of Inventare Oesterreichischer Staatlicber Archive is now in course of publication at Vienna.

Attempts have been made, chiefly in Germany, to prepare a collective bibliography of Archive literature at least every ten years, and much has been done by the Congresses and professional periodicals of Archivists in this connection.

193. Abert, J. F. Die archivalische Literatur der letzen acht jahre (1898-I906). Archivalische Zeitschrift, N.F. xiv. (1907), Seite 85-188.

194. Bӧнм, C. E. von. Die Handschriften des Kaiserlichen und Königlichen Haus-Hof-und Staats-Archivs. Vienna, I 873.

195. Burkhardt, C. A. H. Hand-und Adress-Buch der Deutschen Archive im Gebiete des Deutschen Reiches,Luxemburgs, OesterreichUngarns, der russischen Ostseeprovinzen und der deutschen Schweiz. Leipzig, 1887.

1 The latest of these is issued by the Historical Department of the Carnegie Institution at Washington. 
196. Hetrler, A. Archivalische Almanach. I9IO. 197. - Archivalische Bibliographie. 1908.

198. - Adress-Buch der wichtigsten historischen Archive Europas.

199. - Jahrbuch der deutschen historischen Kommissionen, Institute und Vereine, etc. Halle (Saale) 1904-1909.

200. Löher, F. von. Archivlehre. Paderborn, 1890. See p. 179 for the later literature of Archives. 201. Müller, J. Die wissenschaftlichen Vereine und Gesellschaften Deutschlands. 1905.

202. Archivalische Zeitschrift Stuttgart, 1876-88. (Neue Folge, Munich, I890, etc.) 203. Hansische Pfingstblätter. I905, etc. 204. Hansische Geschichtsblätter. Leipzig, 1872, etc. 205. Inventare Hansischer Archive des 16 Jahrhunderts (K. Höhlbaum and $H$. Keussen). Leipzig, I 896, 1903.

206. Inventare Oesterreichischer Staatlicher Archive. Vienna, 1909, etc.

207. Mitteilungen der Königlich preussischen Archivverwaltung. Leipzig, 1900, etc.

208. Mitteilungen der III. (Archiv) Sektion der K. K. Central-kommission für Kunst und-historische Denkmäler in Wien. Vienna, 1888 , etc.

209. Inventare Schweizerischer Archive. Bern, 1895, etc.

\section{ITALY.}

For the Vatican archives there is an extensive European literature as special researches have been published by several Governments and private agencies. See G. Brom, Guide aux Arcbives du Vatican (1910); the Reports, Transcripts and Calendars published by or preserved in the Public Record Office, London; and the Reports issued by French, Dutch, and American 
historical departments. No general inventory has yet been prepared.

The best current bibliography for the Italian State Archives (Archivio di Stato) is to be found in periodicals like the Archivio Storico Italiano and the Rivista de Archivos, etc. (1871, etc.), the Archivio della Socicta Romana di Storia patria, the Archivio Storico Lombardo, etc. There are many good inventories of State Archives, particularly that of Lucca (No. 2I 4). For the Venetian and Milanese Archives the Calendars (Rolls Series) and Transcripts (Public Record Office) should be noted. Much information is also contained in the "Archives des Missions" of other nations. A fairly full bibliography of the Archivi di Stato is given in Hettler's Almanach (No. 196). Printed inventories exist for most of these collections. Several German and other foreign scholars have published descriptions of the Italian archives, though scarcely from an economic point of view.

210. Archivalia in Italië belangrijk voor de geschiedenis van Nederland. (Brom, G.) Rijks Geschiedkundige Publicatiën. 1908-9.

211. Archivo di Stato: Inventario cronologico sistematico dei registri angioini conservati nell' Archivio di Stato in Napoli (B. Capasso). Naples, 1894 .

212. Bibliothèque des Écoles Françaises d'Athènes et de Rome. Paris, I877, etc.

213. Gachard, L. P. Les Archives du Vatican. Brussels, I 874 .

214. Inventario del R. Archivio di Stato in Lucca. Florence, I 872-I 888.

215. I Capitoli del Commune di Firenze. Inventario e Regesto. Florence, 1866-93. Documenti degli Archivi Toscani.)

216. L'Ordinamento delle Carte degli Archivi di Stato Italiano; Manuale Storico Archivistico. Ministero dell Interno. Roma, I910. 
217. Tadde1, P. L'Archivista, Manuale teorico
pratico. Milan, 1906.

Peninsular Kingdoms (Spain and Portugal.).

Inventories of the Spanish royal archives have only been partially printed, and chiefly in periodical publications, such as those mentioned below (Nos. 218-221). Reference may also be made to the following works : M. Alcubilla, Diccionario de Administracion española; R. Altamira, De Historia y Arte (1898) (No. 218). Descriptions of the Archives will also be found in the Archives des Missions (1865-I893), the Bibliotbeique de l'Ecole des Chartes (1884-1890), and the Revue Internationale des Archives (1895-7). Other indications will be found in the proceedings of the Royal Academies and learned societies of both countries. There is a good printed description of the archives at Lisbon (No. 219), and some ancient inventories of the same collection.

Catalogues of many libraries, churches, academies, etc., which possess historical MSS. have been printed. Some of these have been described in foreign Guides. For Portugal, some valuable manuscripts exist in the Record Office and a catalogue, by F. F. Figanière, of Portuguese MSS. in the British Museum (1853) is well known. For the MSS. on both sides, see also V. M. Shillington, Commercial Relations between England and Portugal (Bibliography) (2066).

2i8. Altamira y Crevea, R. De Historia y Arte. Madrid, 1898.

219. D'Azeredo, P. A., and Baiño, A. O. Archivo da Torre do Tombo. Sua historia, corpos, etc., e organização. Lisbon, 1905 .

220. Revista de Archivos Bibliothecas y Muscos Madrid, 1871-8. (Continued as Boletin de Archivos, etc., 1896; continued as Revista de Archivos, etc., I897, etc.) 
221. Boletim das Bibliothecas e Archivos naciones. Coimbra, r902, etc.

\section{Scandinavian Kingdoms (Denmark, Norway, SWEDEN).}

These countries have been chiefly concerned with their own national histories, and, therefore, descriptions of their archives are found in native works, chiefly of a periodical character. These include, for Denmark, the Meddelelser fra det danske Rigsarkiv (1906, etc.) ; for Norway, the Meddelelser fra det Norske Rigsarcbiv (1870-1903); for Sweden, the Meddelanden fran svenska Riksarkivet (1877, etc.). Other accounts will, however, be found in German and other foreign journals dealing with archive subjects, though these are mostly for the post-mediæval period, and the same remark applies to the Reports on Danish and Swedish archives in the Deputy-Keeper's $43^{\text {rd }}$ and $45^{\text {th Reports. }}$

222. Report on the Royal Archives of Denmark (by W. D. Macray). Deputy-Keeper's Report, XLV., App. II., Pt. I. 1885.

223. Meddelelser fra det. Danske Rigsarkiv. Copenhagen, 1906, etc.

224. Meddelelser fra det Norske Rigsarchiv. Christiania, I870-1903.

225. Report on Libraries in Sweden (by W. D. Macray) ; Report on Records of Sweden (by W. H. Bliss). Deputy-Keeper's Report, XLIII., App. II., pts. I and 2. 1882.

226. Meddelanden frản Svenska Riksarkivet. Stockholm, 1877 , etc.

227. Styffe, C. G. Bidrag till Skandinaviens Historia ur utlàndska arkiver. Stockholm, 1859-70. 


\section{Division III. - INVENTORIES OF LOCAL RECORDS, PROVINCIAL ARCHIVES AND OTHER MUNI- MENTS; CATALOGUES OF LIBRARIES AND PRIVATE COLLECTIONS OF MSS.}

In England, as abroad, no sharp distinction is made in the production of inventories of State archives by official or private enterprise. Similarly, inventories of local records or archives and catalogues of libraries and collections are everywhere produced by official or private agencies. By degrees, however, the practice of dealing with records or archives by official methods is becoming fixed. At the same time the archivist is still in request for compiling lists or catalogues of private collections. It is to be noted, however, that abroad the official influence of the various Commissions for publications is more far-reaching than that of our own Historical Manuscript Commission. Again, the respective conditions differ in another way-that is to say, we in England find practically all the local muniments and family papers still in the possession of ecclesiastical and other corporations or of individuals, whereas abroad a very large proportion of these local documents has reverted or is being handed over (like the Notarial Archives) to the State for preservation in provincial archives. Therefore we must have recourse to the official inventories of these archives.

Again, it should be noted that in England besides the publications of archives or commissions, many inventories have been prepared by the private enterprise of various corporations, learned societies, and private owners or collectors, and that, owing to the unfortunate instability of many private collections, the Catalogues of Sales should not be neglected as a source of information.

By careful examination and analysis much information may be derived from the Reports of the Historical 
Manuscripts Commission (Index in 17 th Report), Hardy's Catalogue (No. 255), the Report of the Committee on Local Records (1902), and the Guide to the Victoria County History.

The Catalogues of the great libraries are incomplete, and there is a general lack of co-ordination between official and private sources. The "Class Catalogue," placed in the Manuscript Department of the British Muscum (as in other libraries, especially abroad) will be indispensable; so also will be such Guides as Mr. Gray's recent Index to the Cole MSS. in the British Museum.

To some extent information as to the inventories or catalogues is afforded by Historical Bibliographies, like that of C. Gross (No. 84). In a few cases, several catalogues have been compiled for a single locality. Finally, assistance may be obtained from the published researches of local antiquaries or historical students.

In the case of the Sister-Kingdoms we receive far less help from recognised sources of information. For Scotland, there is Gross's Bibliography of Municipal History (No. I2I) and Professor Sandford Terry's valuable inventory of the publications of the $S$ cottish Historical Clubs (No. 85) and the same writer's Index to Papers relating to Scotland in the Reports of the Historical Manuscripts Commission (No 86). The Report of the Committee on Local Records (I902) is also of considerable value for this subject. For Irish local records and MSS. the same Report is available, and to this may be added the Reports of the Historical Manuscripts Commission and such works as O'Curry's Manuscript Materials of Irish History (No. 299).

Wales, unfortunate in the matter of the national records, has fared better in respect of the description of literary manuscripts, with such works as J. G. Evans's Reports on Welsh MSS. (for the Historical 
MSS. Commission), and E. Owen's Catalogue of Welsh MSS. in the British Muscum (No. 300).

In respect of Foreign sources derived from municipai or communal archives and private collections there is some disparity between the materials available in the case of certain States. At the same time, in such wellequipped countries as France, Belgium, Holland, etc., there is a considerable descriptive literature for these unofficial archives as well as many printed inventories. Moreover, whereas in England it is still the exception to find such collections adequately arranged and catalogued by means of a manuscript list of titles, such elementary dispositions are practically universal in all other large States. The literature above mentioned is too extensive for detailed notice here, but reference may be made to such works as Langlois and Stein (op.cit.), and Molinier, Sources de l' Histoire de France. At the same time it should be noted that the distinction between "Archives" and "Libraries" in these countries is a rather fine one, and, therefore, reference should be made to both headings of the present work. Finally, some assistance is rendered in respect of methods of research, by handbooks or essays, such as Langlois and Seignobos (No. 363), and Guides to the sources such as Oesterley's Wegweiser (No. 322).

It should be noted that, in many cases, an ambitious Calendar takes the place of the humble but more useful list, as in the case of several of the descriptions of municipal records. Special compilations, such as a List of Cartularies (No. 28I), are of great value.

In respect of the following titles of lists or catalogues of Local Records, etc., it must be clearly understood that these are only given as specimens, and that the selection made is not in any way exhaustive. 
ENGLAND.

228. Barnstaple Records (J. R. Chanter and T. Wainwright). Barnstaple, I900.

229. Bedford, Schedule of the Ancient Charters and Muniments of the Borough of. Bedford, 1895 .

230. Berkeley Castle, Descriptive Catalogue of the Charters and Muniments (J. H. Jeayes). I 892.

23I. The Berkeley Manuscripts (J. Maclean) Bristol and Gloucestershire Archeological Society. Gloucester, I 883, I885.

232. Bristol, Calendar of Charters of the City and County of. Bristol, I909.

23j. Brooke, Thomas. Catalogue of Manuscripts and Printed Books at Armitage Bridge House. I89I.

234. Cambridge: List of the Documents in the University Registry, I 266-I 544 (H. R. Luard) Cambridge Antiquarian Soc. 1876.

235. - Catalogue of the Manuscripts preserved in the Library of the University of. 1856-64.

236. Corpus Christi College: A Descriptive Catalogue of the Manuscripts in the Library of (M. R. James). 1909, etc.

237. - Gonville and Caius: Descriptive Catalogue of the Manuscripts in the Library of (M. R. James). $\quad$ I907.

238. - Fitzwilliam Museum : A Descriptive Catalogue of the Manuscripts in (M. R. James). 1895.

239. - Jesus College: A Descriptive Catalogue of the Manuscripts in the Library of (M. R. James). 1895 .

240. - King's College: Descriptive Catalogue of the Manuscripts, other than Oriental, in the Library of (M. R. James). I895.

241. Magdalene College: Catalogue of Manuscripts in the Library of (M. R. James). 1909. 
242. Cambridge, Pembroke College: A Descriptive Catalogue of the Manuscripts in the Library of (M. R. James). 1905.

243. - Peterhouse: A Descriptive Catalogue of the Manuscripts in the Library of (M. R. James). 1899.

244. Sidney Sussex College: A Descriptive Catalogue of the Manuscripts in the Library of (M. R. James). I 895.

245. - Trinity College: The Western Manuscripts in the Library of (M. R. James). 1900-4.

246. - Trinity Hall: Descriptive Catalogue of the Manuscripts in the Library of (M. R. James). 1907.

247. Chipping Wycombe, Charters relating to the Borough of. 1817 .

248. Colchester, The Charters and Letters Patent granted to the Borough of. Colchester, 1904.

249. Derbyshire Charters, Descriptive Catalogue of (J. H. Jeayes). 1906.

250. Dugdale, W. Monasticon Anglicanum. 1846. 251. Edwards, Edward. Libraries and Founders of Libraries. 1865 .

252. Ely, A Calendar of the Episcopal Records in the Muniment Room of the Palace (A. Gibbons). I89I.

253. Eton College, Catalogue of Manuscripts in the Library of (M. R. James). 1895.

254. Gloucester, Calendar of the Records of the Corporation of (W. H. Stevenson). I 893.

255. Hardy, T. D. Descriptive Catalogue of Manuscripts relating to the History of Great Britain and Ireland. 1862-77.

To 1327 only. The continuation by C. T. Martin was suspended in 1890 .

256. Historical Manuscripts Commission. Reports XVI. and XVII. List of Reports issued. 1904 and 1907. 
257. Ipswich, Calendar of Wills at [I444-1600] (F. A. Crisp). 1895 .

258. KinG's LyNn, Report on the Deeds and Records of (H. Harrod). I 874 .

259. Leicester, Index to the Ancient Manuscripts of the Borough of (J. C. Jeaffreson). 1878.

260. Records of the Borough (M. Bateson). 1899 , etc.

261. Lichfield, Catalogue of the Muniments, etc., of the Dean and Chapter of (J. C. Cox). William Salt Archaological Soc. Collections, VI., pt. 2, I 886.

262. Lincoln, Catalogue of the Royal Charters and other Documents, and list of Books belonging to the Corporation of (W. de G. Birch). 1906.

See also Lincolnshire $N$. and $Q$.

263. London: Society of Antiquaries, Catalogue of Manuscripts in the Library of the. I8I6, etc. 264. London: British Museum, Catalogue of Additional Manuscripts. I 828, etc.

265. - Catalogue of the Arundel and Burney Manuscripts. $1834-40$.

266. - Catalogue of Manuscripts in the Cottonian Library. 1802.

267. - Catalogue of Harleian Manuscripts. I 808-I 2.

268. — Catalogue of the Stowe Manuscripts. 1895-1 896.

269. - Catalogue of Manuscripts of Maps, Charts, and Plans, and of the Topographical Drawings, I 844 , etc.

270. - -Guide to the Manuscripts, Autographs, Charters, Seals, Illuminations and Bindings exhibited in the Department of Manuscripts and in the Grenville Library. 1906.

271. - Index to the Charters and Rolls in the Department of Manuscripts (H. J. Ellis and F. B. Bickley). 1900. 
272. London, Lambeth Palace, The Manuscripts in the Library at (M. R. James). 1900. (Cambridge Antiquarian Socicty publications, Vol. X.)

273. Manorial Society. Lists of Manor Court Rolls in Private Hands. London, 1907, etc.

274. Oxford: All Souls' College, Catalogue of the Archives in the Muniment Rooms (C. T. Martin). 1877.

275. - All Souls' College, Catalogue of Manuscripts in the Library (H. O. Coxe). 1842.

276. Bodleian Library, Catalogue of Charters and Rolls (H. O. Coxe and W. H. Turner). 1878.

277. Bodleian Library, Summary Catalogue of the Western Manuscripts (F. Madan). I895.

278. Catalogus Codicum MSS. qui in Collegiis Aulisque Oxoniensibus hodie adservantur (H. O. Coxe). 1852.

279. Christ Church, Catalogus Codicum MSS. qui in Bibliotheca Aedis Christi apud Oxonienses adservantur (G. W. Kitchin). Oxford, 1867. 280. Phillipps, T. Catalogus Librorum Manuscriptorum in Bibliotheca Thomae Phillipps. I 836-7.

281. - Index to Cartularies now or formerly existing since the dissolution of the Monasteries (Middle Hill Press). 1839.

See also Collectanea Topographica, etc. (No. 655).

282. - Catalogue des manuscrits de la collection Phillipps (H. Omont). Paris, 1909.

283. Reading, Diary of the Corporation of (J. M. Guilding). 1892 , etc.

Vol. I. contains a Schedule of Records.

284. Records (Local), Report of the Committee appointed to inquire as to the existing arrangements for the collection and custody of : with Appendices (CD. I335 and CD. 1333). 1902. 
285. Robertsbridge, Charters and Documents relating to the Abbey of, preserved at Penshurst. 1873 .

286. Sims, R. A Manual for the Genealogist, Topographer, Antiquary, etc. I86I.

286A. Shrewsbury Borough Records, Calendar of the. Shrewsbury, 1896 .

287. Sudbury, Calendar of the Muniments of the Borough of (E. Stokes and L. Redstone). Suffolk Institute of Archaology, Vol. XIII., pt. 3, p. 259. Bury St. Edmunds, 1907.

288. Suffolk, County of. . . - materials for the

History of Suffolk . . (W. A. Copinger). I904, etc.

289. Tanner, T. Notitia Monastica. 1787.

290. Walsall, Calendar of Deeds and Documents belonging to the Corporation of (R. Sims). I 882.

291. Westminster Abbey, Catalogue of Manuscripts in (J. A. Robinson and M. R. James). Igog.

292. Winchester (Bishopric of). Reports on the Muniments of, preserved at Winchester (C. Deedes). Winchester, I9I2.

293. Weymouth and Melcombe Regis, Descriptive Catalogue of Documents of the Borough of [1252-I800] (H. J. Moule). Weymouth, I883. 294. Worcester, Catalogue of MSS. in the Chapter Library of. Worcestershire Hist. Soc. 1906. 295. Yarmouth, Repertory of Deeds and Documents relating to the Borough of. (Printed by order of the Town Council). Yarmouth, 1855.

\section{Scotland.}

296. Scotland, An Index to the Papers relating to, described or calendared in the Historical MSS. Commission's Reports (C. S. Terry). Glasgow, 1908. 
297. Scotland, Aberdeen, Inventories of Records illustrating the History of the Burgh of (P. J. Anderson). 1890.

298. Glasgow. Hunterian Museum, Catalogue of Manuscripts in the (J. Young and P. H. Aitken). Glasgow, 1908 .

\section{IRELAND.}

299. Ireland. Lectures on the Manuscript Materials of Ancient Irish History (O'Curry). Dublin, 1861 .

\section{WALES.}

300. Wales. Catalogue of Manuscripts relating to Wales in the British Museum (E. Owen, Cymmrodorion Society, Record Series No. 4). 1900.

\section{France.}

301. Archives départementales communales et hospitalières. Catalogue des Manuscrits conservés dans les dépots des (U. Robert). Paris, 1886.

302. Catalogue Générale des Manuscrits des Bibliothèques publiques de départements. Paris, 1886 , etc.

303. Documents Manuscrits de l'Ancienne Littérature de la France conservés dans les Bibliothèques de la Grande Bretagne. (By P. Meyer, in Rapports à M. le Ministre de l'Instruction Publique; pt. 1. Paris, 1871 .

304. Delpit, J. Collection générale des documents français qui se trouvent en Angleterre. Paris, 1847.

305. Lechaude D'Anisy, A. L. Extraits des Chartes et autres Actes normands ou anglo-normands, qui se trouvent dans les Archives du Calvados. Caen, 1834-5.

See 2180 No. 138 . 
306. Omont, Henri. Catalogue Générale des Manuscrits des Bibliothèques Publiques de France. Paris, 1886 , etc.

307. PARIs, Bibliothèque Nationale, Inventaire générale et méthodique de la (L. V. Delisle). Paris, $1876-8$.

308. Raynaud, G. Catalogue des MSS. Anglais de la Bibliothèque Nationale. Paris, I 884 .

309. Riant, P. E. D. Inventaire critique des lettres historiques des Croisades. Paris, I880.

310. Robert, U. Inventaire des Cartulaires conservés dans les Bibliothèques de Paris et aux Archives Nationales. Paris, Epernay, I878.

311. - Inventaire Sommaire des Manuscrits des Bibliothèques de France dont les catalogues n'ont pas été imprimés. Paris, 1879-96.

312. - Etat des catalogues des manuscrits des Bibliothèques de France. Cabinet historique, I 877 , p. ror.

313. - de Belgique et de Hollande, Ibid., 1878 , p. 196 .

314. - de Danemark, de Norvège et de Suède, Ibid, I880, p. I Io.

315. - - Espagne et de Portugal, Ibid., I880, p. 294 .

316. Revue des Etudes Historiques. Paris, 1899 , etc. Under other titles since 1834 .

317. Revue des Bibliothèques. Paris, 1892.

3I8. Revue de Questions Historiques. Paris, 1866. etc.

\section{Belgium.}

319. Bibliothèque Royale de Belgique, Catalogue des Manuscrits de la (J. Van den Gheyn). Brussels, 1901, etc. 
320. Bruxelles. Commision royale d'histoire;

Bulletin. Brussels, 185 I, etc.

Containing Reports on foreign archives.

321. Wauters, A. Table Chronologique des Chartes et Diplômes Imprimés concernant l'histoire de la Belgique. Commission Royale d'histoire. Brussels, 1866-1904.

\section{Germany.}

322. Oesterly, H. Wegweiser durch die Litteratur der Urkundensammlungen. Berlin, I 885-6.

323. Streda, W. Ueber die Quellen der Handelsstatistik im Mittelalter. Berlin, 1902. Abbandlungen der königlichpreussischen Akademic der $W$ issenschaften.

\section{ITALY.}

324. Capasso, B. Le Fonti della Storia delle Provincie Napolitana del 568 al 1500.1902.

325. Instituto Storico Italiano. Fonti per la Storia d'Italia. Rome, 1887 , etc.

326. Mazzatinti, G. Gli Archivi della Storia d'Italia. Rocca Casciano, I897, etc.

327. - Inventari dei Manoscriti delle Biblioteche d'Italia. Forli, I 890-1906.

328. Ortino, G., and Fumagalli, G. Bibliotheca bibliographica Italica. Rome, I889, etc.

329. Archivio Storico Italiano. Florence, 1842 , etc. 330. Archivio Storico Lombardo. Milan, 1874, etc.

\section{SPain.}

331. BEER, R. Handschriftenschätze Spaniens $K$. Akad. der Wissenschaften. Sitzungsbericbte ... Phil. Hist. Klasse B. 124, etc. Vienna, I89I, etc. 
332. Befr, R. Mittelalterliche Bibliotheken Spaniens, etc. Allgemeine Zeitung. Tubingen, 1895 .

333. Carini, I. Gli Archivi e le Biblioteche di Spagna. Palermo, I 884-97.

\section{Division IV.-CATALOGUES OF MUSEUMS.}

It is now admitted that the sources of History include Monuments and other archaic objects as well as Documents, and for the study of the industrial arts the former class of evidence is of especial interest. Unfortunately, however, little use has hitherto been made of such sources by historical students, while the sources in question are generally deficient for the medieval period from the point of view of economic historical study. On the other hand, Catalogues of Museums are better arranged and more generally accessible in a printed form than is the case in respect of inventories of MSS., and it would seem to be very desirable that in future they should receive due recognition among the instruments of historical study. In addition to the several catalogues of the British Museum, the Victoria and Albert Museum, and other public institutions in London or provincial towns, there are valuable collections in the possession of a few local societies and individuals. Abroad, the Museum plays a more important part in the historical education of the nation, and such institutions as may be secn in Paris, Barcelona, Nuremburg, and Brussels (amongst others) are of great importance for mediæval economic study.

There is no collective catalogue of the catalogues of the Museums of Europe, but much information will be found in the Révue Internationale des Musées (1895I896), and reference may be made to individual catalogues, like those of the British Museum. Many civic museums contain MSS. and even archives. 
ENGLAND.

334. Colchester, Catalogue of the Antiquities in the Museum. Colchester, 1903, etc.

335. London, British Museum. Catalogue of English Coins, Anglo-Saxon Series (H. A. Grueber and C. F. Keary). 1893.

336. - Catalogue of Seals in the Department of Manuscripts (W. de G. Birch). 1887-1900.

337. — Guide to the Department of Coins and Medals. 1901 .

338. — A Guide to the Early Christian and Byzantine Antiquities. 1903.

339. — Guide to the Mediæval Room, etc. 1907.

340. - A Guide to the Antiquities of the Early Iron Age of Central and Western Europe (including the British Late Keltic period). 1905.

341. A Guide to the Antiquitics of the Bronze Age. I904.

342. - A Guide to the Antiquities of the Stone Age in the department of British and Mediæval Antiquities. 1902.

343. - Guildhall. Catalogue of the Collection of London Antiquities in the Guildhall Museum (C. Welch). 1903.

344. - Hertford House. Catalogue of European Armour and Arms in the Wallace Collection (G. F. Laking). 1910.

345. - Mint. Catalogue of Coins, Tokens, etc., in the Museum of the Royal (W. J. Hocking). 1906, etc.

346. Public Record Office. Catalogue of the Museum of the (Sir H. Maxwell Lyte). 1909.

347. - Victoria and Albert Museum. Ancient and Modern Furniture and Woodwork in the (J. H. Pollen). 1874. 
348. London, Victoria and Albert Museum. Textile Fabrics: Descriptive Catalogue of the Collection of Church Vestments, Dresses, Silk S.tuffs, Needlework and Tapestries forming that section of the Museum (D. Rock). I870.

349. -Tower. Guide (W. J. Loftie). 1908.

350. London and Middlesex Archeological Soc. Catalogue of Antiquities and Works of Art exhibited at Ironmongers' Hall, London, I861. (I 869).

351. Maidstone. Catalogue of the Kent Archæological Society's Collections at (G. Payne). Archaologia Cantiana, Vol. XIX., I 892).

352. Oxford, Ashmolean Museum. Catalogue. Oxford, 1836 .

353. Wiltshire. Catalogue of the Library of the Wiltshire Archæological and Natural History Society's Museum at Devizes (including the Devizes MSS.). Devizes, I 894 .

\section{SCOTLAND.}

354. Catalogue of the National Museum of Antiquities of (Society of Antiquaries of Scotland). Edinburgh, I 892 .

355. Catalogue of the Scottish Coins in the National Museum of Antiquities, Edinburgh. (Society of Antiquaries of Scotland). Edinburgh, Igor.

\section{IRELAND.}

356. Royal Irish Academy Collection: Guide to the Celtic Antiquities of the Christian period preserved in the National Museum (G. Coffey). Dublin, London, 1909. 


\section{MEDIEVAL ECONOMIC HISTORY}

France.

357. Album Archéologique des Musées de Province (Lasteyrie, R. de). Paris, I890, etc.

358. - Ministère de l'Instruction Publique Annuaire des Musées des Departements. Paris, 1900, etc.

For official publication of other Continental States, sec Minerva (No. 31). 


\section{Section II.-Auxiliary Studies.}

\section{HISTORICAL METHOD (including Historical Bibliography, Historical Criticism, and the Science of Archives).}

359. Acton, J. E. E. D. [Baron]. A Lecture on the Study of History. 1895 .

360. Bernheim, E. Lehrbuch der Historischen Methode und der Geschichtsphilosophie. Leipzig, I903.

36r. [CAmbridge] Essays on the Teaching of History (by F. W. Maitland, H. M. Gwatkin, etc., ed. W. A. J. Archbold). Cambridge, IgoI. 362. Cox, Rev. J. C. How to write the History of a Parish. 1909.

363. Droysen, J. G. Grundriss der Historik. Jena, I 858 [transl. Andrews, E. B. : Outline of the Principles of History. Boston, I893.

364. Foster, W. E. The point of view in History. Proceedings of the American Antiquarian Socicty, 1906, Vol. XVII., N.S., pt. 3, pp. $348 \mathrm{ff}$. Worcester, Mass., I906.

365. Freeman, E. A. The Methods of Historical Study. I 886.

366. Froude, J. A. Short Studies on Great Subjects. I 878. (I., I-38 ; II., 563-598.)

367. History and the Science of Archives. Athenaum, Jan. 7th, 1905, pp. 16-18.

368. Lamprecht, K. Moderne Geschichtswissenschaft. Freiburg im Breisgau, 1905, (transl. E. A. Andrews: What is History? New York, 1905.)

369. Langlois, Cir. V., and Ch. Seignobos. Introduction aux Etudes historiques. 3rd ed. Paris, 1905. Translated by G. G. Berry. Introduction to the study of history. 1898 . 
370. Meister, A. Grundriss der Geschichtswissenschaft zur Einführung in das Studium der deutschen Geschichte des Mittelalters und der Neuzeit. Leipzig, 1906-1908.

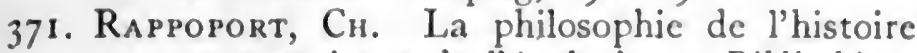
comme science de l'évolution. Bibliotheque d'études socialistes. Paris, n.d. [1903].

372. Schulz, M. Die Lehre von der historischen Methode bei den Geschichtschreibern des

Mittelalters. Berlin, Leipzig, 1909.

373. Seligman, E. R. A. The Economic Interpretation of History. New York, London, I902.

374. Smedt, P. C. DE. Principes de la Critique Historique. Liège, Paris, I 883 .

375. Stubis, W. Seventeen Lectures on the Study of Medixval and Modern History. 1900. (Lectures II-V.)

376. Villari, P. Is History a Science? (Studies Historical and Critical, translated by Linda Villari.) 1907.

\section{LINGUISTIC AND NOMENCLATURE.}

It has not been thought necessary to include references to works dealing with the grammar and structure of medireval languages. To the student who has a fair knowledge of classical Latin, mediæval texts in that language will present few difficulties (apart from those arising from the corruption or natural obscurity of the text) which cannot be solved by reference to Du Cange or some other glossary. For Old French the student may be referred to one of the numerous introductory works to that language; a convenient one in English is A Primer of Old French, by G. H. Clarke and C. J. Murray. For fuller information than will be found in an introductory work, reference may be made to the Grammaires bistoriques of A. Darmesteter (transl. G. A. Hartog) and K. Nyrop. There is no work, large or small, dealing 
adequately with Anglo-French considered apart from Old French ; but the former language does not present such marked differences as to render this of any particular inconvenience to the historical student, although a good glossary is much to be desired. For works dealing with Anglo-French, reference may be made to the excellent chapters treating of that language in Skeat's Principles of English Etymology, Second Series; to the unfinished work by L. E. Menger, The Anglo-Norman Dialect, and to Maitland's Introduction to Vol. I. of the Year Books of Edward II, which has been reprinted in the Cambridge History of English Literature, Vol. I., ch. xx. Many works of all sizes have been written on Old and Middle English: for the English student convenient introductions to Old English are the AngloSaxon Primer and Readers of Sweet, and, to Middle English Morris and Skeat's Specimens, or O. E. Emerson's Reader; as regards more advanced treatises it will be sufficient to refer to other works of Sweet and Skeat, and those of Morsbach and Sievers.

The number of glossaries of mediæval languages is constantly increasing with the number of newly edited texts. It is clearly impossible to attempt to give a list of them in the present work, but particular reference may be made to those appended to Skeat's edition of Piers Plowman and the works of Chaucer and G. C. Macaulay's edition of the works of Gower (Latin, French, and English).

\section{Dictionaries, Glossaries, and Word-Books.}

(i.) Latin.

377. Chevin, Abbé. Dictionnaire Latin-Français des Noms propres de Lieux. Bar-le-Duc, n.d. (I 897).

378. Du CAnge, C. DU Fresne. Glossarium mediæ et infimæ Latinitatis (L. Favre). Niort, I 883 - I 887 . 
379. Graesse, J. G. T. Orbis Latinus, oder Verzeichniss der wichtigsten lateinischen Orts-und Ländernamen. Berlin, Igog.

380. Martin, C. T. The Record Interpreter, p. 177 et seq. 1910.

381. Maynew, A. L. Promptorium Parvulorum. E.E.T.S. 1908. App. C.: Glossary of the Medixval Latinity of the Promptorium.

382. Pipe Roll Society. Introduction to the Study of the Pipe Rolls (including table of abbreviations and glossary). 1884. Pipe R. Soc., Vol. III.

383. Schmidt, C. Petit supplément au dictionnaire de Du Cange. Strasburg, 1906.

384. Spelman, H. Glossarium Archaiologicum. 1687.

(ii.) French.

385. Cledat, L. Petit glossaire du vieux français precédé d'une introduction grammaticale. Paris, 1887.

386. Cotgrave, R. French-English Dictionary. 1650. Ist ed. 16i I.

387. Godefroy, F. Dictionnaire de l'ancienne langue française et de tous ses dialectes du IXc au XVe siecle. Paris, 1880-1902.

388. - Lexique de l'ancien Français. Paris, I901. Librairie universitaire française et étrangère. 389. Kelham, R. A Dictionary of the Norman or Old French Language. 1779.

390. LABORDE, L. DE. Glossaire français du moyen âge à l'usage de l'archéologue et de l'amateur des arts. Paris, 1872.

391. Lamond, E. (cd.). Walter of Henley's Husbandry. 1890 . R. Hist. Soc. (Glossarial index.) 392. LaRchey, L. Dictionnaire des noms contenant la recherche étymologique des formes anciennes de 20,200 noms relevés sur les annuaires de Paris. Paris, 1880. 
393. Métivier, G. Dictionnaire Franco-Normand. 1870 .

394. Morsy, H. Glossaire comparatif Anglo-Normand. Caen, I 889-95.

395. Nichols, F. M. (ed.). Britton. I 865. (Glossary of obsolete French words, vol. II, p. 363.)

396. Ste. Palaye, La Curne de. Dictionnaire historique de l'ancien langage françois. Paris, Niort, I 875-1882.

397. Studer, P. The Oak Book of Southampton. Supplement. (Notes on the Anglo-French dialect and glossary.) Soutbampton Record Soc. $X$., I9I I.

398. Toynbee, P. Specimens of Old French (IX.$\mathrm{XV}$. Centuries) with introduction, notes, and glossary. I 892.

(iii) English.

399. Bardsley, C. W. English surnames: their sources and significations. I897.

400. Bosworth, J. An Anglo-Saxon dictionary (ed. T. N. Toller). I 898. Supplement, pt. I, I908. 40I. Hall, J. R. C. A concise Anglo-Saxon Dictionary. I 894 .

402. Halliwell, J. O. A dictionary of archaic and provincial words, obsolete phrases, proverbs, and ancient customs from the 14 th century. I904.

403. Herrtage, S. J. H. Catholicon Anglicum: An English-Latin word-book, dated 1483. I881 (E.E.T.S. 75). (Also Camden Soc. N.S. 30, I882.)

404. Mätzner, E. Altenglische Sprachproben nebst einem Wörterbuche [A-M only]. Berlin, I 867-I 900 .

404a. Mayhew, A. L. and W. W. Skeat. A concise Dictionary of Middle English. Oxford, 1888. 
405. Maynew, A. L. The Promptorium Parvulorum.

The first English-Latin Dictionary. 1908. (E.E.T.S.) Also ed. A. Way, Camden Soc., I 862-65.)

406. Murray, J. A. H. A new English dictionary on historical principles. 1884. (In progress). 407. Payne, W., and Herrtage, S. J., Tusser's Five Hundred Pointes of Good Husbandrie, p. 235 notes and illustrations, p. 319 glossary. English Dialect Socicty. 1878.

408. Rastell, W. Les termes de la Ley. 172 I. 409. Stratmann, F. H. A Middle English Dictionary. I $89 \mathrm{I}$.

410. Sweet, H. Student's Dictionary of AngloSaxon. 1897.

411. Wright, T. Anglo-Saxon and Old English Vocabularies (R. P. Wülcker). I 884.

412. Wright, J. The English Dialect Dictionary. 1898-1905.

(iv) Welsh.

413. Evans, D. Silvan. Dictionary of the Welsh language. 1887 , etc.

(v) Miscellaneous.

414. Beck, S. W. The Draper's Dictionary. [1886.] 415. Blount, T. Tenures of land and customs of Manors. New ed. by W. C. Hazlitt. p. 4I, glossary. 1874. (Supplement, 1909.)

416. Cowell, J. A Law Dictionary. 1727.

417. Gross, C. The gild merchant. 1890. (Glossary of English, French, and Latin words, Vol. II, p. 293.)

4I8. Jасов, G. The Law-dictionary (T. E. Tomlins). 1835.

419. Kennetr, W. A glossary of words and phrases. Parochial Antiquities, new ed., i 818, Vol. II. 


\section{A SELECT BIBLIOGRAPHY OF}

420. Klump, W. Die altenglischen Handwerkernamen. (Angl. Forsch. Heft 24.) Heidelberg, 1908. 421. Mowat, J. L. G. Alphita: A medico-botanical glossary [15th c.]. I887. Anecdota Oxoniensia, Med. and Mod. series, Vol. I., pt. 2.

422. Palgrave, R. H. I. Dictionary of Political Economy. I894-1908.

423. Parker, J. H. Glossary of terms used in Architecture. I850.

424. Rushen, P.C. TheGenealogist'sLegal Dictionary. Genealogist's Pocket Library, VI. 1909.

425. Sмчтн, W. H. The sailor's word-book. I 867.

\section{PAL EOGRAPHY AND DIPLOMATIC.}

\section{A.-PaLmography.}

(a) Treatises and Articles. (General.)

426. Deliste, L. Mémoire sur l'école calligraphique de Tours au IXe siècle (reprinted from Mémoires de l'Académie des Inscriptions et Belles-Lettres XXXII.). Paris, I885.

427. Hall, H. Studies in English Official Historical Documents. Pt. 3. 1908.

428. HARDY, W. J. Handwriting of the Kings and Queens of England. I 893 .

429. Keller, W. Angelsächsische Palæographie (Palaestra XLIII. Ed. by A. Brandl, G. Röthe and E. Schmidt). Berlin, Igo6.

430. Lindsay, W. M. Early Irish minuscule script. (St. Andrew's University Publications, VI.) I9IO.

431. MADAN, F. Books in Manuscript. 1893.

432. Meister, A. Grundriss der Geschichtswissenschaft. Band I, pp. 21-I30. Lateinische Paläographie by B. Bretholz. Leipzig, 1906. 433. Mrgne, J. P. (ed). Nouvelle encyclopédie théologique XLVII. (Dictionnaire de paléographie). Paris, 1854 . 
434. Prov, M. Manuel de paléographic latine et française. Paris, 19 ro.

435. Reusens, E. H. J. Eléments de paléographie. Louvain, I 899 .

436. Robert, U. Note sur l'origine de l'E cédillé dans les manuscrits. Mélanges fulien Havet, pp. 633-7. Paris, 1895 .

437. Tномpson, E. M. Handbook of Greek and Latin Palzography. 1906.

438. Тночтs, Е. Е. (Mrs. Cope). How to decypher and study old documents. 1909.

439. Traube, L. Zur Paläographie und Handschriftenkunde. In Vorlesungen und Abhandlungen B. I. (P. Lehmann). Munich, 1909. 440. Wattenbach, W. Anleitung zur lateinische Paläographie. Leipzig, 1886.

44I. Wright, A. Courthand Restored. (C. T. Martin.) 1879 .

(b) Treatises and Articles on Special Subjects.

(i) Paper-making.

442. Cross, C. F., and Bevan, E. J. A text-book of paper-making. 1907.

443. Jenkins, R. Early attempts at paper-making in England. Library Association Record, ii. 479-88, 577-88, iii. 239-51, iv. 128-39. I900-2.

(ii) Water-marks.

444. Briquet, C. M. Les filigranes. Paris, 1907. 445. Sotнeвy, S. and S. L. A collection of specimens of water-marks on paper (British Museum).

(iii) Scriptorium.

446. Caneparius, P. M. De atramentis. I660. 447. Clark, J. W. The Care of Books. 1902 ; reissue, 1910.

448. Gasquet, F. A. The Old English Bible (Pp. 35-53, The Monastic Scriptorium). 1908. 
449. Hardy, T. D. Descriptive Catalogue of Manuscripts. (III., pp. xxxii. et seq. The St. Albans School of Writers.) Rolls Series. I 862-7I.

450. Merryweather, F. S. Bibliomania in the Middle Ages (ed. C. Orr, 1900). I 849.

45 I. Putnam, G. H. Books and their Makers during the Middle Ages. New York, 1896.

452. Savage, E. A. Old English Libraries. The Antiquary's Books. I9II.

453. Wattenbach, W. Das Schriftwesen im Mittelalter. Leipzig, I896.

(iv) Extensions.

454. Burton, J. H. The Register of the Privy Council of Scotland. Vol. I. Preface, pp. xliv.-liv. 1877 .

455. England. The Fortieth Annual Report of the Deputy-Keeper of the Public Records. App. No. 14 (Regulations to be observed in making Office Copies). I 879 .

456. Pipe Roll Society. Publications, XXIX. Preface. 1908.

(v) Illuminations.

457. Birch, W. de G., and Jenner, H. Early drawings and illuminations. 1879 .

458. Herbert, J. A. Illuminated Manuscripts. (The Connoisseur's Library.) 191 I.

459. Middleton, J. H. Illuminated Manuscripts in Classical and Mediæval Times. 1892.

460. Shaw, H. The Art of Illumination as practised during the Middle Ages. 1870.

46r. Thompson, E. M. English Illuminated MSS. A.D. 700 to the $15^{\text {th }}$ century. (Bibliographica I., I29-55 and 385-403; II., I-20.) 1895-6. 


\section{(c) Abbreviations.}

462. Cappelli, A. Dizionario dei Abbreviature Latine ed Italiane. Milan, I899.

463. Lindsay, W. M. Contractions in early Latin Minuscule MSS. 1908.

464. Martin, C. T. The Record Interpreter. 1910. 465. Pipe Roll Society. Publications, III., pp. I-34. 1884 .

(d) Collections of Facsimiles.

(i) England.

466. Bond, E. A. Facsimiles of Ancient Charters in the British Museum. I873-8.

467. Delisle, L. Recueil des Actes de Henri II. (Atlas.) Paris, 1909.

468. Palæographical Society. Publications. 1873-94. 469. -New, Publications. I903, etc.

470. Warner, G. F., and Ellis, H. J. Facsimiles of Royal and other Charters in the British Museum. (Vol. I., William I.-Richard I.) 1903.

(ii) France.

47I. Delisle, L. Album paléographique de l'école des Chartes. Paris, 1887.

472. - Le cabinet des manuscrits de la Bibliothèque Nationale. Paris, I868-8I.

473. L'Ecole des Chartes, Recueil de Facsimiles à l'usage de. Paris, 1880 , etc., in progress.

474. Prou, M. Recueil de Facsimiles du XIIe au XVIIe siècle. Paris, I 892 .

475. - Nouveau Recueil de Facsimiles du XIIe au XVIIe siècle. Paris, I 896.

476. - Recueil de Facsimiles du Ve au XVIIe siècle. Paris, 1904.

477. - Manuel de paléographie. Atlas. Paris, 1910. 
(iii) Germany.

478. Chroust, A. Monumenta Palæographica. Munich, I899, etc.

479. Steffens, F. Lateinische Paläographie. Freiburg, 1903, etc.

(iv) Holland.

480. Brugmans, H., and Oppermann, O. Atlas der Nederlandische Palæographie (I rooI700). The Hague, I9ro.

(v) Italy.

48r. Monaci, E., and Paoli, C. Archivio Paleografico Italiano. Rome, 1882-I890.

(vi) Spain.

482. Ewald, P., and Loewe, G. Exempla Scripturæ Visigothicæ. Heidelberg, 1883 .

\section{B.-Diplomatic.}

(a) Treatises and Articles on Diplomatic. 483. Anderson, J., and Ruddiman, T. Selectus diplomatum et numismatum Scotiae thesaurus. I739.

484. Aronius, J. Diplomatische Studien uber die älteren angelsächsischen Urkunden. Königsberg in $\operatorname{Pr}$. [1884].

485. Ayliffe, J. Parergon Juris Canonici Anglicani. I734.

486. Bemont, C. Rôles Gascons. T. i. Supplement, pp. xii.-xxvi. Paris, r8g6.

487. Birch, W. DE Gray. Index of the styles and titles of the Sovereigns of England. Index Society. 1879.

488. Bresslau, H. Handbuch der Urkundenlehre. Leipzig, I889, etc. 
489. Delisle, L. Memoire sur la chronologie des Chartes de Henri II. Reprinted from Bibliotheque de l'École des Chartes, LXVII., 36r-401. Paris, 1906.

490. - Notes sur les chartes originales de Henri II. Reprinted from Bibliotheque de l'Ecole des Chartes, LXVIII., 272-314. Paris, 1907.

491. - Les formules Rex Anglorum et Dei Gratia Rex Anglorum. Reprinted from Bibl. de l'Ec. des Ch., LXVIII., pp. 525-36. 1907. cf. J. H. Round in Archaological Journal, LXIV., 63-79, 1907, and R. L. Poole in Engl. Hist. Riv., XXIII., 79, 1906.

492. - Recueil de 109 chartes originales de Henri II. Bibliothéque de l'École des Chartes, LXIX., 54I-80, 738-40. Paris, 1908.

493. Recueil des Actes de Henri II. Paris, 1909. 494. Déprez, E. Études de Diplomatique Anglaise (1272-1485). Paris, I908.

495. Earle, J. A Handbook to the Land Charters.

pp. xv.-xliii. 1888 .

496. Fitzherbert, A. The new Natura Brevium.

1755 .

497. GıRY, A. Manuel de diplomatique. Paris, 1894. 498. Hall, H. Studies in English Official Historical Documents. Pt. 2. I 908 .

499. - A Formula Book of English Official Historical Documents. Pts. I and 2. I 908-9.

500. Hardy, T. D. Prefaces to Rot. Lit. Claus. (1833), Rot. Lit. Pat. (1835), Rot. Chart. (1837), Rot. de Liberate, etc. (1844). Record Commission.

501. Hickes, G. Thesaurus (Dissertatio epistolaris). $1703-5$.

502. Hrabar, V. E. De Legatis et Legationibus Tractatus Varii. Dorpat, 1905.

503. Kemble, J. M. Codex Diplomaticus. Vol. I., Intro., pp. ix.-cxii. I839-48. 
504. Madox, T. Formulare Anglicanum. i.-xxxiv. 1702.

505. Meister, A. Grundriss der Geschichtswissenschaft. Band I., pp. 131-266. (Diplomatik by R. Thommen, L. Schmitz-Kallenberg, and H. Steinacker.) Leipzig, 1906.

506. Poole, R. L. The teaching of Palæography and Diplomatic. Essays on the Teaching of History, ed. W. A. J. Archbold, pp. II-30. 1901.

507. Round, J. H. Ancient charters royal and private prior to A.D. I200. Pipe Roll Society, X. I 888 .

508. Stevenson, W. H. The Old English charters of St. Denis. Engl. Hist. Rev., VI., 736-42. I 891 .

509. - -An old English charter of William the Conqueror in favour of St. Martin's Le Grand, London, A.D. $1068 . \quad$ Eng. Hist. Rev., XI., 731. 1896.

510. - and Round, J. H. An old English charter of William the Conqueror, 1068. Engl. Hist. Rev., XII., 105. 1897.

511. - An inedited charter of Henry I. Eng. Hist. Rev., XXI., 505. 1906.

512. Tassin and Toustain. Nouveau traité de diplomatique. Paris, 1750-65.

513. Zeumer, K. Monumenta Germaniæ Historica Leg. Sectio V. (Formulæ Merovingici et Karolini Aevi.) Hanover, 1882-6.

(b) Chronology.

514. Anscombe, A. The Anglo-Saxon computation of historic time in the ninth century. (British Numismatic Fournal, Ist series, IV., 241310 ; V., 381-407. 1907-9.)

515. BoND, J. J. Handy book of rules and tables for verifying dates with the Christian era. 1889 . 
516. Cappelli, A. Cronologia. Milan, 1906.

517. Dunbar, A. H. Scottish Kings. 1906.

518. Hampson, R. T. Medii Aevi Kalendarium. I841. 519. Mas Latrie, L. De. Trésor de Chronologie. Paris, 1889.

520. Meister, A. Grundriss der Geschichtswissenschaft. Band I. Abt. I. pp. 267-319. (Chronologie by H. Grotefend.) Leipzig, 1906.

521. Selby, W. D. The Jubilee date-book. The regnal years of the kings and queens of England. 1887.

(c) Sigillography.

522. BIRCH, W. DE G. Seals. (Connoisseur's Library.) 1907.

523. - On the Three Great Scals of King Edward the Confessor. (Reprinted from Trans. Royal Soc. of Lit., and series, X., pp. I 36-48.) 1874 .

524. - On the Great Seals of William the Conqueror. (Reprinted from Trans. Royal Soc. of Lit., 2nd series, X., pp. 149-79, 180-84.) 1874 .

525. - On the Great Seals of William II. (Reprinted from the Fourn. of the Arch. Assoc., XVIII., pp. I 29-4I.) I 872.

526. - On the Great Seals of King Henry I. (Reprinted from the Fourn. of the Arch. Assoc., XXIX.s pp. 233-62.) 1873.

527. - On the Great Seals of King Stephen. (Reprinted from Trans. Royal Soc. of Lit., 2nd series, XI., pp. 1-29.) 1874.

528. - On the Great Seals of Henry II. (Reprinted from Trans. Royal Soc. of Lit., 2nd series, XI., pp. 301-37.) 1876.

529. Broom, J. H. English Seals. The Antiquary's Books. 1906. 
530. Demay, G. Inventaire des sceaux de la Normandie. Paris, $\mathrm{r} 88 \mathrm{I}$.

531. Ellis, T. E. (Lord Howard de Walden). Some feudal Lords and their Seals, MCCCI. De $W$ alden Library. I904.

532. Hope, W. H. St. John. Seals of the Colleges and of the University of Cambridge. Proceedings of the Soc. of Antiquaries, and series, X., Pp. 225-52. 1883-5.

533. - Seals of English Bishops, ibid., and series, XI., pp. 271-306. I885-7.

534. - Seals of the Bishops of Bath and Wells. Somersetsbire Arch. and Nat. Hist. Soc. Proceedings, XXIV., pp. 29-39. 1889.

535. - A Third Great Seal of King Stephen. Proceedings of Soc. of Antiquaries, 2nd series, XIX., pp. 60-5. I90I-3.

536. Laing, H. Descriptive catalogue of Impressions from Ancient Scottish Seals. I850-66.

537. Lecoy de la Marche. Les sceaux. Paris, I889. 538. Pedrick, G. Monastic Seals of the I 3 th century. 1902.

539. - Borough Seals of the Gothic period. I904. 540. Wron, A. B., and A. The Great Seals of England. 1887 .

\section{COINS, WEIGHTS AND MEASURES.}

541. Blanchet, J. A. Nouveau Manuel de Numismatique du Moyen Age et Moderne. Paris, I890.

542. Burns, E. The Coinage of Scotland. Edinburgh. 1887 .

543. Donisthorpe, W. System of Measures. I 895.

544. Dublin Science and Art Museum, Catalogue of Irish Coins, 1895.

545. Engel, A., and Serrure, R. Traité de Numismatique du Moyen Age. Paris, I891-1905.

546. Evans, J. The Coins of the Ancient Britons, with supplement. $\mathbf{1} 890$. 
547. Grueber, H. A. Handbook of the Coins of Great Britain and Ireland in the British Museum. 1899.

548. Guilhiermoz, P. Note sur les poids du moyenâge. Paris, 1906, etc. Bibliotheque de l'É cole des Chartes, tom. 67.

549. Hawkins, E., and Kenyon, R. Ll. The Silver Coins of England. 1887.

550. Kenyon, R. LL. The Gold Coins of England. 1884 .

551. Lindsay, J. A view of the Coinage of Ireland. Cork, 1839.

552. Luschin von Ebengreuth, A. Allgemeine Münzkunde und Geldgeschichte des Mittelalters und der Neueren Zeit. Munich-Berlin. 1904.

553. Report of the Commission on the Royal Mint. Parliamentary Papers, I849, Vol. XXVIII. 1849. Mint.

Statement (A) (pp. $5-66$ ) relates to the establishment of the

554. Richardson, A. B. Catalogue of the Scottish Coins in the National Museum of Antiquities, Edinburgh, I901.

555. Ruding, R. Annals of the Coinage of Great

Britain and its Dependencies. I840.

556. Shaw, W. A. The History of Currency, 12521894. 1896.

557. Watson, C. M. British Weights and Measures. 1910.

\section{ARCHÆOLOGY.}

(For periodical publications see Appendices.)

(a) Antiquities.

558. CAMDEN, W. Remains concerning Britain.

Library of O'd Authors, 1856.

559. Dawkins, W. Boyd. Early Man. I880. 
560. Evans, Sir J. The ancient Bronze Implements, Weapons, and Ornaments, of Great Britain. I 881 .

56r. Godwin, H. English Archæologists' Handbook. 1867.

562. Grose, F. The Antiquities of England and Wales. 1783 .

563. Haverfield, F. J. The Romanization of Roman Britain. British Academy Proceedings, II. 1906.

564. Holmes, T. R. E. Rice. Ancient Britain. 1907. 565. Horsley, J. Britannia Romana. 1732.

566. KeARY, C. F. Dawn of History. 1888. 567. Leland, John. De Rebus Britannicis Collectanea (T. Hearne). I774.

568. - The Itinerary of 1535-1543 (L. ToulminSmith). I9I0.

569. Luввоск, J. (Lord Avebury). Prehistoric Times. 1900.

570. Munro, R. Prehistoric Scotland. 1899.

571. Murray, D. Archæological Survey of the United Kingdom. 1896.

572. Sharpe, M. Some antiquities of Middlesex in British, Roman, and Saxon times. 1905.

573. WARD, J. The Roman Era in Britain. Antiquary's Books. I9II.

574. Windee, B. C. A. Life in Early Britain. 1897. 575. Wright, T. Archæological Album. 1845.

(b) Architecture.

(i) Treatises, General.

576. Barnard, F. P. Companion to English History (5th-16th cent.). 1902.

577. Brown, G. B. The care of Ancient Monuments. 1905.

578. England. Royal Commission on Historical Monuments. Publications. 1910, etc. 
579. Fergusson, J. History of Architecture in all countries (R. P. Spiers). 1893, etc.

580. Morris, W. Architecture and History. 1900. 58r. Porter, A. K. Medieval Architecture. I 909. 582. Perry, J. T. Chronology of Medixval and Renaissance Architecture. 1893 .

583. Perry, J. T. The influence of the Hanseatic League on the Architecture of Northern Europe. Fournal of the Royal Society of British Architccts, I 893-94. 3rd ser., Vol. I.

(ii) Treatises, Special: Gothic.

584. Bond, F. Gothic Architecture in England (IIthI6th cent.). 1905.

585. BrAsh, R. R. Ecclesiastical Architecture of Ireland to the I2th century. 1875 .

586. Clay, R. M. The Medireval Hospitals of England. Antiquary's Books. 1909.

587. Gasquet, F. A. The Greater Abbeys of England. 1908.

588. Lethaby, W. R. Westminster Abbey and the King's Craftsmen. 1906.

589. Parker, J. H. Introduction to the study of Gothic Architecture. I 88I.

590. Pratt, H. M. The Cathedral Churches of England. Igro.

59r. MacGrbbon, D., and Ross, T. Ecclesiastical Architecture of Scotland. Edinburgh, 1896-7. 592. Prior, E. S. History of Gothic Art in England. 1900.

593. Stokes, M. McN. Early Christian Architecture in Ireland. 1878.

(iii) Treatises, Special: Domestic.

594. Addy, S. Evolution of the English House. 1908.

595. Ditchfield, P. H. The Manor Houses of England. 1910. 
596. Files, G. T. The Anglo-Saxon House. Leipzig, 1903.

597. Gотсн, J. A. The growth of the English House from I I 100-I 800. I 1909.

598. Macgibbon, D., and Ross, T. The castellated and domestic Architecture of Scotland. I 887 -I 892 .

599. Parker, J. H. Domestic Architecture of the Middle Ages, from Edward I. to Henry VIII. I 853-59.

600. Turner, T. H. Some account of Domestic Architecture in England from the Conquest to the end of the 13 th century. 1877 .

(iv) Treatises, Special: Military.

601. Allcroft, A. H. Earthworks of England. 1908. 602. Armitage, E. S. Early Norman Castles of the British Isles. I9II.

603. Clark, G. T. Mediæval Military Architecture in England. I 884.

604. Historical Association. The development of the Castle in England and Wales. (Leaflet 22.) 1910.

605. MacGibbon, D., and Ross, T. Op. cit.

(v) Dictionaries.

606. Architecture, Dictionary of. (Arcbitectural Publication Society.) r 849-1892.

607. Atrinson, T. D. Glossary of terms. igro. 608. Parker, J.H. Glossary of terms used in Grecian, Roman, Italian, and Gothic Architecture. I 896.

609. Sturgis, R. A Dictionary of Architecture and Building. r $90 \mathrm{r}$.

610. Viollet-Le-Duc, E. E. Dictionnaire raisonnée de l'architecture française. XI. au XVI. siècle. Paris, I 858-68. 


\section{(c) Arts and Crafts. \\ (i) General Authorities.}

6ri. Allen, J. R. Celtic Art in Pagan and Christian times. Antiquary's Books. 1904.

612. Brown, G. Baldwin. Arts in Early England. 1903 , etc.

613. Arts and Crafts of our Teutonic forefathers. 1910.

6r4. Glazier, R. Manual of Historic Ornament. 1906.

615. Lacroix, Paul. The Arts in the Middle Ages and the Renaissance (W. Armstrong). 1886. 616. Lethaby, W. R. Medixval Art (312-1350). 1904.

617. Roger-Mrles, L. Comment discerner les styles du VIII.-XIX. siècles. 1896-8.

\section{(ii) Armour.}

618. Arrows and arrowmakers. Washington, 1891. 6rg. Ashdown, C. H. British and Foreign Arms and Armour. 1909.

620. Ffoulkes, C. Armour and Weapons. I9ro.

621. Gardner, J. S. Armour in England (to the 17 th century). $\quad 1897$.

622. Longman, C. J., and Walrond, Col. H. Archery. (Badminton Library.) 1894.

623. Payne-Gallwey, Sir R. W. The Crossbow, Mediæval and Modern. 1907.

(iii) Costume.

624. Ashoown, Mrs. C. H. British Costume during XIX. centuries. (Civil and ecclesiastical.) 1910.

625. Calthrop, D. C. English Costume. 1906. 626. CLinch, G. English Costume from prehistoric times to the end of the 18 th century. (Antiquary's Books.) 1909. 
627. Demay, G. Le costume au moyen-age d'après les sceaux. Paris, I880.

628. Druitr, H. Costume on Brasses. I 906.

629. Fairholt, F. W. Costume in England. (History and Glossary.) I885.

630. Hill, G. History of English Dress. 1893.

631. Lavisse, E., et Parmentier, A. Album historique, I 898-1907. (4th-rgth cent.)

632. Planche, J. R. History of British Costume. 1907.

633. Strutt, J. Dress and habits of the People of England. I842.

(iv) Furniture.

634. Cox, J. C., and Harvey, A. English Church Furniture. Antiquary's Books. 1907.

635. Havard, H. Dictionnaire de l'ameublement et de la décoration, etc. I 887-90.

636. Litchfield, F. Illustrated History of Furniture. 1907.

637. MacQuoid, P. History of English Furniture. Age of Oak. r904.

638. Pollen, J. H. Ancient and modern Furniture and Woodwork (ed. T. A. Lehfeldt). I908, etc.

(v) Sculpture.

639. Prior, E. S. Mediæval Figure Sculpture in England. Arcbitectural Review, XII.-XVII.) I $902-05$.

(vi) Brasswork.

640. Boutell, C. Monumental brasses and slabs. 1847.

641. Perry, J. T. Dinanderie: A history and description of Mediæval Art work in copper, brass, and bronze. I9ro. 
(vii) Glass.

642. Winston, C. Ancient glass paintings in England. 1867 .

(viii) Painting.

643. KeYser, C. E. A list of buildings in Great Britain and Ireland having mural and other painted Decorations, etc. 1883.

644. Merrifield, M. P. Original treatises on the Art of Painting, 12 th-I 8 th century. 1849.

For Illumination see Nos. $457-46$ r.

(ix) Plate and Pottery.

645. Сhurch, A. H. English Earthenware. South Kensington Museum Hand Books. 1904.

646. CRIPPS, W. J. Old English plate: makers and marks. 1906.

(x) Tapestry.

647. Fowke, F. R. History of the Bayeux Tapestry. 1898.

648. Müntz, E. La Tappisserie. Trsl. (L. G. Davis) 1885.

649. Thомson, W. G. A history of Tapestry. 1906.

VI. BIOGRAPHY (including Genealogy and Heraldry).

(a) Guides, Treatises, and Articles.

650. Boutell, C. English Heraldry (A. C. Fox Davies). 1908.

651. Burke, J. The Royal Families of England, Scotland, and Wales, with their descendants. I $848-5 \mathrm{I}$.

652. Campbell, J. Lives of the Chief Justices of England. 1874 .

653. - Lives of the Lord Chancellors of England. I $845-69$.

654. Cokayne, G. E. Complete Peerage. i 887-1898.

New edition by Hon. Vicary Gibbs in course of publication. 
655. Collectanea Topographica and Genealogica (ed. Nichols, J. G.) 1836.

Vol. III., Banners, Standards, and Badges (Temp. Henry VIII.), pP. 49-76.

656. Doren, J. The Book of the Princes of Wales. I 860 .

657. Dugdale, Sir W. The Baronage of England. $1675-7$.

658. Fairbairn, J. Book of Crests of the families of Great Britain and Ireland. 1905.

659. Foss, E. The Judges of England. I 848-64. Abridged under the title Biograpbia Furidica. I 870.

660. Foster, J. The Peerage, Baronetage, and Knightage of the British Empire. I879-83. 661. Gams, P. B. Series episcoporum. Ratisbon. I873-86.

662. Green, M. A. E. Lives of the Princesses of England. I $849-55$.

663. HAYDN, J. The Book of Dignities. I894.

664. Le Neve, P. Fasti ecclesiæ Anglicanæ. 1854. 665. Marshall, G. W. The Genealogist's Guide. 1879.

666. Nicolas, N. H. Notitia Historica. 1824.

667. Phillimore, W. P. W. How to write the history of a family. 1896.

668. - Pedigree Work: A handbook for the Genealogist. 1900.

669. Pughe, W. O. Cambrian Biography. 1803.

670. Round, J. H. Studies in Peerage and Family history. I90I.

671. - Peerage and Pedigree. I9ro.

672. - Introduction of Armoria Bearings into England. Arch. Journ. LI, 44.

673. SHAw, W. A. The Knights of England. 1906.

674. Sheriffs, List of, for England and Wales, from the earliest times to A.D. I831. Public Record Office Lists and Indexes, No.IX. 1898. 
675. Sims, R. Manual for the Genealogist, Topographer, Antiquary, and Legal Professor. 1861.

676. Stokvis, A. M. H. J. Manuel d'histoire, de généalogie et de chronologic. Leyden, 1888-93. (Vols. II. and III.)

677. Strickland, A. Lives of the Queens of England. 1864-5. Bobn's Historical Library.

678. StubBs, W. Registrum sacrum Anglicanum. 1897.

679. Walden, Lord Howard de. Banners, Standards, and Badges. 1904.

680. Williams, R. F. Lives of the English Cardinals. I 868.

681. Woodward, J. A treatise on Ecclesiastical Heraldry. I 894 .

682. Woodward, J., and Burnett, G. A treatise on Heraldry, British and foreign. 1892.

\section{(b) Dictionaries.}

683. Burke, J., and Burke, J. B. General Armory of England, Scotland, Ireland, and Wales. I 884 .

684. Dictionary of Christian Biography .. [ [to about A.D. 800] (W. Smith and H. Wace). $1877-87$.

685. Dezobry, L. C., and Badrelet, J. L. T. Dictionnaire de biographie et d'histoire. I903.

686. Elvin, C. N. Dictionary of Heraldry. I 889. 687. GatField, G. Guide to printed books and manuscripts relating to English and foreign heraldry and genealogy. 1892 .

688. Gougr, H. Glossary of terms used in Heraldry. I 894 .

689. Hoefre, J. C. F. Nouvelle biographie générale. $1855-66$.

690. National Biography, Dictionary of (Sidney Lee and Leslie Stephen). 1908-9. 
691. Papworth, J. W. Alphabetical dictionary of Coats of Arms belonging to families in Great Britain and Ireland. I858-74.

692. Wright T. Biographia Britannica literaria. I $842-6$.

\section{GEOGRAPHY AND TOPOGRAPHY.}

(a) Treatises and Essays.

693. BeAzley, C. R. The dawn of modern geography. I 897-1906.

694. Chalmers, G. Caledonia; or, an account, historical and topographic, of North Britain. Paisley, I887-1902.

695. Chisholm, G. G. On the distribution of towns and villages in England. (Geog. Fourn. IX. 76 and X. 5 I I.) 1897.

696. FreEMAN, E. A. Historical Geography of Europe (ed. J. B. Bury). 1903.

697. Jusserand, J. A. A. J. English Wayfaring Life in the Middle Ages (transl. by L. T. Smith.) I 892 [I89I].

698. Kretschmer, K. Historische Geographie von Mitteleuropa (A. Meister). Grundriss, etc. Munich, 1904.

699. Leland, J., The Itinerary of (ed. L. T. Smith). I906-IO.

700. Lelewel, J. Géographie du Moyen Age. Brussels, $1852-57$.

70I. Mackinder, H. J. Britain and the British Seas. 1907. [B.]

702. Nichols, J. Bibliotheca Topographica Britannica $1780-1790$.

703. - Miscellaneous Antiquities (in continuation of Bibl. Top. Brit.). I79I-I800.

704. Rudler, F. W., and Chisholm, G. G. Europe. 1902. (Stanford's compendium of Geography and Travel.) 
705. Scotland, New statistical account of. 1845.

706. Stukfley, William. Itinerarium Curiosum.

1776.

See also No. 101.

\section{(b) County Histories.}

Historics of the individual counties of England are numerous, but vary greatly in economic interest.

The Victoria County History series is intended to be a complete survey of all the counties, but is not yet completed Other histories, with valuable material for economic purposes, are given below.

707. Clutterbuck, R. The history and antiquities of the county of Hertford. I 81 5-27.

708. Eyton, R. W. The Antiquities of Shropshire. $1853-60$.

709. Hasted, E. The history and topographical survey of Kent. Canterbury, I778-99, 1797-1801. (H. H. Drake, pt. I, I 886.)

710. Hodgson, J. A History of Northumberland. Newcastle upon Tyne, 1827-20-40.

A new edition in progress (No. 717 ).

7II. Hutchins, J. The history and antiquities of the county of Dorset. 186I-73.

712. Innes, C. Origines Parochiales Scotix. Bannatyne Club. Edinburgh, I 850-55.

713. Lipscomb, G. The history and antiquities of the county of Buckingham. I 847-31.

714. Manning, O. The history and antiquities of the county of Surrey (cont. by W. Bray). 1804-14. 715. NASH, T. R. Collections for the history and antiquities of Worcestershire. (Appendix, supplement.) I781-99.

716. Nichols, J. The history and antiquities of the county of Leicester. I795-1815.

717. Northumberland, A history of. (Northumb. Co. Hist. Committec.) Newcastle-upon-Tyne, 1893, etc. 
718. Ormerod, G. The history of the County Palatine and City of Chester. I882. [1875-82.]

719. Shaw, L. The history of the province of Moray. Glasgow, 1882.

720. Surtees, R. The history and antiquities of the County Palatine of Durham. I816-40.

721. Yeatman, J.P. The feudal history of the county of Derby. 1886, etc.

\section{(c) Gazetteers.}

722. Adams, J. Index Villaris. 1690.

723. Bartholomew, J. G. The Survey Gazetteer of the British Isles. I904.

724. Blackie, C. Geographical Etymology: A dictionary of place-names. Edinburgh, 1887 .

725. Charnock, R. S. Local Etymology: A derivative Dictionary of Geographical Names. 1859. 726. EgLI, J. J. Nomina Geographica. I893.

727. Gomme, G. L. The Gentleman's Magazine Library. English Topography. 1891, etc.

728. Lewis, S. A topographical Dictionary of England. I 849 .

729. - A topographical Dictionary of Wales. 1849. $729 \mathrm{~A}$. - A topographical Dictionary of Scotland. 1846. 730. A topographical Dictionary of Ireland. 1842. 731. Lippincott. New gazetteer of the World (ed. A. and L. Heilprin). 1906.

732. Longman's Gazetteer of the World (ed. G. G. Chisholm). Ig02.

733. Population Returns for Great Britain : Abstract of, I83I. (Parl. Accts. and Papers, Vols. XXXVI,-XXXVIII.) $\quad$ I833.

(d) Atlases.

734. McClure, E. Historical Church Atlas. 1897.

735. Poole, R. L. (ed.). Historical atlas of Modern Europe from the decline of the Roman Empire. $1896-7$. 


\section{Section III.-General Authorities.}

\section{HISTORIES OF THE WORLD OR CIVILISATION.}

736. BüCHER, K. Die Entstehung der Volkswirtschaft. Tübingen, 1904 .

737. Driault, E. Vue generale de l'histoire de la civilization. Paris, 1909.

738. Lavisse, E., et Rambaud, A. Histoire Générale du IVe siècle jusqu'à nos jours. Paris, 1893-1901.

739. Seignobos, C. Histoire de la Civilisation au moyen-âge et dans les temps modernes. Paris, 1893. Trsl. 1908.

740. Williams, H. S. Historians' History of the World. 1907.

\section{HISTORIES OF CONTINENTS OR REGIONS.}

741. Bury, J. B. History of the Later Roman Empire from Arcadius to Irene. (395 A.D. to 800 A.D.) I 889.

742. Chisholm, G. G. Europe (included in Stanford's Compendium of Geography and Travel). 1902, etc.

743. Cunningham, W. Western Civilisation. I8981900.

744. Goldschmid, L. Handbuch des Handelsrechts. Stuttgart, 1891 .

745. Hassall, A. A Handbook of European History. (476-1871). 1902.

746. HeYD, W. Histoire du commerce du Levant au moyen-âge. Leipzig, 1885-6.

747. Meitzen, P. A. Siedelung und Agrarwesen, etc. Berlin, I 895 .

748. Robinson, J. H. Introduction to the History of Western Europe. Boston, 1904. 
749. Schaube, A. Handelsgeschichte der Romanischen Völker des Mittelmeergebiets bis zum Ende der Kreuzzüge. Munich and Berlin, I906.

750. Schultz, A. Das häusliche Leben der Europäischen Kulturvölker vom Mittelalter bis zur zweiten Hälfte des XVIII Jahrhunderts. Munich and Berlin, 1903.

751. Thatcher, O. J., and Schwill, F. Europe in the Middle Ages. 1897 .

\section{HISTORIES OF EPOCHS (The Middle Ages).}

752. GRUPP, G. Kulturgeschichte des Mittelalters. Paderborn, I907, etc.

753. Lodge, R. The Close of the Middle Ages (I 273-I494). I902.

754. Loserth, I. Geschichte des späteren Mittelalters, I I 97-I492. Munich and Berlin, I903. 755. Oman, C. W. C. The Dark Ages (476-918). 1903. 756. Souttar, R. Short History of Mediæval Peoples. 1907.

England.

\section{NATIONAL HISTORY.}

758. Ramsay, Sir J. H. The Foundations of England (B.C. 55-A.D. II 54). 1898.

758A. - The Angevin Empire (I I54-I 216). 1903.

759. - The Dawn of the Constitution (1216-1307). 1908.

760. - The Genesis of Lancaster (1307-I399). [In the press.]

761. Lancaster and York (1399-1485). Oxford. 1892.

Scotland.

762. Brown, P. Hume. History of Scotland. (Cambridge Historical Series.) Cambridge, I 899I909. 
763. Cunningham, W. Presidential Addresses in Trans. R. Hist. Soc. 1911 , etc.

764. Innes, C. Scotland in the Middle Ages. Edinburgh, 1860 .

765. Mackenzie, W. C. History of the Outer Hebrides. Paisley, 1903.

766. Mackintosh, J. The History of Civilisation in Scotland. Paisley, $1892-96$.

767. Patrick, R. W. Cochran. Medixval Scotland. Glasgow, 1892 .

768. Ridpati, G. The Border History of England and Scotland. Berwick, $\mathbf{1} 848$.

Ireland.

769. GrEen, A. S. The Making of Ireland and its Undoing (I200-1600). 1909.

770. Halliday, C., and Prendergast, J. R. Scandinavian Kingdom of Dublin. I 884 .

771. Joyce, P. W. A short History of Ireland to I608. 1893 .

772. - A Social History of Ancient Ireland. 1903.

Wales.

773. Litrle, A. G. Mediæval Wales. 1902.

774. Rhys, Sir J., and Brynmor-Jones, Sir D. The Welsh People. 1906.

775. Walter, F. Das alte Wales : ein Betrag zür Völker-, Rechts-, und Kirchen-Geschichte. Berlin, 1859.

Channel Islands.

776. Pegot-Ogier, E. Histoire des Iles de la Manche, Jersey, Guernesey, Aurigny, Serck. Paris, I88I.

France.

777. Lavisse, E. Histoire de France jusqu'à la Révolution. Paris, 1900-II. 
Flanders.

778. Kervyn de Lettenhove, Baron H. M. B. L. Histoire de Flandre. Bruges, Brussels, 1874. 779. Pirenne, H. Histoire de Belgique. Brussels, I900-3.

780. Vanderkindere, L. Le Siècle des Artevelde.

Etudes sur la civilisation morale et politique de la Flandre et du Brabant. Brussels, 1879. 781. Warnkoenig, L. A. Flandrische Staats-und Rechtsgeschichte bis zum jahre I 305. Tübingen, 1835-42. (Translated by A. Gheldolf. Histoire de la Flandre et de ses institutions civiles et politiques jusqu'à l'année, 1305. Brussels, $1835-6$.)

The Holy Roman Empire.

782. BRYCE, J. The Holy Roman Empire. 1904. 783. Fisher, H. A. L. The Mediæval Empire. 1898. 784. Giesebrecht, W. Geschichte der deutschen

Kaiserzeit. Brunswick, I873-95.

785. Koenler, G. Die Entwickelung des Kriegswesens und der Kriegführung in der Ritterzeit von Mitte des I I Jahrhunderts bis zu den Hussiten-Kriegen. Breslau, 1886-90.

786. Luschin v. Ebengreuth, A. Oesterreichische Reichsgeschichte. Vol. I. Bamberg, I895. 787. RüBeL, KaRL. Die Franken, ihr Eroberungs und Siedelungsystem im deutschen Volkslande. Bielefeld u. Leipzig, I904.

788. Tout, T. F. The Empire and the Papacy, 918-

1273. 1903. (See No. 755.)

789. Voigt, I. Geschichte Preussens. Königsberg, 1827-39.

790. Waitz, G. Deutsche Verfassungsgeschichte. Berlin, I880-2.

The Papacy.

791. Balzani, U. The Popes and the Hohenstaufen, 1889. 
792. Creighton, M. A history of the Papacy (13781527). 1897.

793. Pastor, L. Geschichte der Päpste seit dem Ausgang des Mittelalters. Freiburg-i-B., 1901 , etc.

Italian States.

794. Bent, J. T. Genoa. I881.

795. Brown, H. R. F. Venice. 1893.

796. Carden, R. W. City of Genoa. 1908.

797. Chalandon, F. Histoire de la dominion Normande en Italic et en Sicile. Paris, 1907.

798. Duffy, B. Tuscan Republics. (Story of the Nations.) 1892 .

799. Gregorovius, F. Geschichte der Stadt Rom im Mittelalter. Stuttgart, Berlin, 1903-8.

800. Grisar, H. Geschichte Roms und der Päpste im Mittelalter. Freiburg-i-B., 1901.

801. Hunt, W. Italy. 1907.

802. Molmenti, P. Venice. (Trans. H. R. F.

Brown.) 1906-8.

803. Rössler, O. Grundriss einer Geschichte Roms im Mittelalter. Berlin, I909, etc.

804. Villari, P. Mediæval Italy, from Charlemagne to Henry VII. I9IO.

805. - The two first centuries of Florentine History (translated by Linda Villari). I90I.

Peninsular Kingdoms.

806. Altamira y Crevea, R. Historia de España y de la Civilizacion Española. Barcelona, I 909, etc. 807. Burke, U. R. History of Spain. 1900. 808. Poole, S. L. The Moors in Spain. 1887. 809. Stephens, H. M. Portugal. 1908.

Scandinavian Kingdoms.

810. Allen, C. F. Histoire de Danemark. Copenhagen, 1878 .

8II. Boyesen, H. H. A history of Norway. 1900. 
812. Munch, P. A. Det norske Folks Historie. Christiania, I852-63.

8 I3. SARS, J. E. W. Udsigt over den norske Historie. Christiania, 1905.

814. Cronholm, N. N. A history of Sweden. Chicago, 1902. P.P.

\section{SPECIAL BRANCHES OF HISTORY.}

Political.

815. Hunt, W., and Poole, R. L. Political History of England, I905, etc. ; Hodgkin, T., Vol. I., to 1066 (1906); Adams, G. B., Vol. II., 1066I 216 (1905); Tout, T. F., Vol. III., I 216 -1 377 (1905); Oman, C., Vol. IV., I377-1485 (1906).

Constitutional and Legal.

816. Brunner, H. Geschichte der Englische Rechtsquellen im Grundriss. Leipzig, I909.

817. Holdsworth, W. S. History of English Law. 1903 (in progress).

818. Petit-Dutailis $\mathrm{C}_{\mathrm{H}}$. Studies and Notes supplementary to Stubbs' Constitutional History down to the Great Charter. Manchester, I908. (Ch. VIII.)

8ig. Pollock, Sir F., and Maitland, F. W. The history of English Law before the time of Edward I. Cambridge, I898.

820. Select Essays in Anglo-American Legal History. Cambridge, U.S A., 1907.

821. Stubis, W. The Constitutional History of England. Vol. I., I897; Vol. II., I896; Vol. III., I 895 .

Ecclesiastical.

822. Bellesheim, A. History of the Catholic Church in Scotland (trans. by D. O. Hunter Blair). I887-90. 
823. Stephens, W. R. W., and Hunt, W. History of the English Church, 1899; Hunt, W., Vol. I., 597-1066 (1899); Stephens, W. R. W., Vol. II., 1066-1 272 (1901); Capes, W. W., Vol. III., $14^{\text {th }}$ and $15^{\text {th }}$ centuries (1900).

Naval and Military.

824. Clowes, W. L. The Royal Navy. Vol. I. (to 1603). 1897.

825. Nicolas, Sir N. H. A history of the Royal Navy, to the wars of the French Revolution. (Vols. I. and II., to 1422 .) 1847 .

826. Oman, C. W. C. History of the Art of War. The Middle Ages from the $4^{\text {th }}$ to the $14^{\text {th }}$ century. 1898.

Economic and Social.

827. Ashley, W. J. Introduction to English Economic History and Theory. Vol. I. I 892.

828. Cheyney, E. P. Industrial and Social History of England. New York, I901.

829. Cunningham, W. The growth of English Industry and Commerce during the Early and Middle Ages. 1910.

830. DAY, C. A History of Commerce. 1907.

831. HEYD, W. Beiträge zur Geschichte deutschen Handels. Stuttgart, I890.

832. Inama-Sternegg, K. T. v. Deutsche Wirtschaftsgeschichte bis zum Schluss der Karolinger Periode. Leipzig, I 879-1901.

833. Köтzscкhe, R. Deutsche Wirtschaftsgeschichte bis zum I7 Jahrhundert. A. Meister's Grundriss der Geschichtswissenschaft. Leipzig, 1906.

834. Kowelewsky, M. M. Die ökonomische Entwicklung Europas bis zum Beginn der kapitalistischen Wirtschaftsform. Berlin, 1901-5.

835. Lamprecht, K. Deutsches Wirtschaftsleben im Mittelalter. Leipzig, 1886. 
836. Noes, O. Histoire du commerce du monde. Paris, I89I-I906.

837. Ochenkowski, W. von. Englands Wirtschaftliche Entwickelung im Ausgange des Mittelalters. Jena, I 879 .

838. SchмоlLeR, G. Grundriss der allgemeinen Volkswirtschaftslehre. Leipzig, I90 I-4.

839. Traill, H. D., and ManN, J. S. Social England.

Vol. I., to I273 (1901); Vol. II., 1274-1509 (I902).

Local.

840. PAge, W., and Doubleday, H. A. Victoria History of the Counties of England. 1900, etc. (With an introductory Guide.)

841. WebB, S. AND B. English Local Government from the Revolution to the Municipal Corporations Act. 1906-8.

Gives, incidentally, the best account of the origins of many local institutions.

Dictionaries and Encyclopadias.

842. Chéruel, P. A. Dictionnaire historique des institutions, mœurs et coutumes de la France. Paris, I 899.

843. Chretien-Lalanne, M. L. Dictionnaire historique de la France. Paris, 1872.

844. Dictionnaire topographique de la France. Min. de l'Instruction Publique. Paris, 1861, etc.

845. Franklin, A. Dictionnaire historique des Arts, Métiers et Professions exercés dans Paris depuis le treizième siècle. Paris, Leipzig, 1906.

846. HAYDN, J. Dictionary of Dates, revised, 1906.

847. JАсов, G. New Law Dictionary, 1729. (T. E. Tomlins, 1835).

848. Mackenzie-Wallace, Sir D., Hadley, A. T., and Снisнolm, H. Encyclopædia Britannica. I9IO. 
849. Palgrave, R. H. I. Dictionary of Political Economy. 1894-9.

850. Phillips, L. B. Dictionary of Biographical Reference. 1889.

851. Wetzer, H. J., und Welte, B. Kirchenlexicon oder Encyklopädic der Katholischen Theologie und ihrer Hilfswissenschaften. Freiburg in B., 1886-1903. 



\section{Part II.-The Sources of Medieval. ECONOMic History.}

\section{Section I.-Englanid.}

\section{Division 1.-PUBLIC RECORDS.}

Down to the middle of the Victorian period the English Records and State Papers were chiefly consulted for legal, topographical or genealogical purposes. Even in the present day this aspect of the archives is more conspicuous than that of historical or archrological research. At the same time, though the historical student and the antiquary are much in evidence in the modern archives (owing to the new facilities for investigation suggested by the official series of Calendars and Indexes), the study of economic sources has perhaps been pursued with less assiduity than that of the political and constitutional documents.

The value of the archives as materials for mediæval Economic History is, however, very great, while the extent of these materials is almost incalculable. They include not only many classes of the mediæval records, but also numerous specimens of manorial muniments which have come into the custody of the Crown. Although they have been freely used by economic historians, these materials are still in need of further identification as a necessary preliminary to a complete description, which is more urgently needed than a casual and picce-meal publication of the sources.

The difficulty of making an economic survey of the records is largely due to the artificial plan of their classification. Moreover, while their economic interest is recognised in the fow record texts already 
published, it is practically ignored in the Indexes to the official Calendars and Lists. It becomes necessary, therefore, to concentrate our attention upon certain types of records which are obviously of economic interest. For the purpose of identifying the documents of which we are in search we may utilise a plan of classification whereby the scattered types of official instruments that recur in the records of the ancient courts, together with the membra disjecta known as "Miscellanea" or "Various" or "Special Collections," are brought together in the several forms of Charters, Inquisitions, Accounts, or Pleadings.

It must be remembered that the various Diplomatic Documents and Ministerial or Judical Proceedings included in this structural classification will be found distributed throughout the Courts of Chancery, Exchequer, King's Bench and Common Pleas, with their several departments, as well as throughout the special or abolished jurisdictions such as the Palatine, Admiralty, and Palace Courts; and each of these collections will be consulted in turn as a matter of course. Further, it is suggested that a careful observation of the outward form of the documents is useful for the purpose of identification. The records will be found to take the shape of rolls, books, and loose membranes or pieces of parchment, which usually denote the character of enrolments or originals respectively. The relationship between these forms is of considerable interest, and a careful observation of this general disposition will enable the student to avoid duplication or to supply defects in a particular series. It will also enable him to supplement the final Record by intermediate forms containing fuller details.

It has been already mentioned that this scheme of structural classification has been utilised here for both published and unpublished records. It must be 
observed, however, that the scope of this work does not permit of the enumeration of individual Record publications in the shape of texts, calendars, and lists or indexes, even if these were in all cases useful for the present purpose. Moreover, a list of serial publications is given in an Appendix. It may also be remarked that, besides the complete or partial editions noted or referred to below, many important extracts or abstracts of documents have been cited in modern works like those of Seebohm, Vinogradoff, Pollock and Maitland, Round, etc. (See below, Part III.) It should be noted further that in the official publications of the Record Commission and Rolls Series, the titles List, Index, and Calendar are used interchangeably.

\section{A.-DIPLOMATIC DOCUMENTS.}

I.-Official Instruments.

\section{(a) Royal Charters and Confirmations.}

The originals of the Anglo-Saxon charters (which include many vernacular Writs and Wills, etc.) are not now in official custody. (See below, Division II.) The same remark applies to most of the registers or cartularies containing later copies. Some later enrolments, however, are found in the Chancery Rolls, though these have rarely been used in the printed editions cited below (Nos. 1074 seq. passim). Several charters that are not included in the printed editions will be found in the collections of facsimiles published by the Ordnance Office and British Museum. For modern works indicating the economic value of these charters, see Nos. 1873, etc. In general, they supply information with regard to the distribution and tenures of land, and to franchises and privileges, such as exemption from taxation, with incidental notices of the agrarian cconomy.

Comparatively few original charters of the AngloNorman period have survived in official custody, and 
these will be found amongst the Records of the Duchy of Lancaster and the Special Collection of "Ancient Deeds." The charters of Henry II. have been recently described by M. L. Delisle (Bibliothèque de l'Ecole des Chartes, t. 67), and a Codex Diplomaticus for the whole period (including the continental issues), is in preparation by Mr. C. W. Davis and Prof. C. Haskins. Special reference may be made to the notes of Nos. 852 and 1381. Occasionally Anglo-Norman charters are found enrolled in Chancery Rolls of a later date (Rotuli Chartarum [ed. Hardy] and the Calendars of Patent Rolls); but a still larger number are entered in private cartularies (see below, Section II.). Many of these charters are really writs. In point of economic interest, these charters illustrate the devolution of feudal tenures and the evolution of constitutional liberties, such as freedom of trade. They also elucidate the position of the Forests and of the Church Lands.

The originals of what may be called Conventional Charters (1200-1485) are only found amongst the miscellaneous documents casually deposited in the Archives (Ancient Deeds and Original Letters Patent). A regular series of enrolments is preserved in the Chancery Rolls, and a certain number are entered in official precedent books. As these charters were chiefly issued in connection with grants of Markets, Fairs, Warrens, Feefarms, and other fiscal concessions, their economic interest is well defined. During the greater part of this period, however, grants made by Letters Patent usurped many of the functions of earlier Royal Charters. The bibliography of this section is extensive, but is chiefly based upon muniments preserved in private collections. For publications, see below, Nos. 852, sq.

Very few Royal Confirmations exist for the AngloSaxon period, and those for the Anglo-Norman period are not easily distinguishable from original charters. From 1225 onwards Confirmations by Inspeximus 
are enrolled indiscriminately in the Charter and Patent Rolls, and a regular series of Confirmation Rolls begins only in 1483 .

Apart from the question of their general authenticity, the Confirmations are of considerable economic interest. For a further description, sce Nos. 856 and 860.

852. Ancient Charters, Royal and Private [1095-1200] (J. H. Round). Pipe Roll Soc. 1888.

853. London School of Economics. Formula Book of English Official Historical Documents ( $\mathrm{H}$. Hall). Pt. 1. 1908.

854. Lancaster, Duchy of: Charters of the (W. Hardy). I845. See No. 862.

855. Record Commission. Calendarium Rotulorum Chartarum, etc. [1199-1483]. 1803 .

856. Rotuli Chartarum [1199-1216] (T. D. Hardy). 1837 .

857. - Originalia Rolls. [Rotulorum Originalium Abbreviatio.] 1805 .

858. - Statutes of the Realm. Vol. I. I810.

859. Record Office. Calendar of the Charter Rolls. 1903, etc.

860. Cartac Antiquae, Table of references to Charters in the, and Confirmation Rolls of Chancery. Ethelbert to James I. (DeputyKeeper's Report, XXVII., App. No. 2.). 1866. 861. - Royal Charters, Calendar of. (DeputyKeeper's Reports, XXIX. and XXX.). 1868, 1869.

862. Lancaster, Duchy of, Royal Charters, William II. to Richard II., Calendar of. (Deputy-Keeper's Report, XXXI.). 1870.

863. - Deputy Kceper's Reports, II., III., VIII., XX., XXI., XXVII., XXIX.-XXXI., XXXV., $X X X V I$. Inventories and Calendars of Charters, Chartularies, Inrolments, etc. 


\section{(b) Writs and Letters under the Great Seal.}

The Writs in question, as far as they are of economic interest, are usually included amongst the Royal Charters of the Anglo-Saxon and Anglo-Norman periods (Ioth to I 2 th centuries). The later legal type (Original and Judicial Writs) does not concern us here.

The Letters referred to in the title are Writs of an epistolary character which also show a close assimilation to Royal Charters. The varied interest of the Letters Patent and Close has been frequently described (Nos. $868,870,884)$, and their economic value will be apparent from the printed Calendars (Nos. 889, 896). Besides the above, other instruments, relating to Passage and Exchange, etc., which were formerly classed under separate titles, are now regarded as Supplementary Patent and Close Rolls. With them are included the Treaty Rolls, better known as Gascon, French, Norman, Almain, Scotch, Irish, and Welsh Rolls. The remaining series of Chancery Rolls, which are still separately classified, like the Fine and Redisseisin Rolls, etc., may be regarded as departmental memoranda, and the same remark applies to the Originalia Rolls of the Exchequer which contain copies or abstracts of Royal Grants. Letters Patent or certificates might be issued by certain Departmental Officers, and amongst these Customers" "Cokets" and Wardrobe "Debentures" are of economic interest. The above series of Chancery enrolments may be supplemented in a few particular instances by the "Original Letters Patent" above referred to, and also by Entry Books such as the Libri Munimentorum; but on the whole it is remarkably complete. The Bibliography of this section is also extensive, but the economic aspect has been somewhat neglected. In particular, a separate subject-index to the Rolls Series of mediæval Calendars is needed, whilst the interesting "Treaty," Exchange, Passage, Liberate, Fine, Protection, Staple, and Scutage Rolls are still (19ro) for the most part uncalendared. 
864. Crecy and Calais [1346-47] from the Public Records (G. Wrottesley). Wm. Salt Archaol. Soc. Collections, Vol. XVIII., pt. 2. 1897 .

865. Dugdale, W. A perfect copy of all summons of the nobility to the Great Council. 1685 .

866. Gascon Rolls. Catalogue des rolles gascons, normans, et françois ( $\mathrm{T}$. Carte). London and Paris, 1743.

867. Grants, etc., from the Crown during the reign of Edward V. (J. G. Nichols). Camden Society. 1854 .

868. Gascon Rolls. Rôles gascons, Vol. I., 1242-54 (F. Michel); Supplément and Vol. II. (C. Bémont). Documents Inédits. Paris, 1885, 1896, etc.

869. Liberate Rolls. Extracts from the liberate rolls relative to loans by Italian merchants to the Kings of England (C. G. Young). Archaologia, XXVIII., 207-326. 1840. See No. 878.

870. London School of Economics. Formula Book of English official Historical Documents. Part I, 1908 ; Part 2, 1909.

871. Norman Rolls. Roles normands et français et autres pièces tirées des archives de Londres par Bréquigny. (Société des Antiquaires de Normandie, Mémoires, Vol. XXIII., pt. I.) Paris, Caen 1858 . See also Nos. 866, 868, 873, 879, 894,897 .

872. Norman Rolls. Rôles normands de la Tour de Londres sous Henri V. [1417-1422] (L. d'Anisy). Mem. de la Soc. des Antiq. de Normandie t. XVI. Paris, Caen, 1845 .

873. Parliament Rolls. Rotuli parliamentorum; et petitiones et placita in parliamento, 12781503. 1767-77. Index, 1832 .

874. The Scutage and Marshal's Rolls (S. R. ScargillBird). Genealogist, N.S., I. 65. 1884 . 
875. Record Commission. Close Rolls. Rotuli litterarum clausarum, I 204-27. (T. D. Hardy.) $1833-44$.

See also Record Office.

876. - Documents illustrative of English history in the thirteenth and fourteenth century. (H. Cole). I835-I 844.

877. - Fine Rolls. Excerpta e rotulis Finium, 1216-72. (C. Roberts.) I835-6.

878. - Foedera, conventiones, etc. (T. Rymer.) I816-1869.

879. - Rotuli de Liberate ac de Misis et Praestitis regnante Johanne. (T. D. Hardy). 1844 .

880. - Norman Rolls. Rotuli Normanniae, I 200-I 205 and I4I7-I8. (T. D. Hardy.) 1835. 88I. - Oblate Rolls. Rotuli de Oblatis et Finibus. (T. D. Hardy.) 1835 .

882. Originalia Rolls. Rotulorum Originalium in curia Scaccarii Abbreviatio. 1805-10.

883. - Parliamentary writs and writs of military summons [Edward I.-Edward II.]. (F. Palgrave.) 1827-34.

884. _- Patent Rolls. Rotuli Litterarum Patentium, I20I-I6. (T. D. Hardy.) 1835.

See also Record Office.

885. - Calendarium Rotulorum Patentium 3 John-23 Edward IV. 1802.

886. Rotuli Selecti ad res Anglicas et Hibernicas spectantes. ( $\mathrm{J}$. Hunter.) 1834.

887. - Statutes of the Realm, 1235-1713. (A. Luders, T. E. Tomlins, J. Raithby, and others.) I8I0-28.

888. Record Office. Calendar of Charter Rolls. 1903-8.

889. Close Rolls, Calendar of. 1892, etc. See No. 875 . 
890. Record Office. Royal charters which occur in letters of inspeximus, exemplification, or confirmation, and in cartularies in the Public Record Office, Calendar of. Pt. I. from Ethelbert of Kent to William II. Deputy-Keeper's Report, XXIX. 7-48. 1868.

891. L-Lancaster, Duchy of. Ancient Charters or Grants, Calendar of. Deputy-Keeper's Reports, XXXV-XXXVII. $1874-5$.

892. - Ancient Rolls of the Chancery of the County Palatine, Calendar of. DeputyKeeper's Reports XXXII., XXXIII., XXXVII. $1871-76$.

893. - Patent Rolls, Calendar of. 5 Richard II.-2I Henry VII. Deputy-Keeper's Reports, XL. App. 52I-45. I879.

894. - French Rolls. Calendar of French Rolls

[I Henry V-49 Henry VI]. Deputy-Keeper's Reports, XLIV. 543-638, XLVIII. 217-450. I 883-87.

895. - Norman Rolls. Calendar of Norman Rolls, Henry V. Deputy Keeper's Reports, XLI., App. I. 671-810; XLII., 313-472. I880-81. See Record Commission, Norman Rolls.

896. Patent Rolls. Calendar of Patent Rolls. I891, etc. See No. 884 .

897. Rolls Series. Syllabus of Documents in Rymer's Foedera. (T. D. Hardy.) 1869-85. 898. - Parliamento, Memoranda de, A.D. 1305. (F. W. Maitland.) App. II. 1893.

(c) Writs and Letters under the Smaller Seals (Privy Seal and Signet) or Sign Manual, Epistolary and Notarial Documents.

Instruments under the Smaller Seals should properly be distinguished, according to their purport, as royal missives, or as departmental warrants for procuring the Great Seal. No such division is, however, observed 
in the official classification, and the bulk of the instruments referred to will be found in three extensive series of "Warrants" in the Chancery, Treasury of Receipt, and Exchequer of Receipt collections. These are the originals or rescripts that were filed, no system of enrolment or entry having apparently been practised in the Seal offices, though many instruments were entered in the Exchequer Memoranda Rolls, etc. Amongst the missives are certain letters relating to "Benevolences," and amongst the departmental warrants are files representing the activities of the Household Officers in the fifteenth century. - Not only, however, is the arrangement of the documents in this section incomplete, but their bibliography is practically a blank. No printed lists or calendars exist, and the specimens that have been published in the Rolls Series (Nos. 9r2-9r6), and by M. Déprez (No. 900), are chiefly of political interest. Some that relate to fiscal matters will be found in the footnotes of Madox's History of the Exchequer, and others are printed in the Formula Book (No. 87o).

A large collection of original Papal Bulls and treaties with foreign states and other Diplomatic Documents was carefully preserved in the Treasury of the Receipt (Exchequer), and another collection was preserved amongst the Chancery Records. These documents were also occasionally enrolled, and a large number are entered in the Libri Munimentorum. The Treaty Papers are chiefly notarial instruments. Many of these, together with Papal Bulls, have been printed in the Foedera by the Record Commission (Nos. 907-908), but no complete collection of diplomatic documents illustrating the commercial relations between this country and the medixval continental states has been published. Lists of these will be found in old Reports of the Deputy-Keeper, and those enrolled in the Chancery are calendared (Nos. $889,896)$. They have been more carefully described 
by continental scholars (Gross, Nos, 2117-2121, 2123-24).

For the Papal Bulls the well-known register of Jaffe-Potthast is available (Nos. I607, I608), and for instruments preserved or registered abroad various calendars and texts may be consulted (Nos. 1604, 1625 ).

A large collection of royal and private letters is still preserved under the head of Ancient Correspondence (Chancery). Although the official list (No. 153) is somewhat meagre, it will assist students in discovering subjects of economic interest. The same remark will apply to the list of Ancient Petitions (ibid.), which may be regarded as epistolary instruments. The same remark will apply to certificates and other returns. Instances will be found in the case of the returns to the Inquisitions of Knights' Fees, in the Red and Black Books of the Exchequer and Testa de Nevill, as well as in the Chancery Files. At the same time, the returns to royal writs of inquisitions, etc., can be more conveniently considered under the heads of Ministerial and Judicial Proceedings.

More than one series of Royal Letters has been published from various sources; but these are of less economic value than the private correspondence of merchants and other subjects (No. 899).

The above Diplomatic types are found in the shape either of originals under seal, or of entries in cartularies and other register books. These again may be conveniently distinguished by their provenance (as indicated above), and in each case the cconomic information may be recognised under such subject headings as Pensions, Tithes, Feudal Service, Fisheries, Buildings, Agrarian, and Domestic Economy, and many others which have been briefly indicated in particular instances.

899. Cely Papers, The, 1475-1488 (H. E. Malden). Royal Hist. Soc. 1900. 
900. Etudes de Diplomatique Anglaise [1272-1485] (E. Déprez). Paris, 1908.

901. Les Ambassades Anglaises pendant la Guerre de Cent ans (L. Merot et E. Déprez). Bibliothéque de L'Ecole des Chartes, Vols. LIX.-LXI. I895-1900.

902. Original Letters illustrative of English History (H. Ellis). 1824-1846.

903. Letters of Royal and illustrious Ladies of Great Britain [ I I03-I 558] (A. E. Green). 1846. 904. Letters of the Kings of England (J. O. Halliwell). 1848 .

905. Lettres des rois, reines, et d'autres personnages des cours de France et d'Angleterre depuis Louis VII. jusqu'à Henri IV. (J. J. ChampollionFigeac). Documents inédits. Paris, 1839-47. 906. London School of Economics. Formula Book (ut supra).

907. ReCord Commission. Foedera, Conventiones, litteræ, etc. (T. Rymer). 1816-1869.

908. RECORD OFFICE. Syllabus of Documents in Rymer's Foedera (T. D. Hardy). I 869-85.

909. - Privy Seal Rolls of Edward II. when Prince of Wales, 33 Ed. I. (Deputy-Keeper's Reports, IX., App. II., 246-47.) 1848.

910. Exchequer, Treasury of the Receipt, Calendar of Diplomatic Documents. (DeputyKeeper's Reports, XLV., App. I., 283-380, and XLVIII., App. I., 561-619.) 1885, 1887.

91 I. Lancaster, Duchy of. Privy Seals, Calendar of. (Deputy-Keeper's Reports, XIIII., App. I., 363-70.) 1882.

912. Rolls Series. Royal and Historical Letters during the reign of Henry IV. (F. C. Hingeston). I 860 .

913. Royal and other historical letters illustrating the reign of Henry III. (W. W. Shirley). $1862-6$. 
914. Rolls Series. Letters and Papers illustrative of the Wars of the English in France during the reign of Henry VI. (J. Stevenson). I86I-4.

915. Letters and Papers illustrative of the reigns of Richard III. and Henry VII. (J. Gairdner). 186I-3.

916. - Official correspondence of Thomas Bekynton (G. Williams). $\quad$ r 872 .

917. Viard, J., and Déprez, E. Chronique de Jean le Bel. (Appendix.) r 1904 .

\section{II.-Semi-Official Instruments and Private Instruments Deposited in Archives.}

These include various private Conveyances or Contracts such as Deeds-poll, Indentures, Leases, Quitclaims, Pensions, Recognisances, Bonds, Assignments, Certificates, etc., which have been enrolled or entered in official records, either by way of remembrance of the interests of the Crown or as a matter of privilege and favour to royal officials. They do not include the regular series of Fines. A large number of instruments relating to the financial transactions of Edward I. are entered in the Red Book of the Exchequer, the Libri Munimentorum, and other Books of Remembrance. Similar transactions are referred to in the Chancery enrolments (above A. I.). Official recognizances are chiefly entered in the Exchequer Memoranda Rolls. Some official Indentures are also entered in the Libri Memorandorum. The original instruments will, in many cases, be found amongst the "Ancient Deeds," Exchequer Proceedings, Original Letters Patent, and other "Special Collections," as well as in the Miscellaneous Rolls and Books and the Miscellanea of the several classes of Records. Some of these documents, like Indentures of War, are mixed with the Exchequer Accounts. The certificates under the Statute of Merchants and Statute Staple 
(Series I.) are of especial interest. The value of these semi-official instruments is considerable in connection with fiscal history. Their bibliography, however, is disappointing, except in respect of Jewish "Starrs." Specimens are printed in the Formula Book (No. 92I). The private instruments deposited in archives form a large and miscellaneous class of documents which differs from the preceding in not being enrolled, during the mediæval period, or entered in Books of Remembrance, though a considerable number are entered in Cartularies now preserved in the Record Office, while a few specimens may be found in precedent books. It follows, therefore, that these are original instruments which have been casually acquired in the course of litigation, or through the feudal intervention of the Crown. They include various forms of conveyances, contracts and certificates, such as Feoffments, Confirmations, Demises, Mortgages, Wills, Manumissions, Exchanges, Partitions, Rent-charges, Pensions and Corrodies, Quit-claims, Concords, Uses, Bonds, Indentures, Letters of Attorney, Assignments, Acquittances, etc. Their economic interest is considerable, and some progress has been made in the description of the several series under which they have been arranged through the well-known "Calendar of Ancient Deeds" (No. 923). A distinct series connected with the Greenwich Hospital Department of the Admiralty is described in a manuscript list. Reference should again be made to the official Guide under the heading "Deeds."

918. Ancient Charters, Calendar of (J. Ayloffe). 1774. 919. Formulare Anglicanum (T. Madox). 1702.

920. Jews (English), Hebrew Deeds of [1 1 82-1290] (M. D. Davis). 1888. See No. 926.

921. London School of Economics. Formula Book. Pt. I. 1908.

922. Record Commission. Ancient Kalendars, etc., of the Exchequer. (F. Palgrave.) I 836 . 
923. Record Office. Ancient Deeds in the Public Record Office, Descriptive catalogue of. 1890 1900.

924. Monastic and other cartularies in the Public Record Office, Calendar of. Deputy-Keeper's Report, VIII., App. IV., 135-166. 1847.

925. Rolls Series. Red Book of the Exchequer (H.

Hall). 1896. Vol. I., Table of Contents.

926. Selden Society. Jews, Exchequer of. Select

Pleas, Starrs, and other records from the Rolls of, 1220-1284. (J. M. Rigg.) 1902.

\section{B.-MINISTERIAL PROCEEDINGS.}

\section{(a) Royal Surveys, Inquisitions, and Assessments.}

Of these the Surveys may be regarded either as returns to special processes of the Chancery or Exchequer, or as ordinary manorial extents preserved in official custody. In either case they are chiefly concerned with the agrarian economy of manors or lands.

The Inquisitions may be conveniently distinguished (see Formula Book, Pt. 2, Table of Contents) as Fiscal and Feudal respectively. The former, which are not all preserved in official custody, include the well-known Hidage and Carucage assessments of the IIth and I 2 th centuries. Most of these have been exhaustively described and printed; but some obscurity still exists with regard to local assessments. The latter are of institutional rather than of agrarian interest, and some closely resemble Royal Accounts in their general form. These Inquisitions are preserved either in the form of original returns filed with the writs of Inquisition, or as copies of the same entered in official registers, as in the case of Domesday with its satellites and many of the great inquests of the 12th and 1 $3_{\text {th }}$ centuries (Nos. 927, sq.). In a few cases the official entries are made up in the form of rolls. In some instances fragments of the original returns have survived. These are always instructive, and they are 
often valuable in respect of details which are not given in the official registers. Assessments are frequently regarded as Revenue Accounts, which they closely resemble in form. They may be distinguished, however, by the raison d'être of their compilation, being returns to a writ or order which influences the form of composition, as in the well-known cases of the Inquisitiones Nonarum, the Taxatio Ecclesiastica, the Valor Ecclesiasticus, and Parliamentary Subsidies. References to the above types of records will be found in the official Guide under the headings "Accounts," "Subsidies," etc.

Most of the existing MSS. of the so-called " satellites of Domesday Book," as well as copies or excerpts from other royal inquisitions, are preserved in public libraries or private collections. Many specialised editions of royal surveys and inquisitions for particular counties will be found in the Transactions of local societies (Nos. 927, sq.). For a detailed bibliography see Davenport, pp. vii.-xi. and 18-29, Moore, Bibliographies (No. 138), and Gross, sections 50 ( $a$ and b), 55, $56(b), 57$; but a very large number of "Ancient Extents," preserved amongst the Public Records, is still unpublished. Inventories and indexes of the Inquisitions, Post Mortcm, Ad quod Damnum, etc., have been produced by the Record Commissioners and the Master of the Rolls.

(i) Domesday and its Satellites.

927. [Cambridgeshire.] Inquisitio Comitatus Cantabrigiensis; subjicitur Inquisitio Eliensis (N. E. S. A. Hamilton). Royal Society of Literature. 1876. 928. Devonshire Domesday, and geld inquest. ( $\mathrm{J}$. B. Rowe, etc.). Devon Assoc. for Advancement of Science, etc. 1884-92. See No. 943.

929. Domesday Book. Facsimile. Ordnance Survey Office. I 86I-4.

See also No. 942. 
930. [Durham.] Boldon Buke. A survey of the possessions of the See of Durham (W. Greenwell). Surtces Soc. 1852.

See also No. 94 t.

931. Ipswich, Great Domesday book of. Liber sextus (C. H. E. White). 1885.

932. Kent, The Domesday book of (L. B. Larking). 1869.

933. Leicestershire Survey, The (trans. F. M. Stenton). Victoria Co. Hist. of Leicestershire, I., 339. 1907.

934. (J.H. Round). Feudal England,p. 197. I 895. 935. - (trans. W. K. Boyd). Leicestershire Archit. and Archaol. Soc. Trans., VIII., 179. 1896.

936. Lincolnshire and Rutlandshire, Domesday book of (G. Smith) [trans. only]. 1870.

937. Lincolnshire Survey, The, temp. Henry I. (J. Greenstreet). I 884 .

938. Lindsey Survey, The (J. H. Round). Feudal England, 181-95. 1895 .

939. Northamptonshire Survey (J. H. Round). Op. cit. 215-24. 1895 .

940. Northamptonshire Survey, The (J. H. Round). Victoria County History of Northamptonshire, I., 357. 1902.

941. Record Commission. Boldon Buke. Domesday Book, IV., p. 565. 1816.

942. -Domesday Book. I 783 , etc.

943. Exon Domesday, The (H. Ellis). Domesday Book, IV., I-493. 1816.

944. - Inquisitio Eliensis. Domesday Book, IV., 494-528. 1816.

See also No. 927.

945. Liber Winton (H. Ellis). Domesday Book, IV., 529-62. 1816 .

946. - Northamptonshire geld roll (H. Ellis). Introduction to Domesday Book, I., I 84-7. 1833 . Sec above Nos. 939-40. 
947. [Somerset.] Domesday Studies: Analysis and digest of the Somerset survey and of the Somerset gheld inquest of 1084 as collated with Domesday (R. W. Eyton). 1880.

948. Staffordshire Survey, Domesday Studies: An analysis and digest of the (R. W. Eyton). $188 \mathrm{I}$.

949. Sussex, Domesday Book in relation to the county of (W. D. Parish). Sussex Arch. Soc. 1886.

950. Wiltshire, Domesday for (with translations, W.H. Jones). Bath. I865.

951. Worcestershire Surveys, Some early (J. H. Round). Victoria County History of Worcestersbire, I., 324-31. I901.

(ii) Fiscal Inquisitions and Assessments.

952. Assessments in Kent for the aid to knight the Black Prince, 20 Edward III. (J. Greenstreet). Archaologia Cantiana, X. 1876.

953. Assessment of Norfolk for tenths and fifteenths in 1334, with deductions made in 1449 (W. Hudson). Norfolk Archaology, XII. 1895.

954. Colchester Assessment Rolls for 24 and 29 Edward I. Rolls of Parliament, Pt. I, Appendix.

955. Record Office. Feudal Aids, Inquisitions and Assessments relating to (1284-I43I). I899, etc.

(iii) Feudal Inquisitions.

956. Kirkby's Inquest for Yorkshire (R. H. Skaife). Surtees Soc. 1867.

957. Liber niger scaccarii. (T. Hearne). I77I ; reprinted 1774 .

958. Record Commission. Ducatus Lancastriae calendarium inquisitionum post mortem. Edward I-Charles I. I 827-34.

959. - Hundredorum Rotuli. (Temp. Henry III. and Edward I.) 1812-18.

960. - Nonarum Inquisitiones. 1807. 
961. Record Commission. Inquisitiones ad quod dainnum, et calendarium rotulorum chartarum. 1803.

962. Nomina Villarum. (F. Palgrave.) Parliamentary Writs, II., div. III., 301-406. 1834 . 963. Placita de quo Warranto. (W. Illingworth.) 1818 .

964. - Testa de Nevill. (Richard I.-Edward I.). 1807.

965. Record OfFice. Feudal Aids, 1284-1431. 1899, etc.

966. Kirkby's Quest 1284-5. (Printed in Feudal Aids, 1284-1428.) 1867.

967. - Inquisitions post mortem. - . , Calendar of. 1898 , etc.

Separate texts or calendars of Inquisitions for particular counties have been published by local societies, e.g., for Lancashire, Worcestershire, Gloucestershire, Shropshire, Dorset, Lincolnshire, Wiltshire. See Appendix.

968. Rolls Series. Exchequer, Red Book of the. (H. Hall.) 1896.

969. Rotuli de dominabus et pueris et puellis de donatione regis in XII. comitatibus [3I Henry II.] (Stacey Grimaldi.) I830.

(iv) Ecclesiastical Inquisitions.

970. Record Commission. Taxatio ecclesiastica Angliae et Walliae auctoritate Nicholai IV. I802. 971. Valor Ecclesiasticus, temp. Henry VIII. I 8 ro.

972. A Subsidy collected in the Diocese of Lincoln in 1526. (H. E. Salter.) 1909.

973. Subsidy collected from the clergy of Sussex. (W. H. Blaauw). Sussex Arch. Soc. Collections, V. 1852 .

(b) Royal Accounts.

Although this class of documents is apparently homogeneous in character, considerable difficulty is sometimes experienced in distinguishing between 
Accounts and Surveys, or even Inquisitions and Assessments. Again, it will be found that in the case of Accounts a considerable difference exists in point of detail between the originals and the official abstracts which usually take the form of enrolments instead of entry books. The original Accounts, like the original Inquisitions, are now preserved in a fragmentary condition, and the most perfect series is contained in the enrolments. Although the great majority of both series has been preserved in the Exchequer, isolated specimens may be found in the records of the Chancery and other Courts. References to Accounts appear in the official Guide under that heading. The bibliography in relation to the bulk of this class is meagre compared with that of the preceding class. It includes extracts from the Pipe Rolls, the Book of Aids, Poll Taxes and Subsidies, etc., printed in antiquarian journals, etc. For details, see Gross, section $50 \mathrm{c}-\mathrm{f}, \mathrm{h}$, Davenport pp. x. and I4-I 5, and Moore, op. cit. Index, s.v. "Subsidies." 974. Accounts, Chester Chamberlain's (R. StewartBrown). Lancashire and Cheshire Record Series. 1910.

975. Accounts of the expense of the Great Wardrobe of Edward III., I344-49 (N. H. Nicolas). Archeologia, XXXI. I846.

976. Accounts, Wardrobe of Edward IV. and Privy Purse expenses of Elizabeth of York. (N. H. Nicolas). 1830.

977. Aid (The) levied in Gloucestershire in 20 Edward III. [to knight the Black Prince] (J. Maclean). Bristol and Glouc. Arch. Soc. Trans., X. I 886. 978. Aid taken 20 Edward III., Extracts from the Liber Niger and the account of the (J. R. Daniel Tyssen). Norfolk Antiq. Miscellany, I. 1877 .

979. Deodands, Yorkshire, in the reigns of Edward II. and III. Torkshire Arch. Soc. Fournal, XV. 1900 . 
980. Halr, H. Formula Book of English Official Historical Documents. Pt. 2. 1909.

981. Honor and forest of Pickering (R. B. Turton). North Riding Rec. Soc., new series, IV. 1897. 982. Inventory of Crown Jewels in the King's Wardrobe, 3 Edward III. (C. Ord). Archeologia, X.

1792.

983. Issues of the Exchequer (F. Devon). (Henry III.James I.) 1792.

984. Issue Roll of Thomas of Brantingham, 44 Edward III. 1370. (F. Devon.) 1835.

985. Liber quotidianus contrarotulatoris garderobae, 28 Edward I., 1299-1300. Soc. of Antiq. of London. 1787.

986. Liberate Rolls, Extracts from the relative to [the repayment of] loans supplied by Italian merchants to the kings of England in the thirteenth and fourteenth centuries (with an introductory memoir by E. A. Bond, ed. C. G. Young). Archeologia, XXVIII. 1840.

987. Magni Rotuli Scaccarii Normanniae. ( $T$. Stapleton). 1840 , etc.

988. Pipe, Great Roll of the, for the fifth year of Henry II., et seq. Pipe Roll Society. 1884, etc.

See also below under Record Commission.

989. Pipe Rolls of Cumberland, I222-1260 (F. H. M. Parker). Cumberland Antiq. Soc. 1905.

990. Pipe Rolls for Cumberland, Westmorland, and Durham during the reigns of Henry II., Richard I. and John. Soc. of Antiq. of Newcastle-on-Tyne. 1847.

991. Pipe Rolls of Henry II., relating to Devon, Extracts from (O. J. Reichel). Transactions of the Devonshire Association, XXIX. 1897.

992. Pipe Rolls for Dorset [ I $30-1210$ ] (W. M. Barnes). Dorset Nat. Hist. and Antiq. Field Club Proceedings. $1893-8$. 
993. Pipe Rolls, Lancashire, I $217-18$, I 26I-2 (in Calendar of Lancashire Assize Rolls, App. II.). Lancashire and Chesbire Record Society Publications, XLVII., XLIX. 1903-5.

994. Pipe Rolls, Northumberland, I I 29-I 272 (in J. Hodgson's History of Northumberland, pt. 3, Vol. III.). I 820-58.

995. Pipe Roll for Northumberland, 1273-84 (W. Dickson). $1854-60$.

996. Pipe Rolls of Nottingham and Derby, Extracts from the [II3I-I307]. (Reprinted from Feudal History of the County of Derby, J. P. Yeatman.) 1886.

997. Pipe Rolls, Staffordshire [1130-1216] (R. W. Eyton). William Salt Arch. Soc. Collections, I.-II. I88I-2.

998. Pipe Rolls, Wiltshire, temp. Henrici II. [I I 59I 179] (Thomas Phillipps). Middle Hill Press. 1853 .

999. Poll Tax, A Bath, 2 Richard II. (E. Green). Bath Nat. Hist. and Antiq. Field Club Proceedings, VI. 1889. See Subsidies.

1000. Poll Tax Account for Cornwall, I377 (J. Maclean). Royal Institution of Cornwall Fourn. IV. 1872.

I00I. Poll Tax for the town and liberties of Shrewsbury, 1380 (W. G. B. Fletcher). Sbropsbire Arch. and Nat. Hist. Soc. Trans., 2nd series, II. 1890.

1002. Poll Tax of 2-4 Richard II., 1379-81 [Staffordshire] (W. Boyd). William Salt Arch. Soc., XVII. 1896.

1003. Poll Tax of I38I, Suffolk return for the (E. Powell). Royal Hist. Soc. Transactions, new series, VIII. 1894. See also East Anglian, 3rd series, V., 369. 1894 .

1004. Poll Tax Returns of the East Riding of Yorkshire, 4 Richard II. (E. Lloyd). Yorkshire Arch. Fournal, XX. I909. 
1005. Poll Tax of 1379, Returns for the West Riding [of Yorkshire]. Reprinted from Yorkshire Arch. and Topog. Assoc. Fournal, V., VI., VII., IX. I882.

1006. Powell, E. The Rising in East Anglia in 1381 .

[Poll Tax returns for East Anglia in Appendix.] 1896.

See No. 1003 .

1007. Proceedings of His Majesty's Commissioners on the Public Records, 1832-33 (C. P. Cooper). 1833 .

Excerpts from Wardrobe Accounts of 18 Edward II.

1008. Prynne, W. Aurum reginae. 1668.

1009. Receipt Roll of the Exchequer for Michaelmas Term, II85. (London School of Economics.) 1899.

ioro. Record Commission. Chancellor's Roll, 3 John. 1833 .

1011. - Documents illustrative of English History in the $13^{\text {th }}$ and $14^{\text {th }}$ centuries, from the records of the Queen's Remembrancer $(H$. Cole). 1844 .

1012. Nonarum inquisitiones, temp. regis Edwardi III. 1807 .

1013. - Pipe Roll, 3I Henry I. (J. Hunter). 1833. 1014. - Pipe, Great Rolls of the, 2, 3, 4 Henry II. and I Richard I. (J. Hunter). I 844.

1015. Roll of Expenses of Edward I. in Wales, 128I82 (ed. S. Lysons, with a translation by J. Brand). Archeologia, XVI. I812.

1016. Rotulus Familiae, Extracts from the, anno 18 Edward I. (J. Brand). Archeologia, XV. 1806.

1017. Rotulus Hildebrandi de London et Johannis de Harnham taxatorum et collectorum quintedecime et decime [7 Edward III.]. Wiltes. Middle Hill Press, n.d. 
I018. Scutage and Marshal's Rolls, The (S. R. Bird). Genealogist, new series, I. (Scutage Roll of 6 Henry III.) 1884 .

IOI9. Subsidy Roll of 5 I Edward III. (J. Topham). Archaologia, VII. 1785.

1020. Bath Lay Subsidies, Henry IV.-Henry VIII. (E. Green). Bath Nat. Hist. and Antiq. Field Club Proceedings, VI. I 889.

I02I. Subsidy Rolls (Lay), Cambridgeshire (W. M. Palmer). East Anglian, 3rd series, VIII., and passim. I899-I900.

1022. Subsidies (Lay), Cambridgeshire, I Edward III., I326 (J. J. Muskett). East Anglian, 3rd series, X., XI., and passim. I903-6.

1023. Subsidy Roll (Lay), Derbyshire, in I327-8 (J. C. Cox). Derbyshire Arch. and Nat. Hist. Soc. Journal, XXX. I908.

1024. Subsidy Roll, I 327, Gloucestershire. Middle Hill Press, n.d.

1025. Subsidy Rolls, Gloucestershire, 1327, etc. (in

R. Bigland's Historical Collections relative

to the County of Gloucester, I786, etc.)

1026. Subsidy Rolls, I 327, Lackford Hundred, Suffolk. East Anglian, new series, V. I 893-4.

1027. Subsidies (Lay), Lancashire, Henry III. to Edward IV. Record Soc. for Lancasbire and Chesbire, XXVII. I893.

1028. Subsidy Roll (Lay) for I332, Lancashire (J. P. Rylands). Record Soc. for Lancasbire and Chesbire Miscellanea II. I 896.

1029. Subsidy Roll, Lay, The Earliest, I327, Leicestershire Assoc. Arcbit. Socs. Reports and Papers, XIX. (I 887-8), XX. (I889-9o).

1030. Subsidy Roll of Leigh, Lancashire. I332. Lancasbire and Chesbire Notes, II. I879-8I. I031. Subsidy, Lay, London, I4I I-I 2 (J. C. L. Stahlschmidt). Archaol. Fournal, XLIV. I 887 . 
1032. Subsidy Roll in the possession of Lynn Regis (G. H. Dashwood). Norfolk Archaology, I. 1847 .

1033. Subsidy Roll, Lay, of 1327 , Shropshire (W. G. B.

Fletcher). Shropshire Arch. and Nat. Hist. Soc. Transactions, and series, I., IV., V., VIII., X., XI. ; 3rd series, V., VI., VII. I889-1907. 1034. Subsidies, Lay, 1327 [Somerset]. Somerset Record Soc. 1889.

1035. Subsidy Roll, Lay, of 1327 [Staffordshire] (G. Wrottesley). William Salt Arch. Coll., VII. 1886.

1036. Subsidy Roll of 6 Edward III., 1332-1333 [Staffordshire] (G. Wrottesley). Wm. Salt Arch. Soc. Collections, X. 1890.

1037. Subsidy Roll, Suffolk, in 1327. Suffolk Green Books, No. 9, Vol. II. 1906.

1038. Subsidies, The Three Earliest for the County of Sussex in the years $1296,1327,1332$ (W. Hudson). Sussex Record Soc., X. 1910.

1039. Subsidy, Roll of a, levied I 3 Henry IV., I 4 I I-1 2 [Sussex] (translated by T. H. Noyes). Sussex Arch. Soc. Collections, X. 1858.

1040. Subsidy Roll, The [1327], of Warwickshire. Midland Record Soc., III.-VI. 1899-1902.

1041. Subsidy Rolls, Lay, Worcester, I 280-1603. Worcester Hist. Soc. 1893-1902.

1042. Subsidies, Lay, Yorkshire. Thoresby Misc. 1891 .

1043. Subsidies, Lay, Yorkshire, 1297, $1301-2$ (W. Brown). Yorkshire Arch. Soc. Records Series, XVI., XXI. I 894, I 897.

1044. Tallage, The, of 6 Edward II. and the Bristol Rebellion (E.A. Fuller). Bristol and Gloucester Arch. Soc., XIX. 1895.

1045. Taxation of the tenth and fifteenth in Hampshire in 1334. Collectanea Topog. et Genealogica. 1834 . 


\section{C.-JUdiCIAL PROCEEDINGS.}

As a series the pleadings of the Courts of Law throw considerable light upon such matters of economic interest as manorial tenures and customs, the status of villeins and labourers, the distribution of land, commercial intercourse, and the custom of merchants, the royal revenue and control of trade, etc. In view of their vast bulk, however, and the scanty provision of lists, calendars or texts as yet existing, these main series of records of the Courts of King's Bench, Common Pleas, Exchequer, and Chancery, are perhaps of less importance than the subsidiary documents or the special inquisitions, which can only be distinguished from ministerial proceedings by their judicial character. Many of these inquisitions are incorporated with the pleadings in question, whilst others are separately filed as returns to writs of inquisition. Their relationships have been described in the Formula Book (Pt. 2), where also specimens of the various types are printed. In addition to the pleadings in the King's Courts and the Placita in Cancellaria (which include many cases under the law merchant), the proceedings of the Council and Parliament may be included here, whilst the records of independent jurisdictions such as the Palatinate or Duchy Courts, the Marshalsea and Palace Court, the Forest Courts, the pleas of the Exchequer of the Jews and of the Admiralty Courts, are deserving of close attention. Many records of cases and excerpts from Plea Rolls, Feet of Fines, etc., have been published in the transactions of local societies. The judicial proceedings to which reference is made above will be found described in considerable detail in the official Guide. The bibliography of this division is imposing, though by no means commensurate with the bulk of the surviving records. Details are given by $\mathrm{C}$. Gross, sections $5 \mathrm{I}$ and 52 , and the construction of these records is discussed in the Formula Book (Pt. 2). 
(i) Laws and Ordinances.

1046. Bracton, De Legibus et Consuetudinibus Angliae (Sir Travers Twiss). Rolls Series. $1878-83$.

1047. Britton [on the Laws of England], containing the ancient pleas of the Crown (R. Kelham). 1762.

1048. Chartes des Libertés anglaises [1100-1305] C. Bémont). Paris, 1892 .

1049. Fleta, seu Commentarius Juris Anglicani. 1685. I05O. Fortescue, $S_{I R}$ J. De laudibus Legum Angliae (J. Selden). I6I6.

1051. Gesetze (Die) der Angelsachsen (F. Liebermann). Halle, I 898-1 906.

1052. Gesetze der Angelsachsen (R. Schmid). Leipzig, 1858.

1053. Glanville, Treatise on the Laws and Customs of the Kingdom of England, translated ( $\mathrm{J}$. Beames). 1812.

1054. Horne, Andrew. The Mirror of Justices (F. W. Maitland). Selden Society. 1895.

1055. Law Tracts (Four 13th century), (G. E. Woodbine). I9ro.

1056. Placita Anglo-Normannica(M.M. Bigelow). I 879. 1057. Quadripartitus, ein englisches Rechtsbuch, von III4 (F. Liebermann). Halle a.S, 1892.

1058. Registrum omnium brevium tam originalium quam judicialium. 1687.

See also Selden Society's Publications and No. 486.

(ii) Privy Council and Parliament.

1059. Record Commission. Ancient Laws and Institutes of England (B. Thorpe). 1840.

1060. Parliament Rolls [Rotuli Parliamentorum] 1278-1503. 1767-77.

1061.- - Parliament Rolls, Index to [1278-1 503]. 1832. 1062. - Parliamentary Writs and Writs of Military Summons [Edward I.-Edward II.] F. Palgrave). $\quad 1827-34$. 
1063. Record Commission. Privy Council of England, Proceedings and Ordinances [1386-1452] (Sir Harris Nicolas). $1834-37$.

1064. - Statutes of the Realm [IIOI-I7I3] (A. Luders, T. E. Tomlins, J. Raithby and others). I $810-28$.

1065. Rolls Series. Memoranda de Parliamento: Records of the Parliament at Westminster in I305 (F. W. Maitland). Rolls Series. 1893.

(iii) Pleadings in the Courts.

I066. Bracton's Note Book, etc. (F. W. Maitland). I 887.

1067. Crime and Accident in Norfolk (W. Rye). Archeological Review. I 889.

1068. Crown Pleas for the County of Gloucester, I22 I (F. W. Maitland). I884.

1069. Curia Militaris. De Controversia inter Ricardum le Scrope et Robertum Grosvenor, I 385-90 (N. H. Nicolas). I832.

1070. Fines, Feet of [1182-99]. Pipe Roll Soc. I 894-I900.

107r. Pedes Finium ... for the County of Somerset. Richard I. to Edward I. (E. Green). Somerset Record Soc. I892-98. See also Record Commission.

1072. Forest Pleas, Extracts. In Honor and Forest of Pickering (R. B. Turton). N. Riding Record Soc. Vols. I.-IV. I 894-97.

1073. Itinerant Justices, Somersetshire Pleas from the Rolls of [close of the r 2th century to I256] (Sir C. E. H. Chadwyck Healey). Somerset Record Soc. 1897.

1074. King's Bench Court, Pleas of the [1297] (W. P. W. Phillimore). Index Library. I898. I075. King's Court. Three Rolls of [I I94-95] (F. W. Maitland). Pipe Roll Soc. I891. 
1076. Plea Rolls, Extracts from [Richard I.-Henry VI.] (G. Wrottesley). W. Salt Arch. Soc. $1883-96$.

1077. Record Commission. Chancery Proceedings, Calendars of. Vol. I., pp. i-cxvii., Richard II. -Henry VII. ; Vol. II., pp. i-Ixxvi., Richard II.-Richard III. I 827,1830 .

1078. - Curix Regis Rotuli (Sir F. Palgrave). 1835 . 1079. Documents illustrative of English History in the $13^{\text {th }}$ and $14^{\text {th }}$ centuries ( $\mathrm{H}$. Cole). 1844 .

1080. Exchequer, Antient Kalendars, Vol. I., App. 1836.

1081. - Fine Rolls [Rotuli de Oblatis et Finibus] I 199-1 216 (Sir T. D. Hardy). 1835.

1082. Fines sive pedes finium [II95-1214] (J. Hunter). $1835-44$.

1083. Placitorum Abbreviatio [Richard I.-Edward II.]. $18 \mathrm{II}$.

1084. Quo Warranto, Placita de [Edward I.Edward III.] (W. Illingworth). 1818.

1085. Rotuli Hundredorum temp. Henry III. et Edward I. I812-18.

1086. - Rotuli Selecti (J. Hunter). 1834. 1087. Revenues of the Crown (Woods, Forest, and Land); Reports of the Commissioners. 17 Reports printed in the Journals of the House of Commons, 1787-93. Vols. XLII.-XLVIII. Contains perambulations of the forests temp. Edw. I.

1088. Rolls (Assize) for the County of Northumberland. Three early. (W. Page.) Surtees Soc. 1891 .

1089. Rolls Series. Year Books, 1338, sq. (L. O. Pike.) 1863, etc.

I090. SELDEN SocietY. Admiralty Court, Select Pleas, 1364-1602 (R. G. Marsden). 1892, I897. 
109i. Selden Society. Chancery Cases, Select [1364I47I] (W. P. Baildon). 1896.

1092. Civil Pleas, Select [1 200-I 203] (W. P. Baildon). 1890 .

1093. Coroners' Rolls, Select cases, 1265-1413 (C. Gross). I 896.

1094. Crown Pleas, Select, I200-I 225 (F. W. Maitland). I 888.

1095. - Eyre of Kent, I3I3-I3I4 (ed. by the late F. W. Maitland and others). IgIo.

I096. - Forest Pleas, Select (G. J. Turner). rgor.

1097. - Jews' Exchequer, Select Pleas, Starrs, and other Records from I220-I 284 (J. M. Rigg). 1902.

1098. Year Books, I307-10. 1903-5.

1099. State Trials of the Reign of Edward the First [1289-I 293] (T. F. Tout and H. Johnstone). Royal Hist. Soc. 1906.

\section{D.-MISCELLANEOUS RECORDS.}

Although this heading should properly be given, for the purpose of including many documents which are not of official origin, such as those that have been confiscated by the Crown, or deposited and not reclaimed by suitors, it would be found, in fact, that the greater number of such documents have now been incorporated in cognate official series, and therefore a distinction of this sort is scarcely required in practice. It should be remembered, however, that there are a large number of composite records, such as precedent books, containing specimens of Diplomatic, Ministerial, and Judicial records intermixed, but very few of these "Miscellaneous Books" have been either published in full or calendared.

For lists of these, see the Guide, s.v. "Registers and Books of Remembrance," and "Miscellaneous Books" (Exchequer). 


\section{Div. II.-LOCAL RECORDS AND LITERARY MSS.}

A sharp distinction has usually been made in this country between public and private archives, but there has recently been a tendency (emphasised in the Treasury Report on Local Records, 1902) to regard many of the latter as documents of a semi-public nature. Again, the collections vested in certain trustees and corporations, such as those administering the libraries of the British Museum and the great Universities, may be regarded as practically open to the public, whilst some other corporate bodies, institutions, and learned societics give reasonable facilities of access. The exceptions to this practice are, however, numerous, and include, moreover, the bulk of the private collections which are of the greatest importance to the student of Economic History. Again, some notable collections, containing public documents appropriated by former officials, have been dispersed and portions sold to foreign purchasers.

It has been the practice of bibliographers to classify and describe all the above sources pari passu with the Public Records. The objection to this plan, apart from its unscientific character, is that the student is not assisted thereby to realise either the provenance of the sources or their present location. These are points of much importance for the purpose of enabling the student to trace scattered documents or to make the necessary dispositions for obtaining access to the collections.

The following classification will perhaps be found useful as a key to the general distribution of the sources.

I. Documents in the custody of "public" museums or libraries and learned societies (chicfly antiquarian).

2. Documents in the custody of "private" corporations (ecclesiastical, legal, municipal, trading).

3. Documents in the custody of private individuals. 
In respect of the above collections it may be noticed that class I comprises the so-called "made collections," in distinction to the inherited muniments or cognate MSS. in the possession of class 2, whilst class 3 includes collections of both types. It may also be observed that certain "Local Records" are actually public records under the Act of $183^{1}$; but although many of these collections contain State documents which have been formerly removed from the archives, very few mediæval records have been thus abstracted.

In another aspect these Local Records may be broadly classified for economic purposes as comprising manorial, agrarian, municipal, and statistical documents, besides many which may be recognised as counterparts or subsidiary processes of official records. In view of the great diversity of the contents of local repositories, a precise and scientific classification will be found even more valuable than in the case of the State Archives. This will also serve to explain the relationship between certain types which occur equally in official and private collections. The details of this classification will be found below, and it only remains to add that the "instruments of study," in the shape of lists, indexes and calendars, are noticeably deficient. Exceptions must be made in the case of class I above referred to whilst the remaining classes have during the last generation been rendered more accessible by the enterprise of certain private corporations and individual owners, as well as through the activities of the Historical Manuscripts Commission (cf. Trans. $R$. Hist. Soc., 3rd Ser, IV.). Unfortunately, however, many careful inventories of local records remain unprinted or unpublished, and the bibliographical indications are thus obscure. A key to the Historical MSS. Commission is published in the Seventeenth Report, and the returns printed in the Report on

\footnotetext{
${ }^{2}$ E.g. - Records of the Palatinate of Ely, still preserved in the episcopal registry.
} 
Local Records (Appendix 3, Query 8) will be found invaluable. In respect of published texts, the provision made by various agencies, though considerable, is very unevenly distributed. Some useful references will be found in the bibliographies of Gross, Davenport and Moore. The "select list" printed below has been rigorously curtailed by the exigencies of space.

\section{A.-DIPLOMATIC DOCUMENTS.}

\section{(a) Charters, Letters Patent, and other Royal Instru- ments.}

These are the originals of instruments enrolled in the archives. A still larger number, however, are preserved in cartularies, registers, etc. Like the succeeding class, they are usually carefully listed, and have been extensively printed. For practical purposes however, they cannot be distinguished from the following class, and specimens of each type of instrument will be found below.

Collections of charters printed by private persons are so numerous that only a few specimens can be given here (Nos. I 100, sq.). These have been selected as examples of collections covering either an extensive area or a long period, or affecting important institutions. Various charters of much economic interest will be found in the Publications of the Record Commission and the Rolls Series. Dugdale's Monasticon contains many important diplomata, and many charters both of towns and of religious houses have been printed by the Historical Manuscripts Commission. Examples of English societies publishing diplomata of economic interest are included :1100. Anglo-Saxon Manuscripts, Facsimiles of, Ordnance Survey. I878-1884.

I101. Bernewelle, Liber Memorandorum ecclesie de (J. W. Clark). 1907. 
1102. Bristol, Charters of (S. Seyer). 1812.

I 103. British Museum, Facsimiles of Ancient Charters in (E. A. Bond). $1873-8$.

I 104. Cartularium Saxonicum (W. de Grey Birch). I 885-99.

1105. Calverley Charters (W. P. Baildon and S. Margerison). Thoresby Society, Vol. VI. Leeds, 1902.

I 106. Cinque Port Charters (J. H. Round, Feudal England, p. 563). 1909.

1 107. Cinque Ports, Indexes of the Great White Book and the Black Book of the. 1905.

1 108. Clitheroe, Ancient Charters of (J.Harland). 1851. I 109. Cluniacense Monasticon Anglicanum : or Charters and Records ... of the Ancient Abbey of Cluni (1077-1 534). G. F. Duckett. I888.

Iro. Codex Diplomaticus aevi Saxonici (J. M. Kemble). English Hist. Soc. 1839-48.

II I I. Colchester, Charters and Letters Patent granted to. 1903 .

I 1 1 2. Colchester, Red Paper Book of (W. G. Benham). I902.

III3. Colchester, Red Parchment Book of (W. G. Benham). 1907.

III4. Crawford Collection of early charters and documents now in the Bodleian Library (739-1 1 50). Anecdota Oxon. VII., (A. S. Napier and W. H. Stevenson.) Oxford, 1895 .

II 5. Diplomatarium Anglicum aevi Saxonici (B. Thorpe). 1865.

II 16. Dover, History of the Town and Port of ... with a short account of the Cinque Ports (J. Lyons). 1813.

I 1 7. Dugdale, W. Monasticon Anglicanum. New ed., with many additions by J. Caley, $\mathrm{H}$. Ellis, etc. 1846 .

II18. Exeter, Monasticon Diocesis Exoniensis (G. Oliver). $\quad 1846$. 
1119. Flaxley, Cartulary of the Cistercian Abbey (A. W. Crawley-Boevey). 1887.

1120. Fraser, Simon. Reports of the Proceedings before Select Committees of the House of Commons. (Contains selections from Charters of Okehampton, Pontefract, etc.) 1791-3.

1121. Furness Abbey, The Coucher Book of (J. C. Atkinson). Chetham Society. I885, etc.

1122. Gloucester, Calendar of the Records of the Corporation of (W. H. Stevenson). 1893.

1123. Hereford, Ancient Customs of the City of (R. Johnson). 1882.

1124. Ilchester Almshouses Deeds, I200-1625 (W. Buckler). 1866.

1125. Kingston-on-Hull, Charters and Letters Patent (translated by J. R. Boyle). 1905.

1126. Land Charters and other Saxonic Documents, a Handbook to the (J. Earle). Oxford, 1888 .

1127. Leach, A. F. Educational Charters and Documents, 598-1909. I911.

1128. Leicester, Records of the Borough of (M. Bateson). I 899-1905.

11 29. Loders, (Dorset) Cartulaire de (L. Guilloreau). Evreux, 1908.

1130. London, Calendar of Letter Books of the City of (R. R. Sharpe). 1899, etc.

1131. Northampton, Records of the Borough of (C. A. Markham). 1898, etc.

I 132. Norwich, Records of the City of (H. Hudson and J. C. Tingey). 1906, etc.

1133. Nottingham, Records of the Borough of, I1551625 (W. H. Stevenson). I 882-9.

1134. Nottingham, Royal Charters granted to the burgesses of (W. H. Stevenson). I 890.

1135. The Percy Chartulary (M. T. Martin). Surtees Soc. Durham, 1909.

1136. Reading Records (J. M. Guildey). 1892-6. 
1137. Ramsey, Chartularium Monasterii de Rameseia. (W. H. Hart and P. A. Lyons.) Rolls Series. I884.

II38. Romsey Abbey, Records of (H. G. D. Liveing). 1906.

I I39. Wells, Calendar of the Manuscripts of the Dean and Chapter of: Vol. I. Liber Albus. Hist. MSS. Commission. 1907.

I140. Winchcomb, Landboc sive Registrum Monasterii Beate Marie Virginis, etc., de Winchelcumba. I892-I903.

1141. Winchester Cathedral Records. (G. W. Kitchin). Hants Record Society. I 886.

I142. York, Extracts from the Municipal Records of Robert Davies). 1843.

1143. Yorkshire Deeds (William Brown). rork. Archaol. Soc. Record Series. XXXIX. I909.

(b) Deeds, Wills, and other Private Instruments.

These documents are very numerous in private collections, and, like the preceding class, they are widely distributed. But since their value was not as great as that of the Royal Charters, they have not been entered as systematically as the latter. They should be carefully compared with the series in official custody (Nos. 852 sq.), and, like the preceding division, they are extensively represented in the Reports of the Historical Manuscripts Commission. Special mention may be made here of the two following classes of documents :-

Episcopal Registers.-The contents of these entry books are of great economic interest, as they include notices of markets, bridges, tenures, tithes, common rights, usury, etc. In some cases the financial transactions of the bishop with foreign merchants are recorded. As a source of information these Registers have been hitherto strangely neglected, but great progress has been made with their publication during 
the last few years. Certain notable registers had already been printed, and now the work begun by local enterprise is being carried on in a systematic manner by the Canterbury and York Society (Carlisle, Hereford, Lincoln, London). The Local Societies above referred to have been mentioned elsewhere. They include the Somerset Record Society (Bath and Wells), the Hampshire Record Society (Winchester), the Worcestershire Historical Society (Worcester), the Surtees Society (York, Durham), the Sussex Record Society (Chichester), besides a few publications in the Rolls Serics (Durham, York, and Carlisle), or by private enterprise.

1144. Lincoln, Liber Antiquus de ordinationibus Vicariarum tempore Hugonis Wells, I 209-35 (A. Gibbons). Lincoln, I 888.

Wills.-A considerable number of Anglo-Saxon Wills will be found in Kemble and Thorpe, but few wills have survived between the end of the IIth and the early part of the I 4 th century. Most of the latter have been printed, e.g., by the Camden Society (Bury St. Edmunds), Surtees Society (Durham, ed. J. Raine; North Country Wills, ed. J. W. Clay; York, ed. Raine and Richmond), Somerset Record Society (ed. F. W. Weaver), Lancs. and Cheshire Historical Society (ed. W. F. Irvine), the Cumberland and Westmoreland Antiquarian, etc. Society (ed. R. S. Ferguson), the Early English Text Society (ed. F. J. Furnivall), the Kent Archæological Society (ed. L. L. Duncan and A. Hussey), and the London Corporation (ed. R. R. Sharpe). Besides these, several volumes have been published by private enterprise (Nos. I 145-7).

1145. Collection of the Wills of the Kings and Queens of England, Princes and Princesses of Wales, etc., from William I. to Henry VII. (J. Nichols). 1780. 
II46. Early Lincoln Wills (abstracted from the Episcopal Registers), I 280-I 547 (A. Gibbons). Lincoln, I 888.

I 147. Testamenta Vetusta. From the reign of Henry II. (N. H. Nicolas). I826.

(c) Letters. For collections of letters, both official and unofficial. See Division I, A (I) (C) and Nos. 899 sq.

\section{B. MINISTERIAL PROCEEDINGS.}

This class contains Manorial Surveys, Inventories, Accounts, Extents, Rentals and Custumals cognate to the official series. Some of these are also entered in registers or precedent books. With these are included several surveys analogous to Domesday Book.

Miss Davenport's bibliography, supplemented by that of Miss Moore (No. 138), is the best authority for this group, but many references will be found in Prof. Gross's section on "Local Records" and "Town Records," and the publications of the Selden Society, together with the Reports of the Historical Manuscripts Commission, and the invaluable collection of MM. Mély and Bishop (No. 136). A separate list of Churchwardens' Accounts is appended.

1 148. Abingdon Abbey, Accounts of the obedientiars of. Camden Soc. 1892.

I 49. Battle Abbey, Custumals of (S. R. ScargillBird). Camden Soc. 1887.

I I50. Cirencester, Tenures of land by the customary tenants in (E. A. Fuller). Bristol and Glouc. Arch. Trans., II., 285.

II 5 I. Cockersand Abbey, Chartulary of (W. Farrer). Vol. III., 3. Chetham Soc. New Series LXIV. I909.

I152. Coldingham, Correspondence, Inventories, Account Rolls, etc., of. Surtees Soc. I84I. 
I153. Crondal, Collection of Records and Documents relating to the hundred and manor of. Part $\mathrm{I}$. (F. J. Baigent). Hampshire Record Soc. 1890.

154. Cunningham, W. Growth of English Industry and Commerce. Vol. I., app. (Extenta Manerii de Borle, etc.). 1905.

1155. DE LACY, HENRY, Earl of Lincoln, Accounts of Yorkshire Estates, I296. Yorkshire Arch. Soc. Fournal, VIII., XIII. 1890-95.

I156. De Lacy (Henry). Two Compoti of the Lancashire and Yorkshire manors of (P. A. Lyons). Chetham Soc. I884.

1157. Domesday of St. Paul's (W. H. Hale). Camden Soc. 1858 .

I158. Dugdale, W. Monasticon Anglicanum. I81730.

I159. Durham, Extracts from Account Rolls of the Abbey of (1278-1580). I898-1901.

I160. Durham, Feodarium Prioratus Dunelmensis. (Wm. Greenwell). Surtees Soc. Durham, 1872 .

116I. Glastonbury Abbey, Inquisition of Henry de Sully, II89. Roxburghe Club. 1882.

I162. Glastoniæ, Rentalia et Custumaria Monasterii beatæ Marix. Somerset Record Soc. 1891.

in63. Hartshorne, C. H. Feudal and Military Antiquities of Northumberland. App. Royal Arch. Inst. of Great Britain and Ireland. Memoirs, I 852.

I 164. Hatficld's Survey, A Record of the Possessions of the Sce of Durham (Wm. Greenwell). Surtees Soc. Durham, 1857.

1165. Hexham, Priory of (James Raine). Surtees Soc. Durham, i $864-5$.

1166. Ingoldmells, Some Accounts of the Manor of [1295-1485] (W. O. Massingberd). Lincolnshire Notes and Queries, VII. 1904. 
I 67. Kettering, the Compotus of the Manor of, for I 292 (C. Wise). 1899.

I 68. Kirkstall Abbey, A Rent Roll of, I459 (J. Stansfield). Thoresby Soc., II. I89I.

I 69. Knights Hospitallers in England (L. B. Larking). Camden Soc. I 857.

I I 70. [Three] Lancashire Documents of the I $4^{\text {th }}$ and I $5^{\text {th }}$ centuries (J. Harland). Chetham Soc. I 868 .

I 7 I. Liber Niger Monasterii S. Petri de Burgo. Camden Soc. I849.

I 172. Mainecestre (J. Harland). Chetham Soc. I86I62.

I 173. Malmesbury, Rent Roll of the Abbey of, I2 Edward II. (J. Y. Akermann). Archaologia, XXXVII.

I 174. Manydown, The Manor of (W. G. Kitchin). Hampshire Rec. Soc. I895.

I 175. Oxford, The Oldest Account Book of the University of (S. Gibson). English Historical Review, XXIV. 1910.

I 76. Ramsey Abbey, Economic Conditions of $(\mathrm{N}$. Neilson). Appendix. 1898.

I177. Rogers, J. E. T. History of Agriculture and Prices in England. I866-1902. Vols. II. and III. [Accounts, etc.]

I 78. Rolls Series. Abingdon, Chronicon Monasterii de (J. Stevenson). Vol. II. I 858 .

I 79. -Gloucestriæ, Historia et Cartularium Monasterii S. Petri (W. H. Hart). R.S., Vol. III. 1867 .

I 180. - Rameseia, Cartularium Monasterii de (W. H. Hart and P. A. Lyons). I884-93.

I 181 . Rothley, Customary of the manor and soke of (G. T. Clark). Archeologia. I882.

I 82. Stratford, veteri, extenta manerii de, facta anno quinto decimo pontificatus domini Walteri de Cantilupe [1252]. I840. 
1183. Three Manorial Extents of the 1 $3^{\text {th }}$ century (W. Hudson). Norfolk Archacology, XIV. IgoI. 1184. Trevelyan Papers (prior to 1558). Camden Soc. 1857.

1185. Trigg Minor, Parochial and Family History of (Sir J. Maclean). I 873-79.

1186. Warrington in 1465 , as described in a contemporary Rent Roll (W. Beaumont). Chetham Soc. 1849.

1187. Wedcwood, J. Inquests on the Staffordshire Estates of the Audleys. Wm. Salt Arch. Soc. XI. 1908.

I 188 . Winchester, Pipe Roll of the Exchequer of the See of, for the fourth year of the Episcopate of Peter des Roches [1207]. (London School of Economics. 1903.

I189. Worcester, Early Compotus Rolls of the Priory of (J. M. Wilson and G. Gordon). Worcestershire Hist. Soc. 1908.

I 190. Worcester, Compotus Rolls of the Priory of, of the $14^{\text {th }}$ and $15^{\text {th }}$ centuries (S. G. Hamilton). Worcestersbire Soc. Hist. I9Io.

II9I. Worcester Priory. Registrum ... prioratus beatae Mariae Wigorniensis (W. H. Halc). Camden Soc. 1865 .

Churchwardens' Accounts.-For a few more titles not included in this list, see the valuable list compiled by Miss Philipps (No. 139). A considerable proportion of the printed texts have been issued by learned societies. These include the Somersetshire Archæological, etc., Society (C. B. Pearson); the Somerset Record Society (Bishop Hobhouse), the Bristol and Gloucester Archæological Socicty (Sir J Maclean), the Sussex Archrological Collection (W. B. Otter), Transactions of the Devon Association (R. Dymond), the Wilts Record Society (H. J. F. Swayne); the 
Berks, Bucks, etc., Archæological Journal (F. G. Lee); Transactions of the Shropshire Archæological Society (L. Jones); Archæologia Cantiana (J. M. Cowper); Ibid. (H. B. Mackeson and W. A. S. Robertson); Proceedings of the Society of Antiquaries of London (R. S. Mylne); Collectanea Topographica et Genealogica (Vol. III, 1836); Early English Text Society (H. Littlehales); Camden Society (Miscellany, Vol. VII); British Magazine and Monthly Register XXXI -XXXVI.

The following texts have been published by private enterprise :-

I192. Ashburton: The Parish of, in the I5th and I6th centuries (J. G. Butcher). 1870.

Extracts from Churchwardens' Accounts, 1479-1580.

I193. Bishop's Stortford : St. Michael. Records of St. Michael's Parish Church (J. L. Glasscock). I 882 .

Churchwardens' Accounts from 143 I.

I I94. Derby : All Saints. Chronicles of the collegiate Church of (J. C. Cox and W. H. St. John Hope). I 88I.

I195. London : St. Michael, Cornhill. The Accounts of the Churchwardens, 1456-1608 (W. H. Overhall). I871.

I 196. Tavistock: Calendar of Parish Records (R. N. Worth). Plymouth, I 887.

I 197. Illustrations of the Manners and Expenses of Antient Times in England (J. Nichols). 1797.

\section{C.-JUDICIAL PROCEEDINGS.}

Although this section only faintly corresponds with that comprising the Records of the King's Courts, many transcripts or reports of legal proceedings and original treatises are preserved in private collections. These also include many original or unique records and 
versions of early laws and ordinances, besides a large and important series of local municipal ordinances. The great bulk, however, of the Court Rolls in private custody relate to the routine procedure of the manorial courts. The bibliography of these muniments is practically in the same state as that of the former section, except that further information may be obtained from F. Licbermann's Gesetze (No. 105I), C. Gross's Municipal Bibliography (No. I2I), and the works of Pollock, Maitland and Vinogradoff.

1198. Alrewas (Staffs), Court Rolls [1 259-73] (W. N. Landor). Wm. Salt Arch. Soc., X. 1907, 1910.

1199. Baslow (Derbyshire), The Court Rolls of [1319-153I] (C. Kerry). Derbyshire Arch. and Nat. Hist. Soc. Trans., XXII., XXIII. I 900-OI.

1200. Conveyancer (A) in the Thirteenth Century, John of Oxford (F. W. Maitland). Law Quarterly Review, VII., 63-69. I891.

1201. Coventry Leet Book, 1420-1555 (M. D. Harris). Early English Text Soc. 1907-9.

1202. Clitheroe, Court Rolls of the Honor of (W. Farrer). 1897.

1203. Doncaster, Records of. Court Rolls, 1454 et seq. W. J. Hardy). Doncaster [1899-I903].

1204. Durham, Depositions and other Ecclesiastical Proceedings from the Courts of, I 3 II to Elizabeth (J. Raine). Surtees Soc. Durham, 1845 .

1205. - Halmota Prioratus Dunclmensis, I296I384 (W. H. D. Longstaffe and J. Booth). Surtees Society. Durham, I 889.

1206. Great Cressingham, Co. Norfolk, Five Court Rolls of, I 328-1 584 (H. W. Chandler). 1885. 1207. Hales, Court Rolls of the Manor of, I 272-1 307 (J. Amphlett and S. G. Hamilton). Worcestershire Hist. Soc. 1910. 


\section{I24 A SELECT BIBLIOGRAPHY OF}

I 208. Holmesfield, Co. Derby, The Court Rolls of the Manor of, I480-165I (C. Kerry). Derbyshire Arch. and Nat. Hist. Soc., XX. 1898.

I209. Ilkley, Manor Court Roll extracts, I357-I692. See Ilkley Ancient and Modern, ch. viii. (R. Collyer and J. H. Turner.) I885.

I210. Ingoldmells, Court Rolls of the Manor of, I 29I-I 569 (W. O. Massingberd). I902.

I2I I. Lancaster. Some Court Rolls of the Lordships, Wapentakes and Demesne Manors of Thomas, Earl of Lancaster, in the County of Lancaster, for the 17 th and 18 th years of Edward II., A.D. 1323-4. (W. Farrer.) Lancasbire and Chesbire Record Soc., XLI. I90I.

I212. Leicester, Records of the Borough of (M. Bateson). I899-1905.

I2I3. Littleport, Court Baron (The), together with Select Pleas from the Bishop of Ely's Court of (F. W. Maitland and W. P. Baildon). Selden Society. 1894 .

1214. Manorial and other Seignorial Courts, Select Pleas (F. W. Maitland). Selden Society, 1889.

121 5. Norwich, Leet Jurisdiction in the City of, during the I $3^{\text {th }}$ and I $4^{\text {th }}$ centuries (W. Hudson). Selden Society. 1892.

1216. Peterborough, Court Leet, The English and Latin Versions of a (M. Bateson). English Historical Review. 1904.

1217. [Seven] Somerton Court Rolls, 1482-I573 (A. Ballard). Oxfordsbire Arch. Soc. Trans., I 906.

I218. Standon Court Rolls, I338-I773, abstracts translated. See History of Standon Parish, Manor and Church. (E. Salt.) I 888.

I219. Thorner, Fourteenth Century Court Rolls of the Manor of. (W. T. Lancaster.) Thoresby Soc., XV., Misc., V., Pt. 2. 1906.

I220. Tooting Beck Manor, Court Rolls of, I 246-I422 (G. L. Gomme). London County Council. I909. 
1221. Wakefield, Court Rolls of the Manor of, 12741309 (W. P. Baildon). Yorksbire Arch. Soc. Record Serics, XXIX., XXXVI. $1901,1906$.

1222. Wimbledon, Extracts from the Court Rolls of the Manor of [1461, etc.]. 1866.

1223. Wreyland Documents (C. Torr). 1910.

Court Rolls, 1437, etc.

\section{D.-MISCELLANEOUS MUNIMENTS AND LITERARY MSS.}

Many texts and treatises and other compilations of economic interest are to be found in private collections, side by side with documents described in the three preceding sections. Together with these, mention must be made of a large class of literary works, such as Histories, Chronicles, Annals, Devotional and Theological works, and Poetry. These manuscripts, which chiefly occur in public collections, have been fully described and for the most part published. For details reference should be made to C. Gross (No. 84), to the bibliographies appended to the Cambridge History of English Litcrature, Vols. I. and II., and to the works of Hardy (No. 255), Potthast (No. 80), and Chevalier (No. 78).

The value of Histories, Chronicles and Annals is obvious as supplementing the information to be obtained from the Records: and while they supply to some extent the point-of-view of eyewitnesses of the economic events which they describe, yet the mental attitude of the Middle Ages is still more intimately displayed in the almost casual and incidental references contained in the literature of the period. Few things are more eloquently descriptive of everyday life in the II th century than Aelfric's Colloquy - a brief readingbook for the beginner in Latin; and the Ancren Riwle, while giving a detailed picture of the life of ancresses in the 13 th century and of their relations with the community around them, gives also, in simile and illustration, many sidelights upon contemporary social 
life. Much information as to social conditions can be gleaned from theological works, such as Handlyng Synne, Dives et Pauper, Myrc's Instructions, and the works of Wyclif and his followers: while the Philobiblon gives, together with information as to the book trade, details of the life of the clergy and of the clerks at the university. Political poems, Piers the Plowman, and the works of Chaucer and Gower contain a mine of wealth. Contemporary treatises of popular science have a less direct value but are still of service, more particularly the great work of Bartholomaeus Anglicus. Besides affording sidelights upon society, theological works have the peculiar value of setting forth the teaching of the Church in regard to economic matters : the most elaborate work of this kind in English is Dives et Pauper; but any such manual (as, for example, the Ayenbite of Inwyt-a poor translation of the Somme le Roi), treating of the decalogue or the seven deadly sins, will not fail to afford at least a statement of the canonist doctrine of usury.

1224. Analecta Anglo-Saxonica (B. Thorpe). 1868. Contains, pp. I 8 seq., Aelfric's Colloquy, which is also printed in Wülcker-Wright's Vocabularies (No. 4II).

1225. Ancren Riwle (J. Morton). Camden Soc. 1853. 1226. Bartholomaeus Anglicus. De Proprietatibus Rerum. Extracts (transld.) ed. R. Steele under title "Mediæval Lore from Bartholomew Anglicus," 1905. (Many times printed in $15^{\text {th }}$ and 16 th centuries in Latin and translations, including English.)

I227. Chaucer, Geoffrey. Works (W. W. Skeat). Oxford, I 894-1900. Vol. VII. Chaucerian and other Pieces not by Chaucer.

1228. Débat des Hérauts d'Armes de France et d'Angleterre (P. Meyer). Societé des Anciens Textes Français. Paris, 1877. 
1229. Dives et Pauper. 1536 (Berthelet: previous editions by Pynson and Wynkyn de Worde). Composed in carly years of $15^{\text {th }}$ century : see Notes and Queries, I I S. IV., 32 I.

1230. Map, Walter. Latin Pocms attributed to (T. Wright). Camden Soc., I841.

123I. MYrc, John. Instructions for Parish Priests (E. Peacock). E.E.T.S. 1902.

1232. Picrce the Ploughman's Crede (W. W. Skeat). Oxford, 1906.

1233. Piers the Plowman (W. W. Skeat). Oxford, 1886. (Contains also "Richard the Redeless," a poem on the deposition of Richard II.)

1234. Richard de Bury. Philobiblon (E. C. Thomas). 1888.

1235. Robert of Brunne. Handlyng Synne (F. J. Furnivall). E.E.T.S., I90I-3. (Contains also the French original, William of Wadington's Manuel des Pechiez.)

1236. Rolls Series. Leechdoms, Wortcunning, and Starcraft of Early England (O. Cockayne). I 864-66.

1237. - Anglo-Latin Satirical Poets and Epigrammatists of the Twelfth Century (T. Wright). 1872 .

1238. Political Poems and Songs ... Edward III. to Richard III. (T. Wright). 1859-61. (The Libell of Englishe Policye contained herein, re-edited separately by W. A. B. Hertzberg. Leipzig, 1878.)

1239. SNEYD, C. A. A Relation of the Island of England ... about 1500. Camden Soc., 1847 .

1240. Wright, T. Political Songs. ... John to Edward II. Camden Soc., 1839: reprinted, with omissions, Edinburgh, I884.

124I. - Popular Treatises on Science written during the Middle Ages. Hist. Soc. of Science, I841. 


\section{I28 A SELECT BIBLIOGRAPHY OF}

1242. Wyclif, John. English Works. Select English Works (T. Arnold). Oxford, I869-7I. English Works - . hitherto unprinted (F. D. Matthew). E.E.T.S., I880.

1243. Latin Works : in course of publication by Wyclif Soc., I882, etc. 


\section{SECTION II. \\ England's Sister Kingdoms.}

The classification adopted in the following succinct description of some of the sources of Scottish, Irish, and Welsh history that may be useful for the study of English Medireval Economic History is as follows : In the first place the Sources in the case of each of the above countries are grouped as "Official" or "Unofficial" respectively. Secondly, each of these classes is divided into the following sections according to the nature of the documents-(a) Diplomatic Documents, (b) Ministerial Proceedings, (c) Judicial Proceedings, (d) Miscellaneous.

\section{1.- SCOTLAND.}

The romantic vicissitudes of the earliest Scottish records, from the reign of Edward I. to the Protectorate, are described in several learned treatises and are well summarised in Livingstone's Guide (No. 163). The reports of the Record Commissioners (1800-1837) and of the English Deputy-Keeper give further information, but it is clear that a great loss of early records has taken place. Those that have survived have been deposited in the Register House, Edinburgh, since 1784 . Since 1879 they have been definitely placed in the custody of the Deputy-Clerk Register with a Deputy-Keeper and a Curator of the Historical Department as distinguished from the General Record Office. The following series are those which appear to be the most valuable for medixval Economic History. It is noticeable, however, that little use has hitherto been made of them in this connection.

The official classification of the Scottish Records, which is practically a proprietary one, is as follows :- 
Class 1.-Crown, Parliament, Revenue, and Administration.

None of the records relating to the Regalia, etc., are of early date, though perpetuating ancient traditions. The same remark applies to the records of the Parliament and Council (the Acta Dominorum Concilii being classified with the Judicial records), and the State papers are, of course, later than the mediæval period. However, amongst the contents of a large class of fiscal and administrative records there are series of Crown Rentals (from 1476), Exchequer Rolls (from I264), Treasurers' Accounts (from 1473).

\section{Class 2.- Fudicial Records.}

No mediæval records have survived with the exception of the Acts of the Council above referred to. A large number of records for regalities and seignorial courts has been brought in, but these are also of postmediæval date.

\section{Class 3.-Titles to Land, Dignities and Offices.}

One section at least of these important records represents the activities of the mediæval Scottish Chancery, namely the "Registers of the Great Seal." The existing Registers (these Chancery enrolments being in book form as in the continental Chanceries) date from I306. No mediæval registers of the smaller seals survive, and the statutory enrolments of titles are of considerably later date.

\section{Class 4.-Ecclesiastical and Miscellaneous Records.}

The only mediæval documents preserved under this heading are a few miscellaneous accounts, wills, etc., deposited by corporations and private owners for safe custody.

Considerable progress has been made with the publication of the Scottish Records, and the series above-mentioned have been either printed in extenso 
or fully calendared in the official series of Record Publications issued by the Register House, Edinburgh. The "Scottish Documents" still preserved in the Public Record Office, London, are briefly described in Scargill-Bird's Guide, but they have been calendared in the Rolls Series (No. 1249), together with extracts from the regular series of English records which refer to Scottish affairs. The Scottish Rolls were printed by the Record Commission (No. 1247). The texts of records relating to the claim of English supremacy, which have been published in the Foedera and other series of documents, are of little economic interest.

With regard to the unofficial manuscript sources, reference may be made to the brief account of the Inventories of Scottish Local Records and MSS. given above (p. 18). Owing to the great destruction of mediæval records in Scotland it is probable that very few materials remain to be discovered in this direction, but owing to the comparative inaccessibility of these documents the surmise cannot be verified here. It may be observed, however, that there is this important distinction between the English and the Scottish national records; that the latter intentionally include certain local records by virtue of Acts of Parliament. In fact, Scotland, following here again the continental practice, had established in the $14^{\text {th }}$ century a General Register of titles to land. In the reign of James VI. (I6I7) the district Register of Sasines and Hornings and the Notarial Registers were ordered to be transmitted to the Central Registry. Other local records have been transmitted by later Acts of Parliament; but in spite of the advantages of this system (which was advocated for English landtitles in 1619) comparatively few mediæval documents have been transmitted to the Register House at Edinburgh, and many early local records must either have been destroyed or are still outstanding. 


\section{A.-Diplomatic Documents.}

(a) Official.

1244. Calendars of the ancient Charters and of the Welsh and Scottish Rolls in the Tower of London (J. Ayloffe). 1774.

1245. Early Scottish Charters, prior to II53 (A. C. Lawrie). Glasgow, 1905.

1246. Record Commission. Documents and Records illustrating the History of Scotland, and Transactions between Scotland and England (F. Palgrave). I837.

I247. - Rotuli Scotiæ, I9 Edward I.-Henry VIII. (D. Macpherson, J. Caley, etc.) I814-1818.

I248. Scotland in 1298 (H. Gough). Paisley, I 888.

1249. Scottish Record Publications. Calendar of Documents relating to Scotland (J. Bain). Edinburgh. I88I-88.

1250. Documents illustrative of the History of Scotland, I286-1 306 (J. Stevenson). Edinburgh, I870.

1251. - Registrum Magni Sigilli Regum Scotorum. Vol. I. (T. Thomson). I8I4. Vol. II. (J. B. Paul), Edinburgh, I882.

1252. Vetera Monumenta Hibernorum et Scotorum historiam illustrantia, I 2 r6-1 547 (A. Theiner). Rome, I864.

(b) Unofficial.

1253. Bannatyne Club. Aberbrothoc, Liber $\leqq$. Thome de, registrum vetus, II 78-1329 (C. Innes and P. Chalmers). Edinburgh, 1848. 1254. -Dryburgh, Liber S. Marie de: registrum cartarum (W. Fraser). Edinburgh, 1847.

1255. - Dunfermelyn, Registrum de : Liber cartarum abbatie de Dunfermelyn (C. Innes). Edinburgh, 1842. 
1256. Bannatyne Club and Maitland Club. Glasguensis Episcopatus Registrum, c. 1200-1581 (C. Innes). Edinburgh, 1843 .

1257. Kelso Abbey, Liber S. Marie de Calchou : Registrum cartarum Abbacie de Kelso, II 3-1567 (C. Innes). Edinburgh, 1846.

1258. Melros, Liber Sancte Marie de : Muniments of the Abbacy of Melros (C. Innes). Edinburgh, 1837 .

1259. Morton, Registrum Honoris de : Ancient charters of the Earldom of Morton (T. Thomson). Edinburgh, 1853 .

1260. Neubotle, Registrum S. Marie de : Chartarium vetus, II40-1528 (C. Innes). Edinburgh, 1849 .

1261. - St. Andrew's Priory. Liber cartarum Prioratus S. Andree in Scotia (T. Thomson). Edinburgh, 1841 .

1262. Cupar-Angus, Rental Book of the Cistercian Abbey of (C. Rogers). Grampian Club. 1879-80. (Duplicate published by British Topog. Soc. 1880.)

1263. Irvine, Muniments of the Royal Burgh of. Ayrshire and Galloway Archaol. Assoc. Edinburgh, 1890, etc.

1264. Laing Charters, Calendar of the, 854-1837. (J. Anderson). Edinburgh, I 899.

1265. Lanark, Extracts from Records of (R. Renwick). Glasgow, 1893 .

I266. Maitland Club. Aberdonensis Episcopatus Registrum (C. Innes). Edinburgh, 1845.

Glasguensis Episcopatus Registrum. See No. 1256.

1267. Paisley, Charters and Documents relating to the Burgh of, I163-1665 (W. M. Metcalfe). Paisley, 1902.

1268. Renfrew, Archæological and Historical Collections relating to the County of. Paisley, 1885, etc. 
1269. Scottish Burgh Records Society. Edinburgh, Charters and other Documents relating to the city of, II43-r540 (J. D. Marwick). Edinburgh, r871.

I 270. - Glasgow, Charters and Documents relating to the city of (J. D. Marwick). Glasgow, I 894-1906.

1271. - Peebles, Charters and Documents and Extracts from Records of Burgh of, II65-1710 (W. Chambers). Edinburgh, 1872.

1272. - Setts or Constitutions of the Royal Burghs of Scotland. (Miscellany, ed. by J. D. Marwick). Edinburgh, I88I.

1273. ScotTish History Society. Inchaffray, Charters, Bulls, and other Documents relating to the Abbey of (W. A. Lindsay, etc.). Edinburgh, I908.

1274. Lindores, Chartulary of the Abbey of ( $\mathrm{J}$. Dowden). Edinburgh, 1903.

1 275. Stirling, Charters and other Documents relating to the Royal Burgh of, I $124-1705$ (R. Renwick), Glasgow, I 884 .

1276. The Scottish King's household (I4 c.) (M. Bateson). Miscellany, Vol. II.

\section{B.-Ministerial Proceedings.}

1277. Coldingham Priory, The correspondence, inventories, account rolls, and law proceedings of (J. Raine). Surtees Society. Durham, I84I.

1278. Scottish Record Publications. Accounts of the Lord High Treasurer of Scotland, Vol. I. (T. Dickson). Edinburgh, I877.

1279. Exchequer Rolls. Rotuli Scaccarii Regum Scotorum (J. Stuart and G. Burnett). Edinburgh, 1878 , etc.

1280. Scotland in 1298: Documents relating to the campaign of Edward I. in that year $(\mathrm{H}$. Gough). Paisley, I888. 


\section{C.-Judicial Proceedings.}

1281. Bannatyne Club. Concilia Scotix: Ecclesia Scoticanx Statuta, 1225-1559 (J. Robertson). Edinburgh, 1866. (English Translation by D. Patrick published in 1907.)

1282. Record Commission. Acts of the Lords Auditors of Causes and Complaints (Acta Dominorum Auditorum), 1466-1494 (T. Thomson). 1839 .

1283. Acts of the Parliament of Scotland ( $T$. Thomson and C. Innes). 1814-75. (New edition of Vol. I. in 1844.)

1284. Acts of the Lords of the Council in Civil Causes (Acta Dominorum Concilii) (T. Thomson). 1478-1495. I 839.

1285. Records of the Conventions of the Royal Burghs of Scotland (J. D. Marwick). Edinburgh, $1870-90$.

1286. Scottish Burgu Records Society. Ancient Laws and Customs of the Burghs of Scotland, II 24-1424 (C. Innes). Edinburgh, I 868.

1287. - Edinburgh, Extracts from the Records of the Burgh of (J. D. Marwick). Edinburgh, I 869-82.

1288. Stirling, Extracts from the Records of the Royal Burgh of (R. Renwick), Glasgow, 1887.

1289. Spalding Club. Aberdeen, Extracts from the Council Register of the Burgh of, I398-1570 (J. Stuart). Aberdeen, I 844-48.

\section{D.-Miscellaneous Records.}

1290. Maitland Club. Illustrations of Scottish History from the 12th to the 16th century (J. Stevenson). Glasgow, 1834 . 
1291. Scottish Record Publications. Ledger of Andrew Halyburton, Conservator of the Privileges of the Scotch Nation in the Netherlands, 1492-1503 (C. Innes). Edinburgh, I 867.

I 292. Scotland before 1700 , from Contemporary Documents (P. Hume Brown). Edinburgh, r893.

\section{II.-IRELAND.}

Reports on the Irish records were produced by a separate Record Commission (1810-29), but they remained in the custody of the several Courts, etc., till I 867, when a Public Record Office (Ireland) Act was passed, and a Public Record Office was established at Dublin. The fourth section of the above Act vested in the Master of the Rolls all records of extinct jurisdictions, and under this section the records of various regalities and ecclesiastical courts have been brought in, though, unfortunately, the transfers were very incomplete for mediæval records. Some texts and descriptions of these records will be found in the Reports of the Deputy-Keeper of the Records in Ireland since 1869, and in Gilbert's Facsimiles. Much still remains to be learnt as to the nature of the existing Records at Dublin; but the following series will be found of special value for mediæval economic history: ${ }^{1}$

\section{Rolls of Judicial Proceedings.}

I. Justiciary Rolls-

(a) Civil. I295-1394 (continued as Coram Rege Rolls, I 395-I622-3).

(b) Criminal (Placita de Corona and Gaol Delivery Rolls.) I297-I 395.

(c) Recognisances and Bails. 26 Henry VI.44 Elizabeth.

1 Kindly communicated by Mr. Herbert Wood, Assistant-Keeper of the Public Records (Dublin), who is preparing a "Hand-book" to the Irish Public Records. 
2. Rolls of Justices Itinerant. 1252-1306, 1382-1412.

3. Rolls of Justices de Banco (Common Bench Rolls). 1277-1620.

\section{Chancery Rolls.}

1. Patent Rolls [Henry II.] to present day.

2. Close Rolls,

3. Statute Rolls, 9 Ë. III. "(portion only), 5 Hen. VI. to 1800 .

\section{Exchequer Rolls.}

1. Pipe or Great Rolls.

2. Reccipt Rolls.

3. Issue Rolls.

4. Memoranda Rolls.

Inquisitions. (Very few before Henry VII.)

Misc. Rolls (Chancery). (Indexed in Rec. Com. Report, I819, pp. 518-20. Hardly anything except exemplifications before Henry VII.)

Christ Church Deeds. 1174-1684.

During the mediæval period the Irish records, especially those of the Dublin Exchequer, found their way in considerable numbers to Westminster (cf. Red Book of Exchequer [Rolls] Vol. III., P. 977). These are calendared down to the year 1307 , with extracts relating to Ireland from the English series, in the Rolls Calendar (No. I302), a work of the greatest economic interest. Compared with the Scottish Records, very few texts or calendars of the medixval records of Ireland have been published officially, and these chiefly for a later period. During recent years a calendar of the Justiciary Rolls dating from 1295 has been begun and will be found of the utmost value. Some attention has been given to the Irish Records in the publications of the Royal Irish Academy and other learned societics, as well as, more recently, by individual scholars. 


\section{A.-Diplomatic Documents.}

1293. Calendars of Ancient Charters, etc., to which are added Memoranda concerning the affairs of Ireland extracted from the Tower Records (J. Ayloffe). I 774 .

1294. Dublin, Calendar of the Ancient Records of (J. T. Gilbert). Dublin, I889, etc.

I295. - "Crede Mihi," the most ancient Register Book of the Archbishops of (J. T. Gilbert). Dublin, 1897 .

1296. - Register of Wills and Inventories of the Diocese of, I457-1483 (H. F. Berry). Royal Soc. of Antiq. of Ireland. Extra vol., 1896-7. Dublin, I898.

1297. Irish Record Commission. Chartae, Privilegia et Immunitates, I I7 I-1 395. Dublin, 1829-30.

1298. Liber Munerum Publicorum Hiberniae, II 52-I 827. I 824-30.

1299. - Rotulorum Patentium et Clausorum Cancellariae Hiberniae Calendarium, Henry II.Henry VII. Dublin, I 828 .

I300. Historical MSS. Commission. Gormanston Register (J. T. Gilbert, Rept. IV., Appendix). I 874 .

1301. Limerick, Black Book of (J. MacCaffray). Dublin, 1907.

1302. Public Record Office (London). Calendar of Documents relating to Ireland in the. 1875, etc.

1303. - (London). Calendar of Documents preserved in France illustrative of the History of Great Britain and Ireland (J. H. Round). 1899.

1304. - (Ireland). Christ Church Deeds, Calendar of. (Deputy-Keeper's Reports, XX., App. VII.; XXIII., App. III.; XXIV., App. VIII.) Dublin, I 888-I892. 
1305. Rolls Series. Carew Manuscripts, Calendar of (The Book of Howth, The Conquest of Ireland, etc.) (J. S. Brewer and W. Bullen). I87I.

1306. Dublin, Cartularies of St. Mary's Abbey at (J. T. Gilbert). 1884.

1307. Historic and Municipal Documents of Ireland ( $\mathrm{J} . \mathrm{T}$. Gilbert). I 870.

1308. - Irish Documents, Calendar of documents relating to Ireland, II II-I 307 (H. S. Sweetman). I 875-86.

\section{B.-Ministerial Proceedings.}

1 309. Derry, Act of Archbishop Cotton in his visitation of the Diocese of, I397 : with a rental of the See Estates (W. Reeves). Irisb Archaol. Soc. Dublin, 1850.

1310. Cloyne Pipe. Rotulus Pipae Clonensis (R. Caulfield). Cork, I859.

I3I I. Ecclesiastical Antiquities of Down, Connor, and Dromore, consisting of a taxation of those dioceses compiled in the year I306 (W. Reeves). Dublin, I 847 .

1312. Historical MSS. Commission. Taxation of the diocese of Ossory by Bishop Richard Lederede, c. 1320. Report X., pt. 5. 1885.

1313. Public Record Office (London), Calendars of Documents relating to Ireland in the. 1875, etc.

1314. Record Office, Ireland. Pipe Rolls of the Irish Exchequer: Catalogue of Accounts in Reports of the Deputy-Keeper, XXXV., XXXVI., XXXVII., XXXVIII., XXXIX., Dublin, 1903-1907.

\section{C.-Judicial Proceedings.}

1315. Ancient Laws of Ireland (Commission for publishing the Ancient Laws and Institutes of Ireland: W. N. Hancock and R. Atkinson). Dublin, 1865-1901. 
1316. Book of Rights (J. O'Donovan). Celtic Soc. Publications. Dublin, 1847 .

I317. Inquiry into the Ancient Corporate System of Ireland . . . with an appendix containing numerous original documents (P. Gale). 1834 . I3i8. Public Record Office (London), Calendars of Documents relating to Ireland in the. I 875 , etc.

\section{D.-Miscellaneous Records.}

I3 I9. Rolls Series. King's Council in Ireland, Roll of the proceedings of, I392-93 (J. Graves). 1877 .

1320. Irish Record Commission. Liber munerum Publicorum Hiberniae. (The Establishments of Ireland, etc., I 152-1827). I 824-I852. See also No. 1298.

1321. Record Office, Ireland. Statutes and Ordinances and Acts of the Parliament of Ireland, King John to Henry V. (H. F. Berry). Dublin, I907.

1322. - Statute Rolls of the Parliament of Ireland : Reign of Henry VI. (H. F. Berry). Dublin, I9IO.

1323. Justiciary Rolls of Ireland, Calendar of the (J. Mills). 1905.

1324. Statutes at Large passed in the Parliament of Ireland, I310-1786 (F. Vesey). Dublin, I786. 1325. Vitae Sanctorum Hiberniae (C. Plummer). Oxford, I9Io.

\section{III.-WALES.}

Under the existing arrangement all mediæval Welsh records are actually included in the English series. It is said that these records were formerly kept apart under the press-mark of Wallia, and many Accounts of royal ministers were apparently in the custody of the Auditors of the Land Revenues for 
Wales. The later Judicial records, from 1543 onwards, were formerly preserved in Welsh repositories, but were transferred to London in 1854 . As to their value, see the Report of the Deputy-Keeper of the Public Records, and the essays by R. A. Roberts (No. 166) and H. Hall (No. 167). It should be carefully observed, however, that the medixval records of the County Palatine of Chester, which are of great economic interest, are no longer regarded as Welsh Records, although those of Flintshire are claimed as such. Some of the Chancery series of Welsh Rolls have been recently calendared in the Record Office Series. No calendars or texts of Welsh Records are published in a Government collection as in the case of the Scottish and Irish Records and "Documents."

The series that will probably be found most useful for medixval economic history are the following, but with the exception of the summary calendars printed in early Reports of the Deputy-Keeper and a scholarly edition of some Chester "Chamberlain Accounts" none of these have been published:

Minister's Accounts (General Series).

Court Rolls (General Series).

Forest Proceedings (Chester Records).

Quo Warranto Rolls (Chester Records).

Plea Rolls, Assize Rolls, etc. (Chester and Flint).

Welsh Rolls (Chancery).

There are apparently no printed lists or texts of Welsh local Records, but notices of some of those still in the custody of Clerks of the Peace will be found in the Deputy-Keeper's Reports and the Reports on the Public Records in 1800 and 1837 . These are probably all of post-medixval date. The Welsh mediæval literary MSS., including the Ancient Laws and such extents and cartularies as have survived in private custody, have been to some extent printed in the Historical Manuscripts Commission Reports (by 
Dr. Gwenogvryn Evans), in the Record Commission Series, and by Welsh societies or private scholars. Of late years fine collections of early deeds and other documents have been acquired and arranged by the libraries at Aberystwyth and Cardiff.

\section{A.-Diplomatic Documents.}

1326. Calendar of Ancient Charters and Scottish, Welsh, and Irish Rolls, I276-I295 (Sir J. Ayloffe). I 774 .

1327. Glamorgan, Cartae et alia Munimenta quae ad Dominium de Glamorgancia pertinent (G. T. and G. L. Clark). Cardiff, I9ıo.

I328. Montgomery, Ancient Charters of the Borough : Henry IV., etc. With a translation. Powysland Club. Swansea, 1845 .

1329. Neath, Original Charters and Materials for a History of (G. G. Francis). Swansea, I845.

1330. Record Office. Welsh Records, Calendar of deeds, inquisitions, and writs enrolled on the Plea Rolls of Chester, 40 Henry III. to 38 Henry VIII. Deputy-Keeper's Reports. I $865-9$.

133I. Rolls Series. Letters, Royal and Historical, during the reign of Henry IV. relating to affairs of Wales, etc.; Vol. I., I399-I404 (F. C. Hingeston). I 860.

1332. Strata Florida Abbey, I I66-I 540: Documents and Charters connected with the History of. Archaologia Cambrensis, Vol. III., pp. 19I2I3. I848.

1333. Swansea, Charters granted to, the Chief Borough of the Seignory of Gower, I215-1837; with a translation (G. G. Francis). I 867 .

\section{B.-Ministerial Proceedings.}

I334. Baronia de Kemeys, from the Original Documents at Bronwydd. Cambrian Archaol. Assoc. I86I. 
I334A. Black Book of St. Davids (J. W. Willis Bund). Cymmrod. Soc. 1902. (Extents, 1326.)

1335. Cardiganshire, Minister's Accounts, 1277-80. Cymmrodorion Soc. Trans. $1895-6$.

1336. Expenses of Edward I. in Wales, 1281-82: Roll of (S. Lysons, with a translation by J. Brand). Archaologia, Vol. XVI., pp. 32-79. 18 I 2.

1337. Merioneth, Extracts from Sheriff's Roll of, 1308-9. Cymmrodorion Soc. Trans. 1902-3.

1338. Record Commission. Taxatio Ecclesiastica Angliae et Walliac Auctoritate Nicholai IV. I 802 .

I338A. The Record of Carnarvon (Sir H. Ellis). 1838.

1339. Rolls Series. Giraldi Cambrensis Opera. Itinerarium Kambriac. Descriptio Kambriae. (J. S. Brown, J. F. Dimock, and G. F. Warner.) I86I-9I.

\section{C. - Judicial Proceedings.}

1340. Bowen, Ivor. The Statutes of Wales. 1908.

I34I. Clive, R. H. Documents connected with the History of Ludlow and the Lords Marchers. 1841 .

1342. English Law in Wales and the Marches $(H$. Owen). $Y$ Cymmrodor, Vol. XIV. 1900.

1343. Lewis, Hubert. Ancient Laws of Wales, viewed in regard to the light they throw upon the Origin of English Institutions (J. E. Lloyd). 1889.

1344. Owen, George. Description of Pembrokeshire, with chapter on the Lordships Marchers in Wales (H. Owen). Cymmrodorion Record Series, Vol. I. 1906.

1345. Record Commission. Ancient Laws and Institutes of Wales (Aneurin Owen). 1841 . 
1346. Record Office. Welsh Records: Calendar of Fines, Counties of Chester and Flint, Edward I. Deputy-Keeper's Reports, XXVII., 6-19. 1867.

1347. Ruthin, The Court Rolls of the Lordship of, or Dyffryn-Clwyd, of the reign of King Edward the First, preserved in the Public Record Office. Cymmrodorion Society, Vol. II. 1893. 1348. Welsh Mediæval Law (A. W. W. Evans). Oxford, I909.

\section{D.-Miscellaneous Records.}

1349. Barddas : or a Collection of Documents . . illustrative of the . . . Bards-druidic system of the Isle of Britain (J. Williams). Society for the Publication of Ancient Welsh MSS. Llandovery, I862-74.

1350. Llandaff [Liber Landavensis]. The text of the Book of Lan Dâv (J. G. Evans and J. Rhys). Series of $W$ elsh $\mathcal{T}_{\text {exts. }}$ I 893 .

I35I. Owen, G. Description of Pembrokeshire $(\mathrm{H}$. Owen). Cymmrodorion Society, Record Series I. I892, etc.

1352. Rhewallon and his Sons. The Physicians of Myddvai; Meddygon, Myddfai, or the medical practice of . . (J. Williams). Society for Publisbing Ancient Welsb MSS. Llandovery, I86I. 


\section{Section III. \\ England's Continental Neighbours.}

FrANCE.

The French Archives were nationalised at the Revolution, and since that date the whole of the central and local archives have been carefully preserved and systematically arranged and described by a class of professional archivists which has been established by the Governments of every great European country with the exception of our own. The Archives Nationales in Paris represent the proceedings of the Chancery, Council, Parliament, and Ministries. The system of classification will be seen from the Table of Contents of the Etat Sommaire (No. I68).

The Archives Départementales, which represent our own "Local Records of a Public Nature," have been (unlike our own) safely preserved in official custody since the Revolution. For the subject of medirval Economic History the two divisions of Archives Civiles and Archives Ecclesiastiques, anterior to I790, should be consulted. The literature of these archives is given in Langlois and Stein, but later information will be found in official Reports and in the special historical periodicals mentioned above (pp. 20-2I). In addition to journals like the Bibliotbeque de l'Ecole des Chartes, in which an immense number of pieces are printed or described, mediæval documents preserved in the national and departmental archives are published in the great series of Documents inédits, and to some extent by learned societies. Individual works like that of Fagniez (No. 1464) also give texts of economic interest.

Besides the State archives and the publications derived therefrom, French scholars have been busily engaged for long past in publishing descriptions or texts of documents concerning French history in 


\section{I46 A SELECT BIBLIOGRAPHY OF}

foreign archives, and many of these, e.g., Publications of the Ecole française at Rome, are of interest for English economic history (No. 1605). Similarly, the edition of the Rôles Gascons (No. 868), by Chas. Bémont, is most important. The texts of Chancery Privy Seals, etc., published by E. Déprez, should not be overlooked, and even the earlier collections of J. Delpit are indispensable to French and English students alike.

The Archives Municipales, Communales, Hospitalieres, which represent our own Local Records, not of a public nature, together with certain private collections of Historical Manuscripts, were less fortunate than the State archives, inasmuch as not having been brought into official custody at the Revolution, they were decimated by the vandalism of the early 19th century. Since the middle of that century they have been under the care of a Commission des Archives; but, with the exception of the larger towns, the proportion of mediæval documents that has survived is small. The literature of these archives is given in the work of Langlois and Stein, but many later inventories have been published. Reference should again be made to the work of Fagniez.

Libraries like the Bibliothèque Nationale have a literature of their own, and the provincial libraries are described in Langlois and Stein.

Private collections or Historical Manuscripts (Archives Diverses) are also described in the above work; but, with the exception of the muniments still remaining in the hands of ecclesiastics, they are far less important than similar muniments in England.

\section{Belgium (Flanders, etc.).}

The state of the Belgium archives has been well described by MM. Gachard (184), Gaillard, and Cuvelier (No. I8I), as well as by Langlois and Stein (No. 191), and their system is largely based on the 
French. In fact, the archives of Belgium were systematised during the French occupation. Since 1831 there have been central archives at Brussels (Archives Générales du Royaume) and eight or nine provincial repositories (Archives de l'état dans les provinces) under the supervision of the chief archivist at Brussels. The Belgium State archives are rich in medixval charters or cartularies and accounts, and these have been extensively printed by the Brussels Academy and to some extent by learned societies or individual scholars. The pieces printed by Varenbergh (No. 2071) are valuable for economic history, but most of these and the materials for the medixval cloth trade are found in the communal archives. In the central archives at Brussels, howcver, as well as in some local archives, many unpublished medirval documents (chicfly accounts, registers, and cartularies) may be found which might throw light on several obscure aspects of medixval economic history.

In addition to inventories and a few texts edited by earlier archivists, the most important publications from the Belgian archives have been included in the several series produced by the Commission royale d'Histoire attached to the Académie royale de Belgique, e.g., the Documents inédits rélatifs à l'histoire de Belgique. Even more important for economic history are the publications of the Commission royale pour la publication des anciennes Coutumes Lois et Ordonnances de la Belgique, though few of the existing codes are dated in the medixval period. Some texts have been published from the local archives by historical societies as well as in the historical reviews and other periodicals. A few titles are given below, and others will be found in the directories cited elsewhere (No. 196).

The Local Records of the southern provinces of the medirval Low Countries are chiefly represented by the municipal and communal archives of Bruges, 
Ghent, Ypres, and other cities and towns, the general nature of which is described in the works of MM. Langlois and Stein, Potter and Brockaert, Cuvelier, and others. In Belgium, as in other Continental States, the important collections of municipal archives are looked after by expert archivists. One result of this interest is the preparation of inventories of the archives, many of which are printed. Again, the local archives are an object of solicitude to the several State or academic Commissions which direct the official publications of the nation. Besides the municipal archives there are many valuable documents to be found amongst the "Archives diverses," namely, the historical manuscripts in the possession of the churches, convents, notaries and families. These, the "Petites Archives," as they have been called. are for the most part of post-mediæval date, but many cartularies and other muniments have been published or described by the Brussels Academy and local historical societies, whilst still more remain to be dealt with.

It may be remarked here that the taste for publishing chronicles has taught historians the value of charters, accounts, and other formal documents as incidental sources of historical information. It should also be noted that there is much in common between the local historical sources of the Low Countries and the North of France, whilst many Flemish documents may be found in Paris.

\section{Netherlands (the Low Countries).}

The State Archives of the Netherlands, like those of Belgium and France, are primarily classified according to the great political changes in the national constitution at the close of the 18 th and during the first part of the 19th century. Thus the earliest series of State documents is that prior to 1796 , and this is 
followed by the documents accruing during the French occupation (1796-18I4), archives of the united kingdom of Holland and Belgium (1814-1830), and the purely Dutch archives since the revolution of 1830 . The Belgian archives are divided into three similar epochs, with the difference of date between 1794 and 1796, whereas the French archives, as we have seen, are simply divided as anterior or posterior to the year 1790 .

The medirval value of the Dutch Archives is perhaps scarcely as great as those of Belgium. The General National Archives (Algemeen Rijks archief) at the Hague, also include the provincial archives for South Holland, those for North Holland being preserved at Haarlem. The remaining provinces also possess well-equipped State archives (Rijks-archieven). The mediæval contents of these archives have not been exhaustively published or described, except in the case of Utrecht. At the same time it should be noted that the documents most interesting for English economic history are to be found in the municipal archives of the Netherlands, although in some cases these are practically in the same custody as the State archives.

The Municipal Archives (Gemeente-Archief) are to be found in the cities and principal towns of every province. They are usually distinguished as "old" (oude) and " new" (nieuwe) archives respectively, the former being transformed to a public repository and the latter remaining in the custody of the town clerk (sekretaris).

There are also separate archives relating to the Waterways (Waterschaps-Archieven), but these are comparatively modern and, like those of our own Commissioners of Sewers, are mostly in the hands of local authorities. Two other noticeable collections in municipal archives may be regarded as negligeable for our present purpose. These are the Archives of the Vendue (Veender-y-archieven), which are also modern, 
and have only survived in a few provinces) and the Church Books. The latter include the Registers of Births, etc., and other administrative archives, the charters, registers, and more ancient documents having been incorporated for the most part with the State or municipal archives.

A good description of the early sources is given in P. J. Blok's " History" (Appendix), but the Reports (Verslagen) of Professors Blok and Brugmans on the English archives, so far as they concern the history of the Low Countries, are unfortunately chiefly confined to the post-mediæval period, though the new State Commission for Publications has published some useful reports on mediæval Baltic and Italian archives. (No. 210 ).

The position of the local archives, other than those of an official nature, in the Netherlands closely resembles that of the Belgian collections, though the former are more numerous and important than the latter. The archives of the Protestant Churches and the contents of the public libraries are useless for our subject, and those of private families are comparatively rare.

The archives of the Grand Duchy of Luxembourg are of considerable extent, and have been described in the Missions des Archives (1888). Texts have been published by the Grand-ducal Institute of Luxembourg.

Germany, etc. (the Mediatal Empire).

The State archives (Staatsarchive) are numerous, ranging from eighteen, in Prussia, down to a single repository. The typical collection is described as "Royal," "Princely," "Ducal," etc., and is essentially "secret" (Geheimes archiv), besides often containing a section which concerns the reigning house (Hausarchiv). In Bavaria there are "Circuit" archives (Kreisarchiv), and in Alsace-Lorraine "District" 
archives (Bezirkarchiv). The terms "national," "general," and "central" also occur. In the free cities of Hamburgh, Bremen, and Lübeck, and in many of the German States, there are "state" archives.

Perhaps more local interest has been taken in the archives of the Rhine cities than in those of other districts of the Empire, and these are also valuable for the Hanseatic trade, together with the archives of the free cities and certain Prussian collections, particularly Stettin, Dantzig, Osnabrück, Königsberg, and Magdeburg. The archives of Baden are interesting for agrarian history.

During recent years much attention has been given to the science of archives in Germany and AustriaHungary, and great progress has been made in this direction. On the other hand, the fact remains that Burkhardt's Hand-und-adressbuch (No. 195) has not been revised since $\mathbf{I} 887$, and foreign students are glad to have access to the lists published by Hettler (Nos. 196-199) although they have no pretensions to scholarship. At the same time it should be noted that the great majority of the German state archives are later than the mediæval period, with the exception of those of the free cities. In any case the official literature of the state Archives is very meagre for that period, nor (with the following exceptions) are the publications of local archives of particular interest for English mediæval history.

The German cities are rich in diplomatic documents of early date, and many texts of these (Urkundenbücher) have been published. The archives of the old cities of the Hanseatic League are particularly valuable. Amongst the "Stadt-archive," the "Rathsbücher" (Council registers) and "Schuldbriefe" (bonds, etc.) should be noticed.

Some of the states or cities publish inventories or transactions for their archives; but for the most part information must be sought for in the publications 
mentioned above, and in local journals or academies. The same remark applies to the archives of AustriaHungary and Switzerland in respect of early economic subjects. As in England, the extensive and scholarly publications of the Governments or of royal commissions and learned societies are chiefly concerned with political and constitutional subjects. Some collections and periodicals of special interest are given below.

\section{Italy (ItTalian States).}

There are nearly a score of separate Archives of State (Arcbivio di Stato), of which those at Venice, Milan, Genoa, Pisa, Lucca, Florence, and Naples are perhaps the most important for English mediæval economic history.

For the Vatican Archives there is, as we have seen, a distinct and cosmopolitan literature. For the earlier history, see H. Bresslau's "Urkundenlehre."

It is naturally a question for careful consideration whether English students would find it worth while to make independent researches in the Vatican and Venetian archives, in view of the work that is being carried on there by the Record Office agents. At the same time the official transcripts (the originals of the published calendars) have been made as opportunity served, and without any special interest in economic subjects. The notices of the condottieri and English archers, to be found in the Venetian calendar, are supplemented from the Archives of Milan in a recent volume. In the case of the Tuscan Archives much more has been published by the historical Commissions, as well as by private enterprise, and texts of the early Italian Laws and Charters are given in the series of Monumenta Storia Patria. There is also an extensive foreign literature which is especially valuable for the mercantile relations of the Italian cities with other mediæval states. 
The communal archives are of somewhat later date. The municipal archives, both printed and in manuscript, are partially described in Manzoni's Bibliografia dei Municipii (1876-92). In some cases the municipal archives are placed in the civic Museum, as at Padua. However, the Italian local records are of less importance for our subject than the State Archives, as the chief cities were formerly independent states.

Spain and Portugal ('The Peninsular Kingdoms).

Although a system of centralisation has prevailed for more than a century (facilitated by the proprietary interest of the Crown in the chief archives, libraries, and museums), the custody of these is still for the most part associated with the old kingdoms or provinces of Castille and Leon, Aragon (including Valencia and Catalonia), Galicia, Navarre, and Portugal. Thus, in addition to the Archivo General Central outside Madrid and the other well-known Castilian repositories at Seville and Simancas, archives are still preserved at Barcelona (Aragon), Valencia, Pampeluna (Navarre), Galicia, and Palma (Majorca); whilst the royal archives of Portugal are mainly preserved at Lisbon. It has been observed (above, p. 27) that inventories of these collections have only been partially printed, and chiefly in periodical publications. Various descriptive accounts of the same have been published by native or foreign antiquaries. Reference should also be made to the publications of the Royal Academies and Learned Societies, as well as to certain Periodical Publications and other Collections noted below.

In addition to these Royal and Departmental Archives, extensive collections of historical MSS. may be found in the several royal libraries of Madrid, as well as in the possession of the Cathedral Churches, Cities, Universities, Royal Academies, and Lcarned Societies of Spain and Portugal. Catalogues of some 
of these libraries have been published, and further information may be found in the Annuario (188I, etc.) and the various Boletins of the learned institutions.*

\section{Denmark, Norway and Sweden.}

The Scandinavian kingdoms have so many affinities in respect of history, constitution, language and literature, and these resemblances have reacted so strongly on their respective archives and historical studies, that it will be more convenient to give a brief description of their common features of interest for English students.

In each kingdom there are central or metropolitan archives, provincial archives (centralised in a few repositories), and public or private collections in the possession of libraries, corporations, and learned societies or individuals.

Thus for Denmark, besides the Rigsarkiv in Copenhagen, there are three provincial depots at Copenhagen, Odensee, and Viborg, with the contents of the private collections alluded to above. In Christiania, and in Stockholm, there is a Rigsarchiv, and there are provincial state archives and private collections in both Norway and Sweden, those of the latter country being especially valuable. Besides the archivistic periodicals mentioned above (p. 29) each of the Scandinavian kingdoms has published a Diplomataria of great interest for mediæval history (p. 178), whilst the historical and antiquarian societies publish the results of many original researches in archives. At the same time the great bulk of the state archives being later than the mediæval period, many historical publications do not concern us here.

Although the Scandinavian kingdom of Norway was more in evidence to English traders and chroniclers from the 12 th to the $14^{\text {th }}$ centuries, Denmark plays

$\therefore$ cf. R. Beer, Mittelalterliche Bibliotheken Spaniens (in Allgemeine Zeitung (1895); P. Ewald, Codices MS. ad historiam medii avi (1881); Reoue internationale des Bibliotbèques (1895-6). 
an important part in connexion with the Hanseatic League from the end of the $14^{\text {th }}$ century.

Even more important for English students are the recent researches of Professor Alexander Bugge as to the relations between the Celtic, Norman, and Scandinavian inhabitants of Ireland before the $13^{\text {th }}$ century and the trade relations between England and Scotland, and Norway from the 12 th to the 15 th century. The results of the latter investigations have partly appeared in the Diplomatarium Norvegicum, and show that many series of English Public Records throw light on these obscure trade relations. The muniments of the city of London are disappointing for this subject, but some amends are made by those of King's Lynn and other out-ports.

\section{FRANCE.}

\section{Diplomatic Documents.}

1353. Cartulaire normand de Philippe-Auguste, Louis VIII., Louis IX. et Philippe le Hardi (L. Delisle). Mém. des Antiq. de Normandie XVI. 1852 .

1354. Cartularius antiquus ecclesiae Baiocensis (V. Bourrienne).

1355. Cartulaire de l'abbaye de Saint-Victor de Marseille (B. Guérard). Coll. de Documents. 1857.

1356. Cartulaire de l'abbaye de Saint-Bertin (B. Guérard). Coll. de Documents. 1840.

1357. Cartulaire de Saint-Jean-en-Vallée de Chartre (R. Merlet). 1906.

1358. Cartulaire de Sainte-Croix d'Orleans (J. Thillier and C. von Jary). Mem. de la Soc. Archéol. et hist. de l'Orléanais, XXX. 1906.

1359. Cartulaire municipal de la ville de Villefranche (A. Besançon). 1907. 


\section{I56 A SELECT BIBLIOGRAPHY OF}

1360. Cartulaires de l'abbaye de Molesme, 916-1250.

T. Ier Introduction. (J. Laurent.) 1905.

1361. Cartulaires de l'Yonne (M. Quantin). I873.

1362. Cartulaires de la Bourgogne (J. Garnier). I $867-8$.

1363. Cartulaires du diocèse de Carcassonne(A. Mahul) I 857 .

1364. Cartulaires de l'ordre des Hospitaliers (J. Delaville le Roulx). I 885 .

1365. Cartulaires de Paris (R. de Lasteyrie). I 899.

1366. Cartulaire municipal de Lyon (C. Guigue). I876.

1367. Cartulaire municipal de Manosque, II69-1315 (M. Z. Isnard). I894.

1368. Cartulaire noir de la cathédrale d'Angers (Ch. Urseau). 1908.

1369. Cartulaire de la ville de Blois (J. Soyer and G. Trouillard). 1907 .

1370. Cartulaire de l'abbaye de Saint-Aubin d'Angers (B. de Broussillon. Doc. historiques sur l'Anjou, Vols. I.-III. I 896-1903.

1371. Cartulaire de Berdoues (ed. Cazauran). 1905.

1372. Cartulaire de la Chartreuse du Val de SainteAldegonde (J. de Pas). Soc. des Ant. de la Morinic. 1905.

I373. Cartulaire du chapitre de Sens (E. Chartraire). Soc. Archéol. de Sens, VIII.

1374. Cartulaire de l'abbaye de Lérins (H. Moris).

I375. Cartulaire de l'abbaye de Gimont (A. Clergeac). Archives historiques de la Gascoyne. 1905.

1376. Cartulaire de l'abbaye de Notre Dame de la Merci Dieu . . . de Poitiers (E. Clouzot). Archives hist. de Poitou, XXXIV. 1905.

1377. Chartes Anglo-Normandes. Evreux, 1908, etc.

I378. Longnon, Auguste. Paris pendant la Domination Anglaise : documents, extraits des registres de le Chancellerie de France. 1878. 
1379. Mas-Latrie, L. De. Recucil des traités de paix et de commerce conclus au moyen-âge entre les chrétiens et les Arabes de l'Afrique septentrionale. 1865 .

1380. Robert, U. Testaments de l'officialité de Besançon. Coll. de Documcnts. 1907.

I38I. Round, J. H. Calendar of Documents, France. Public Record Office, London. 1899.

1382. Vautier, C. Extrait du registre des dons, etc., faits dans le duché de Normandie pendant I418-20 par Henri V. 1828.

\section{Ministerial Proceedings.}

Accounts.-Royal: Norman Exchequer.

1383. Grands rôles des échequiers de Normandie (A. Léchaudé d'Anisy). Mém. de la Soc. des Antiq. de Normandie, t. XV. 1845.

1384. Actes normands de la chambre des comptes sous Philippe de Valois (L. Delisle). Soc. dé l'hist. de Normandie. 1871.

1385. Jugements de l'echequier de Normandie au XIIIe siècle, I 207-70 (L. Delisle). I864.

1386. Etablissements et coutumes, assises et arrêts de l'échequier de Normandie au XIIIe siècle, I 207-45 (A. J. Marnier). I 839.

1387. Fragments des comptes du XIIIle siècle (L. F. Bourquelot). Bib. de l'Ecole des Chartes, XXIV.

1388. Compte du trésor du Louvre, 1296 (J. Havet). Bibl. de l' Ecole des Chartes, XLV.

1389. Compte des dépenses de la maison de la reine Blanche de Castille, I24I (E. S. Bougenot). Bull. du Comité, Histoire and Philologie. 1889.

1390. Le compte des recettes et dépenses du roi de Navarre en France et en Normandie, 13671370. (Publié par E. Izern avec un introduction par G. A. Prévost). 1880. 
1391. Le compte des recettes et dépenses du roi de Navarre en France, 1367-70 (J. Clemence). 1885 .

I392. Les Comptes du roi René (G. Arnaud d'Agnel). 1908.

1393. Comptes royaux de la période de Charles VI. (A. Vallet de Viriville). Cabinet historique, t. III. and IV.

1394. Dersalles, L. Rançon du roi Jean. Compte de l'aide imposée pour la delivrance de ce prince . . . 1369-70 (L. Dersalles). 1850.

1395. Douet D'Arce, L. Comptes de l'argenterie des rois de France au XIVe siècle. Soc. de l'Hist. de France. $185 \mathrm{I}$.

I396. - Nouvelle recueil des comptes de l'argenterie des rois de France, I317-1 387. Soc de l'hist. de France. 1874 .

1397. Extraits des comptes et mémoriaux du roi René (A. Lecoy de la Marche). 1873.

I398. Inventaire de Robert Mignon (Ch. V. Langlois). Recueil des historiens de la France. Documents financiers, I. I899.

Municipal.

1399. Comptes d'Agen (G. Tholin et A. Magen). I 892.

I400. Comptes d'Albi (A. Vidal). 1900.

I40I. Comptes de Blois (J. Soyer). 1903, etc.

I402. Comptes d'Orléans (B. de Molandon et F. de Villaret). 1882 .

I403. Comptes de Rouen (J. Félix). 1893.

I 404. Registres des comptes municipaux de la ville de Tours, I358-80 (J. Delaville-Le Roulx). I878-188I.

Private.

1405. Les comptes concernant . . l'hôtel des comtes de Flandre, du Hainaut et des ducs de Bourg. (J. Finot). 
1406. Comptes de Jacme Olivier, marchand de Narbonne au XIVe siècle (E. Forestié). I899, etc.

1407. Comptes du receveur de la vicomté de Valernes, 1401-I408 (M. Z. Isnard). 1905.

1408. Inventaires mobiliers et extraits des comptes des Ducs de Bourgogne de la maison de Valois, 1363-1477. 1902-8.

1409. Le Livre des comptes des frères Bonis, marchands montalbanais du XIVe siècle. (E. Forestié.) Archives Historiques de la Gascogne 1890-1 894.

1410. Registre de Pierre de Ham, bailli de Calais, I $344-67$ (J. M. Richard). I 894 .

1411. Livre de Guy de la Trémoille et de Marie de Sully, I 395-I 406 (Duc de la Trémoille). 1887.

1412. Les La Trémoilles pendant cinq siècles (Duc de la Trémoille). 1890.

1413. Longreaux, C.-P. DE. La Chambre des comptes du duché de Bar (De Dumast). 1907.

Inquisitions, etc.

1415. Delisle, L. V. Chronologie des taillis et des sénéchaux royaux depuis les origines jusqu' à l'avènement de Philippe de Valois, 11961327. M. Bouquet, Recueil des Historiens des Gaules, t. 24. I904.

1416. Langlors, $\mathrm{C}_{\mathrm{H}}-\mathrm{V}$. Doléances recueillies par les enquêteurs de St. Louis et des derniers Capétiens directs. Revue Historique. I906, 1909.

\section{Judicial Proceedings.}

Royal Acts, Etc.

1417. Baluze, E. Capitularia regum Francorum. I677 (P. de Chiniac). I 780.

I418. Boretius, A. Capitularia regum Francorum. T. I. Monumenta Germania historica. Legum sectio, 11 . 1881-3. 
I4I9. B. Guerard, Capitulaire de Villis. Bib. de l'Ecole des Chartes. Series 3, IV.

1420. Havet, Julien. Les Cours Royales des Iles Normandes. Paris, 1878 .

I42I. Recueil général des anciennes lois françaises de 420-1789. (F. Isambert, A. Jourdan, and Decrusy.) I $872-7$.

1422. Ordonnances des rois de France de la troisiéme race jusqu'en I514. (Rec. dit des Ordonnances du Louvre. 1723-1 849.)

1423. Recueil d'actes des XIIe et XIIIe siècles en langue romane wallonne du nord de la France (E. Tailliar). I 849.

1424. Recueil des actes de Lothaire et de Louis V., rois de France, 954-987 (L. Halphen). 1908.

1425. Recueil des Actes de Philippe Ier, Roi de France, 1059-1 108 (M. Prou). 1908.

1426. Actes du Parlement de Paris (E. Boutaric). $1863-7$.

1427. Rouleaux d'arrêts de la cour du roi au XIIIe siècle (Ch. V. Langlois). Bibl. de l'Ecole des Chartes, XLVIII.

1428. Les Olim, ou Registres des arrêts rendus par la cour du Roi (A. Beugnot). Coll. des Documents Inédits. I $839-48$.

1429. Inventaire des arrêts du conseil d'état (Noël Valois). T.r. 1886.

1430. Collection des lois maritimes antérieures au XIIe siècle (J. M. Pardessus). I 828-45.

143I. Collection des lois, ordonnances et réglements de police depuis le XIIIe siècle (J. Peuchet). I8I 8-I9.

Episcopal Registers, etc.

1432. Delisle, L. Rouleax des morts du IXe au XVe siècle. Soc. de l'Hist. de France. I 866.

1433. Denifle, $H$. Documents relatifs à la fondation de l'université de Paris. I884. 
1434. Denifle, H., and Chatelain, E. Chartularium Universitatis Parisiensis. 1894.

1435. Régestes des évêques de Thérouanne, 500-1 553 (O. Bled). Soc. des Antiquaires de la Morinie. 1902-7.

1436. Regestrum visitationum archicpiscopi Rothomagensis. Journal des visites pastorales d'Eudes Rigaud, archevêque de Rouen, 1248-69 (E. Bonnin). 1852 .

1437. Simon de Beaulieu, archevêque de Bourges, primat d'Aquitaine, I28 I-94. Procès verbaux de ses visites comme métropolitain et comme primat dans les provinces de Bourges et de Bordeaux, 1284-91. (E. Baluze.) Miscellanea, de la Soc. des Etudes . . . du Lot. I901.

Municipal Registers.

1438. Livre des Syndics des Etats de Béarn, XIVe et XVe siècles (L. Cadier). I 880.

1439. Registres consulaires de Limoges (E. Ruben and P. Ducourtieux). I 885 , etc.

1440. Registres consulaires de Lyon (C. Guigue). T. Ier. 1887.

I44I. Registres consulaires de Saint-Flour (M. Boudet). 1898.

1442. Registres de déliberations de la ville de Troyes (A. Roserot). $\quad$ I 886.

1443. Registres des échevinages de Saint-Jeand'Angély (Denis d'Aussy). I 895.

1444. Registres des jurades de Bordeaux. $1887 \mathrm{ff}$.

Custumaries.

1445. La Compilation de Bouhier et les coutumiers bourguignons du XIVe siècle: le coutumier bourguignon de Montpellier (Champeaux). 1907.

1446. Coutumes et institutions de l'Anjou ct du Maine (C. J. Beautemps-Beaupré). 1877. 
I447. Coutumes de Beauvaisis (ed. A. Salmon). I 899-1900. (See also 1460.)

I448. Coutumier de la Bretagne (M. Planiol). I 896.

1449. Coutumiers de Normandie, Ire partie. Le très ancien coutumier de Normandie (E. J. Tardif). I88I.

1450. Le Coutumier général (C. Bourdot de Richebourg). 1724 .

I45 I. Etablissements de Rouen (A. Giry). 1885.

1452. Etablissements de St. Louis (P. Viollet). Soc. de l'Hist. de France. 1882-4.

1453. Franchises, lois et coutumes de la ville de Lille (E. Brun-Lavaine). 1842.

1454. Le Grand Coutumier (W. L. de Gruchy). I88I.

1455. Le Grand et Le Petit Thalamus à Montpellier (A. Germain).

1456. Livres des Bouillons (J. Delpit). Archives municipales de Bordeaux. 1867.

1457. Livre des établissements de Bayonne. I892.

1458. Le Livre Noir et les Etablissements de Dax. (F. Abbadie.) Soc. des Archives Hist. de la Gironde. 1902.

I459. Livre Rouge de l'hôtel de ville de Saint Quentin (E. Lemaire). $188 \mathrm{r}$.

1460. Beaumanoir, Philippe de. Coutumes de Beauvaisis (ed. A. Beugnot). Soc. de l'Hist. de France. 1842. (See also No. 1447.)

1461. Statuts et Coutumes des échevinages de Mézières et d'Ivoi Carignan (C. Laurent). I 889-9I.

I462. Les Coutumes de Lorris (M. Prou). I 884.

1463. Boileau, Etienne. Le Livre des Métiers

(G. B. Depping, 1837; R. de Lespinasse and F. Bonnardot, I880). Soc. de l'Hist. de France.

\section{Miscellaneous.}

1464. Collection des Documents relatifs à l'histoire de l'industrie et du commerce (G. Fagniez). I 898-I 900 . 
1465. Documents monétaires (L. Caignart de Saulcy). Doc. inéd. relatifs à l'hist. de France). 1879. 1466. Documents inédits pour servir à l'histoire des institutions et de la vie privéc en Bourgogne (XIVe et XVe siècles). (J. Simonnet.) 1867.

1467. Choix de documents sur les relations de la royauté avec les villes en France (A. Giry), I1 80-1 314. 1895.

1468. Doublet, F. J. Histoire de l'Abbaye de St. Denys. 1625 .

1469. Le Ménagier de Paris (M. Pichon). Soc. des Bibliophiles Francais. 1847.

1470. Livres de raison, régistres de famille et journeaux individuels limousins et marchois (L. Guibert, etc.), I888; Nouveau Recueil de régistres, etc., 1895 .

1471. Matthews, J. Welsh Records in Paris. Carmarthen, 19 ro.

1472. Le Débat des Hérauts d'Armes de France et d'Angleterre (P. Meyer). Société des Anciens Textes Français. 1877.

1473. Nicolas Oresme. Traité des monnaies. 1854 .

1474. Paris sous Philippe le Bel (H. Géraud). Documents Inédits. 1837

1475. Journal d'un Bourgeois de Paris, 1405-49 (A. Tuetay). Société de l'histoire de Paris et de l'Ile de France. I $88 \mathrm{I}$.

1476. Teulet, J. Inventaire chronologique des documents relatifs à l'histoire d'Écosse conservés aux Archives du Royaume à Paris. Abbotsford Club, XIV. 1839.

1477. Ugo Teralh. Notaire et drapier à Forcalquier (1330-2). (Paul Meyer.) I909.

\section{LOW COUNTRIES.}

\section{Diplomatic Documents.}

1478. Cartulaire des Comtes de Hainaut (L. Devillers). Brussels, 1881-96. 


\section{I64 A SELECT BIBLIOGRAPHY OF}

I479. Duvivier, C. Actes et documents anciens intéressants la Belgique (813-XIIIe siècle). Brussels, 1898 .

I480. Gachard, L. P. Collection de documents inédits, concernant l'histoire de la Belgique. I833-35.

1481. Receuil des anciennes coutumes de la Belgique. Brussels, I 867, etc.

1482. Receuil de documents relatifs à l'Histoire de l'Industrie drapière (G. Espinas and $\mathrm{H}$. Pirenne). Commission Royale d'Histoire. Brussels, I 906-09.

1483. Reusens, E. and Barbier, J. Analectes pour servir à l'histoire ecclésiastique de la Belgique. Louvain, I864, etc.

1484. Wauters, A. Analectes de diplomatique. Commission Royale d'Histoire, sér. 4, tt. VII., VIII., X., XIII., XIV., XVII.

1485. Wauters, A. Table chronologique des chartes et diplômes imprimés concernant l'histoire de la Belgique (-1339). Brussels, I866, etc.

1486. Codex diplomaticus neerlandicus. Historisch Genootschap van Utrecht. Utrecht, I848, $1852-63$.

1487. Lijst van oorkonden betreffende Holland en Zeeland, I299-I 345 (P. L. Muller). Hague, I88I.

I488. Nijhoff, I. A. Gedenkwaardigheden uit de Geschiedenis van Gelderland, door onuitgegevene oorkonden opgehelderd. Arnhem, Hague, $1830-75$.

1489. Oorkondenboek van Groningen en Drenthe. (P. J. Blok and J. A. Feith.) Groningen, I 899 .

1490. VAN Mieris, Frans. Groot Charterboek der Graven van Holland van Zeeland en Heeren van Vriesland. Leyden, 1753-6. 
149I. Chronologisch Register op het vervolg van het Groot-Charterboek van Van Mieris. Provinciaal Utrechtsch Genootshap van Kunsten en Wettenschappen. Utrecht, 1859.

Accounts and Guilds.

1492. De oudste Stadsrekeningen van Dordrecht, I284-I 424 (C. M. Dozy). Hague, I89I.

1493. De Gilden van Utrecht tot 1528 . Utrecht. I896, etc. Vereeniging tot Uitgave der Bronnen van het Oude Vaderlandsche Recht.

1494. De Registers en Rekeningen van het Bisdom Utrecht, $1325-36$ (S. Muller). Historisch Genootschap van Utrecht, N.S., No. 53. Utrecht, I 889-9I.

1495. La Charité Saint Christophe et ses comptes du XIIIe siècle (L. Verriest). Brussels, 1904.

1496. Le Livre de l'Abbé Guillaume de Ryckel. Polyptyque et comptes de l'abbaye de St. Trond, I 249-72. (H. Pirenne). Brussels, 1896.

1497. La Preuve du Servage dans le droit coutumier de Tournai. Documents inédits, I170-1412 (L. Verriest). Brussels, 1905.

1498. Le Soulèvement de la Flandre maritime de 1323-28. Documents inédits (H. Pirenne). Brussels, 1900.

1499. Rekeningen der stad Groningen (P. J. Blok). Groningen, 1896.

\section{Judicial Proceedings.}

1500. Documents sur les moeurs populaires et le droit de vengeance dans les Pays-Bas au XVe siècle (C. Petit-Dutaillis). 1908, etc.

1501. Institutions judiciaires de Tournai au I3me siècle. Les registres de justice, 1275-76, I 279-80, and I 280-8 I (L. Verriest). Tournai, 1905. 


\section{Miscellaneous.}

I 502. Dehaisnes, C. Documents, etc., concernant l'histoire de l'art dans la Flandre, l'Artois and le Hainaut avant le XVe siècle. Lille, I 886.

I 503. Houtte, H. VAN. Documents pour servir à l'histoire des prix, de I38I à 1794. Brussels, I 902 .

I504. Utrechtsche Jaarboeken van de Vyftiende Eeuw (C. Burman). I750-54.

\section{EMPIRE (GERMANY, ETC.). Diplomatic Documents. ${ }^{1}$}

I506. Bibliotheca rerum Germanicarum (P. Jaffé). Berlin, I 864-73.

I507. Codex Diplomaticus Prussicus (J. Voigt). -I404. Konigsberg, I836-6r.

1508. Diplomata Regum et Imperatorum Germaniae. Hannover, I 879-1909. Monumenta Germaniae Historica.

I 509. Fontes rerum Bernensium. Berne, I883.

I 5 I0. Leibnitz, G. W. Scriptores rerum Brunsvicensium. Hanover, I707.

1511. Monumenta Germaniae Historica. Scriptores. Hannover, I 885, etc.

I 5 12. Monumenta Wittelsbacensia, I 204-I 397 (F. M. Wittmann). Munich, I857, r86I. In Quellen und Erörterungen zur bayerischen und deutschen Geschichte.

I 513. Regesta Habsburgica,_-I28 I (H. Steinacker). Innsbruck, I905.

I514. Regesta Imperii, 731-r378 (J. F. Böhmer). New edition by E. Mühlbacher. Innsbruck, I908.

1515. Regesten der Markgrafen von Baden und Hachberg, I050-I 5 I 5 (R. Fester). Innsbruck. I 892-I907.

\footnotetext{
${ }^{1}$ The "Urkundenbücher" besides containing charters include semi-official instruments.
} 
1516. Rymer's Foedera, Syllabus of (T. D. Hardy). 1869-85.

1517. Urkundenbuch der Landschaft Basel, 708-15 I 2. (H. Boos). Vol. I.-II. Basel, 1881-83.

15 18. Urkundenbuch der Stadt Basel (R. Wackernagel und R. Thommen). Vol. I.-IX. Basel, 1890.

1519. Urkundenbuch des Landes ob der Enns. Museum Francisco Carolinum zu Linz. Wien, $1852-83$.

1520. Dortmunder Urkundenbuch (K. Rübel). Dortmund, i 885 , etc.

1521. Urkundenbuch der Abtei St. Gallen (H. Wartmann). Vol. I.-III. Zürich, r863-82. Vol. IV., St. Gallen, 1892.

1522. Urkundenbuch der Stadt Goslar (G. Bode). Geschichtsquellen der Provinz Sachsen. Historische Commission der Provinz Sachsen. Halle, 1893.

1523. Urkundenbuch Hochstifts Halberstadt und seiner Bischöfe (G. Schmidt). Leipzig, I 883-9. Publikationen aus den $K$. preussischen Staats archiven. Vol. XVII., XXI., XXVII., XL.

1524. Urkundenbuch, Hamburgisches, 786-1300 (J. M. Lappenberg). Hamburg, 1842.

1525. Urkundenbuch des Stiftes und der Stadt Hameln, - 1407 (O. Meinardus). Hannover, 1887. Quellen und Darstellungen zur Geschichte Niedersachsens. Historischer Verein für Nicdersachsen. Vol. II., X.

1526. Urkundenbuch, Hessisches, I 300-1 359(A. Wyss). Leipzig, 1879, etc. Publikation aus den königlichen preussischen Staats-archiven.

1527. Urkundenbuch der Stadt Magdeburg (G. Hertel). Halle, 1892 - Geschichtsquellen der Provinz Sachsen. Vol. XXVI.-XXVIII.

1528. Urkundenbuch der Stadt Halberstadt (G. Schmidt). Halle, 1878. Geschichtsquellen der Provinz Sachsen. 
I 529. Urkundenbuch des Hochstifts Hildesheim und seiner Bischöfe (K. Janicke). Leipzig, 1896. Publikationen aus den K. preussischen Staatsarchiven. Vol. VI. and XI.

1530. Urkunden und Akten zur Geschichte der Verfassung und Verwaltung der Stadt Koblenz (M. Bär). Bonn, I898.

I531. Kölner Schreinsurkunden des 12 Jahrhunderts (R. Hoeniger). Bonn, i 884. Publikationen der Gesellschaft für Rheinische Geschichtskunde.

1532. Das Lütisburger Copialbuch in Stuttgart (H. Wartmann). St. Gallen, I89I. Publication des historischen Vereins in St. Gallen.

1533. Urkundenbuch nebst Regesten, Liv-Esth-und Curländisches (F. G. v. Bunge). Reval, I 852-1873.

1534. Urkundenbuch der Stadt Lübeck Codex Diplomaticus Lubecensis. Lübeck, I843.

1535. Urkundenbuch zur Geschichte der jetzt die preussischen Regierungsbezirke Coblenz und Trier bildenden Mittelrheinischen Territorien (H. Beyr). Coblenz, I860.

1536. Urkundenbuch der Stadt Quedlinburg (K. Janicke). Halle, 1873. Geschichtsquellen der Provinz Sachsen.

1537. Urkundenbuch, Pommerellisches. Westpreussischen Geschichtsverein Danzig. 1881.

1538. Urkunden Schlesischer Dörfer zur Geschichte der ländlichen Verhältnisse und der Flurantheilung insbesondere (A. Meitzen). Breslau, 1863. Codex Diplomaticus Silesiae.

1539. Urkunden und Aktenstücke, die Schlesische Oderschiff-fahrt in Vorpreussischer Zeit (K. Wutke). Vol. XVII. Codex Diplomaticus Silesiae. Breslau, I 857 -

1540. Urkundenregister, Schweizerisches, I 200 (B. Hidber). Bern, I863-77. 
1541. Urkunden zur Schweizergeschichte aus oesterreichischen Archiven (R. Thommen). 7651410. Basel, 1899-1900.

1542. Urkunden zur Geschichte von Oesterreich, Stciermark, Kärnten, Krain, Görz, 'Triest, Istrien und Tirol, 1246-1 300 (J. Chmel). Wien, 1849. Pt. 2, Fontes Rerum Austriacarum.

1543. Urkunden und Akten der Stadt Strassburg (A. Schulte and others). Strassburg, 1888, etc.

1544. Urkunden zur Verfassungsgeschichte Deutschlands im Mittelalter. (W. Altmann und E. Bernheim). Berlin, I909.

1545. Urkundenbuch, Wirtembergisches. Königlichen Staatsarchiv in Stuttgart. Stuttgart, I 849 , etc.

1546. Urkundenbuch der Stadt Worms (H. Boos). Berlin, 1886-90. In Quellen zur Geschichte der Stadt Worms.

\section{Ministerial Proceedings.}

Surveys, Extents.

1547. Liber fundationis episcopatus vratislaviensis (H. Markgraf and J. W. Schulte). Breslau, 1889. Vol. XIV., Codex Diplomaticus Silesiae.

1548. Oesterreichische Urbare. Vienna und Leipsic, 1904, etc.

1549. Rheinische Urbare (B. Hilliger and others). Bonn, 1902-1906. In Publikationen der Gesellschaft für rheinische Geschichtskunde.

1550. Urbarium Ducatus Baiuwariae Antiquissimum, etc. Vol. XXXVI., Monumenta Boica. Munich, 1852.

Accounts.

1551. Handelsrechnungen des Deutschen Ordens (Dr. C. Sattler). Leipzig, 1887. Verein für die Geschichtevon Ost und West Preussen. 
1552. Libros antiquissimos civitatis Cracoviensis, I300-I400. Cracow, I878. Vol. IV., Monumenta medii aevi historica res gestas Poloniae illustrantia.

1553. Rechnungsbücher der hamburgischen Gesandten in Avignon, I 338-1355 (Th. Schrader). Verein für Hamburgische Geschichte. Hamburg u. Leipzig, I907.

1554. Rechnungen, Der Koblenzer Mauerbau, I276I289 (M. Bär). Leipzig, I888. Publikationen der Gesellschaft für rheinische Geschichtskunde. Vol. V.

1555. Stadtrechnungen des Mittelalters, Die Kölner (R. Knipping). Bonn, 1897. XV. Publicationen der Gesellschaft für rheinische Geschichtskunde.

1556. Stadtrechnungen, Die vier ältesten bernischen (E. Welti). Archiv des historischen Vereins des Kantons Bern, Vol. XIV. Bern, I 895.

Laws.

\section{Judicial Proceedings.}

1557. Capitularia regum Francorum. I883, I897. Monumenta Germaniae Historica.

1558. Dortmunder Statuten und Urtheile. Vol. III. Hansische Geschichtsquellen. Halle, I882.

1559. Constitutiones et Acta Publica Imperatorum and Regum (L. Weiland). Hannover, I893I9I I. Monumenta Germaniae Historica.

1560. Legum Nationum Germanicarum (K. Zeumer). Hannover, 1902. Monumenta Germaniae Historica.

1561. Quellensammlung zur Geschichte der Deutschen Reichsverfassung im Mittelalter und der Neuzeit (K. Zeumer). Leipzig, 1904.

1562. Nürnberger Polizei Ordnungen aus dem XIII. bis XV. Jahrhundert (J. Baader). Stuttgart, I 86I . 


\section{MEDIEVAL ECONOMIC HISTORY I 7 I}

1563. Oestereichische Stadtrechte und Satzungen aus der Zeit der Babenberger (D. A. v. Müller). Wien, 1853. Archiv für Kunde Oesterreichischer Geschichtsquellen, Vol. X.

1564. Die Quellen des Revaler Stadtrechts (F. G. v. Bunge). Dorpat, r842-46. In Quellen des Curländischen Landrechts.

1565. Das rote Buch der Stadt Ulm (C. Mollwo). 1905. Würtembergische Geschichtsquellen, Vol. VIII.

1566. Urkundliche Beiträge zur Rechtsgeschichte ober- und niederösterreichischer Städte, Märkte und Dörfer vom 12 bis 15 Jahrhunderte (G. Winter). Innsbruck, 1877 .

1567. Grodbücher, die ältesten gross-polnischen, I 3861400. Leipzig, I887-9. (J. v. Lekszycki.) Publikationen aus den königlichen preussischen Staatsarchiven.

1568. Die Hallischen Schöffenbücher (G. Hertel). Historische Commission der Provinz Sachsen. Halle, 1882.

1569. Der Schwabenspiegel, oder schwäbisches Land und Lehen Rechtbuch nach einer Handschrift vom Jahre, I289 (F. L. A. v. Lassberg). Tübingen, 1840 .

1570. Weistümer, Gesammelt von J. Grimm. Historische Kommission bei der königlichen Akademie der Wissenschaften zu München, Vols. V., VI., VII. Göttingen, I840-3, I863-78.

1571. - Oesterreichische. Kaiserliche Akademie der Wissenschaften. Wien, 1870.

Town Origins and Gild Regulations.

1572. Quellen zur Geschichte der Stadt Köln (L. Ennen u. G. Eckertz). Köln, 1860.

1573. Stadtsbuch, Berlinisches a. d. Ende des 14 Jahrhunderts. Berlin, I883. 
I 574. Urkunden zur städtischen Verfassungsgeschichte (F. Keutgen). Berlin, 1899-1901. Ausgewälte Urkunden zur deutschen Verfassungsgeschichte.

1575. Die Strassburger Tucher und Weberzunft (G. Schmoller). Strassburg, 1879.

1576. Zunfturkunden, Die Kölner, bis zum Jahre I 500. (H. von Loesch). Bonn, 1907. Gesellschaft fïr Rheinische Geschichtskunde. Vol. II.

I 577. Zunfturkunden der Stadt Luneberg, Die älteren (E. Bodeman). Hannover, 1883. Quellen und Darstellungen zur Geschichte Niedersachsens. Vol. I.

1578. Zunftrollen und Brüderschaftsstatuten, Die ältesten Hamburger (O. Ruediger). Hamburg, I 874 .

I 579. Die ältesten Osnabrückischen Gilde-Urkunden, I 500 (F. Philippi). Osnabrück, 1890.

1580. Schlesische Urkunden zur Geschichte des Gewerberechts insbesondere des Innungswesens aus der Zeit vor 1400 (G. Korn). Breslau, i867. Vol. VIII., Codex Diplomaticus Silesiae.

I58I. Zunft und Polizei Verordnungen des I4 und I 5 Jahrhunderts, Strassburger. (J. Brucker). Strassburg, I 889.

1582. Zunftrollen, Die älteren Lübeckischen Wehrmann). Lübeck, 1864 .

The Hanse.

I583. Hanserecesse. Historische Commission bei der Königlichen Akademie der Wissenschaften, 1256-1430. Leipzig, 1870-97.

I 584. Hanseakten aus England, 1275-1412 (K.Kunze). Halle, 1891. Hansische Geschichtsquellen.

I585. Hanseatic League. II., V., XI. Reports. Historical MSS. Commission. 
1586. Lappenberg, J. M. Urkundliche Geschichte des hansischen Stahlhofes zu London. Hamburg, $185 \mathrm{I}$.

1587. Leitfaden für die Aelterleute des Deutschen Kauffmanns zu Brügge (K. Koppmann). Hamburg, 1875.

1588. Das Verfestungsbuch der Stadt Stralsund (O. Francke). Halle, 1875. Hansische Geschichtsquillen.

1589. Das Buch des Lübeckischen Vogts auf Schonen. (D. Schäfer). Halle, 1887. Hansische $G_{\ell-}$ schichtsquellen.

1590. Revaler Zollbücher und Quittungen des I4 Jahrhunderts (W. Stieda). Halle, I889. Hansische Geschichisquellen.

1591. Handlungsbuch, Johann Tölners, I $345^{-1} 350$ (K. Koppmann). Rostock, I885. Geschichtsquellen der Stadt Rostock.

1592. Das Handlungsbuch von Hermann und Johann Wittenborg (C. Mollwo). Leipzig, I90I.

1593. Das Handlungsbuch Vickos von Geldersen $(H$. Nirnheim). Hamburg, Leipzic, 1895.

1594. Simonsfeld, H. Der Fondaco dei Tedeschi in Venedig und die Deutsch-Venetianischen Handelsbeziehungen. Stuttgart, 1887.

1595. Urkundenbuch, Hansisches. Verein $f$. Hansische Geschichte. Bd. I-6, 8 u. g. Halle u. Leipzig, 1876-1905.

\section{Miscellaneous.}

I596. Deutsche Privatbriefe des Mittelalters (G. Steinhausen). Vol. I. and II. 1899 and 1907.

1597. Liliencrow, Baron R. von. Die Historischen Volkeslieder der deutschen, vom 13 bis 16 Jahrhundert, 1865 , etc. Historische Commission bei der Königl. Acad. der Wissenschaften. 


\section{THE PAPACY. \\ Diplomatic Documents.}

1598. Acta Pontificum Romanorum inedita, 97-I I 97

(J. v. Pflugk-Harttung). Tübingen, 1881I 885 .

1599. Analecta Vaticana (O. Posse). Innsbruck, 1878.

1600. Codex Diplomaticus dominii temporalis Sancti Sedis, 756-1793 (A. Theiner). Rome, I86II862.

I60I. KeHR, P. Papsturkunden in Rom.

1602. Päbstliche Urkunden und Register aus den Jahren, I 295-1352 (G. Schmidt). Halle, I886. Vol. XXI., Geschichtsquellen der Provinz Sachsen.

I603. Papsturkunden Westfalens (H. Finke). Münster, I888. Vol. V., Westfälisches Urkundenbuch.

1604. Record OfFice. Calendar of Entries in the Papal Registers relating to Great Britain and Ireland. I893, etc.

1605. Registres des Papes du XIIITe siècle. Bibliothèque des écoles françaises d'Athènes et de Rome. IIe serie. Paris. I 898.

1606. Regesta Honorii Papae III. (P. Pressutti). Rome, I 888-95.

I607. Regesta Pontificum Romanorum (to II98). (P. Jaffé), Leipzig, I 885-8.

1608. Regesta Pontificum Romanorum (II98-1304.) (Augustus Potthast). Berlin, I874-5.

I609. Regesta Pontificum Romanorum (P. F. Kehr). Berlin, 1906, etc. Königliche Gesellschaft der Wissenschaften Göttingen.

\section{Ministerial Proceedings.}

I6ro. Le Liber Censuum de l'église romaine (P. Fabre and L. Duchesne). Bibliothèque des écoles françaises d'Athènes et de Rome. 2 série 6. Paris, I889-rgro. 
1611. Registrum curiae Patrimonii Beati Petri in Tuscia. Vol. IX., Mélanges d'archéologie et d'histoire, Ecole frangaise de Rome. Paris, Rome, 1889.

1612. Auszüge aus den Rechnungsbücher der apostolischen Kammer für das Gebiet des heutigen Königreiches Wurttemberg aus den Jahren, 1396-1534. Stuttgart, 1895. Vol. II., Wurtembergische Geschichtsquellen (D) Schaefer).

1613. Die päpstlichen Kollektorien in Deutschland während des 14 Jahrhundert (J. P. Kirsch). Paderborn, 1894. Vol. III. Papst Urkunden Italiens, in Quellen und Forschungen vom $K$. Preussisch. historisch. Institut. in Rom.

1614. Untersuchungen und Urkunden über die camera collegii Cardinalium für die Zeit von 12951437. (P. M. Baumgarten.) Leipzig, 1898.

1615. Vatikanische Quellen zur Geschichte der päpstlichen Hof und Finanzverwaltung, 1316-1 378. $K$. Preussisch. historisch. Instit. in Rom. Paderborn, 1910, etc.

1616. Liber Cancellariae Apostolicae, vom Iahre 1380 (G. Erler). Leipzig, 1888.

1617. Liber Diurnus (E. de Roziére). Paris, I869. 1618. Die päpstlichen Kanzlei Ordnungen von 12001500 (M. Tangl). Innsbruck, 1894.

16r9. Regulae Cancellariae Apostolicae. Die päpstlichen Kanzlei Regeln, von Johannes XXII. bis Nicolaus V. (E. v. Ottenthal). Innsbruck, I 888 .

\section{Miscellaneous.}

1620. Goller, E. Die päpstliche Pönitentiarie etc. 1907, etc. (K. Preussisch. Historisch. Instit. in $R o m$.) 


\section{I76 A SELECT BIBLIOGRAPHY OF}

i62i. Monumenta Germaniae. Libelli de lite inter regnum et sacerdotium saeculi XI. and XII. Hanover I 890 .

i622. Liber Pontificalis (L. Duchesne). IIe Série Bibliothèque des écoles françaises d'Athènes et de Rome. Paris, 1892.

1623. Patrologiae Latinae (J. P. Migne). Paris, I $844-64$.

\section{ITALIAN STATES. \\ Diplomatic Documents.}

1624. Urkunden zur älteren Handels und Staatsgeschichte der Republik Venedig (G. L. F. Tafel and G. M. Thomas). Vienna, I 856, etc. Oesterreichische Geschichtsquellen Abt. II. Diplomataria et Acta.

1625. Calendar of the Venetian State Papers. I 860, etc. 1626. Boinhardt, J. B. Codex Traditionum ecclesiæ Ravennatensis. Munich, I810.

1627. Muratori, T. A. Rerum Italicarum scriptores, Vols. I-XII. Milan, I723-I75I.

1628. TAFEL, G. L. Fr., und Thomas, G. M. Urkunden zur älteren Handels-u-Staatsgeschichte der Republik Venedig (9-I 5c.). Fontes rerum Austriacarum. Diplomataria et Acta XII.XIV.

\section{Miscellaneous.}

i629. Balzani, U. Un' Ambasciata inglese a Roma, 1487. Roma, Livorno, 1879.

1630. Le Cronache italiane nel medio evo. Milan, 1909.

1631. Corneto, Statuto dell arte del ortolani. (Fonti de Storia Cornetana. (F. Guerri). CornetoTarquinea, 1908, etc.

1632. I Capitolari delle Arti Veneziane (G. Monticolo). 1896, etc. Instit. Storico Italiano Fonti par la storia d' Italia, No. 26. 
1633. La Sorsa, S. L'Organizzazione dei Cambiatori Fiorentini. Cerignola, 1903.

1634. Ptasnik, J. Italia mercatoria apud Polonos saeculo XV. ineunte. Rome, I9ro.

1635. Sanuto, M. I diarii di Marino Sanuto. Venice, I879-190I.

\section{THE PENINSULAR KINGDOMS.}

Spain. Diplomatic Documents.

1636. Actas de las Cortes de Castilla. Madrid, I877, etc.

1637. Coleccion de cedulas, cartas, patentes, etc., concernientes á las provincias vascongadas. Madrid, 1829-1830.

1638. Coleccion de privilegios, etc., concedidos á varios pueblos y corporaciones . . . de Castilla. Madrid, I830-33.

1639. Coleccion de documentos inéditos para la historia de Navarra. Pamplona, I900.

1640. Coleccion de documentos inéditos del Archivo general . . de Aragon. Barcelona, 1847-1 876 .

1641. Coleccion de los tratados, etc., con los estados estranjeros desde el yeinada de Doña Isabel II. Madrid, 1890-92.

1642. Coleccion de documentos inéditos para la historia de España. Madrid, I842-1895.

1643. Nueva coleccion de documentos, etc. Madrid, $1892-1896$.

1644. Monumentos historicos de Valencia. Valencia, I895, etc.

1645. Privilegios, etc., de Mallorca desde Siglo XIII. Palma de Mallocca, 1895-6.

1646. Ballester y Castell, R. Las Fuentas narrativas de la historia de España durante la edad media, 417-1474. Palma de Mallorca, 1908. 1647. Schwatz y Lana, F. Coleccion de documentos, etc., de Barcelona. Barcelona, I895, etc. 


\section{Portugal.}

1648. Collecção de livros ineditos de Historia Portugueza. Lisbon, I790-1824.

I649. Portugaliae Monumenta Historica. Lisbon, I856, etc.

1650. Quadro elementar das relaciones politicas e diplomaticas de Portugal. Lisbon, 1842I 860.

I65I. Barros, H. da Gama. Historia da administração publica em Portugal. Lisbon, 18851896.

\section{THE SCANDINAVIAN KINGDOMS.}

Denmark.

\section{Diplomatic Documents.}

1652. Acta Pontificum Danica, 1316-1536

(A.

Krarup and J. Lindbalk). Copenhagen, 1907.

1653. Diplomatarium Vibergense, I 200-I 559 (C. A. L. Heise). Copenhagen, I879. Kongel. Dansk Selskab til den Nordiske Histories og Sprogs Forbedring.

1654. Dueholms Diplomatarium, I37I-I539 (O. Nielsen). Copenhagen, 1872. Kongel. Dansk Selskab til den N. Histories Forbedring. 1655. Kjøbenhavns Diplomatarium (O. Nielsen). Copenhagen, I 872-87.

1656. Regesta Diplomatica Historiae Danicae. Series I. and II. Copenhagen, I847-70, and I8891907.

1657. Repertorium Diplomaticum Regni Danici Mediaevalis (K. Erslev and W. Christenson). Copenhagen, 1894, etc. Selskab f. Udgivelse af Kilder til Dansk Historie.

Norway.

1658. Regesta Norvegica (G. Storm), 99I-1263. Christiania, 1898. Norsk Historisk Kildeskriftfond. 
1659. Diplomatarium Norvegicum (C. C. A. Lange and C. R. Unger). Christiania, I849, etc.

See especially the series of English entries collected by Prof. Bugge.

1660. Registrum Ecclesiae Abocnsis (R. Hausen). Helsingfors, 1890.

\section{Sweden.}

1661. Svenska stadsprivilegier. Upsala, 1907, etc.

1662. Urkunder til Stockholms historia (C. Hildebrand). Upsala, 1900, etc. Humanistiska Vetenskaps-samfundet.

1663. Svenskt Diplomatarium (J. G. Liljegren). Stockholm, 1829 , etc.

\section{Miscellaneous.}

1664. Antiquitates Americanae sive Scriptores Septentrionales rerum ante-Columbianarum in America. Copenhagen, 1837. Societas Regia Antiquariorum Septentrionalium.

1665. Fru Eline Gøyes Jordebog (A. Thiset). Copenhagen, 1892. Kongeligt Dansk Selskab for Faedrelandets Historie og Sprog.

1666. Aslak Bolt's Jordebog (P. A. Munch). Christiania, 1852.

1667. Stockholms Stads Jordebok, 1420-74 (H. O. H. Hildebrand). Stockholm, 1876-89. Kongl. Samfundet för uitgifvande af handskrifter rörande Skandinaviens historia.

1668. Logbok Islendinga nefnist Gragas : Codex Juris Islandorum antiquissimus qui nominatur Gragas (J. F. G. Schlegel). Copenhagen, 1829. 1669. Corpus Juris Sueo-Gotorum (H. S. Collin and C. J. Schlyter). Stockholm, 1827-77.

1670. Registrum praediorum et redituum ad ecclesias diocesis Bergensis sacculo XIV pertinentium : Bergens Kalvskind (P. A. Munch). Christiania, 1843 . 
I671. Meddelelser fra Rentekammerarchivet, inholdende Bidrag til Danmarks Historie (J. Grundtvig). Copenhagen, I87I-78.

1672. Liber Census Daniae. Kong Valdemar IIs Jordebog (O. Nielsen). I873.

1673. Afgifter fra den Norske Kirkeprovins till det Apostolike Kammer, I3II-I523 (G. Storm). Christiania, I897.

1674. Pavelige Nuntiers Regnskabs og Dagböger, I 282-I334 (P. A. Munch). Christiania, I 864. 1675. Silffererstolpe, C. Historiskt Bibliothek. Stockholm, 1875, etc.

1676. Scriptores Rerum Suecicarum Medii Aevi (C. Annerstedt and E. M. Fant). Upsala, I 81 8-76.

1677. Saxo Grammaticus. The first Nine Books of the Danish History of Saxo Grammaticus (trans. by O. Elton). I 894 .

1678. Scriptores rerum Danicarum medii aevi. (J. Langebeck and P. F. Suhm.) Copenhagen, I $772-1834$.

I679. Schive, C. I. Norges Mynter i Middelalderen. Christiania, I860.

1680. Bidrag til Finlands Historia (R. T. Hausen). Helsingfors, I 88I-83.

I68I. Weibult, L. Bibliotek och arkiv i Skåne under medeltiden. Lund, I90I.

1682. Origines Islandicae (G. Vigfusson and F. York Powell). I905.

1683. Corpus Poeticum Boreale (G. Vigfusson and F. York Powell). 1883.

1684. Icelandic Sagas (G. Vigfusson and G. W. Dasent). Rolls Series. I887-94.

1685. Norges gamle Love (G. Storm, R. Keyser, and P. A. Munch). Christiania, I846, etc. 


\section{PART III.-MODERN Works.}

\section{Section I.-Special Periods.}

\section{A.-BEFORE THE NORMAN CONQUEST.}

1686. Adams, G. B. Anglo-Saxon Feudalism. American Historical Review, Vol. VII. I90I. 1687. Allen, Grant. Anglo-Saxon Britain. I90I. 1688. Arbois de Jubainville, H. D'. Les Celtes depuis les temps les plus anciens jusqu'en l'an 100 avant notre ère. Paris, I904.

\section{Great Britain, 3me, $4 \mathrm{me}$, and $5 \mathrm{me}$ leçons (pp. 17-46).}

1689. La Civilisation des Celtes et celle de l'épopée Homérique. Cours de Littérature Celtique. T. VI. Paris, 1899.

1690. Chadwick, H. M. The Origin of the English Nation. Cambridge, 1907.

1691. - Studies on Anglo-Saxon Institutions. 1905.

1692. Collingwood, W. G. Scandinavian Britain. 1908.

1693. Conybeare, J. W. E. Roman Britain. I9II. 1694. Coоте, H. C. The Romans of Britain. I 878. I695. Du Chaillu, P. B. The Viking Age. I 889. 1696. Elton, C. J. Origins of English History. 1890. 1697. Freeman, E. A. Teutonic Conquest in Gaul and Britain. Four Oxford Lectures, 1887.

I698. Goмme, G. L. The Village Community. With special reference to the origin and form of its survival in Britain. 1890 .

I699. GREEN, J. R. The Conquest of England. I 899. I700. The Making of England. I 897.

1701. Guest, E. Early English Settlements in South Britain. 1850 .

1702. - Origines Celticae. I883. 
I703. Haverfield, F. J. The Romanization of Roman Britain. Proceedings of the British Academy, Vol. II. 1905.

See also his important contributions to the Eng. Hist. Reviero and Victoria County Histories for this period.

1704. Hodgkin, T. Political History of England, Vol. I, from the earliest times to the Norman Conquest. 1906.

1705. Holmes, T. R. E. Ancient Britain and the invasions of Cæsar. Oxford, 1907.

1706. Horsley, J. Britannia Romana: or the Roman Antiquities of Britain. 1732.

1707. Hubner, Emil. Römische Herrschaft in Westeuropa. Berlin, I89o.

I708. Keary, C. F. The Vikings in Western Christendom. I89I.

1709. Kemble, J. M. The Saxons in England. 1876.

I7Io. Lappenberg, J. M. A History of England under the Anglo-Saxon Kings (transl. B. Thorpe). Revised ed., I 88I.

I7II. Manfrin, P. La Dominazione romana nella Gran Bretagna. Rome, I904.

I712. MARQUARDT, J. Römische Staatsverwaltung. Leipzig. Handbuch der Römischen Alterthümer, B. 4-6. I 88I-5.

i7I3. Mommsen, T. The Provinces of the Roman Empire from Cæsar to Diocletian (trans. from fifth vol. of Mommsen's Roman History, ed. I 885 , by W. P. Dickson). 1909.

1714. Oman, C. England before the Norman Conquest. I9ro.

1715. Partington, S. W. The Danes in Lancashire. 1909.

I716. Pearson, C. H. History of England during the Early and Middle Ages. I 867.

1717. Plummer, C. The Life and Times of Alfred the Great. Oxford, 1902. 
1718. RAmsay, SIR J. H. The Foundations of England (B.C. 55-A.D. II 54.) 1898.

1719. RuYs, J. Celtic Britain. 1904.

1720. SKENE, W. F. Celtic Scotland. Edinburgh, 1886-1 890.

1721. SPECK, E. Handelsgeschichte des Altertums. Leipzig, 1900-1906.

1722. Stennstrup, J. C. H. R. Normannerne. Copenhagen, 1 876-82.

1723. Streatreild, G. S. Lincolnshire and the Danes. 1884 .

1724. Stubis, W. Lectures on early English history 1906.

1725. VAlroger, L. DE. Les Celtes. La Gaule Celtique. Paris, I 879.

1726. WARD, J. The Roman Era in Britain. I9II. 1727. Worsaae, J. J. A. An Account of the Danes and Norwegians in England, Scotland, and Ireland. (Trans.) 1852.

\section{B.-FROM 1066 TO 1485.}

1728. Adams, G. B. The history of England. 1905. Political History of England (ed. Hunt and Poole), Vol. II. (See No. 1758.)

1729. Armitage-Smith, S. John of Gaunt, I 340-1 399. 1904 .

1730. Beaurepaire, R. DE. Les états de Normandie sous la domination anglaise. I859.

1731. Boutaric, E. La France sous Philippe le Bel. I86I.

1732. Brissaud, D. Les anglais en Guienne. 1865.

1733. BurckHARDT, J. Die Kultur der Renaissance in Italien. Leipzig, 1908.

1734. Clayton, J. True story of Jack Cade, A.D. I450. 1909.

1735. Davis, H. W. C. England under the Normans and Angevins. 1909. (Oman, C. W. C., $A$. History of England, Vol. II., 1904, etc.) 
1736. Denton, W. England in the fifteenth century. I 888.

1737. Dunn Patrison, R. P. The Black Prince. 1910.

1738. Eyton, R. W. Court, household, and itinerary of King Henry II. 1878.

1739. Freeman, E. A. The history of the Norman Conquest of England: Its causes and results. Oxford, I 867-79.

1740. The reign of William Rufus and the accession of Henry I. Oxford, I802.

174I. Gairdner, J. Lollardy and the Reformation in England. 1908.

1742. - Henry III. and the Church. 1905.

1743. Hardy, B. C. Philippa of Hainault and her times. I9IO.

1744. Hill, G. Some consequences of the Norman invasion. 1904 .

1745. KосH, H. Richard von Cornwall, I209-1287. Strasburg, I 888.

1746. Luce, S. La France pendant la guerre de Cent Ans. I 889.

1747. McKechnie, W. S. Magna Carta: A Commentary on the Great Charter . . . with an Historical Introduction. 1905.

1748. Mackinnon, J. History of Edward III. 1900.

1749. Maitland, F. W. Domesday Book and Beyond. Cambridge, I897.

1750. Markham, C. R. Richard III. 1906.

1751. Norgate, K. England under the Angevin kings. 1887 .

I752. Oman, C. W. C. The great revolt of 1381 . 1906.

1753. Orpen, G. H. Ireland under the Normans, I169-1216. Oxford, I911.

1754. Pearson, C. H. English History in the Fourteenth Century. 1876.

1755. Round, J. H. Feudal England: Historical Studies of the I 2 th and 13 th centuries. 1892.3 


\section{MEDIXVAL ECONOMIC HISTORY $\quad \mathbf{8 5}$}

1756. Round, J. H. Geoffrey de Mandeville: A Study of the Anarchy. 1895.

1757. StratFord, L. Edward IV. (Makers of National History). 1910.

1758. Tout, T. F., The Political History of England, I216-1377. $1905-7$.

1759. Trevelyan, G. M. The Peasant's Rising and the Lollards. 1899.

See No. 2568.

1760. England in the Age of Wycliffe. 1909.

1761. Vickrers, K. H. Humphrey, Duke of Gloucester. 1907.

1762. WyLIE, J. H. History of Engiand under Henry IV. 1888 , etc. 


\section{Section II.-Special Subjects.}

\section{A.-CENTRAL GOVERNMENT.}

\section{(a) The Crown.}

Court and Household.

1763. Baillie-Grohman, W. A. and F. The Master of Game, 1406. 1904.

1764. Bateson, M. The Scottish King's Household. furidical Review. Edinburgh, I901.

1765. Bond, E. A. Notices of the last days of Isabella, Queen of Edward II., drawn from an account of the expenses of her household. Archaologia XXXV. I853.

1766. Bray, W. Purveyor to the King's Household : An account of the obsolete office of. Archaologia VIII., 329-362. I787.

1767. Burrows, M. The Family of Brocas of Beaurepaire. I 886.

1768. Claims at the Coronations of several of the Kings of England, beginning with Richard II. : Collections relative to. 1838 .

1769. Dibben, L. B. Secretaries in the Thirteenth and Fourteenth Centuries. English Historical Review, XXV. I9Io.

I770. Eyton, R. W. Court, household, and itinerary of King Henry II. 1878.

I77I. Furnival, F. J. Life Records of Chaucer. II. 1876.

1772. Guillois, A. Recherches sur les maitres des requêtes de l'hôtel, des origines à 1350.1909.

1773. Hall, H. Court Life under the Plantagenets. 1890.

1774. HARDY, T. D. Itinerarium Johannis Regis Angliae. Archaologia XXII., I24. 
1775. Hardy, T. D. The visits of Henry III. to the Northern Counties of England, as shown by an itinerary compiled by T. D. Hardy. Arch. Fourn. XV., 99.

1776. Hartshorne, Ch. H. The Itinerary of King Edward II. P.P. I86I.

1777. Lafontaine, H. C. DE. The King's Musick: A transcript of records relating to music and musicians, 1460-1700. 1909.

1778. Larson, L. M. The King's Household in England before the Norman Conquest. 1904.

1779. Morice, B. Marshalsea of the King's House : An essay towards the history of the Ancient Jurisdiction of the. Law Tracts, 1801-1 2, No. 8. 1780. Ordinances (Collection of) . . . for the Government of the Royal Household [Ed. III. to William and Mary]. Soc. of Antiquaries of London. 1790.

1781. Palgrave, Sir F. Merchant and Friar. 1844. 1782. Palmer, C. F. R. The King's Confessors, I256$145^{\circ}$ Antiquary, XXII., I14-20, 159-61, 262-6; XXIII., 24-26. I890-91.

1783. PegGe, S. Curialia Miscellanea. 1818.

1784. Picard, E. L'Ecuric de Philippe le Hardi. 1906.

1785. Round, J. H. The Commune of London. 1899. 1786. - The Officers of Edward the Confessor. Eng. Hist. Rev., XIX. 1904.

1787. - The King's Sergeants and Officers of State. I9II.

1788. Russel, C. E. Swallowfield and its owners. I90I.

1789. TAYLOR, A. Regality, The glory of. 1820.

1790. Тномs, W. J. The Book of the Court. 1844. 1791. Valin, L. Le duc de Normandie et sa cour, 912-1204. 1910.

1792. Wollaston, G. W. Coronation Claims. 1910. 
The Chancery and Wardrobe.

1793. Fleta (ed. Selden, II., c. 14). 1647.

1794. Langlois, $\mathrm{C}_{\mathrm{H}}$ V. La chancellerie royale depuis l'avènement de Saint Louis jusqu' à celui de Philippe de Valois. Mémoire couronné par l'Académie des Inscriptions en 1895 .

1795. Morel, O. La chancellerie royale au XIVe siècle. 1899 .

1796. Riemsdijk, T. van. De Tresorie en Kanselarij van de Graven van Holland en Zeeland uit het Henegouwsche en Beyersche Huis. Hague, 1908.

1797. Stapleton, T. A brief study of the Wardrobe Accounts of the Ioth, IIth, and I 4 th years of Edward II. Archaologia, XXVI. 1836.

1798. Topнaм, J. Liber quotidianus contrarotulatoris garderobae, $28 \mathrm{Edw}$. I. Society of Antiquaries. 1787 .

References to king's journeys; pp. lxvii., king's progress in 28 th year.

1799. Tout, T. F. The chief officers of the King's Wardrobe down to I399. English Historical Review, XXIV. I909.

The Mint.

I800. Ansell, G. F. The Royal Mint. 1870.

I801. Babelon, E. La Théorie Féodale de la monnaie. 1908.

1802. LANDRY, A. Essai economique sur les mutations des monnaies dans l'ancienne France; de Philippe le Bel à Charles VII. I9ro.

I803. Rawlings, G. B. The Story of the British Coinage. $\mathbf{1} 898$.

1804. Royal Mint, Report of Commissioners appointed to inquire into the constitution, etc., of the. Parliamentary Papers, Vol. XXVIII. 1849.

1805. Ruding, R. Annals of the Coinage of Great Britain. 1840 . 
1806. Wailly, N. DE. Des variations de la livre to urnois depuis saint Louis jusqu' à l'établissment de la monnaie décimale. 1857.

Works.

1807. Bayley, J. The History and Antiquities of the Tower of London. 1830.

1808. Lethaby, W. R. Westminster Abbey and the King's Craftsmen. 1906.

1809. Tighe, R. R., and Davis, J. E. Annals of Windsor. 1858 .

(iii) Army and Nary.

1810. Ballard, A. Castle Guard and Barons' Houses. English Historical Revicw. October, I9IO.

i8II. Boucher de Molandon, R., and Beaucorps, A. DE. L'armée anglaise vaincue par Jeanne d'Arc sous les murs d'Orleans. 1892.

1812. Boutaric, E. Institutions militaires de la France avant les armées permanentes. 1863. 1813. Clapham, J. H. The Horsing of the Danes. English Historical Review. April, 1910.

1814. Clowes, Sir W. L. The Royal Navy. A History from the Earliest Times. 1897, etc.

1815. Delpech. La Tactique militaire du XIIIe siècle. Paris, $\mathbf{1} 886$.

1816. Denifle, H. La Désolation des Eglises, monastères et Hôpitaux en France pendant la guerre de cent ans. 1897 .

1817. Dufourmantelle. La marine militaire au début de la guerre de cent ans. 1878 .

1818. - La marine française sous Philippe le Bel. 1880.

1819. Fortescue, J. W. British Army, A history of the. Vol. I., I713. 1910.

1820. FREVille, E. DE. Les grandes compagnies au XIVe siècle. Bibl. de l'Ecole des Chartes. 1842 . 
I82 I. Fulton, T. W. The Sovereignty of the Seas. I9II.

I822. George, H. B., and Morris, J. E. The Archers at Crecy. Eng. Hist. Review, X., XII. I895, I 897.

I823. Grose, F. Military Antiquities. I8I2. I824. Hannay, D. History of the Navy. Vol. I. 1898. 1825. Holmes, Sir G. Ancient and Modern Ships. Board of Education, South Kensington, Victoria and Albert Museum. I906.

I826. JAL, A. Archéologie navale. Paris, I839.

I827. Jourdain, $\mathrm{C}_{\mathrm{H}}$. Mémoire sur les commencements de la marine militaire sous Philippe le Bel. Ac. des inscriptions, Mémoires, XXX.

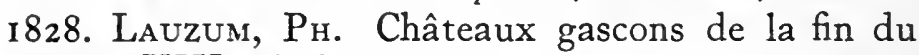
XIIIe siècle. I 897 .

1829. MARsden, R. G. Select Pleas in the Court of Admiralty (Preface). Selden Society. I894-7. I830. Morris, J. E. The Welsh Wars of Edward I. I 90 I.

1831. Nicolas, N. H. A history of the Royal Navy, (from the earliest times to 1422). 1847.

1832. OMAN, C. A history of the Art of War (from the $4^{\text {th }}$ to the I 4 th century). I 898 .

1833. Oppenheim, M. Naval Accounts and Inventories of the reign of Henry VII., I485-8 and 1495-7. (Introduction.) Navy Records Society. 1896.

I 834. History of the Administration of the Royal Navy, I 509-1660. 1896.

Intro., pp. 1-44, The Navy before I 509.

I 835. Payne-Gallwey, Sir R. The Crossbow. Projectile-throwing Engines of the Ancients. 1907.

i 836. Palliser, F. B. Historic Devices, Badges, and War Cries. I870.

I837. Sargeaunt, B. E. Weapons other than firearms. 1908. 
1838. Semerau, A. Die Condottieri. Jena, igog.

1839. Smitu, L. T. Expeditions to Prussia and the Holy Land, made by Henry, Earl of Derby. (Introduction.) Camden Soc. 1894. German edition by H. G. Prutz: Rechnungen über Heinrich von Derbys Preussenfahrten. Leipzig, I 893.

I840. Terrier De Loray, Jean de Vienne, amiral de France. Paris, 1878.

I841. Twiss, SIR T. The Black Book of the Admiralty. (Preface.) Rolls Series. 1871.

1842. Wylie, J. H. The Agincourt Roll . Trans. of the Royal Hist. Soc., 3rd series. Vol. V. 1911.

(b) Council and Parliament.

1843. Anson, W. R. Law and Custom of the Constitution. Vol. I., Parliament, 1909; Vol. II., Crown, 1908.

1844. Aucoc, L. Le Conseil d'Etat avant et depuis, 1789. 1876.

I845. BALDwiN, J. F. The Beginnings of the King's Council. Transactions Royal Hist. Soc., Vol. XIX. 1905.

1846. The Beginnings of the King's Council. Transactions Royal Hist. Soc. 1904.

1847. Early Records of the King's Council. American Hist. Revicw, XI. New York, 1905.

1848. Antiquities of the King's Council. Eng. Hist. Review. 1906.

1849. The Privy Council of the time of Richard II. American Hist. Review, XII. New York, 1906.

1850. The King's Council from Edward I. to Edward III. Eng. Hist. Review. 1908.

1851. - The King's Council and the Chancery. I. and II. American Hist. Revicw, XV. New York, 1910. 
1852. Boutmy, Emile. La Formation du parlement en Angleterre. Revue des Deux Mondes, LXVIII., 82-126. Paris, 1885.

1853. Caesar, Sir Julius. The Ancient State, Authoritie and Proceedings of the Court of Requests, etc. 1597.

1854. Desjardins, A. Etats généraux, 1350-1614. I87I.

1855. Dicey, A. V. The Privy Council. I 887.

1856. Freeman, E. A. The House of Lords, 425-502. Historical Essays. Fourth Series. 1892.

1857. Gneist, R. von. History of the English Parliament (trans. R. J. Shee). [1886]. I 895.

I858. Hervieu, H. Recherches sur les premiers états généraux et les assemblées répresentatives pendant la première partie du XIVe siècle. 1879.

I 859. Lords, House of. I.-Its Origin, by G. L. Gomme. II.-Its Functions, by J. Gairdner. III.-Its place of meeting, by $\mathrm{H}$. B. Wheatly. IV.-Transition from tenure to writ, by J. H. Round. Antiquary, Vols. IX.-XI., passim. 1884-5.

I 860. LuçAY, DE. Des Origines du pouvoir ministériel en France. I 88I.

I86r. Maitland, F. W. Records of the Parliament at Westminster in 1305. (Introduction.) Rolls Series. 1893.

1862. Nicolas, N. H. Proceedings and Ordinances of the Privy Council. (Introduction.) Record Commission. $1834-7$.

1863. Palgrave, F. An essay upon the original authority of the King's Council. Record Commission. 1834 .

1864. Petyt, William. Jus Parliamentarium. I739. I865. Piсот, G. Histoire des états généraux, I35516r4. 1872 . 
I866. Pike, L. O. Constitutional History of the House of Lords. 1894.

1867. Reiss, L. Geschichte des Wahlrechts zum englischen Parlament im Mittelalter. 1885.

1868. Schenk. Traité du ministère public. 1813.

1869. Scofield, C. L. History of the Court of Star Chamber. 1900.

1870. SkeEl, C. A. J. The Council in the Marches of Wales. 1904.

1871. Thomas, A. Les états généraux sous Charles VII. 1878.

1872. Les états provinciaux de la France centrale sous Charles VII. 1879.

\section{(c) The Law Courts.}

1873. Anglo-American Legal History, Select essays in (by various authors). American Law Schools Association. Boston, 1907-9.

1874. Adams, H. The Anglo-Saxon Courts of Law : Essays in Anglo-Saxon Law (by various writers). Boston, 1876 .

1875. Adkin, B. W. Copyhold and other Land Tenures of England. I9I I.

1876. Bateson, M. The Laws of Breteuil. Eng. Hist. Review, Vols. XV. and XVI. 1900 and $190 \mathrm{I}$.

1877. Bigelow, M. M. History of Procedure in England from the Norman Conquest. The Norman period, I066-1 204. I 880.

1878. Brunner, H. Das Anglo-normannische Erbfolgesystem. Leipzig, I 869.

1879. Die Entstehung der Schwurgerichte. Berlin, 1871 .

1880. - Geschichte der englischen Rechtsquellen im Grundriss. Leipzig, 1909.

I88I. Cox, J. C. The Sanctuaries and Sanctuary Seekcrs of Mediæval England. I9II.

1882. Ducketr, Sir G. F. The Marches of Wales. Archaologia Cambrensis, Vol. XII. I88I. 
I883. Dundas, J. A summary view of the Feudal Law, with the Differences of the Scots Law from it. Edinburgh, I 7 Io.

I884. Fournier, P. Les officialités au moyen âge, étude sur l'organisation, la compétence et la procédure des tribunaux ecclésiastiques ordinaires en France, de I I 80 à I 328. I 880.

I885. Giraud, C. Essai sur l'histoire du droit français au moyen âge. 1846 .

I 886. Gross, C. The Court of Piepowder. Quarterly Journ. of Economics, Vol. XX., pp. 231-249. I906.

1887. The Exchequer of the Jews of England in the Middle Ages. I 887.

I888. Hazeltine, H. D. Die Geschichte des Englischen Pfandrechts. Breslau, I907.

I889. Henderson, E. Verbrechen und Strafen in England, I 066-I 307. Berlin, I 890.

I 89o. Holdsworth, W. S. History of English Law. I903, etc.

I 89I. Hudson, W. Leet Jurisdiction in the City of Norwich during the I 3 th and I 4 th centuries. (Introduction.) Selden Society, Vol. V. 1892. 1892. Inderwick, F. A. The King's Peace. Social England Series. 1895.

1893. Innes, C. Lectures on Scotch Legal Antiquities. Edinburgh, I872.

I 894. Ives, G. C. Penal methods of the Middle Ages. Edinburgh, p.p. Igro.

I 895. Jones, D. Brynmor. The Study of the Welsh Laws. Articles in Cymru Fyd. I889.

I896. - The Criminal Law of Mediæval Wales. South Wales University College Magazine. I 890. 1897. KerLy, D. M. An Historical Sketch of the Equitable Jurisdiction of the Court of Chancery. Cambridge, I89o.

I898. LeA, H. C. Superstition and Force. Philadelphia, I 892 . 
1899. Leadam, I. S. Select Cases before the King's Council in the Star Chamber. Vol. I., A.D. 1477-1 509. (Introduction.) Selden Society. 1903.

1900. Lewis, Judge David. 'The Court of the President and Council of Wales, and the Marches from 1478 to 1575 (edited and annotated by Egerton Phillimore). $\quad$. Cymmrodor, XII., p. 1. 1897 .

1901. Liebermann, F. Ueber die Leges Edwardi Confessoris. Halle, I 896.

1902. -Ueber Pseudo-Cnuts Constitutiones de Foresta. Halle, 1894 .

1903. -Ueber die Leges Anglorum saeculo XIII. ineunte Londoniis collectae. Halle, 1894.

1904. Lodge, H. C. Essays in Anglo-Saxon Land Law. Boston, 1876.

1905. Lorsel, S. Essai sur la législation économique des Carolingiens d'après les capitulaires. Caen, I904.

1906. Maitland, F. W. Roman Canon Law in the Church of England. I 908.

See also Bishop Stubbs's "Oxford Lectures" (Nos. XIII. and XIV.). 1900.

1907. Manwood, John. A Treatise and Discourse of the Laws of the Forest. I 598.

1908. Marsden, R. G. Early Prize Jurisdiction and Prize Law in England. Eng. Hist. Review, 1909. Selden Society. I 892.

See also his Select Pleas in the Court of Admiralty.

1909. Matrhews, J. B. The Law of Money-lending, Past and Present. 1906.

1910. Mitchell, W. Early History of the Law Merchant. 1904.

1911. Moore, S. A., and Moore, H. S. The History and Law of Fisheries. 1903.

1912. Moore, S. A. A History of the Foreshore (with Hale's De Jure Maris and Hall's Essay on the Rights of the Crown in the Sea-shore). 1888. 
1913. Morris, W. A. The Frankpledge System. 1910.

I914. Neilson, G. Trial by Combat. 1890.

1915. Nicolson, W. Leges Marchiarum. 1747.

1916. Nys, E. Pages de l'histoire du droit en Angleterre. I9IO.

1917. Paquet, J. Lois forestières de la France. 1753.

1918. Patetta, F. Le Ordalie. Turin, I890.

igrg. Pease, J. G., and $\mathrm{C}_{\text {itt }}, \mathrm{H}$. A Treatise on the Law of Markets and Fairs. I899.

1920. Phillimore, Sir R. The Ecclesiastical Law of the Church of England. I895.

1921. Pike, L. O. History of Crime in England. I 873-6.

1922. Plummer, C. Fortescue's Governance of England. I885.

1923. Pollock, Sir F. The Land Laws. 1896.

1924. -and Maitland, F. W. History of English Law before the time of Edward I. I 898 .

1925. PrICE, G. Treatise on the Law of the Exchequer, explaining the Practice of the Court, etc. London, 1830.

1926. Putnam, B. H. The Enforcement of the Statutes of Labourers, r349-1359. Columbia University Studies. 1908.

See Introduction and $c f$. her essay on the subject in E.H.R. July, 1906.

1927. Reville, A. L'abjuratio regni : histoire d'une institution anglaise. Revue Historique, L., I-42. Paris, 1892.

1928. Robinson, T. The Common Law of Kent. 1897.

1929. Schmid, R. Die Gesetze der Angelsachsen. Leipzig, I 858.

1930. Scrutton, T. E. Land in Fetters. Cambridge, 1886.

1931. Commons and Common Fields, or the History of the Laws relating to Commons. Cambridge, 1887 . 
1932. Spence, George. The Equitable Jurisdiction of the Court of Chancery. 1846-49.

1933. Stephens, J. E. R. The Origin and Growth of Trial by Jury in England. Westminster Rev., CXLIV., 70-79. 1895 .

1934. TARdif, A. Le droit privé au XIIle siècle d'après les coûtumes de Toulouse et de Montpellier. Recueil de textes de l'histoire du Droit. 1886.

1935. Thayer, J. B. A preliminary Treatise on Evidence at the Common Law. 1898.

1936. Tномаs, F. S. The Ancient Exchequer of England. 1848.

1937. TURNER, C. J. R. A History of Vagrants and Vagrancy. 1887.

1938. Vinogradoff, P. G. Roman Law in Mediæval Europe. 1909.

1939. Viollet, P. Histoire du droit civil français. 1905.

1940. Warnkoenig, L. A., and Stein, L. Französische Staats-und Rechtsgeschichte. 1875 .

1941. Zinkeisen, F. The Anglo-Saxon Courts of Law. Political Science Quarterly, X., I32-144. Boston, r 895 .

\section{(d) The Revenue.}

Space does not permit of the inclusion of more than a few specimens of the numerous monographs on local taxation published by various archæological societies, such as the papers in the Devonshire Association Transactions, by the Rev. O. J. Reichel and the late Rev. T. W. Whale, or in the Journals of the Norwich and Sussex Archrological Societies by the Rev. W. Hudson.

1942. Archbold, W. A. J. The Somerset Religious Houses. Cambridge, 1892.

1943. Atron, H., and Holland, H. H. The King's Customs. 1908-10. 
1944. Baldwin, J. F. The Scutage and Knight Service in England. Chicago, I 897 .

1945. Baring, F. H. Domesday Tables. I909. For other works on Domesday, see below Nos.

I946. BIRD, S. R. The Scutage and Marshal's rolls. Genealogist (N.S.), No. I. I 884.

1947. Clamageran, J. J. Histoire de l'impôt en France. $1867-76$.

1948. Cox, J. C. Derbyshire in 1327-8. (Preface.) Journal of Derbyshire Archeological and Natural History Society. 1908.

1949. Crump, C. G., and Hughes, A. The English Currency under Edward I. The Debasement of the Coinage under Edward III. Economic Fournal, V., 50-67; VII., I 85-98. 1895-97.

1950. Cunningham, T. The History of the Customs, Aids, Subsidies, National Debts and Taxes of England from William the Conqueror to the present year, I778. I778.

1951. DAнn, F. Zum merowingischen Finanzrecht (Germanistische Abhandlungen zum LXX. geburtstag Konrad von Maurers). Göttingen, I893.

1952. Dómesday Studies (ed. by P. E. Dove). I 888-9I. 1953. Dowell, J. A History of Taxation and Taxes in England. I 888.

1954. EBengreuth, A. Luschin v. Allgemeine Münzkunde und Geldgeschichte des Mittelalters und der neueren Zeit. Handbuch der mittelalterlichen und neueren Geschichte. München, Berlin, I904.

1955. Espinas, G. Les finances de la commune de Douai, des origines au XV. siècle. Paris, I902. 1956. Fletcher, W. G. D. The Shropshire Lay Subsidy Roll of I Edw. III., 1327. Shropshire Arch. and Nat. Hist. Soc. Trans., 2nd ser., I., IV., V., VIII., X., XI. ; 3rd ser., V., VI., VII. Shrewsbury, Oswestry, I889-1907. 
1957. Friedlein, G. Die Zahlzeichen und das elementar Rechnen der Griechen und Römer, und des Christlichen Abendlandes, vom 7 bis 13 Jahrhundert. Erlangen, 1869.

1958. Fuller, E. A. The tallage of 6 Edward II. (Dec. 16th, 1312) and the Bristol Rebellion Trans. Bristol and Gloucestershire Arch. Soc. I 894-95.

1959. Hale, M. A short treatise touching Sheriff's Accompts. 1716.

1960. A treatise . . concerning the Custom of Goods imported and exported. Collection of Tracts (ed. F. Hargrave), Vol. I. Dublin, 1787.

196r. Hall, H. The Antiquities and Curiosities of the Exchequer. I89I.

1962. - Customs Revenue of England. 1885.

1963. - The Receipt Roll of the Exchequer for Michaelmas Term, 3 I Henry II., A.D. 1185. Preface. Studies in Economics and Political Science (W. A. S. Hewins). I899.

1964. - The Red Book of the Exchequer. Rolls Series. Vol. III. (Preface). 1896.

1965. - The system of the Exchequer. Pipe Roll Society's Publications, Vol. III. "The 'Dot' system of the Exchequer," ibid., Vol. VII. I 884 , etc.

1966. Johnson, C. The Exchequer Chamber under Edward II. Eng. Hist. Rev., Vol. XXI. 1906. 1967. Madox, T. The History and Antiquities of the Exchequer. 1769.

1968. Maitland, F. W. Domesday Book and Beyond. Cambridge, 1897.

1969. Milne, P. L'Impôt des Aides sous l'Ancien Régime, I360-1791. 1908.

1970. Niemeyer, N. An Assessment for the Fortieth of 1232. Eng. Hist. Rev. 1909. 
I971. Niese, H. Die Verwaltung des Reichsgutes im I 3 Jahrhundert. Innsbruck, I905.

1972. Parow, W. Compotus Vicecomitis. Berlin, 1906.

1973. Piton, C. Les Lombards en France et à Paris. I 892-3.

1974. Powell, E. A Suffolk Hundred in the Year I283. I9IO.

1975. Prov, M. Esquisse de la politique monétaire des rois de France du Xe au XIIIe siècle. IgOI.

1976. Ramsay, Sir J. H. Statistics from Subsidy Rolls of Edward II. Eng. Hist. Rev. 1890-9. 1977. - Accounts, Edward III. to Richard III. Antiquary, Vol. I. to XVIII. I 880-1888.

The Financial chapters in the same author's History of England are also valuable. (Nos. $75^{8-761 .)}$

1978. Roscher, W. and Gerlach, O. System der Finanzwissenshaft. Stuttgart, I90I.

1979. Round, J. H. The alleged Debate on Danegeld in 1163. Eng. Hist. Rev., Vol. V. 1890.

1980. The Commune of London and other Studies. 1899 .

1981. Danegeld and the Finance of Domesday. Domesday Studies (P. E. Dove). 1888.

1982. - Feudal England. I895.

1983. - Gafol. Eng. Hist. Rev., Vol. V. 1890.

1984. - The great carucage of I 198 . Eng. Hist. Rev., III., I 888 ; IV., I 889.

1985. - The Revenue of Henry III. Eng. Hist. Rev., Vol. XIII. I 898.

1986. Scofield, C. L. A voluntary Subsidy levied by Edward IV. in the Province of Canterbury, 1462. Eng. Hist. Rev., Vol. XXIII. 1908.

1987. SinClair, Sir J. The History of Public Revenue of the British Empire . . from the remotest periods . . . to Michaelmas, 1802 . 1803-4. 
1988. Spangenaerg, H. Hof und Zentralverwaltung der Mark Brandenburg im Mittelalter. Leipzig, 1908.

1989. Stevenson, G. H. Finance. 1910. (J. E. Sandys): A Companion to Latin Studies.

1990. Thомas, F. S. The Ancient Exchequer of England. 1848 .

1991. Turner, G. J. The Exchequer at Westminster. Eng. Hist. Rev., Vol. XIX.

1992. The Sheriff's Farm. Trans. of R. Hist. S., (N.S.), Vol. XII. 1898.

1993. VINTRY, A. Etudes sur le régime financier de la France avant la Révolution de 1789 , t. I., Ve-XIIIe sic̀cle. I878.

1994. Whitwell, R. J. The Revenue and Expenditure of England under Henry III. Eng. Hist. Rev., Vol. XVIII. 1903.

1995. WILLARD, J. F. Edward III.'s negotiations for a Grant in 1337. Eng. Hist. Rev., Vol. XXI. 1906.

1996. Zeumer, K. Die deutschen Städtesteuern insbesondere die städtischen Reichsteuern im 12, u. I3 Jahrhundert. Staats-und Socialwissenschaftliche Forschungen. Leipzig, 1878.

\section{(e) Commercial Relations and Regulations.}

1997. Albe, E. Marchands de Cahors à Londres au XIIIe siècle. Cahors, 1908.

1998. Arup, E. Studien i Engelsk og Tysk Handels Historie, 1350-1850. 1907.

1999. Ashley, W. J. James and Philip van Artevelde. 1883 .

I999A. - History of the English Wool-trade. I 887. 2000. Bachtold, H. Der norddeutsche Handel im I 2 und beginnen den 13 Jahrhundert. Berlin, Leipzig, 1910.

2001. BEER, A. Allgemeine Geschichte des Welthandels. Wien, 1860-84. 
2002. Beissel, S. Geldwerth und Arbeitslohn im Mittelalter. Freiburg im Br., 1885.

2003. Below, G. v. Die Verwaltung des Mass-und Gewichtswesens im Mittelalter. Münster, I893.

2004. Bond, E. A. Extracts from the Liberate Rolls, relative to Loans supplied by Italian Merchants to the Kings of England in the I 3 th and $14^{\text {th }}$ centuries. Archeologia, Vol. XXVIII. I840.

2005. Borchgrave, E. DE. Coup d'oeil sur les colonies belges qui s'établirent en Angleterre pendant le moyen âge. Bullet. de l'Acad. d'Archéolog. d'Anvers, I.

2006. Bourne, H. R. F. English Merchants. I 886. 2007. Brissaud, D. Les Anglais en Guienne. Paris, I 865 .

2008. Bruyssel, E. van. Histoire du commerce et de la marine en Belgique. Brussels, r 86I-65. 2009. Bugge, A. Handelen mellem England og Norge indtil Begyndelsen af de I5de Aarhundrede. Norsk Historisk Forening, Historisk Tidsskrift, Raekke III., Bd. 4. Christiania, I 898 .

Commerce between England and Norway before the fifteenth century.

2010. - Studier over de norske byers selvstyre og handel fōr Hanseaterns tid. Ibid., I899. Christiania, I 899.

Self-government and trade of the Norse towns before the time of the Hansards.

20II. - Gotlændingernes Handel paa England og Norge omkring I300. Ibid., 3 Række, Bind V., pp. I 45-I80. Christiania, I 899.

The Gothland trade with England and Norway about 1300 .

2012. Carlier, C. La Commerce en France sous les Rois de la Première Race.

2013. Caro. G. Beiträge zur älteren deutschen Wirtschafts-und Verfassungsgeschichte. Leipzig, I905. 
2014. Cunningham, W. The Commercial Policy of Edward III. Trans. of the Royal Hist. Soc. N.S., Vol. IV.

2015. Differee, H. C. De Geschiedenis van den Nederlandschen Handel tot den Val der Republik. Amsterdam, 1908.

2016. FABER, R. Dic Entstehung des Agrarschutzes in England. Strasburg, 1888.

2017. Finot, J. Etude historique sur les rélations commerciales entre la France et la Flandre au moyen âge. Paris, 1894 .

2018. Flenley, R. London and Foreign Merchants in the reign of Henry VI. English Hist. Rev. 1910.

2019. Fris, V. Schets van den economischen Toestand van Vlaanderen in het Midden der 15 de Ecuw. Ghent, 1900. Koninklijke Vlaamsche Academie voor Taal en Letterkunde.

2020. Funck-Brentano, F. Philippe le Bel en Flandre. Les Origines de la Guerre de Cent Ans. Paris, 1897.

2021. Giuseppi, M. S. Alien Merchants in England in the Fifteenth Century. Trans. of the Royal Hist. Soc., N.S., Vol. IX. 1895.

2022. Guicciardini, L. Descrittione di tutti Paesi Bassi. Antwerp, 1588.

2023. Henderson, G. The Norse Influence on Celtic Scotland. Glasgow, I9Io.

2024. Holtze, F. Das berliner Handelsrecht im 13 und 14 Jahrhunderte. Berlin, 1880. Schriften des Vereins für die Geschichte der Stadt Berlin. 2025. Die Berliner Handelsbesteuerung und Handelspolitik im 13 und 14 Jahrhundert. Schriften des Vereins für die Geschichte der Stadt. Berlin, I88I.

2026. Hutchinson, L. Oriental Trade and the Rise of the Lombard Communes. Quarterly fourn. of Economics, Vol. XVI., pp. 413-432. 1902. 
2027. Huvelin, P. Travaux récents sur l'histoire de la lettre de change. Annales de Droit commercial français, étranger et intern. I90I.

2028. Imbart de la Tour, H. D. La liberté commerciale en France au XIIe et XIIIe siècles. I 890.

2029. JАсов, G. Der nordisch-baltische Handel der Araber im Mittelalter. Leipzig, I 887.

2030. Jansen, M. Die anfänge der Fugger, bis I 494 . Leipzig, 1907. Studien zur Fuggengeschichte.

203I. Kalischer, E. Beiträge zur Handelsgeschichte der Klöster zur Zeit der Grossgrundherrschaften. Berlin, I9I I.

2032. Kuntzel, G. Ueber die Verwaltung des Massund Gewichtswesens in Deutschland während des Mittelalters. Leipzig, I896. Staats und Sozialwissenschaftliche Forschungen 13.

2033. Laborde, L. E. S. J. De, Marquis. Les Ducs de Bourgogne. Paris, I849-52.

2034. Lamprecht, K. Deutsches Wirtschaftsleben im Mittelalter. Leipzig, I 886.

2035. LAw, T. G. Manufacture etc. in the Fourteenth Century. (Historical Essays, 1904.)

2036. Lapsley, G. T. The Flemings in Eastern England in the Reign of Henry II. English Historical Review. 1906.

2037. Lingelbach, W. E. Internal Organization of the Merchant Adventurers of England. 1902. Trans. R. Hist. Soc., N.S., XVI.

2038. Loisel, S. Essai sur la législation économique des Carolingiens d'a près les Capitulaires. Caen, I904.

2039. Lunt, W. E. The Financial System of the Mediæval Papacy in the light of recent literature. Quarterly Fournal of Economics. Vol. XXIII. (I 909 ), Pp. 25 I-295.

2040. Macpherson, D. Annals of Commerce. 1805 . 204I. Magnusson, E. Notes on Shipbuilding and Nautical Terms of old in the North. 1906. 
2042. Mas Latrie, L. de. L'officium Robarie à Gênes au moyen âge. Bibliothìque de l' Ecole des Chartes T. 53. Paris, 1892.

2043. -Du droit de marque ou de représailles au moyen âge. 1875 .

2044. MAYER, E. Zoll, Kaufmannschaft und Markt zwischen Rhein und Loire bis in das 13 Jahrhundert. Germanistische Abhandlungen zum L.XX Geburtstag $K$. von Maurer. Göttingen, 1893 .

2045. Michel, F. Les Ecossais en France-les Français en Ecosse. 1862.

2046. - Recherches sur le commerce, la fabrication et l'usage des étoffes de soie, d'or et d'argent et autres tissus précieux en ocrident, principalement en France, pendant le moyen âge. 1852. 2047. Molard, F. Banque de St. Georges (Archives des Missions, ser. III. t. 6). Paris, 1880.

2048. Moluwo, C. Dic ältesten lübischen Zollrollen. Lübeck, I 894 .

2049. Nansen, F. In Northern Mists. Trsl. I9I I. 2050. NAUDE, W. Die Getreidehändelspolitik der europäischen Staaten vom I 3-I 8 Jahrhunderte. Berlin, r 896.

2051. Owen, L. V. D. The connection between England and Burgundy during the $15^{\text {th }}$ century. (Stanhope essay.) 1909.

2052. Pedersen, R. Handelsforholdene og Handelspolitikken i Norden, etc. Viborg, 1852.

2053. Peruzzi, S. L. Storia dei Commercio e dei Banchieri di Firenze, etc. Florence, 1868.

2054. Pigeonneau, H. Histoire du commerce de la France. $1885-9$.

2055. - Le cycle de la croisade et de la famille de Bouillon. Paris, 1877 .

2056. Poelman, H. A. Geschiedenis van den Handel van Noord-Nederland gedurende het Merovingische en Karolingische tijdperk. Hague, 1908. 
2057. Poole, S. Lane. The Barbary Corsairs. I 890. 2058. Priebatsch, E. Der märkische Handel am Ausgange des Mittelalters. Berlin, I899. Schriften des Vereins für die Geschichte der Stadt Berlin.)

2059. KEY, E. Les Colonies franques de Syrie des XIIe et XIIIe siecles. I 884 .

2060. Rudolph, T. Die niederländischen Kolonien der Altmark im I 2 Jahrhundert. Berlin, I889. 206i. Schanz, G. Zur Geschichte d. Kolonisation u. Industrie in Franken. m. Urkunden. Erlangen, I 884 .

2062. Englische Handelspolitik gegen Ende des Mittelalters. Leipsic, I 88I.

2063. Schaube, A. Das Konsulat des Meeres in Pisa. Ein Beitrag zur Geschichte des Seewesens, der Handelsgilden und des Handelsrechts im Mittelalter. Staats-und socialwissenschaftliche Forschungen. Bd. VIII., Heft 2. Leipzig, I 878, etc.

2064. Schneider, G. Die finanziellen Beziehungen der Florentiner Bankiers, etc. Leipzig, 1899. See No. 2572 .

2065. Scotr, W. R. The constitution and finance of English, Scottish, and Irish joint-stock companies to I720. Cambridge, I9I I.

2066. Shillington, V. M., and Chapman, A. B. W. Commercial relations between England and Portugal. I904.

2067. Simon, A. T. History of the Wine Trade. 1906. 2068. Schulte, A. Die Fugger in Rom 1495-1523, mit Studien zur Geschichte des kirchlichen Finanzwesens jener Zeit. Leipzig, I904.

2069. - Geschichte des mittelalterlichen Handels und Verkehrs zwischen Westdeutschland und Italien mit Ausschluss von Venedig. Badischen historischen Kommission. Leipzig, I9oo. 
2070. Sommerlad, T. Die Rheinzölle im Mittelalter. Halle a. S., I894.

207I. Varenbercil, E. Histoire des relations diplomatiques entre le Comté de Flandre et l'Angleterre au moyen âge. Brussels, Ghent, 1874 .

2072. WeTZEL, E. Das Zollrecht der deutschen Könige von den ältesten Zeiten bis zur goldenen Bulle. Breslau, 1893. Untersuchungen zur deutschen Staats und Rechtsgeschichte. (O. Gierke.)

2073. Yver, G. Le commerce et les marchands dans l'Italie méridionale au 13 et au 14 siècle. Paris, 1903.

The Hanse.

2074. BAHr, K. Handel und Verkehr der deutschen Hanse in Flandern im 14 Jahrhundert. Leipzig, I9II.

2075. Barthold, F. W. Geschichte der deutschen Hanse. 1909.

2076. Clephian, R. C. The Hanseatic Confederation, with special reference to the rise and progress of the English factories and trading connections with Newcastle-upon-Tyne. Archaologia Aeliana, Vol. XV., iii. New Series. Newcastle-on-Tyne, 1892.

2077. Daenele, E. Die Blütezeit der deutschen Hanse, I370-1474. Berlin, I905.

2078. Daenell, E. R. Die kölner Konföderation vom Jahre 1367 und die Schonischen Pfandschaften. Hansisch - Dänische Geschichte, 1367-85. Arndt's Leipziger Studien. Leipzig, I894.

2079. Denicke, H. Die Hansestäde, Danemark und Norwegen, 1369 bis 1 376 . Halle, 1880 .

2080. Grandinson, C. G. Studier i HanseatiskSvensk Historia till 1365 . Stockholm, 1884-5. 
2081. Häpke, R. Brügges Entwickelung zum mittelalterlichen Weltmarkt. Berlin, I908.

2082. Hartunng, J. Norwegen und die deutsche Seestädte. Berlin, I 877 .

2083. Hirsch, T. Danzigs Handels-und Gewerbsgeschichte unter der Herrschaft des deutschen Ordens. Leipzig, 1858.

2084. Keutgen, F. Die Beziehungen der Hanse zu England im letzten Drittel des I4 Jahrhunderts. Giessen, I890.

2085. Kiesselbach, G. A. Die wirtschaftlichen Grundlagen der deutschen Hanse und die Handelsstellung Hamburgs bis in die zweite Hälfte des I4 Jahrhundert. Berlin, 1907.

2086. Lappenberg, J. M. Urkundliche Geschichte des hansischen Stahlhofes zu London. Hamburg, I $85 \mathrm{I}$.

2087. Lindner, T. Die deutsche Hanse. Ihre Geschichte und Bedeutung. I9II.

2088. LüDERs, H. Hamburgs Handel und Gewerbe am Ausgang des Mittelalters. I9IO.

2089. Pauli, R. Der hansische Stahlhof in London. Bremen, I 856 .

2090. Schäfer, D. Die Hanse. Monographien zur Weltgeschichte (E. Heyck). Bielefeld und Leipzig, 1903.

2091. Die Hansestädte und König Waldemar von Dänemark. Jena, 1879 .

2092. Stein, W. Die Genossenschaft der deutschen Kaufleute zu Brügge in Flandern. Berlin, 1890. 2093. Stieda, W. Hansisch-Venetianische Handelsbeziehungen im 15 Jahrhundert. Rostock, 1894.

The Staple.

2094. Davidson, J., and Gray, A. The Scottish Staple at Veere. I909.

2095. Rooseвоom, M. P. The Scottish Staple in the Netherlands. The Hague, rgro. 
2096. Williams, E. Staple Inn; Customs House, Wool Court and Inn of Chancery. London, 1906.

The fows.

2097. Gross, C. The Exchequer of the Jews of England in the Middle Ages. (Anglo- Jewish Historical Exhibition Papers, 1887.) I 888.

2098. Herzfeld, L. Handelsgeschichte der Juden des Alterthums. Braunschweig, 1879.

2099. Hoffmann, M. Der Geldhandel der deutschen Juden während des Mittelalters bis zum Jahre 1350. Staats-und Socialwissenschaftliche Forschungen (G. Schmoller). Heft, 152. Leipzig, 1910.

2100. JAcoBs, J. The Jews of Angevin England. Eng. Hist. by Contemporary Writers. 1893.

2101. The London Jewry, I 290. 1894.

2102. LeOnaRD, G. H. The Expulsion of the Jews by Edward I. Trans. R. Hist. Soc., N.S., Vol. V. I891.

2103. LAZARD, L. Essai sur la condition des Juifs dans le domaine royal au XIIIe siècle. I887.

2104. Stовве, O. Die Juden in Deutschland während des Mittelalters. Leipzig, 1902.

2105. Süssmann, A. Die Judenschuldentilgungen unter König Wenzel. Schriften der Gesellschaft zur Förderung der Wissenschaft des Fudentums. Berlin, 1907.

The Military Orders.

2106. Addison, C. G. The Knights Templars. London, 1852.

2107. Curzon, H. DE. La Règle du Temple. Société de l' Histoire de France. Paris, 1886.

2108. Delisle, L. Mémoire sur les Opérations financières des Templiers. Memoires de l'Institut National de France, Académic des Inscriptions et Belles Lettres, Vol. XXXIII., pt. 2, p. I. Paris, I889. 
2rog. Dupuy, P. Histoire de l'ordre militaire des Templiers, depuis son établissement jusqu'à sa suppression. Bruxelles, I75I.

2110. Ferris, E. The Financial Relations of the Knights Templars to the English Crown. American Historical Review, VIII. New York, 1903.

2III. Finke, H. Papsttum und Untergang des Templerordens. Vorreformations-geschichtliche Forschungen, Vols. IV. and V. Münster i. W., 1907.

21 12. Le Roulx, J. Delaville. Les Hospitaliers en Terre Sainte et à Chypre, I I00-I 310. Paris, 1904.

2113. Perkins, C. The Knights Templars in the British Isles. Eng. Hist. Rev., Vol. XXV. 1910. 2II4. PrUTZ, $H$. Die finanziellen Operationen der Hospitaliter. Sitzungsberichte der königlichbayerischen Akademie der Wissenschaften. München, 1906.

2115. -Die geistlichen Ritterorden. Berlin, 1908. $2116 .-E n t w i c k l u n g$ und Untergang des Tempelherrenordens. Berlin, 1888 .

2117. Stevenson, W. B. The Crusaders in the East. Cambridge, 1907.

2118. Wood, H. The Templars in Ireland. Proc. $R$. Irish Acad., XXVI. Dublin, 1907.

\section{B.-LOCAL GOVERNMENT.}

\section{(a) The Manor.}

History and Franchises.

2119. Allen, W. F. Essays and monographs. Boston, 1890. (Pp. 240-344: On the English village community and the rural population of England in the Middle Ages.)

2120. Andrews, C. M. The Old English Manor. Baltimore, I892. 
2121. Ashlfy, W. J. The Anglo-Saxon Township. Quarterly Journal of Economics, VIII., 34561. Boston, I 894 .

2122. Early Teutonic Society. International Quarterly, VIII., 236-61. New York, 1903-4. 2123. BEQUeT, A. Les grands domaines et les villes de l'Entre-Sambre et Meuse sous l'Empire romain. Annales de la Société Archéologique de Namur, XX., 9-26. Namur, 1893.

2124. Brusser, N. Nouvel examen de l'usage général des fiefs en France. Paris, 1750.

2125. BrYAN, E. A. The mark in Europe and America. Boston, 1893.

2126. BRUNner, H. Zur Rechtsgeschichte der römischen und germanischen Urkunde. Berlin, 1880 .

Pp. 149-208: Das Angelsăchsische Landbuch.

2127. Cardenas, F. DE. Ensayo sobre la historia de la propriedad territorial en España. Madrid, 1873 -[5].

2128. Chadwick, H. M. Studies on Anglo-Saxon institutions. 1905.

2129. ChOPE, R. P. The early history of the manor of Hartland. Transactions of the Devonshire Association, XXXIV., 418-54. London, Plymouth, 1902.

2030. Copinger, W. A. History of the parish of Buxhall in the county of Suffolk. IgOz.

2131. Corbett, W. J., and Methold, T. T. The rise and devolution of the manors in Hepworth, Suffolk. Suffolk Institute of Archoology, Proceedings, X., 19-48. Bury St. Edmunds [1898-1900].

2132. Cullum, J. The history and antiquities of Hawstead, and Hardwick, in the county of Suffolk. I8I3.

2133. Dupin, A. M. Traité des apanages. Paris, 1835 . 
2i 34. Fustel de Coulanges, N. D. Histoire des institutions politiques de l'ancienne France. Paris, 1888-92. (Vol. IV., L'Alleu et la domaine rurale; I889. Vol. V., Les origines du système feodal ; I 890.$)$

2135. Le Problème des Origines de la Propriété Foncière. Questions Historiques, Paris, 1893. Revue des Questions Historiques, April, I889; transl. I89I-introductory chapter on the English Manor by W. J. Ashley.

2136. GARNIER, R. M. History of the English Landed Interest. I892.

2137. - Annals of the British Peasantry. 1895.

2 138 . Gomme, G. L. The Village Community with special reference to the origin and form of its survivals in Britain. Contemporary Science Series, 1890.

2139. Green, W. A. Historical antiquities of Ackworth. I9Io.

2140. Hall, H., and Bird, S. R. S. Notes on the history of Crown lands. Antiquary, XIII., I-6, 85-6, 89-95, I 59-62, I 94-6. I 886.

214 . Hansen, G. Agrarhistorische Abhandlungen. Leipzig, I 880-4.

2142. Hasbach, W. A history of the English agricultural labourer. Trans. by Ruth Kenyon. I908.

2143. Haskins, C. H. Normandy under William the Conqueror. Amer. Hist. Review (April). New York, I909.

2144. Haxthausen, A. Freiherr von. Ueber die Agrarverfassung in Norddeutschland. Berlin, I 829.

2145. Hinojosa, E. DE. El regimen senorial y la question agraria en Cataluña durante la edad media. Madrid, I905.

2 I46. Hone, N. J. The Manor and Manorial Records. Antiquary's Books. Igo6. [B.] 
2147. Hodgson, J. A history of Northumberland. I820-I 858 .

2148. Jrssopp, A. The land and its owners in past times. Studies by a recluse, pp. $143-83$. 1893 .

2149. Kennedy, J. The Manor and Parish Church of Hampstead and its vicars. 1906.

2150. Koenen, H. J. De Nederlandsche Boerenstand historisch beschreven. Haarlem, 1858 .

2151. Lapsley, G. T. The County Palatine of Durham. 1900.

2152. The origin of property in land. American Historical Revice, VIII., 426. New York, 1903.

2153. Lewis, E. A. The decay of tribalism in North Wales. Transactions of the Honourable Society of Cymmrodorion, 1902-3, pp. I-75. 1904.

2154. Lyte, Sir H. C. Maxwell. A history of Dunster. 1909.

2155. MaIne, H. S. Lectures on the early History of Institutions. $\mathbf{1} 875$.

2156. Village Communities in the East and West. 1876.

2157. Maitland, F. W. The survival of Archaic Communities. Law Quarterly Review, IX., 36-50, $211-28.1893$.

2158. Domesday Book and Beyond. Cambridge, 1897 .

2159. The history of a Cambridgeshire Manor. Eng. Hist. Review, IX., 417-439. 1904.

2i6o. Massingberd, W. O. History of Ormsby-cumKetsby. [1893.]

216I. Maurer, G. v. Einleitung zur Geschichte der Mark, Hof, Dorf-und Stadtverfassung der öffentlichen Gewalt. Vienna, I 896.

2i62. Meitzen, A. Siedelung und Agrarwesen, etc. Berlin, 1895.

2163. Morkill, J. W. The Manor and Park of Roundhay. Thoresby Society, Miscellanea, I., 217 seq. Leeds, I 889 . 


\section{A SELECT BIBLIOGRAPHY OF}

2164. Morris, M. C. F. Nunbarnholme : Its history and antiquities. 1907.

2165. Niessen, P. v. Geschichte der Neumark im Zeitalter, ihrer Entstehung und besiedelung. Landsberg a. W., 1905.

2166. Opet, O. Die erbrechtliche Stellung der Weiber in der Zeit der Volksrechte. Breslau, I888. (Pp. 75-82 : Das angelsächsische Recht.)

2167. Oтто, H. Eine Briefsammlung vornehmlich zur Geschichte italienischer Kommunen in der zweiten Hälfte des Mittelalters. Quellen aus italienischen Archiven. Bd. II., Hft. I. Rome, 1908.

2i68. Pearman, M. T. History of the Manor of Bensington. 1896.

2i69. Reichel, O. J. Hulham Manor: A sketch, historical and economic. Devonshire Assoc., XXVII., 403-36. London, Plymouth, 1895.

2I70. Pollock, Sir F. Oxford Lectures and other Discourses. 1890. (Ch. v., The English Manor.)

2171. Robertson, E. W. Historical Essays. I 872. 2172. Round, J. H. The Domesday "Manor." Eng. Hist. Review, XV., 293-302. 1900.

2173. Schotтe, H. Studien zur Geschichte der westfälischen Mark und Markgenossenschaft mit besonderer Berücksichtigung des Münstererlandes. Münster, 1908.

2174. Scrope, G. P. History of the Manor and Ancient Barony of Castlecombe. 1852 .

2175. Séz, H. Les classes rurales et le régime domanial en France. Paris, I90I.

2176. Seевонм, F. The historical importance of the Cymric tribal system. Trans. of the Honourable Soc. of Cymmrodorion. 1897.

2177. The Land question. Quarterly Review, N.S., VII., 89-107. 1870. 
2178. SеЕвонм, F. The English Village community. 1890 ; reprinted, 1896 .

2179. - The Tribal System in Wales. 1904.

2180. Tribal Custom in Anglc-Saxon law. I902. 218I. Seeliger, G. Die soziale und politische Bedeutung der Grundherrschaft im früheren Mittelalter. (Abhandlungen der philologisch-historischen Klasse der königl. sächsischen Gesellschajt der Wisscnschaften, B. XXII., No. I.) Leipzig, 1903.

2182. The State and Seignorial Authority in early German History. Amer. Hist. Review, Jan., 1909.

2183. Siebeck, O. Das Arbeitssystem der Grundherrschaft des deutschen Mittelalters. Tübingen, 1904.

2184. Stevens, J. Parochial history of St. Mary Bourne, Hants. I 888 .

2185. Stewart-Brown, R. The wapentake of Wirral. 1907.

2186. TREGELlis, J. A. A history of Hoddesdon, in the county of Herts. I908.

2187. Vinogradoff, P. The growth of the Manor. I9II.

2188. Wales, Royal Commission on Land in Wales and Monmouthshire (Report). I896. (pp. I33-49.)

2I89. WALKER, J. K. Almonbury in Feudal times. rorkshire Archaological and Topographical Journal, II., I-34. Wakefield, 1873.

2190. WARD, J. Manorial history of Newcastle-underLyme. The Borough of Stoke-upon-Trent. 1843.

Ch. xiv. and xv., pp. 297-336: Manorial economy.

2191. Watson-Taylor, J. Erlestoke and its Manor lords. Wilts. Archaological and Natural History Magazine, XXXIII., 295-309, 37783 ; XXXIV., 42-102. Devizes, I905-6. 
2 I92. WEBB, P. C. A short account of Danegeld with some further particulars relating to William the Conqueror's Survey. 1756.

2193. Williams, J. The Mediæval History of Denbighshire. I860.

2194. Wiтtich, W. Die Grundherrschaft in Nordwestdeutschland. Leipzig, 1896.

2195. Zinkeisen, F. Die Anfänge der Lehngerichtsbarkeit in England. Berlin [1893].

Tenures and Services.

2196. Adams, G. B. Anglo-Saxon Feudalism. American Hist. Review, VII. New York, I90I.

2197. Allen, J. Inquiry into the rise and growth of the royal prerogative in England. I830. 2198. Amira, K. von. Erbenfolge und Verwandtschafts-Gliederung nach den alt-niederdeutschen Rechten. Munich, 1874.

2199. Ashley, W. J. The character of Villein Tenure. Annals of the American Academy of Political and Social Science, Jan., I89I. Philadelphia.

2200. Astre, T. An account of the Tenures and Customs, etc., of the Manor of Great Tey, Essex. I795.

2201. Bradshaw, F. The decline and fall of Serfdom in Durham. Archeologia Aeliana, 3 rd ser., IV., 91-105. Newcastle-on-Tyne, I908.

2202. Brownlow, W. R. Lectures on Slavery and Serfdom in Europe. 1892.

2203. Brunner, H. Das anglonormannische Erbfolgesystem. Leipzig, 1889 .

2204. Buckstaff, F. G. Married Women's Property in Anglo-Saxon and Anglo-Norman law. Annals of the American Acdemy of Political and Social Science, IV., No. 2, Pp. 33-64. I 893 . 
2205. Ciannock, R. S. On ancient Manorial Customs, Tenures, etc., in the county of Essex. 1870.

2206. Cheyney, E. P. The Disappearance of English Serfdom. Eng. Hist. Review, XV., 20-37. 1900.

2207. Clark, A. Serfdom on an Essex Manor, 13081378. Eng. Hist. Review, XX., 479-83. 1905.

2208. Corner, G. R. On the Custom of Borough English. Bury and West Suffolk Archaological Institute, Proceedings, II., 227-4I. 1859.

2209. - On the Custom of Borough English, as existing in the County of Sussex. Sussex Archao'ogical Collections, VI., I64-89. 1853.

2210. Dalrymple, J. An essay towards a general history of Feudal Property in Great Britain. 1759 .

2211. Davenport, F. G. The decay of Villeinage in East Anglia. Trans. Royal. Hist. Soc., XIV., 123-41. 1900.

2212. Digby, Sir K. E. An Introduction to the History of the Law of Real Property. Oxford, I897.

2213. Earle, J. A Handbook to the Land Charters and other Saxonic documents. Introduction. 1888.

2214. Elton, C. J. The Tenures of Kent. 1867

2215. Custom and Tenant right. 1882.

2216. Enclish Peasantry, The rights, disabilities, and usages of the ancient. Law Magazine and Law Review, XII., 259-63; XIII., 30-4I, 205-16; XIV., I-II, 338-56; XV., 42-50, 292-300; XVI., I-17. 1862-4.

2217. Fuchs, C. J. Der Untergang des Bauernstandes und das Aufkommen der Gutsherrschaften. nach archivalischen Quellen aus Neuvorpommern und Rügen. Strassburg, 1888. 
2218. Fuller, E. A. Tenures of land in Cirencester. Bristol and Gloucestershire Archeological Society Trans., II., 285-319. Bristol, I877-8. 2219. Goddard, C. V. Customs of the Manor of Winterbourne Stoke. Wilts. Arch. and Nat. Hist. Mag., XXXIV., 208-I 5. Devizes, 1906. 2220. Gomme, G. L. Widowhood in Manorial Law. Archaological Review, II., I84-197. I889.

2221. Hazeltine, H. D. The gage of Land in Mediaval England. Reprinted from the Harvard Law Review, XVII., No. 8 ; XVIII., No. I. I904.

2222. Hazlits, W. C. Tenures of Land and Customs of Manors originally collected by Thomas Blount. I 874 .

2223. Hibbert-Ware, S. Customs of a Manor in the North of England during the fifteenth century, etc. 1822 .

2224. Jeanton, G. Leservage en Bourgogne. Paris, Igo6 2225. Lapsley, G. T. Cornage and Drengage. American Historical Review, IX., 670-95. New York, I904.

2226. Leadam, I. S. Villainage in England. Political Science Quarterly, VIII., 653-76. New York, etc., I 893 .

2227. The Last Days of Bondage in England. Law Quarterly Review, IX., 348-65. 1893.

2228. The Security of Copyholders in the fifteenth and sixteenth centuries. English Historical Review, VIII., 684-96. I 893.

2229. Locke, $R$. The customs of the Manor of Taunton and Taunton Deane. 1785.

2230. Maitland, F. W. The beatitude of Seisin. Law Quarterly Review, IV., 24-39, 286-99. I 888.

2231. The Suitors of the County Court. English Historical Review, III., 4I7-2I. I 888.

2232. -Northumbrian Tenures. English Historical Review, V., 625-32. 1890. 
2233. Malden, H. E. Bondsmen in Surrey under the Tudors. Trans. Royal Hist. Soc., XIX., 305-7. 1905.

2234. Villeinage in the Weald of Surrey. Surrey Arch. Coll., XX., 143-52. 1907.

2235. Massingberd, W. O. The Lincolnshire Sokemen. Eng. Hist. Review, XX., 699-703. 1905. 2236. Montcomery, W. E. The History of Land Tenure in Ireland. 1889.

2237. Moore, S. A. Rights of Common upon the Forest of Dartmoor and the Commons of Devon. Dartmoor Preservation Association Publications, I. 1890.

2238. Neilson, N. Customary Rents. Oxford Studies (ed. P. Vinogradoff), II. Oxford, 1910.

2239. PAGE, T. W. The End of Villainage in England. Publications of the American Economic Association, 3rd series, Vol. I., No. 2. New York, 1900.

2240. Palmer, A. N., and Owen, E. A History of Ancient Tenures of Land in the Marches of North Wales. I910.

2241. Pollock, Sir F. Early English Freeholders. Trans. Devon. Assoc., XXVI., 25. London, Plymouth, 1894.

2242. The Land Laws. English Citizen Series. 1896.

2243. Pope, A. Some ancient customs of the Manors of Stratton and Grimston, Co. Dorset. Dorset. Nat. Hist. and Antiq. Field Club, XXX., 83-96. 1909.

2244. RaGG, F. W. The feoffees of the Cliffords, 1283-1482. Cumb. and Westm. Antiq. and Arch. Soc., N.S., VIII., 253-330. Kendal, 1908.

2245. Robinson, T. The Common Law of Kent, or Customs of Gavelkind, and Borough English (C. I. Elton and H. J. Mackay). I897. 
2246. Roeder, F. Die Familie bei den Angelsachsen. Halle, 1899 .

2247. Round, J. H. Feudal England. I 895.

2248. - The King's Sergeants and Officers of State. I9II.

2249. SAndys, Charles. Consuetudines Kanciae: A History of Gavelkind and other remarkable Customs in the County of Kent. 1851 .

2250. Savine, A. Copyhold cases in the Early Chancery Proceedings. English Historical Review, XVII., 296-303 1902.

2251. Bondmen under the Tudors. Royal Hist. Soc. Trans., XVII., 235-86. 1903.

2252. English Customary Tenure in the Tudor period. Quarterly Fournal of Economics, XIX., 33-80. I905.

Summary of his Russian work, "The English Village of the Tudor Period."

2253. Schmid, K. Jus primæ noctis. Freiburg, I88I.

2254. Scrope, G. P. On the self-government of small Manorial Communities. Wiltshire Archeol. and Nat. Hist. Magazine, III., 145-63. 1857. 2255. Scrutton, T. E. Commons and Common Fields 1887 .

2256. Sеввонм, F. Feudal Tenures in England. Fortnightly Review, N.S., VII., 89-187. 1870.

2257. Seignobos, C. Le régime féodale en Bourgogne jusqu' en I360. Paris, I882.

2258. Shillibeer, H. B. The ancient customs of the Manor of Taunton Deane. I82I.

2259. Sмiтн, L. T. The English Manor. Quarterly Review, CCVII., I 29-152. 1907.

2260. Somner, W. A Treatise of Gavelkind. 1726. 2261. Spelman, H. The original growth, propagation, and condition of Feuds and Tenures by Knight-service, in England. Spelman's Posthumous Works, I-46. 1723. 
2262. TAYLOR, S. The history of Gavelkind. 1663. 2263. Vinogradoff, P. Villainage in England. Oxford, 1892.

2264. English Society in the Eleventh Century. Oxford, igos.

2265. Folcland. English Historical Review, VIII., I-17. 1893 .

2266. - Transfer of Land in old English Law. Harvard Law Review, XX. (1906-7), 532-548. Cambridge, Mass., 1907.

2267. - An illustration of the continuity of the Openfield system. Quarterly Fournal of Economics, XXII., 62-73. 1908.

2268. Agricultural Services. Economic Journal, X., 308-22. 1900.

2269. - Zur Wergeldfrage. Vierteljahrschrift für Social- und Wirtschaftsgeschichte, B. III., 534-54. Leipzig, 1905.

2270. Watkins, C. A Treatise on Copyholds. I 825.

2271. Williams, B. An account of the Officers in a

Manor in Oxfordshire with remarks upon the hide of land. Archeologia, XXXIII., 269-78; XXXV., 470-74; 1849, I853.

2272. Williams, J. Principles of the Law of real property (ed. T. C. Williams). I9ı.

2273. WRIGHT, T. On the political condition of the English Peasantry during the Middle Ages. Archaologia, XXX., 205-44. 1844 .

2274. Wrotresley, G. The Forest Tenures of Staffordshire. William Salt Archaological Society, X., pt. I, pp. I89-243. 1907.

2275. Yeatman, P. Some observations upon the law of Ancient Demesne. I884.

Agrarian Economy.

2276. Ashrey, W. J. Introduction to English Economic History and Theory. 1892.

2277. - Surveys, Historic and Economic. 1900. 
2278. D'Avenel, G. Histoire économique de la propriété en France, des salaires, des denrées et de tous les prix en général. Paris, I 894, etc. 2279. Balaguer, V. Estado de la cultura española y especialmente Catalana en el siglo 15. Barcelona, I 893 .

2280. Ballard, A. The Domesday Inquest. Antiquary's Books. 1906.

2281. Woodstock Manor in the Thirteenth Century. Vierteljahrschrift für Social-und Wirtschaftsgeschichte, VI. Stuttgart, I908.

2282. Baring, F. Domesday Book and the Burton Cartulary. English Historical Review, XI., 98-102. 1896. (Ibid., XII., 258-90, Domesday and some $13^{\text {th }}$ century Surveys, 1897.$)$

2283. The Hidation of some southern counties. English Historical Review, XIV., 290-9. 1899. 2284. -Domesday Tables. Statistics of Surrey, Berks, Middlesex, Herts, Bucks, and Bedford. 1909.

2285. Bennetr, R., and Elton, J. History of Cornmilling. I898-1904.

2286. Borderie, A. DE LA. Notes sur la culture de la vigne en Bretagne avant le XVe siècle. Assoc. Breionne, Bulletin Archéologique, ser. 3, t. x. Saint-Brien, 1892.

2287. C[LARK], G. T. Manorial particulars of the County of Glamorgan. Archaolog a Cambrensis, 4th ser., VIII., 249-69; IX., I-2I, II4-34. I 877-8.

2288. Curtler, W. H. R. A short history of English Agriculture. I909.

2289. Davenport, F. G. The Economic Development of a Norfolk Manor, I086-1565. Cambridge 1906.

2290. Dove, P. E. Domesday Studies. I888-9I. 229I. Ellis, H. General Introduction to Domesday Book. Record Commission. 1833 . 
2292. Eyton, R. W. A key to Domesday Analysis and digest of the Dorset Survey. 1878 .

2293. -Domesday Studies: An analysis and digest of the Somerset Survey. 1880.

2294. An analysis and digest of the Staffordshire Survey. 1881.

2295. Fuller, E. A. Cirencester, the Manor and the Town. Bristol and Gloucestershire Archaol. Soc. Trans., IX., 298-344. Bristol, 1884-5.

2296. Gareis, CARL. Bemerkungen zur Kaiser Karls des Grossen Capitulare de Villis. Germanistische Abhandlungen zum LXX. Geburtstag Konrad von Maurers. Göttingen, 1893.

2297. GAY, E. F. Inclosures in England in the sixteenth century. Quarterly Fournal of Economics, XVII., 576-97. Boston, 1903.

2298. - and LeAdam, I.S. The Inquisitions of Depopulation in 1517 and the "Domesday of Inclosures." Trans. Royal Hist. Soc., XIV., 23I-303. 1900.

2299. Grbbins, H. DE B. Industry in England. 1896. (Ch. iv., Manor and Manorial system; ch. v. Domesday Book and the Manors; ch. viii., Agriculture in Mediæval England.)

2300. Grünberg, Karl. Die Bauernbefreiung und die Auflösung des Gutsherrlich-bäuerlichen Verhältnisses in Böhmen, Mähren, und Schlesien. Leipzig, 1894.

230r. Hale, W. H. H. The Domesday of St. Paul's of the year I222. (Introduction.) Camden Society. 1858 .

2302. - Registrum sive Liber Irrotularius et consuetudinarius Prioratus Beatæ Mariæ Wigorniensis. (Introduction.) Camden Society. I 865.

2303. Hart, W. H. Historia et Cartularium Monasterii Sancti Petri Gloucestrix. Vol. III. (Intro.), XCIII.-CIX. Rolls Series. 1863-7. 
2304. Hudson, W. The abbot of St. Benet and his tenants after the Peasant Revolt of I38I. Antiquary, XXIX., 21 5-8, 256-9. 1894.

2305. Inman, A. H. Domesday and Feudal statistics, with a chapter on Agricultural statistics. I900.

2306. Johnson, A. H. The disappearance of the small Landowner. I909.

2307. KnapP, G. F. Die Bauernbefreiung und der Ursprung der Landarbeiter in den älteren Teilen Preussens. Leipzig, 1887.

2308. Kovalevsky, M. Die ökonomische Entwickelung Europas bis zum Beginn der kapitalistischen Wirtschaftsform. Berlin, I90I-5.

2309. Leadam, I. S. The Inquisition of 1517 . Inclosures and Evictions. Trans. of the Royal Hist. Soc., N.S., VI., I67-314. 1892.

2310. - The Domesday of Enclosures, I517-18. Introduction. Royal Hist. Society. I 897.

23I I. Lizier, A. L'economie rurale dell' eta prenormanna. Palermo, 1907.

23I 2. Lloyd, J. E. Early Welsh Agriculture. I894.

2313. Mamroth, K. Die agrarische Entwickelung Englands. Fahrbücher für Nationalökonomie und Statistik, III., Folge. B. XVIII., heft 6, pp. 721-77. Jena, 1899.

2314. Munford, G. An analysis of the Domesday Book of the County of Norfolk. 1858 .

2315. NAsse, E. The Agricultural Community of the Middle Ages and Inclosures of the sixteenth century in England. (Trans. by Col. H. A. Ouvry.) 1872 .

23i6. Neilson, N. Economic conditions on the Manors of Ramsey Abbey. 1898.

2317. PAGE, T. W. DieUmwandlung der Frohndienste in Geldrenten, etc. Baltimore, 1897

2318. Palmer, A. N. Notes on ancient Welsh measures of land. Archaologia Cambrensis, $5^{\text {th }}$ series, XIII., I-I9. 1896. 
2319. Phear, J. B. The Hide examined. Devon. Assoc., XXXVI., 380-9. London. Plymouth, 1904.

2320. Pollock, Sir F. A brief Survey of Domesday. English Historical Revicw, XI., 209-230. 1896.

2321. Rogers, J. E. T. A History of Agriculture and Prices in England. 1259-1400. 1866.

2322. - The Economic interpretation of History. I 888 .

2323. Six centuries of Work and Wages. I 890.

2324. Round, J. H. The Commune of London and other studies. I 899.

2325. - The hidation of Northamptonshire. Eng. Hist. Revicw, XV., 78-86. 1900.

2326. - The Burton Abbey Surveys. Eng. Hist. Review, XX., 275-89. 1905.

2327. Scrutton, T. E. Commons and Common Fields. 1887.

2328. Slater, G. The English Peasantry and the enclosure of Common Fields. 1906.

2329. Stenton, F. M. Types of Manorial Structure in the Northern Danelaw. Oxford Studies (P. Vinogradoff), Vol. II. Oxford, I9ro.

2330. Taylor, C. S. An analysis of the Domesday Survey of Gloucestershire. Bristol and Gloucestershire Archeological Society. Bristol, I889.

2331. The pre-Domesday hide of Gloucestershire. Bristol and Gloucestershire Archeological Soc. Trans., XVIII., 288-319. Bristol, I895.

2332. ThüNen, H. Recherches sur l'influence que le prix des grains, la richesse du sol et les impôts exercent sur les systèmes de culture. (Transl. J. Lavverrière.) Paris, 1851 .

2333. WAlker, B. On the Inquisitio Comitatus Cantabrigiensis. Cambridge Antiquarian Soc. Communications, VI., 45-64. Cambridge, 1891. 
2334. WALker, B. On the Measurements and valuations of the Domesday of Cambridgeshire. Camb. Antiq. Soc. Communications, V., 93I29. Cambridge, I 884 .

2335. Zinkeisen, F. The Anglo-Saxon Courts of Law. Political Science Quarterly, X., 132-44. New York, etc., I895.

\section{JURISDICTIONS.}

2336. Blakesley, G. H. Manorial Jurisdiction. Law Quarterly Review, V., I I 3-3I. I889.

2337. Hearnshaw, F. J. C. Leet Jurisdiction in England. Southampton Record Society. Southampton, I908.

2338. Hudson, $\vec{W}$. Leet jurisdiction in the City of Norwich during the I 3 th and I 4 th centuries. (Introduction.) Selden Society. V. 1892.

2339. Maitland, F. W. Select Pleas in Manorial and other Seignorial Courts. Selden Society, II. Introduction. I 889.

2340. Morris, W. A. The frankpledge system. I9Io.

234I. Ritson, J. The Jurisdiction of the Court Leet. I8I6.

2342. Sheppard, H. B. Courts Leet and the Court Leet of the Borough of Taunton. Somerset Archaological and Natural History Society. Taunton, Igog.

2343. Waitz, G. Deutsche Verfassungsgeschichte. Berlin, I 880-2.

$$
\text { App: I., Frankpledge. }
$$

(b) The Towns.

General Municipal History.

2344. Armstrong, E., and Langton Douglas, R. The States of Italy. I907, etc.

2345. Bateson, M. Borough Customs. (Introduction.) Selden Society. I904-6. 
2346. Below, G. v. Das ältere deutsche Städtewesen und Bürgertum. Monographien zur Weltgeschichte (E. Heyck). Bielefeld und Leipzig, 1898.

2347. BLoK, P. J. Geschiedenis eener Hollandsche Stad. Eene hollandsche Stad in de Middeleeuwen. Hague, 1910.

2348. Gosses, I. H. Stadsbezit in Grond en Water gedurende de Middeleeuwen. Leyden, 1903.

2349. Graffin, A. Les biens communaux en France, étude historique et critique. 1899.

2350. Harvey, A. The Castles and Walled Towns of England. 1911.

2351. Hettema, F. B., and Telting, A. Een Bezoek aan een Nederlandsche Stad in de XIVde Eeuw. Hague, 1906.

2352. KeUtgen, F. Untersuchungen über den Ursprung der deutschen Stadtverfassung. Leipzig, I895.

2353. Kuske, B. Das Schuldenwesen der deutschen Städte im Mittelalter. Tübingen, 1904.

2354. Lamprecht, K. Deutsches Städtewesen am Schluss des Mittelalters. Sammlung von Vorträgen für das deutsche Volk (W. Frommel and A. B. I. F. Pfaff). Heidelberg, 1884.

2355. Madox, T. Firma Burgi. 1726.

2356. Maitland, F. W. Township and Borough. Cambridge, 1898.

2357. The Origin of the Boroughs. Eng. Hist. Review, XI., 13-19. 1896.

2358. Merewether, H. A., and Stephens, J. A. History of Boroughs and Municipal Corporations of the United Kingdoms. 1835 .

2359. Pirenne, H. L'Origine des Constitutions Urbaines au Moyen Age. Revue Hist., T. 53, p. 73.

2360. Raynouard, F. J. M. Histoire du droit municipal en France sous la domination romaine et sous les trois dynasties. Paris, 1829 . 
236r. Report of the Commissioners appointed to inquire into the Municipal Corporations in England and Wales; with Appendices. 1835-8. (Ibid., for Ireland, I835-6; ib., for Scotland, I 835-6.)

2362. RietsChEL, S. Untersuchungen zur Geschichte der deutschen Stadtverfassung. Leipzig, 1905.

2363. Riviere, A. Histoire des biens communaux en France depuis leur origine jusqu' à la fin du XIIe siècle. Paris, I856.

2364. Soyer, J. Etude sur la communauté des habitants de Blois. Paris, I895.

2365. Vincent, J. M. Municipal problems in Mediæval Switzerland. Fohns Hopkins University Studies, XI., XII. Baltimore, 1905.

Local Municipal History.

2366. Page, W., and Doubleday, H. A. Victoria History of the Counties of England. 1900, etc. 2367. Ormerod, G. History of Cheshire. I 875-82. 2368. Hutchins, J. History and Antiquities of the County of Dorset (William Shipp and J. W. Hodson). I 86I-70.

2369. Baines, E. History of the County Palatine and Duchy of Lancashire (J. Croston). I 888-93.

2370. History of Northumberland (issued under the direction of the Northumberland County History Committee). I 893, etc.

2371. Hudson, W. Records of the City of Norwich (Introduction). I906-Io.

2372. Eyton, R. W. Antiquities of Shropshire. I $854-60$.

2373. Hearnshaw, F. J. C. Court Leet Records (Introduction). Southampton Record Society. 1905.

2374. Hoare, R. C. History of Wiltshire. 1822-43. 
Histories of Towns at Special Periods or of Special Groups of Towns.

For the Hanse Towns see above, A (e), Nos. 2124 "q.

2375. Ballard, A. The Domesday Boroughs. I904.

2376. The Cinque Ports under Henry II. English Historical Revicw, 1909.

2377. Boyle, J. R. The Lost Towns of the Humber. I 889.

2378. Berg van Middleburgh, F. L. De Nederlanden en het Hanseverbond. Utrecht, 1833 .

2379. Brequigny, L. G. O. F. de. Recherches sur les communes et les bourgeoisies. Ordonnances des rois de France, t. XI. et XII. 1838.

2380. Bulmerince, A.v. Der Ursprung der Stadtverfassung Rigas. Leipzig, I894.

238I. Bunge, F. G. v. Die Stadt Riga im I 3 und 14 Jahrhundert. Leipzig, I878.

2382. Burrows, M. Cinque Ports. I 888.

2383. Butler, W. F. T. The Lombard Communes. 1906.

2384. Curie-Seimbres, A. Essai sur les villes fondées dans le Sud-Ouest de la France aux XIIIe et XIVe siècles. Toulouse, I880.

2385. Daumet, G. Calais sous la domination anglaise. Arras, 1902.

2386. Dechaisnes. Essai sur les relations de la Ville de Douai et l'Angleterre.

2387. Dubrulle, $H$. Cambrai à la fin du moyen âge, XIIIe-XVIe siècle. Tours, 1904.

2388. Durieux, A. Les drapiers Cambrésiens. Cambrai, 1886.

2389. Fagniez, G. Etudes sur l'Industrie et la Classe industrielle à Paris au XIIle et au XIVe siècle. Boulogne, 1877 .

2390. Flammermont, J. Histoire de l'Industrie à Lille, 1897. 
2391. Franklin, A. Dictionnaire historique des arts, métiers et professions exercés dans Paris depuis le XIIIe siècle. Paris, Leipzig, I906.

2392. Les Corporations ouvrières de Paris du XIIe au XVIIIle siècle. Paris, I884, etc.

2393. Freville, de Lorme C. E. DE. Mémoire sur le commerce maritime de Rouen. Rouen, 1857.

2394. Germain, A. C. Histoire du commerce de Montpellier. Montpellier, I861.

2395. Green, A. S. Town Life in the $15^{\text {th }}$ century. I 894 .

2396. Halphen, L. Paris sous les Premiers Capétiens, 987-I 223. I 909.

2397. Lambert. Essai sur le régime municipal et l'affranchisement des communes du moyen âge. I 882 .

2398. Liesegang, E. Niederrheinisches Städtewesen vornehmlich im Mittelalter. Untersuchungen zur deutschen Staats und Rechtsgeschichte, Vol. LII. (O. Gierke). Breslau, 1897 .

2399. Longnon, A. Paris pendant la domination anglaise, I420-36. Soc. d'Histoire de Paris. 1878.

2400. Luchaire, A. Les Communes françaises à l'époque des Capétiens directs (L. Halphen). Paris, I9I I.

240I. Nirnheim, H. Hamburg und Ostfriesland in der ersten Hälfte des 15 Jahrhunderts. Hamburg, 1890.

2402. Potter, Fr. De, and Broeckaert, J. Geschiedenis der gemeenten van Oost-Vlaanderen. Ghent, I 864 , etc.

2403. Sandeman, G. A. C. Calais under English Rule. 1908.

2404. TRenholme, N. M. Risings in the English Monastic Towns in 1327. I901.

2405. Vignie, M. Les Bastides du Perigord.

2405A. VIliari, P. (Transl. L. Villari). The two first Centuries of Florentine History. I90I. 
Specimens of Town Historics.

2406. Townsend, J. History of Abingdon. 1910.

2407. TAte, G. History of the Borough, Castle, and Barony of Alnwick. Alnwick, I 866-9.

2408. Baigent, F. J., and Millard, J. E. History of the ancient Town and Manor of Basingstoke. Basingstoke, 1889.

2409. Nielsen, Y. Bergen fra de aeldste Tiden indtil Nutiden. Christiania, 1877.

2410. Scotr, J. Berwick-upon-Tweed: The history of the Town and Guild. 1888.

24II. Balaseue, T. Etudes Historiques sur la Ville de Bayonne. Bayonne, I862.

2412. Poulson, G. Beverlac: or the . . History . . of Beverley. Beverley, 1829.

2413. Seyer, S. Memoirs Historical and Topographical of Bristol. Bristol, I821.

2414. Michel, F. Histoire du commerce, etc., à Bordeaux. Bordeaux, I867.

2415. Lennel, F. Histoire de Calais. Calais, 1908, etc.

2416. Cooper, C. H. Annals of Cambridge. Cambridge, I842-1900.

2417. Maitland, F. W., and Bateson, M. Charters of the Borough of Cambridge. (Introduction.) Cambridge, I90I.

2418. Morris, R. H. Chester in the Plantagenet and Tudor reigns. Chester [1894].

2419. Marwick, J. D. River Clyde and the Clyde Burghs. Igog.

2420. Harris, M. Dormer. Life in an Old English Town. (Coventry.) 1898.

2421. Statham, S. P. H. History of the Castle, town and Port of Dover. 1899.

2422. Surtees, R. History and Antiquities of the County Palatinate of Durham. 1908.

2423. Menmuir, C. The Durham Domesday Book. 1906. 
2424. Woodruff, C. E. History of the town and Port of Fordwich. Canterbury, 1895.

2425. Marwick, J. D. Early Glasgow (Robert Renwick). Glasgow, I9II.

2426. Guildford in the Olden Time (G. C. Williamson). 1904.

2427. Boyle, J. R. Early History of the Town and Port of Hedon. Hull and York, 1895.

2428. Johnson, Ric. Ancient Customs of the City of Hereford. I 882.

2429. Marle, R. van. Hoorn au moyen âge. Hague, I9IO.

2430. Wodderspoon, J. Memorials of the Ancient Town of Ipswich. 1850.

243r. TAYLOR, W. Antiquities of King's Lynn. Lynn, 1844 .

2432. PRICE, A. C. Leeds and its neighbourhood. Oxford, igog.

2433. Thompson, J. The History of Leicester. 1849.

2434. Kurth, G. La cité de Liège au Moyen Age. Brussels, rgio.

2435. Muir, Ramsay. History of Municipal Government in Liverpool. (Introduction.) Liverpool, 1906.

2436. Kingsford, C. L. Chronicles of London. 1905. 2437. Lethaby, W. R. London before the Conquest. 1902.

2438. Loftie, W. J. History of London. I 884.

2439. Rijswijk, B. van. Geschiedenis van het Dordtsche Stapelrecht. Hague, 1900.

2440. Riley, H. T. Memorials of London and London Life in the $13^{\text {th }}$, 14th, and $15^{\text {th }}$ centuries, A.D. 1276-1419. 1868.

244I. Sharpe, R. R. London and the Kingdom. 1894. 2442. Brand, John. History and Antiquities of the Town and County of Newcastle-upon-Tyne, including an account of the Coal Trade of that place, etc. 1789 . 
2443. Renwick, R. Peebles: Burgh and parish in early history. 1903.

2444. Boys, W. Collections for a History of Sandwich, with notices of the Cinque Ports. Canterbury, 1792.

2445. Owen, H., and Blakeway, J. B. History of Shrewsbury, I825.

2446. Davies, J. S. History of Southampton, i 883. 2447. Toulmin, J., and Savage, J. The History of Taunton. Taunton, 1822 .

2448. Hedges, J. K. History of Wallingford. I88I. 2449. Gaskin, R. T. Old Seaport of Whitby. Whitby, I909.

2450. Palmer, A. N. History of the Town and Parish of Wrexham. Wrexham, 1884-1903. See also No. 2240.

2451. Swinden, H. History and Antiquities of Great Yarmouth. Norwich, 1772.

2452. Drake, Francis. Eboracum : or the History and Antiquities of the City of York. 1736.

Gilds : General Accounts of Gilds; also Accounts of the Gilds of certain towns.

2453. Abram, W. A. Memorials of the Preston Guilds. Preston, I882.

2454. Bain, E. Merchant and Craft Guilds: A history of the Aberdeen Incorporated Trades. Aberdeen, 1887 .

2455. Bateson, M. Cambridge Gild Records. (Introduction.) Cambridge Antiquarian Society. Cambridge, 1903.

2455A. Boissonade, P. Essai sur l'organisation du travail en Poiton. Poitiers, 1900.

2456. Bormans, St. Le bon métier des tanneurs de l'ancienne cité de Liége. Liége, 1863.

2457. Colston, J. Incorporated Trades of Edinburgh. Edinburgh, 1891. 
2458. Doren, A. Deutsche Handwerker und Handwerkerbrüderschaften im mittelalterlichen Italien. Berlin, I903.

2459. Untersuchungen zur Geschichte der Kaufmannsgilden des Mittelalters. Städts-u. Socialwissenschaftliche Forschungen (G. Schmoller). Leipzig, I 893.

2460. Entwicklung und Organisation der Florentiner Zünfte im I 3 und I4 Jahrhundert. Städtsund Socialwissenschattliche Forschungen (G. Schmoller). Leipzig, I 897.

246I. Eberstadt, R. Ursprung des Zunftwesens und die älteren Handwerkerverbände des Mittelalters. Leipzig, 1900.

2462. Gierke, O. Das deutsche Genossenschaftsrecht. I868-81. Political theories of the Middle Ages. (Trans. F. W. Maitland.) Cambridge, I900.

2463. Gross, C. The Gild Merchant. Oxford, 1890. 2464. Hazlitt, W. C. Livery Companies of the City of London. 1892.

2465. Hegel, K. Städte und Gilden der germanischen Völker im Mittelalter. Leipzig, I891.

2466. Herbert, W. History of the Twelve Great Livery Companies of London. 1837.

2467. Hibbert, F. A. The Influence and Development of English Gilds. Cambridge, I891.

2468. Huyttens, J. Recherches sur les Corporations Gantoises, leur organisation civile, religieuse, militaire et commerciale. Ghent, I86I.

2469. Keutgen, F. Aemter und Zünfte. Jena, I903.

2470. Kramer, S. English Craft Gilds and the Government. New York, I905.

247 I. Lambert, J. M. Two thousand years of Gild Life. Hull, r891.

2472. Linden, H. Les gildes marchandes dans les Pays-Bas au moyen âge. Gand, 1896. 
2473. Marez, G. Des. L'Organisation du travail à Bruxelles au XVe siècle. Brussels, 1904.

2474. Marwick, J. D. Edinburgh Guilds and Crafts. Scottish Burgh Records Society. Edinburgh, 1909.

2475. Neuburg, C. Zunftgerichtsbarkeit und Zunftverfassung in der'Zeit vom 13-16 Jahrhunderte. Jena, 1880 .

2476. PAppenheim, M. Die altdänischen Schutzgilden. Breslau, 1885 .

2477. Schмidt, F. G. A. Handelsgesellschaften in den deutschen Stadtrechtsquellen des Mittelalters. Breslau, 1883. (Untersuchungen zur Deutschen Staats- und Rechtsgeschichte, XV.)

2478. Seligmann, E. R. A. Two chapters on the Mediæval Guilds of England. American Economic Association, Vol. II. Saratoga, 1887.

2479. Smith, J. Toulmin and L. Toulmin. English Gilds. Early English Text Society. 1870.

2480. UNwin, G. The Guilds and Companies of London. Antiquary's Books. I908.

2481. Vigne, F. DE. Moeurs et usages des corporations de métiers de la Belgique et du Nord de la France. Ghent, 1857.

2482. WILDA, W. E. Das Gildenwesen im Mittelalter. Berlin, I83I.

Crafts and Industries.

2483. Hildebrand, H. O. H. The Industrial Arts of Scandinavia in Pagan times. 1883. (South Kensington Muscum Art Handbooks.)

2484. Worsaal, J. J. A. The Industrial Arts of Denmark. 1883. (South Kensington Museum Art Handbooks.)

2485. Brown, R. History of Accounting and Accountants. 1905. 


\section{A SELECT BIBLIOGRAPHY OF}

2486. Young, S. Annals of the Barber Surgeons of London. I890.

2487. Lethaby, W. R. Westminster Abbey and the King's Craftsmen. 1906.

2488. Jupp, E. B. Historical Account of the Worshipful Company of Carpenters. 1887.

2489. DAw, J. Sketch of the Early History of the Worshipful Company of Butchers. 1890.

2490. FirTh, J. F. Coopers' Company, London: Historical Memoranda, etc. I 848 .

2491. Burkitt, E. H. Short History of the Worshipful Company of Curriers. I 906.

2492. Williams, W. M. Annals of the Worshipful Company of Founders of London. 1867. P.P.

2493. FretTon, W. G. Memorials of the Fullers' or Walkers' Guild, Coventry. Coventry, 1878 .

2494. Hartshorne, A. Old English Glasses. I 897. 2495. Beck, S. W. Gloves: Their Annals and Associations. 1883 .

2496. Chaffers, W. Gilda aurifabrorum : A history of English Goldsmiths and Plateworkers and their marks. 1890.

2497. CRIPPS, W. J. Old English Plate. 1906.

2498. Jackson, C. J. English Goldsmiths and their marks. I905.

2499. Heath, J. B. Some account of the Worshipful Company of Grocers of the City of London. I869. P.P.

2500. Kingdon, J. Abernethy. Archives of Grocers . . . of London. 1886.

2501. Nicholl, J. Some account of the Worshipful Company of Ironmongers. 1866. P.P.

2502. Noble, T. C. Brief history of the Worshipful Company of Ironmongers, I35I-I889. (APpendix.) 1889. P.P.

Containing an account of Blacksmiths' Compnay. 
2503. Black, W. H. History and Antiquities of Worshipful Company of Leathersellers. 1871 .

2504. Conder, E. Records of the Hole Craft and Fellowship of Masons. 1894 .

2505. BERRY, H. F. Records of the Dublin Gild of Merchants known as the Gild of the Holy Trinity. Dublin, 1900.

2506. WELCH, C. History of the Company of Paviors of London. I909. P.P.

2507. Masse, H. J. L. J. Pewter Plate. 1904.

2508. Sherwell, J. W. . . . A descriptive and

historical account of the Guild of Saddlers of London. 1889. P.P.

2509. Lindsay, W. History of Merchant Shipping. 1874 .

2510. WADMORE, J. F. Some account of the Worshipful Company of Skinners. 1902.

2511. Clode, C. M. Early History of the Guild of Merchant Taylors of London. 1888.

2512. Fox, F. F. Some account of the . . Merchant Taylors of Bristol. Bristol, I880. P.P.

2513. - and TAYLOR, J. Some account of the Guild of Weavers in Bristol. Bristol, 1889. P.P.

2514. Thomson, D. The Weavers' Craft, being a history of the Weavers' Incorporation of Dunfermline. Paisley, 1903.

2515. Milbourn, Thos. The Vintners' Company, etc. I888. P.P.

2516. Shone, W. Laws and Privileges of the Company of Vintners. 1818.

2517. Ashley, W. J. The Early History of the English Woollen Industry. 1887.

2518. James, J. History of the Worsted Manufacture in England. London, Bradford, 1857.

2519. YATES, J. Textrinum antiquorum: The art of Weaving among the Ancients. 1843 .

Part 1: On the raw materiale used for weaving. 
Fairs and Markets.

2520. Borel, F. Les Foires de Genève au quinzième siècle. Geneva, I892.

2520A. Bourquelot, F. Etudes sur les foires de Champagne, in Mémoires, etc. à l'Académie des Inscriptions. Paris, I865.

252 I. Buck, W. Der deutsche Handel in Nowgorod bis zur Mitte des I 4 Jahrhunderts. St. Petersburg, 1895.

2522. Elton, C. I., and Costelloe, B. T. C. On the Charters and Records of, in Report on Market Rights and Tolls, Vol. I., I889.

2523. Heins, M. La monnaie et le prix des choses à Gand au temps de Jacques van Artevelde. Brussels, 1886.

2524. Historical Account of Sturbridge, Bury, and the most famous Fairs in Europe, etc. Cambridge, 1773 .

2525. Huvelin, P. Essai historique sur le droit des Marchés et des Foires. Paris, I 897.

2526. Kitchin, G. W. On the Charter of Edward III. for St. Giles Fair, I349. Winchester, I 886.

2527. Morley, H. Memoirs of Bartholomew Fair, 1859.

2528. Rietschel, S. Markt und Stadt in ihren rechtlichen Verhältnis. Leipzig, I897.

2529. Walford, C. Fairs, Past and Present. 1883.

\section{C. -THE CHURCH.}

(a) General Works.

Europe.

2530. Bourgain, L. La chaire française au XIIe siècle. 1879 .

2531. Böhmer, H. Kirche und Staat in England u. in Normandie in XI. u. XII. Jahrhundert. Leipzig, 1899. 
2532. Ebner, A. Die kloesterlichen Gebetsverbrüderungen bis zum Ausgange des Karolingischen Zeitalters. 1890.

2533. Eckenstein, L. Woman under Monasticism. 1896.

2534. Maclear, G. F. A history of Christian Missions during the Middle Ages. 1863 .

2535. Milman, H. H. History of Latin Christianity. 1864 .

2536. Molinier, C. L'Inquisition dans le midi de la France. Paris, Toulouse, 1880.

2537. Montalembert, C. F. R. De. The Monks of the West (F. A. Gasquet). 1896.

2538. Samaran, C., and Mollat, G. La Fiscalité pontificale en France au XIVe siècle. Paris, 1905.

2539. Sommerlad, T. Die wirtschaftliche Thätigkeit der Kirche in Deutschland. Leipzig, 1900.

2540. Wells, C. L. The Church in the Age of Charlemagne. 1898 .

2541. Willson, T. B. History of the Church and State in Norway from the roth to the 16th century. 1903.

Great Britain.

2542. Coulton, G. G. The Monastic Legend. Mediaval Studies, No. I. 1905.

2543. - The Truth about the Monasteries. Contemporary Review, April, 1906.

2544. Dowden, J. The Medirval Church in Scotland: its constitution, organisation, and law. Glasgow, 1910.

2545. The Celtic Church in Scotland. 1894.

2546. Fosbroke, T. D. British Monachism. 1843.

2547. Gasquet, F. A. English Monastic Life. Antiquary's Books. 1904.

2548. The Old English Bible and other essays. 1908. 
2549. Hill, G. English Dioceses. A history of their Limits from the earliest times to the present day. I900.

2550. Hill, O'D. T. English Monasticism : its rise and influence. $\mathbf{I} 867$.

255 I. Reichel, O. J. Rise of the Parochial System in England.

2552. Robertson, E. W. Historical Essays in connexion with the Land, the Church, etc. Edinburgh, r872.

2553. Rowe, J. B. Cistercian Houses of Devon. Plymouth, 1878 .

2554. Savine, A. English Monasteries on the Eve of the Dissolution. Oxford Studies in Social and Legal History, Vol. I. Oxford, 1909.

2555. Trenholme, N. M. The Risings in the English Monastic Towns in 1327. Reprinted from American Historical Review, July, rgor.

(b) Relations with Rome, etc.

2556. Baumgarten, P. M. Aus Kanzlei und Kammer. Freiburg in B., 1907.

2557. Fabre, P. Recherches sur le denier de St. Pierre en Angleterre au moyen âge. Supplément aux Mélanges d'archéologie et d'histoire, etc., tom. XII. Paris, Rome, I892.

2558. Gaseuet, F. A. Henry III. and the Church. 1905 .

2559. Gotrlob, A. Aus der Camera Apostolica des I 5 Jahrhunderts. Innsbruck, r889.

2560. Die päpstlichen Kreuzzugssteuern des 13 Jahrhunderts. Heiligenstadt Eichsfeld, r892. 256r. Graham, R. The Taxation of Pope Nicholas. English Historical Review. 1908.

2562. Jensen, O. The Denarius Sancti Petri. Trans. Royal Historical Soc., N.S., XIX. I905.

2563. Jones, W. H. R. Early Annals of the Episcopate in Wilts and Dorset. I87I. 
2564. Kirsch, J. P. Les Collectories de la Chambre Apostolique vers le milieu du XIVe siècle. (Section II. : Compte Rendu du ze Congres Scientifique International des Catholiques.) Bruxelles, 1894 .

2565. KREHBieL, E. B. The Interdict: its History and its Operation. American Historical Assoc. Washington, 1909. [B.]

2566. Luard, H. R. On the relations between England and Rome. 1877.

2567. Makower, F. The Constitutional History and Constitution of the Church of England. 1895.

2568. Powell, E., and Trevelyan, G. M. The Peasants' Rising and the Lollards. 1899.

2569. Prutz, H. Jacques Cœurs Beziehungen zur römischen Kurie. Sitzungsberichte der Königlich, bayerischen Akademie der Wissenschaften. München, 1910.

2570. Samaran, C., and Mollat, G. La fiscalité pontificale en France au XIVe siècle. Paris, 1905. Bibliotheque des écoles françaises d' Athenes et de Rome, t. XCVI.

2571. Schaub, F. Der Kampf gegen den Zinswucher ungerechten Preis und unlautern Handel im Mittelalter von Karl den grossen bis Papst Alexander III. Freiburg im Bresgau, 1905.

2572. Schneider, G. Die finanziellen Beziehungen der florentinischen Bankiers zur Kirche von 1285 bis I 304 . Leipzig, I 899.

2573. TANGL, M. Das Taxwesen der päpstlichen Kanzlei vom 13 bis zur Mitte des 15 Jahrhunderts. Mittheilungen des Instituts für oesterrichischen Geschichtsforschung. Innsbruck, 1892.

\section{(c) Clerical Life.}

2574. Christie, J. Some account of Parish Clerks I 893 . 


\section{2

2575. Coulton, G. G. Priests and People before the Reformation. Contemporary Review, June and July, 1907. (Mediaval Studies, No. 8.)

2576. - Religious Education before the Reformation. Contemporary Review, October, 1906. (Mediaval Studies, No. 7.)

2577. Cutrs, E. L. Parish Priests and their People in the Middle Ages in England. I898.

2578. Gasquet, F. A. The Layman in the Pre-Reformation Parish. Catbolic Trutb Soc. P., n.d.

2579. - Parish Life in Mediæval England. Antiq. Books. 1906. [B.]

2580. Hennessy, G. Novum Repertorium Ecclesiasticum Parochiale Londinense. 1898.

See No. 2591.

2581. Jessopp, A. Before the Great Pillage. 190I.

2582. The coming of the Friars. 1890.

2583. Wall, J. C. An Old English Parish. 1907.

2584. Wharton, H. A Defence of Pluralities. I692.

(d) Revenue and Endowments.

General.

2585. Bright, J. S. The Endowments and Establishment of the Church of England (L. T. Dibdin). 1885.

2586. Derby. The Chronicles of the Collegiate Church - . of All Saints (J. C. Cox and W. H. St. J. Hope). I 881.

2587. Ely. On the purchase of the manor and advowson of Mepal in the I $4^{\text {th }}$ century by the Prior and Convent of (by Archdeacon Chapman). Cambridge Antiquarian Soc. Antiquarian Communications, N.S., I. 1893.

2588. Hereford Cathedral, Charters and Records of (by W. W. Capes). 1908.

2589. LEsNe, E. Histoire de la propriété ecclésiastique en France. I. Epoques romaine et mérovingienne. Univ. de Lille, Mémoires et Travaux. 1910. 
2590. Mrall, E. Title Deeds of the Church of England to her Parochial Endowments. 1885.

2591. Newcourt, R. Repertorium Ecclesiasticum Parochiale Londinense. 1708-10.

2592. Reichel, O. J. Churches and Church Endowments in the 11 th and 12 th centuries. Trans. of Devonshire Association. Vol. XXXIX., 1907, pp. 360-93.

2593. Thomas, P. Le Droit de Propriété des Laíques sur les Eglises et les Patronages Laíques au moyen-âge. Bibliothèque de l'école des Hautes Etudes, Sciences Religieuses, XIX. Paris, 1906.

Tithe.

2594. Grove, H. Alienated Tithes in Appropriated and Impropriated Parishes. 1896.

2595. Reichel, O. J. The Treasury of God and the Birthright of the Poor. Archaologia. 1907.

2596. Selborne (Roundell Palmer), Earl of. Ancient Facts and Fictions concerning Churches and Tithes. 1892.

2597. SElden, J. History of Tithes. 1726.

(e) Miscellaneous Sources of Revenue.

Penance.

2598. Göller, E. Die päpstliche Pönitentiarie. Bibliothek des Kgl. Preuss. Hist. Instituts in Rom. Rome, 1907.

2599. Lea, H. C. A Formulary of the Papal Penitentiary in the $13^{\text {th }}$ century. 1892 .

Indulgences.

2600. Documents illustrating the history of St. Paul's Cathedral (W.S. Simpson). Camden Soc. 1880. 2601. FleTE, J. The History of Westminster Abbey (J. Armitage Robinson). Notes and Documents relating 10 Westminster Abbey, II. 1909. 


\section{A SELECT BIBLIOGRAPHY OF}

2602. LEA, H. C. A history of Auricular Confession and Indulgences in the Latin Church. Philadelphia, 1896.

2603. LÉpicier, A. M. Indulgences: their origin, nature, and development. 1895 .

Relics, Sbrines, etc.

2604. Molinier, A. Les Obituaires français au moyen âge. 1890 .

2605. Röhricht, R. Deutsche Pilgerreisen nach dem heiligen Lande. Gotha, 1889.

2606. WALL, J. C. Shrines of British Saints. Antiquary's Books. 1905.

\section{$(f)$ Privilege of Sanctuary.}

2607. Cox, J. C. The Sanctuaries and Sanctuary Seekers of Mediæval England. Antiquary's Books. I9II.

2608. Mazzinghi, T. J. Sanctuaries. Stafford, i887. 2609. TRenholme, N. M. The Right of Sanctuary in England. University of Missouri Studies, Vol. I., No. 5. Missouri, 1903.

(g) Domestic Economy (Monastic and Parochial). General.

26ro. Benedictines. The English Black Monks of S. Benedict (E. L. Taunton). 1898. 2611. Carthusians (Somerset), A history of the. (M. E. Thompson.) 1895 .

261 2. Cistercians. The Architecture of the (E. Sharpe). 1874 .

2613. - The Settlement of the, in England (A. M. Cooke). English Hist. Review, VIII. 1893. 2614. - Etudes sur l'état intérieure des abbayes cisterciennes et principalement de Clairvaux au XIIe et XIIIe siècles. (H. D. D'Arbois de Jubainville.) 1858 . 
2615. Franciscans, Side-lights on the (by G. G. Coulton). Independent Review, Feb. 1905. (Mediceval Studies, No. 3.)

2616. Freiburger historische Studien (A. Buechi and others). Freiburg (Schweiz), 1905.

Vol. I., Social life of monasteries.

2617. The Friars, and how they came to England (by

Father Cuthbert, O.S.F.C.). 1903.

2618. The Scottish Grey Friars (W. M. Bryce).

Edinburgh and London, 1909.

26rg. Friars, The Failure of the (G. G. Coulton).

Hibbert Fournal, Jan. 1907.

2620. Saint Gilbert of Sempringham and the Sempringhamites (R. Graham). 1901.

2621. The Gilbertines in Scotland (J. Edwards).

Glasgow, 1904.

2622. The Parish Clergy of the $13^{\text {th }}$ and $14^{\text {th }}$ centuries (H. G. Richardson). Royal Hist. Soc.

Trans. I9II-I 2.

\section{Local.}

2623. Ashburton, The Parish of, in the $15^{\text {th }}$ and 16 th centuries (J. H. Butcher). 1870.

2624. Balmerino and its Abbey (J. Campbell). I 899.

2625. Bath, The Benedictines in (J. C. Fowler). 1895. 2626. Beauchief Abbey, Historical memorials of (S. O. Addy). 1878.

2627. Carron Abbey (W. Rye). I 889.

2628. Beeston Priory, otherwise Moulney (A. Jessopp). Norfolk Antiquarian Miscellany, III. Norwich, 1887.

2629. Beverley, The Friars Preachers or Black Friars of (C. F. R. Palmer). rorks Archaol. Fourn., VII. 1882 .

2630. Bristol, Notes on the accounts of the Churchwardens of the Parish of St. Ewen's ( $\mathrm{J}$. Maclean). Bristol and Glouc. Archaological Soc. Trans., XV. 1891. 
2631. Bury, On the Abbey of St. Edmund at (M. R. James). Cambridge Antiquarian Society. Cambridge, 1895.

2632. Cambridge, The Priory of St. Radegund (A. Gray). Cambridge Antiquarian Society. I 898 .

2633. Canonsleigh, Remarks on some early Charters and Documents relating to the Priory of (C. S. Percival). Archaologia, XL. 1866.

2634. Canterbury, Customary of the Benedictine Monasteries of St. Augustine, Canterbury, and St. Peter, Westminster (E. M. Thompson). Henry Bradshaw Soc., XXIV. 1902.

2635. - The Friars-Preachers, and Black Friars, of (C. F. R. Palmer). Archcologia Cantiana, XIII. I 880 .

2636. Chertsey Abbey (L. Wheeler). 1905.

2637. Coventry, Memorials of the Whitefriars (by W. G. Fretton). Birmingham and Midlands Institute Archæological Trans. 1872, 1873.

2638. Memorials of the Charterhouse (W. G. Fretton). Birmingham and Midlands Institute Archæological Trans. 1874, 1878.

2639. Dartford Priory, The History of (C. F. R. Palmer). Arcbeological Fournal, XXXVI., XXXIX.

2640. Dewsbury . . . its Ecclesiastical History (J. Hunter). Coll. Topograpbica et Genealogica (No. 820), I. I834.

2641. Doncaster, The House of the Grey Friars (F. R. Fairbank). Yorks. Archaological Soc. Fourn. XII. I 893.

2642. Eggleston Abbey (J. F. Hodgson). rorks. Archaol. Soc. Fourn., XVIII., I29-32. Leeds, 1905.

2643. Ely, The Sacrist Rolls of (by F. R. Chapman). I907. 
2644. Furness, Abbey of St. Mary in (by W. H. St. J. Hope). Cumberland and Westmoreland Antiquarian and Archaological Soc. Trans., XVI. 1900.

2645. Gloucester, The Friars Preachers, or Black Friars, of (by C. F. R. Palmer). Archaological Journal, XXXIX. 1882.

2646. Hurley. St. Mary's, Hurley, in the Middle Ages (by F. T. Wethered). 1898.

2647. King's Lynn, The Friars Preachers or Black Friars of (C. F. R. Palmer). Archaological Fournal, XLI. I 884 .

2648. - Our Borough; our Churches (E. M. Beloe). I 899 .

2649. Kirklecs Priory (G. Armytage). rorks. Archeological Fournal, XX. 1908.

2650. Kingston-upon-Thames, Early history of the Church of (by A. Heales). 1883.

2651. Lacock Abbey, Annals and Antiquities of (W. L. Bowles and J. G. Nichols). 1835.

2652. London, Bequests to the Black Friars of, during the Fifteenth century (B. Jarrett). English Historical Review. I910.

2653. Malton Priory, The Finance of (R. Graham), Royal Hist. Soc. Trans., N.S., XVIII.

2954. Mary-church, A visitation of, I 301 (Rt. Rev. Mgr. Brownlow). Trans. Devon. Assoc.). 1893.

2655. Maxstoke Priory (J. R. Holliday). Birmingham and Midlands Institute Archaological Trans. 1874 .

2656. Merton Priory, Records of (A. C. Heales). 1898. (1), Chronological narrative; (2), Appxes. of Records ; (3), Biblio.

2657. Middleham, Documents relating to the Foundation and Antiquities of the Collegiate Church of (W. Atthill). Camden Soc. 1847. 
2658. Middlesborough. Ecclesiastical Middlesborough in Mediæval times.-Yorks. Archaological Fournal, XVIII. Leeds, 1905.

2659. Northampton, History of the Church of the Holy Sepulchre (J. C. Cox and R. M. Serjeantson). I 897 .

2660. Norwich. Goods and Ornaments of Norwich Churches in the Fourteenth century $(\mathrm{H}$. Harrod). Norfolk and Norwich Archaeological Soc. Norfolk Archaology, V. 1856.

2661. - The Riot between the monks and citizens of, in 1272 (W. Rye). Norfolk Antiquarian Miscellany II. 1883 .

2662. Oxford, The Black Friars of (W. G. D. Fletcher). 1882.

2663. Cistercian Scholars at (R. C. Fowler). Engl. Hist. Review. 1908.

2664. The Grey Friars in (A. G. Little). Oxford Hist. Soc. 1892.

2665. The Oldest Account Book of the University of (S. Gibson). Engl. Hist. Review. 1909.

2666. Paisley, The Abbey of, from its foundation till its dissolution (J. C. Lees). Paisley, 1878 .

2667. Peterborough, History of the Church of ( $\mathrm{S}$. Gunton). 1686.

2668. Pontefract, Letter from Stephen, Prior of St. John of (G. F. Duckett). rorks. Archaological Fourn. IX. 1886.

2669. Ramsey Abbey, Economic Conditions on the Manors of (N. Neilson). 1899.

2670. Rochester, The Architectural History of the Cathedral, Church, and Monastery (W. H. St. John Hope). 1900.

2671. Romsey Abbey, Records of (H. G. D. Liveing). Winchester, 1906.

2672. St. Albans Cathedral and Abbey Church (H. J. B. Nicholson). 1898. 
2673. Shrewsbury, The Friars Preachers or Black Friars of (C. F. R. Palmer). Reliquary. 1885. 2674. Tanridge Priory, History of (A. C. Heales). 1885.

2675. Walton Priory, Yorkshire (by W. H. St. John

Hope). East Riding Antiquarian Soc. Trans.

VIII. 1900.

2676. Wells Cathedral : Its foundation, constitution, history and statutes (H. E. Reynolds). [1880.] 2677. Westminster, Gilbert Crispin, Abbot of (J. A. Robinson). Notes and Documents relating to Westminster Abbey, III. I9II.

2678. Wiltshire, The Black Friars of (C. F. R.

Palmer). Wilts. Archeological and Nat. Hist. Mag., XVIII. 1879.

2679. Yarm, The Friars Preachers or Black Friars of

(C. F. R. Palmer). Archaological Fournal, XXXVII. 1880.

2680. York, The Friars Preachers or Black Friars of

(C. F. R. Palmer). rorks. Archaological Fournal. $188 \mathrm{I}$.

\section{D. -SOCIAL CONDITIONS.}

\section{(a) Classes of Society.}

2681. Abrahams, I. Jewish Life in the Middle Ages. 1896.

2682. Bateson, M. Medirval England. 1905.

2683. Bergman, C. G. Studier i Svensk Servitutsrätt. Upsala, 1909.

2684. Bonnemíre, E. Histoire de la Jacquerie. 1873. 2685. Bonvalot, E. Le tiers état d'après la charte de Beaumont et ses filiales. Paris, 1884 .

2686. Brownlow, W. R. Lectures on Slavery and Serfdom in Europe. 1892.

2687. BRUn, F. La vie privée des paysans au moyenâge. 1882 . 
2688. BRUTaIls, J. A. La condition des populations rurales du Roussillon au moyen-âge. Paris, 1891.

2689. Burton, J. H. The Scot Abroad. Edinburgh, I88I.

2690. Caggese, R. Classi e communi rurali nel medio evo italiano. Florence, 1907, etc.

2691. Carlyle, T. Past and Present. 1902.

2692. Cheyney, E. P. The disappearance of English Serfdom. English Historical Review, Vol. XV. I901.

2693. Cooke, A. M. The Settlement of the Cistercians in England. English Historical Review, Vol. VIII. 1893 .

2694. Cunningham, W. Alien Immigrants to England. Social England Series. 1897.

2695. Cutrs, E. L. Scenes and Characters of the Middle Ages. I9I I.

2696. Parish Priests and their People. 1898.

2697. Dalyell, J. G. The darker superstitions of Scotland. Glasgow, 1835 .

2698. Dareste, C. Histoire des classes agricoles en France depuis saint Louis jusqu'à Louis XIV. Paris, 1858.

2699. Delisle, L. La classe agricole en Normandie. 2700. Etudes sur la condition de la classe agricole et de l'état de l'agriculture en Normandie pendant le moyen-âge. Evreux, 1851 .

270I. Doniol, H. Histoire des classes agricoles de la France. I 857 .

2702. Estrup, H. F. J. Om Traeldom i Norden. Soroe, 1823 .

2703. ForESTrÉ, G. La vie rurale et l'agriculture au XIVe siècle dans le sud-ouest. 1886.

2704. Garnier,R.M. Annals of the British Peasantry. 1895.

2705. History of the English Landed Interest. 1892. 
2706. Gautier, Leon. La Chevalerie. I 884.

2707. Hanauer, C. A. Les paysans de l'Alsace au moyenâge. 1851 .

2708. Harris, M. D. Laurence Saunders, Citizen of Coventry. English Historical Revicw, Vol. IX. I894.

2709. Jacors, J. The Jews of Angevin England. (English History by Contemporary 'Writers' Series.) I893.

2710. - RyE, W., etc. Papers on Jewish History read at the Anglo-Jewish Historical Exhibition of 1887 . 1888 .

For titles of works dealing more especially with the financial aspect of the Jewry, see Nos. $214^{8}$ sq.

2711. Jessopp, A. The coming of the Friars and other essays. I 889 (I 888 ).

2712. Kemble, J. M. The Saxons in England. 1876. 2713. Law, A. English Nouveaux Riches of the 1 $4^{\text {th }}$ century. Trans. Royal Historical Society, N.S., IX. 1895 .

2714. Levasseur, E. Histoire des classes ouvrières en France depuis la conquête de J. César jusqu'à la Révolution. 1859.

2715. Litrle, A. G. Gesiths and Thegns. English Historical Review, Vol. IV. 1889.

2716. Luce, S. Histoire de la Jacqueric. 1859.

2717. Lysons, S. The Model Merchant of the Middle Ages, exemplified in the story of Whittington. 1860.

2718. Macnamara, N. C. Story of an Irish Sept. 1896.

2719. Massingberd, W. O. The Lincolnshire Sokemen. English Historical Revicw, Vol. XX. 1905.

2720. Michel, Francisque. Histoire des races maudites de la France et de l'Espagne. 1847.

2721. Mugnier, Françors. Les Savoyards en Angleterre au XIIle siècle. Chambéry, I 890 . 
2722. O'Leary, De L. England under Richard II. 1908.

2723. Page, T. W. The end of Villainage in England. Publications of the American Economic Association, 3 rd ser., Vol. I. 1900.

2724. Rights, Disabilities, and Usages of the Ancient English Peasantry. Law Magazine and Law Review, Vol. XII.. XIII., XIV., XV., and XVI. I862-64.

2725. Palgrave, Sir F. The Merchant and the Friar. I 844 .

2726. - The Lord and the Vassal: A familiar exposition of the Feudal System. I844.

2727 Perrens, F. T. La Démocratie au XIVe siècle. 1875.

2728. Powell, E. The Rising in East Anglia in $138 \mathrm{I}$. I 896.

2729. Pryce, G. Memorials of the Canynges' Family. 1854 .

2730. Pulling, A. The Order of the Coif. 1897.

2731. Réville, A., and Petir-Dutaillis, C. Le Soulèvement des Travailleurs d'Angleterre en I38I. 1898.

2732. Les paysans en France au XIIIe et au XIVe siècles. 1896.

2733. Rosières, R. Histoire de la Société Française au moyen âge. 1880 .

2734. Sainte-Palaye, LaCurne de J.B.de. Mémoires sur l'ancienne chevalerie (ed. Nodier). 1826. 2735. Sеввонм, F. Villainage in England. English Historical Review, Vol. VII. 1892.

2736. Selden, J. Titles of Honour. I672.

2737. Steenstrup, J. C. H. R. Der Danske Bonde og Friheden. Copenhagen, 1888.

2738. Trevelyan, G. M. England in the Age of Wycliffe. I909.

2739. Tuetey, A. Les écorcheurs sous Charles VII. Mont-béliard. 1874 . 
2740. Vinogradoff, P. G. English Socicty in the Eleventh Century. 1908.

2741. -Villainage in England. 1892 (1891).

2742. WrIGIT, T. On the Political Condition of the English Peasantry during the Middle Ages. Archaologia, Vol. XXX. 1844.

(b) Manners and Customs.

2743. Abram, A. Social England in the 15 th century. 1909.

2744. Adams, G. B. Civilisation during the Middle Ages. 1894 .

2745. AdDy, S. O. The Evolution of the English House. Social England Series. 1898.

2746. Amherst, A. (afterwards Cecil, E.). A history of Gardening in England. 1910.

2747. Apperson, G. L. Gleanings after Time. 1907. 2748. D'Avenal, Viscomte G. Découvertes d'histoire sociale I200-1910. 1910.

2749. Baring-Gould, S. Family Names and their Story. 1910.

2750. Baudrillart, H. L'Histoire du Luxe privé et public. I878-80.

2751. Beck, S. W. Gloves: their Annals and Associations. 1883 .

2752. Bickerdyke, J. (C. H. Cook). The Curiosities of Ale and Beer. 1886.

2753. Blount, T. Tenures of Land and Customs of Manors (W. C. Hazlitt). 1874-1909.

2754. Brand, J. Observations on popular antiquities, chiefly illustrating the origin of our Vulgar Customs (W. C. Hazlitt). 1905.

2755. Carlisle, N. Endowed Grammar Schools in England and Wales. 1818 .

2756. Chadwick, H. M. Studies on Anglo-Saxon Institutions. 1905.

2757. Chambers, E. K. The Medirval Stage. 1903. 
2758. Cheyney, E. P. Industrial and Social History of England. New York, I90I.

2759. Cornish, F. W. Chivalry. Social England Series. London, I901.

2760. Coulton, G. G. Chaucer and his England. 1908.

2761. Dale, E. National Life and Character in Early English Literature. 1907.

2762. Dasent, G. W. The Norsemen in Iceland. Oxford Essays. 1858.

2763. The Story of Burnt Njal. (Transl.) I86I. 2764. Denifle, H. Die Universitaten des Mittelalters bis 1400 . Berlin, 1885 .

2765. Denton, W. England in the 15th century. I 888.

2766. Dillon, H. A., Viscount. A MS. Collection of Ordinances of Chivalry of the 15 th century. Archaologia, Vol. LVII. 1900.

2767. Ditchfield, P. H. Old English Sports, Pastimes, and Customs. I89I.

2768. - The City Companies of London and their good works. 1904.

2769. Dyer, T. F. T. British Popular Customs. 1876.

2770. English Folk-lore. 1880.

2771. EDEN, F. M. The State of the Poor. 1797.

2772. EdGAR, J. History of Early Scottish Education. Edinburgh, 1893.

2773. Fitris, R. S. Sports and Pastimes of Scotland, historically illustrated. Paisley, I891.

2774. Franklin, A. La Vie Privée d'autrefois. I889, etc.

2775. Furnivall, F. G. Manners and Meals in Olden Time. Early English Text Soc. O.S., 32. 1868.

2776. Education in Early England. Some notes used as foreword to a collection of treatises on "Manners and Meals in the Olden Time" for the E.E.T.S. London, Bungay, 1867. 
2777. Furnivall, F. G. Caxton's Book of Curtesye. Early English Text Soc. Extra Series, III. 1868.

2778. Garreau, L. L'état social de la France au temps des croisades. 1899.

2779. Gasquet, F. A. Parish Life in Medizual England. 1906.

2780. - English Scholarship in the 13th century. Dublin Revicu, Vol. 123. 1898.

2781. Grose, F., and Astre, T. Antiquarian Repertory. I 807-9.

2782. GALY, C. La famille à l'époque mérovingienne. Paris, 1901.

2783. Grant, J. History of the Burgh and Parish Schools of Scotland. Edinburgh, 1876, etc.

2784. Grupp, G. Kultur der alten Kelten und Germanen. München, 1905 .

2785. Guibal, G. Histoire du sentiment national en France pendant la guerre de cent ans. Paris, 1875 .

2786. Gurzot, F. P. G. Histoire de la civilisation en France. 1857.

2787. Guthrie, E. E. Old Scottish Customs, local and general. 1885 .

2788. Hackwood, F. W. Old English Sports. 1907.

2789. - Inns, Ales, and Drinking Customs of Old England. I909.

2790. The Good Old Times. 1910.

2791. Hall, H. Court Life under the Plantagenets. I 890 .

2792. Harris, R. D. Life in an old English Town: A history of Coventry. 1898.

2793. Hartshorne, C. H. Illustrations of Domestic Manners during the Reign of Edward I. Fournal of the British Archaological Association, Vol. XVIII. I862.

2794. Hodgetts, J. F. Older England. (Second series.) 1884 .

See also under the Sections relating to the Church, Town, and Physical Features. 
2795. Hodgetts, J. F. The English in the Middle Ages. 1885 .

2796. Lectures on Anglo-Saxon Dress and Food and Dwellings. International Health $E_{x-}$ hibition Publications. 1884 .

2797. Houtte, H. van. Essai sur la Civilisation

Flamande au commencement du XIIe siècle. Louvain, 1898.

2798. Howitr, W. Rural Life in England. 1838.

2799. Hunter, J. Robin Hood. I 883.

2800. Jewitr, L. On Ancient Customs and Sports of the Counties of Derby and Nottingham. Fourn. of the British Archeological Assoc., Vol. VII. and VIII. I852-53.

2801. Jusserand, J. J. English Wayfaring Life in the Middle Ages (14th century). Transl. by L. Toulmin-Smith. 1892 .

2802. Les Sports. Paris, I901.

2803. Keyser, J. R. The Private Life of the Old Northmen. Transl. by M. R. Barnard. 1868. 2804. Kirby, T. F. Annals of Winchester College. 1892.

2805. KaUTSKy, K. Die Vorläufer des neueren Sozialismus. Die Geschichte des Sozialismus in Einzelndarstellungen (E. Bernstein, etc.) Stuttgart, I895.

2806. Kurth, G. Notger de Liège et la civilisation au Xe siècle. Paris, 1905 .

2807. Langlois, $\mathrm{C}_{\mathrm{H}}$. V. La Connaissance de la Nature et du monde au moyen âge. Paris, I9II.

2808. La Société française au XIIIe siècle, d'après dix romans d'aventure. Paris, 1904.

2809. - La Vie en France au moyen âge d'après quelques moralistes du temps. Paris, 1908.

28ro. LEACH, A. F. Early Yorkshire Schools. Yorkshire Archæological Society Record Series. 1899. 
28II. Lecoy de la Marcie, A. La Société au XIIIe sièclc. 1880 .

2812. LðнеR, F. V. Kulturgeschichte der Deutschen im Mittelalter. München, I 89 I-4.

2813. London, Festival of Empire : The Book of the Pageant (S. C. Lomas). I9II.

2814. Lyte, Sir H. C. Maxwell. A History of the University of Oxford. I 886.

281 5. Maguire, D. L. Historic Links. Igro.

2816. Mackinnon, J. Culture in Early Scotland. 1892.

2817. Maitland, S. R. The Dark Ages. 1889.

2818. Malcolm, J. P. Manners and Customs of London. I8I I.

2819. Martin, C. T. Some Chancery Proceedings of the $15^{\text {th }}$ century. Arch. LIX. 1904.

2820. Méray, A. La Vie au temps des cours d'amour. Paris, 1876.

2821. La Vie au temps des libres prêcheurs. Paris, $\mathbf{I} 860$.

2822. - La Vie au temps des trouverès. Paris, 1873 . 2823. Merryweather, F. S. Glimmerings in the Dark. I 850.

2824. Milis, C. The History of Chivalry. 1826.

2825. Moкe, H. G. Mocurs, Usages, Fêtes et Solennités des Belges. Brussels, 1863 .

2826. Molard. Esquisses de moeurs sénonaises aux XIVe et XVe siècles. 1895 .

2827. Montelius, O. Sveriges Hednatid samt Medeltid, 1060-1350. Stockholm, 1877.

2828. Kulturgeschichte Schwedens. Leipzig, 1906.

2829. Mullinger, J. B. The University of Cambridge. I873-1911.

2830. Old English Cookery. Quarterly Review, Jan. 1894.

2831. OlrIK, A. Nordisk Aandsliv i Vikingetid og tidlig Middelalder. Copenhagen, 1907. 
2832. Page, W. The Victoria History of the Counties of England. 1900, etc.

Chapters on Social and Economic History, Schools, etc.

2833. Pauli, R. Bilder aus alt England. Gotha, I 876. (Transl. Pictures of Old England, E. C. Otté). 1906. The New Universal Library.

2834. Perez-Pujol, E. Historia de las instituciones Sociales de la España Goda. Valencia, I896.

2835. Petit de Julleville, L. La Comedie et les mœurs en France au moyen âge. Paris, I 886. 2836. Pollard, A. W. English Miracle Plays, Moralities and Interludes. 1909.

2837. Quicherat, J. Histoire du costume en France. Paris, 1875 .

2838. Rands, W. B. Chaucer's England. I869.

2839. Rashdall, H. The Universities of Europe in the Middle Ages. I 895 .

2840. Redstone, V. B. Social Condition of England during the Wars of the Roses. Trans. Royal Hist. Soc., N.S., Vol. XVI. 1902.

284I. Rogers, J. E. T. A History of Agriculture and Prices in England. 1866-1902.

2842. Rowвотнам, J. F. The troubadours and courts of love. Social England Series. 1895.

2843. Schultz, A. Häusliches Leben der Europäischen Kulturvölker vom Mittelalter. München, 1903.

2844. Séré, F. et Lacroix, P. Le Moyen Age et la Renaissance. I848-51. (Transl. I874.)

2845. Sharp, T. A Dissertation on the Pageants anciently performed at Coventry. 1825 .

2846. Sмyтн, J. The Lives of the Berkeleys (ed. Sir J. Maclean). Gloucester, 1883-5. Bristol and Gloucestershire Archaological Society.

2847. Soane, G. Domestic Manners and Habits of the Anglo-Saxons. Fubilee edition of the Works of Alfred the Great.) 1852-53. (Vol. I.) 2848. Sparrow, W. S. Old England. 1908. 
2849. Steiniausen, G. v. Geschichte der deutschen Kultur. Leipzig und Wien, 1904.

2850. - Monographien zur deutschen Kulturgeschichte. I 899-1905.

2851. Stolze, J. Die Entstehung des Gästerechts in den deutschen Städten des Mittelalters. Dissertation Marburg. 1901.

2852. Strutr, J. A complete view of the Manners, Customs, Arms, Habits, etc., of the inhabitants of England. 1774-76.

2853. The Sports and Pastimes of the People of England. 1903.

2854. Stubss, W. Seventeen lectures on the study of Modern and Medirual History. 1900.

2855. Synge, M. B. Short history of Social Life in England. 1906.

2856. TAYLOR, H. O. The Classical Heritage of the Middle Ages. I 901 .

2857. Thrupp, J. The Anglo-Saxon Home. A history of the Domestic Institutions and Customs of England. I862.

2858. Traill, H. D. Social England. I894-97.

2859. Turner, C. J. R. A history of Vagrants and Vagrancy. 1887.

2860. Turner, Sharon. History of the AngloSaxons. Vol. III. 1852.

2861. Turner, T. H. Domestic Architecture in England. 1851-59.

2862. - Observations on the State of Horticulture in England in Early Times. Archaol. Fourn., Vol. V. 1848 .

2863. Veal, T. The Domestic Life of Berkeley Castle. Transactions of the Bristol and Gloucestershire Archoological Society, Vol. XIX. $1894-95$.

2864. Vaublanc, V. V. H. VTE. DE. La France au temps des croisades, ou recherches sur les moeurs et coûtumes des Français aux XIIe et XIIIe siècles. Paris, I 844-7. 
2865. Viollet-le-Duc, E. E. Dictionnaire raisonné du mobilier de l'époque Carlovingienne à la Renaissance. Paris, I 858-75.

2866. Virnich, TH. Corvey: Studien zur Geschichte der Stände im Mittelalter. Bonn, 1908.

2867. WADE, J. An account of the Public Charities in England and Wales. I828.

2868. WARD, A. W., and WAller, A. R. (edited by). The Cambridge History of English Literature. I907, etc.

2869. WARNER, R. Antiquitates culinariæ. I791.

2870. WeLsFord, J.W.W. The strength of England. I9IO.

287I. Willis, R., and Clarke, J. W. The Architectural History of the University of Cambridge. 1886 .

2872. Wright, T. Early Mysteries. 1838.

2873. - A history of Domestic Manners and Sentiments in England during the Middle Ages. 1862. 2874. Zimmer, H. Irish element in Mediæval Culture. I89I.

\section{(c) The Position of Women.}

2875. Boulting, W. Woman in Italy from the introduction of the chivalrous service of love. Igro. 2876. Bücher, C. Die Frauenfrage im Mittelalter. Tübingen, I 882 .

2877. Buckstaff, F. G. Married Women's Property in Anglo-Saxon and Anglo-Norman Law. American Acad. of Polit. and Soc. Science Annals, IV., 33-64. I893.

2878. Chapman, A. B. W., and M. W. The Status of Women under the English Law, 1066-1909. I909.

2879. Dixon, E. Craftswomen in the Livre des Métiers. Economic Fournal, V. 1895.

2880. Eckenstein, L. Women under Monasticism, 500-1 500. 1896. 
2881. Education of Women in the Middle Ages, Articles and correspondence on (J. E. G. de Montmorency, G. G. Coulton, and A. F. Leach). Fournal of Education. I909-Ir.

2882. Furnivall, F. J. Chaucer's Prioress, her Nun Chaplain and three Priests, illustrated from the Paper survey of St. Mary's Abbey, Winchester. Chaucer Society Series, II., 16. 1876.

2883. Gomme, G. L. Widowhood in Manorial Law. Archaol. Review, II., 184-97. 1888.

2884. Jourdain, A. L'éducation des femmes au moyen âge. Memoires de l'Acad. des Inscriptions, T. XXVIII. I874.

2885. Hentsch, A. A. De la littérature didactique du moyen âge s'adressant spécialement aux femmes. 1903.

2886. Hugo, T. Medirval Nunneries of the County of Somerset. 1867 .

2887. Morton, J. Ancren Riwle. Camden Soc. 1853. 2888. Lawrence, H. History of. Women in England to 1200.1843 .

2889. Mead, W. E. The Prologue of the Wife of Bath's Tale. Mod. Lang. Revicw. I905, ctc. 2890. Riley, H. T. Prefaces to Munimenta Gildhallæ Londoniensis (Liber Albus). Rolls Series, Vol. I. I 859, and Memorials of London, I 868. 289i. Rousselot, P. Histoire de l'éducation des femmes en France. Paris, I883.

2892. Shaw-Sparrow, W. Women painters of the world. From the time of Caterina Vigri, 1413-63, to Rosa Bonheur and the present day. 1905.

2893. Stopes, C. C. British Freewomen. Social Science Series. 1907.

2894. Weinhold, K. Die deutschen Frauen in dem Mittelalter. Wien, I 897.

2895. WRIGHT, T. The Homes of Other Days. I 871 . 2896. Womankind in Western Europe. 1869. 


\section{E.-PHYSICAL CONDITIONS.}

(a) Physical features and sports and industries relating thereto.

\section{I.-Forests.}

Histories.

2897. Baring, F. The making of the New Forest. Eng. Hist. Rev., XVI., 427. I901.

2898. Bazeley, M. L. The Forest of Dean in its relation with the Crown during the 12 th and I 3 th centuries. I9I . (Bristol and Glouc. Arch. Soc. Trans., Vol. XXXIII., pt. 2.)

2899. Berg, C. H. E. von. Geschichte der deutschen Wälder bis zum Schlusse des Mittelalters. Dresden, I871.

2900. Braine, A. The history of Kingswood Forest. I 891 .

2901. Cox, J. C. The Royal Forests of England. 1905. Antiquary's Books.

2902. Fisher, W. R. The Forest of Essex: its history, laws, administration, and ancient customs . . . 1887 .

2903. Kerry, C. History of the Peak Forest. Derby Arch. and Nat. Hist. Soc. Journ., XV., 67. I893.

2904. Newbigging, T. The history of the Forest of Rossendale. I 893 .

2905. Nicholls, H. G. The Forest of Dean. 1858. 2906. Percival, L. Historical inquiry concerning Forests and Forest Laws. I8II.

2907. Rawle, E. J. Annals of the ancient Royal Forest of Exmoor. I 893 .

2908. Reports of the Commissioners on the Woods, Forests, etc., of the Crown, 1787-1 793.

2909. Sharpe, Montagu. The Forests of Middlesex. 29io. Turton, R. B. The Honor and Forest of Pickering. North Riding Record Soc., N.S.: Vol. I. 1894 . 
2911. Yeatman, J. P. Lost history of Peak Forest. Journ. of Derb. Arch. and Nat. Hist. Soc., XIV., I6r. I 892 .

Perambulations and Laws.

2912. Hewlett, H. W. Perambulations of Forests in Wilts, 1300. Wilts Arch. and Nat. Hist. Mag. IV., 195. 1853.

2913. Kennetr, W. Perambulation of Bernwode Forest. 1818. Parochial Antiquities, I., 528. 2914. Leathes, P. H. Observations on a Charter of Exemption from the Forest Laws granted by Henry III. to Stephen de Segrave. Arch., XV., 209. 1806.

291 5. Liebermann, F. Ueber Pseudo-Cnuts constitutiones de foresta. Halle, 1894.

29I6. Maclean, J. (ed.) A perambulation of the Forest of Dene . . . Io Edw. I. Bristol and Glouc. Arch. Soc., XIV., 356. I889-90; $\mathrm{XV}$, 304-6. I890-I.

2917. Manwood, J. A brefe collection of the lawes of the Forest . . 1592.

29I8. Moore, S. A., and Birketr, P. Short history of the rights of common upon the Forest of Dartmoor and the commons of Devon. Report to Dartmoor Preservation Association. Plymouth, I 890 .

2919. Rowe, S. Perambulation of Dartmoor (J. B. Rowe). Exeter, 1902.

2920. Turner, G. J. Select pleas of the Forests. Selden Socicty, No. 13. 1901.

Hunting.

2921. Сиавот, A. J. F. DE. La chasse à travers les âges. 1898 .

2922. JesSe, G. R. Researches into the history of the British Dog. 1866.

2923. Mitchell, E. B. The Art and Practice of Hawking. 1903 . 
2924. Twicr, W. The art of Hunting; or Three Hunting MSS. (A. Dryden). Northampton, 1908.

\section{2.-Rivers and Marshes.}

Histories of Rivers, etc.

2925. Badeslade, $T$. The history of the ancient and present state of the navigation of the Port of King's Lyn . . . 1766.

2926. Cunningham, W. The Cambridgeshire Rivers. Journ. of Royal Geog. Soc., XXXV., 700. 1910.

2927. Dugdale, W. The history of imbanking and draining of divers fens and marshes. 1772.

2928. Forbes, U. A., and Ashford, W. H. R. Our Waterways : a history of inland navigation. 1906.

2929. Gray, A. On the Watercourse called Cambridge in relation to the River Cam and Cambridge Castle. Camb. Ant. Soc. Proc., N.S., III., 6r. I896, etc.

2930. Hillen, H. J. History of Borough of King's Lynn. Norwich, 1907. (Vol. II., 766-775.)

2931. Hingman, J. H. De Maas en de dijken van den Zuid-Hollandschen Waard in I421. Hague, I 885 .

2932. Miller, S. H., and Skertchly, S. B. J. The Fenland past and present. I878.

2933. Wells, S. History of drainage of great level of the fens called Bedford Level. I 828-30.

2934. Westerhoff, R. Twee Hoofdstukken uit de Geschiedenis van ons Dijkwezen. Groningen, I864.

2935. Wheeler, W. H. History of the fens of South Lincolnshire. Boston [1897].

Fisheries.

2936. Anders, J. von. Das Jagd und Fischereirecht. Innsbruck, I 884 . 
2937. Bernes, Dame Juliana. Treatyse of fysshynge wyth an angle, 1496 (T. Satchell). 1883 .

2938. Macpuerson, D. Annals of commerce, manufactures, fisheries, and navigation. 1805 . (Vol. I.)

2939. Macpherson, H. A. A history of Fowling, etc. 1897.

2940. Moore, S. A., and H. S. The history and law of Fisheries. 1903.

2941. Schiwappach, A. Grundriss der Forst-und Jagdgeschichte Deutschlands. Berlin, I883.

Mills.

2942. Bennett, R., and Elton, J. History of Cornmilling. 1898-1904.

2943. Delisle, L. Origin of Windmills in Normandy and England. Fourn. Arch. Assoc., VI., 403. 1851 .

2944. George, E. F. Notes on some probable traces of Roman fulling in Britain. Arch. LIX., 207. 1904.

2945. Hall, H. (ed.). Pipe Roll of the Bishopric of Winchester, I208-1209. 1903. (p. xxvii. Mills).

\section{3.-Mines.}

2946. Brand, J. History and Antiquities of Newcastle-upon-Tyne. 1789.

2947. Calvert, J. The Gold Rocks of Great Britain and Ireland. 1853.

2948. Cox, J. C. Mining Operations of the Romans in England and Wales. Arch. Fourn. LII., 25. 1895.

2949. The Laws and Customs of the miners in the Forest of Dean. 1687.

2950. Gilbert, D. History of Cornwall. I $83^{8}$. 
2951. Haverfield, F. Administration of Roman Mines (With a list of mines in Roman Britain). Chester Arch. and Hist. Soc. Fourn., N.S , IV., 80. 1892.

2952. Hinde, J. H. On the trade of Newcastle previous to the reign of Henry III. Memoirs of Nortbumberland (Arch.Inst.) I, 24. 1858.

2953. Hunt, R. British Mining. I 887.

2954. Lapsley, G. T. Account Roll of a 15 th century ironmaster. Eng. Hist. Rev. XIV., 509. I899.

2955. Lewis, G. R. The Stannaries; a study of the Mediæval Tin Miner. (Harvard Economic Studies, III.) Igo8.

2956. Maclean, J. Stannary roll. 34 Edward I. (1305-6) with introductory remarks thereon and on other similar rolls. Fourn. of Royal Inst. of Cornwall, III., 238. I 868-70.

2957. Nicholls, H. G. Iron making in the olden times as instanced in the . . . Forest of Dean. I 866.

2958. Pearce, T. The Laws and Customs of the Stannaries in the Counties of Cornwall and Devon. 1725.

2959. SmiRke, E. Indenture under which the Silver Mines of Byrland (co. Devon) were worked temp. Edw. I. Arch.Fourn. XXVII. I 29. 1870. 2960. TAYLOR, T. J. Archæology of the coal trade. Memoirs of Nortbumberland (Arch. Inst.) I, I50. 1858 .

2961. Wright, T. Roman Mining Operations in Shropshire and North Wales. Sbrops. Arch. and Fat. Hist. Soc. XI., 272. 1888.

(b) Means of Communication.

Roads.

2962. Beloe, E. M. On the Great Fen Road and its path to the sea. Proc. of Camb. Ant. Soc., VII., N.S., I., p. II 2. 
2963. Beroe, E. M. The Padder's Way and its attendant roads. Proc. of Camb. Ant. Soc., IX., N.S., III., 77.

2964. Brown, P. Hume. Early Travellers in Scotland (from r 295.) 1891 .

2965. Codrington, T. Roman roads in Britain. 1905. 2966. Forbes, U. A., and Burmester, A. C. Our Roman Highways. 1904.

2967. KnUlu, B. Historische Geographie Deutschlands im Mittelalter. Breslau, 1903.

2968. Rauers, FR. Zur Geschichte der alten Handelsstrassen in Deutschland. Petermann's Mitteilungen aus Perthes geographischer Anstalt. 1906. Gotha.

2969. Rimmer, A. Ancient Streets and Homesteads of England. 1877 .

See also F. Haverfield in Cambridge Medizval History, Vol. I.

Bridges.

2970. Ferguson, C. R. S. Ancient and County

Bridges in Cumberland and Westmorland, with some remarks upon the fords. Trans. of Cumb. and Westmorland Ant. and Arch. Soc., XV., I I4. 1899.

2971. Harrison, W. Ancient Fords, Ferries, and Bridges in Lancashire. Trans. of Lanc. and Ches. Antiq. Soc., XII., I ; XIII., 74 ; XIV.. 67. $1894-96$.

2972. KERRY, C. Hermits, Fords, and Bridge Chapels. Derb. Arch. and Nat. Hist. Soc., XIV., 54. 1892 .

2973. Kershaw, S. W. Ancient Bridge Chapels. St. Paul's Eccles. Soc., I., 203-9. $1881-5$.

2974. - Account of Lechlade Bridge, Gloucestershire. Coll. Top. et Gen., I., 320. 1834.

2975. Sharpe, M. The great Ford across the Lower Thames. 1906. (Reprinted from Arch. Fourn., LXIII., No. 249, p. 25.) 
2976. Shropshire County Records, No. 3. Plans and Documents relating to Roads, Bridges, etc. 1902.

2977. Worth, R. N. Calendar of Tavistock Parish Records. I 887.

\section{(c) Public Health and Population.}

2978. Clay, R. M. Mediæval Hospitals of England. 1909. Antiquary's Books.

2979. Creighton, C. A history of epidemics in Britain from A.D. 664 to the extinction of plagues. Cambridge, I891.

2980. Curschmann, F. Hungersnöte im Mittelalter. Leipzig, 1900. Arndt's Leipziger Studien.

2981. Gaseuet, F. A. The Black Death of 1348 and I349. 1908.

2982. Hecker, J. F.C. Epidemics of the Middle Ages. (Transl. 1844.) Sydenham Society.

2983. Hoeniger, R. Der Schwarze Tod in Deutschland. Berlin, I882.

2984. Jastrow, J. Die Volkzahl deutscher Städte zu Ende des Mittelalters und zu Beginn der Neuzeit. Berlin, 1886. Historische Untersuchungen. Hft. I.

2985. Moore, N. The history of the Study of Medicine in the British Isles. Oxford, I908.

2986. Neuburger, M. History of Medicine (transl. E. Playfair). Vol. I. 1910. (Section iv.: Medicine in the Middle Ages.)

2987. Payne, J. F. English medicine in the AngloSaxon times. 1904.

2988. Puschmann, T., Neuburger, M., and Payel, J. Handbuch der Geschichte der Medizin. Jena, I90I-5.

2989. South, J., and Power, D'Arcy. Memorials of the Craft of Surgery. I 886. 


\section{F.-ECONOMIC THOUGHT.}

2990. Asuley, W. J. An Introduction to English Economic History and Theory. Pt. I., I894; Pt. II., 1906.

2991. Baumann, J. J. Die Staatslehre des h. Thomas von Aquino. Leipzig, 1909.

2992. Bensa, E. Il Contratto di Assicurazione nel Medio Evo. Genoa, I884.

2993. Brants, V. L'économie politique au moyenâge. Esquisse des théories économiques professées par les écrivains des XIIIe et XIVe siècles. Louvain, etc., 1895 .

2994. BridRey, E. La Théorie de la monnaie au XIVe siècle. Nicole Oresme. Etude d'histoire des doctrines et des faits économiques. Paris, 1906.

2995. BRUder, A. Zur ökonomischen Charakteristik des römischen Rechtes. III. Stellung der kanonistischen Periode zum reinen und zum späteren römischen Recht. Zeitschrift für die gesammte Staatswissenschaft XXXIII., pp. 684-724. Tübingen, 1877.

2996. Carlyle, R. W., and A. J. History of Medixval Political Theory in the West. 1903-9.

2997. Conigliani, C. A. Saggi di Economia Politica e di Scienza delle Finanze. Turin, etc., 1903. pp. 263-288, Le dottine monetarie in Francia durante il medioevo.

2998. Contzen, H. Geschichte der Volkswirthschaftlichen Literatur im Mittelalter. Berlin, 1872. 2999. Cossa, L. Introduzione allo Studio dell' Economia Politica. Milan, 1892. (Transl. by L. Dyer as An Introduction to the study of Political Economy, 1893.)

3000. Cunningham, W. Christian Opinion on Usury. 1884 .

See also No. 829 .

3001. Cusumano, V. Saggi di Economia Politica e di Scienza delle Finanze. Palermo, 1887. 
3002. Dunning, W.A. A history of Political Theories, Ancient and Mediæval. New York, etc., 1902.

3003. Ehrle, F. Beiträge zur Geschichte und Reform der Armenpllege. Freiburg im Breisgau, I 88I.

3004. Endemann, W. Die nationalökonomischen Grundsätze der canonistischen Lehre. Jena, I 863 .

3005. Studien in der romanisch-kanonistischen Wirthschafts- und Rechtslehre. Berlin, I $874-83$.

3006. Espinas, A. Histoire des Doctrines Economiques. Paris [1892].

3007. Fornari, T. Delle teorie economiche nelle provincie Napolitane dal secolo XIII. Milan, I 882 .

3008. Funk, F. X. Zins und Wucher. Tübingen, I 868 .

3009. Ueber die ökonomischen Anschauungen der mittelalterlichen Theologen. Zeitschrift für die gesammte Staatswissenschaft, XXV., pp. 1 25-175. Tübingen, I 869.

3010. Geschichte des kirchlichen Zinsverbotes. Tübingen, I 876 .

30II. Gierke, O. Political Theories of the Middle Age (transl. with introduction by $F$. W. Maitland). Cambridge, I900.

3012. Goldschmid, L. Handbuch des Handelsrechts. Stuttgart, I89I.

30r3. Hahl, A. Zur Geschichte der volkswirtschaftlichen Ideen in England gegen Ausgang des Mittelalters. Staatswissenschaftliche Studien, V. Bd., pp. IоI-I6o. Jena, I 896.

3014. Hazeltine, H. D. Die Geschichte des englischen Pfandrechts. Breslau, I907. Untersuchungen zur Deutschen Staats und Rechtsgeschichte. Hft. 92. 
301 5. Hazeltine, H. D. The Gage of Land in Medieval

England. Harvard Law Reviow, XVII., 8; and XVIII., 1. 1904.

3016. Hertrich, H. Les Théories monétaires au

XIVe Siècle. Nicolas Oresme. Lyons, 1899.

3017. IlgneR, C. Die volkswirtschaftlichen Anschauungen Antonins von Florenz, 1389-1459. Ergänzungsheft VIII. zum Fahrbuch für Philosophie und spekulative Theologie. Paderborn, 1904.

3018. Janssen, J. Geschichte des deutschen Volkes seit dem Ausgang des Mittelalters. (Vol. I., 3 rd Book.) Freiburg im Breisgau, 1890. (Transl. by M. A. Mitchell and A. M. Christie, I 896.)

3019. Jenks, E. Law and Politics in the Middle Ages. 1898.

3020. Jourdain, C. Mémoire sur les commencements de l'économie politique dans les écoles du moyen âge. Excursions historiques, et philosophiques à travers le moyen âge, pp. 42I-462. Paris, 1888.

3021. Lallemand, L. Histoire de la Charité. Vols. II. and III. Paris, 1903-6.

3022. Latres, A. Il diritto commerciale nella legislazione statutaria delle città italiane. Milan, 1884 .

3023. - Il diritto consuctudinario delle città lombarde. Milan, 1899 .

3024. Nys, E. Researches in the History of Economics. (Transl. by N. F. and A. R. Dryhurst). 1899.

3025. Poole, R. L. Illustrations of the History of Mediaval Thought. I 884 .

3026. Rambaud, J. Histoire des doctrines économiques. Paris, 1899. (Ch. ii., pp. 17-47: Le moyen âge.) 
3027. Ratzinger, Georg. Geschichte der kirchlichen Armenpflege. Freiburg im Breisgau, I894.

3028. Schulte, J. F. von. Geschichte der Quellen und Literatur des Canonischen Rechts. Stuttgart, I 875-80.

3029. Sñberschmidt, W. Die Commenda in ihrer frühesten Entwicklung bis zum XIII. Jahrhundert. Würzburg, I 884 .

3030. TAYlor, H. O. The Medirval Mind : A history of the Development of Thought and Emotion in the Middle Ages. I9II.

303 I: Uhlhorn, G. Die christliche Liebesthätigkeit. Stuttgart, I 882-90.

3032. Weber, M. Zur Geschichte der Handelsgesellschaften im Mittelalter. Nach südeuropäischen Quellen. Stuttgart, I889.

3033. Wolowski, M. L. Introduction, etc., to "Traictie de la première invention des Monnoies" de N. Oresme. Paris, 1864. 


\section{APPENDIX A.*}

Select List of British Learned Societies, whose

Publications contain materials for Medicval

Economic History.

(a) Central.

\section{England.}

3034. Anglia Christiana Society. Publications. 1 846-8. (Extinct.)

3035. Society of Antiquaries of London. Archæologia, 1770, etc. Vetusta Monumenta, 1747-1895.

Publications and Proceedings, 1849 , etc.

3036. Associated Architectural Societies. Reports and Papers, $185 \mathrm{I}$, etc.

3037. British Academy Proceedings. 1905, etc.

3038. British Archrological Association. Journal,

1845, etc. Collectanea Archæologia, 1861, ctc. 3039. British Record Society: Publications. I 890 , etc. (In 1890 this Society absorbed the Index Library, London, 1888, and the Index Society.)

3040. British Society of Franciscan Studies. Publications. 1908.

3041. Camden Society. Publications (O.S. and N.S.). 1838, etc. (In 1897 the Publications of the Camden Society became the Camden Series of the Royal Historical Society.)

3042. Canterbury and York Socicty. Publications. 1907 , etc.

3043. Caxton Society. Publications. 1844-54. 3044. Chaucer Society. Publications. 1868, etc.

- A similar list was prepared for Continental Staces, but this has beed lound too long to print. 
3045. Early English Text Society. Publications. I864, etc.

3046. Folk-lore Society. Folk-lore Record, 1878,

5 vols., cont. as Folk-lore Journal, I $883-89$,

7 vols., cont. as Folk-lore, 1890, etc.

3047. Henry Bradshaw Society. Publications. I891, etc.

3048. Jewish Historical Society. Transactions. I895, etc.

3049. Manorial Society. Publications. 1907, etc. 3050. British Numismatic Society. Journal and Proceedings. 1905, etc.

3051. Royal Numismatic Society. Numismatic Journal, Numismatic Chronicle, etc. 1837, etc. 3052. Percy Society. Publications. I84I, etc. 3053. Pipe Roll Society. Publications. 1884, etc. 3054. Roxburghe Club. Publications. 1814, etc. 3055. Royal Archæological Institute of Great Britain and Ireland. Archæological Journal. 1845, etc.

3056. Royal Historical Society. Transactions and Publications. I875, etc.

3057. Royal Society of Literature of the United Kingdom. Transactions, 1829-39.

3058. Selden Society. Publications. I888, etc.

(b) Local.

3059. Berkshire. Berkshire Archæological and Architectural Society (formerly Berkshire Ashmolean Society). Quarterly Journal, I889-I 895. I87I, etc.

3060. Buckinghamshire. Architectural and Archæological Society for the County of Buckingham. Aylesbury, I858, etc.

306I. Cambridgeshire. Cambridge Antiquarian Society. Cambridge, I 859, etc.

3062. Cambridge and Huntingdon Archæological Society. Transactions. Ely, 1901, etc. 
3063. Cheshire (see also Lancashire). Chester Archxological and Historic Society, formerly Architectural, Archrological and Historic Society of Chester. Journal. Chester, 1849-85, etc. New Series, 1887 , etc.

3064. Cumberland (see Westmorland). Cumberland and Westmorland Antiquarian and Archrological Society. Transactions. Kendal, I874, etc.

3065. Derbyshire. Derbyshire Archxological and Natural History Society. Journal. London and Derby, 1879 , etc.

3066. Devonshire. Devonshire Association for the Advancement of Science, Literature, and Art. Transactions. Plymouth, 1863 , etc.

3067. Devon and Cornwall Record Society. Exeter, 1905, etc.

3068. Dorsetshire. Dorset Natural History and Antiquarian Field Club. Proceedings. Sherborne, 1877 , etc.

3069. Durham. Sunderland Antiquarian Society. Transactions. Sunderland, 1902, etc.

3070. Surtees Society. Publications. Newcastle, 1835 , etc.

3071. Essex. Essex Archrological Society. Transactions. Colchester, 1858, etc.

3072. Gloucestershire. Bristol and Gloucestershire Archæological Society. Transactions. Bristol, 1876, etc.

3073. Clifton Antiquarian Club. Procecdings. Bristol, I886, etc.

3074. Hampsure. Hampshire Record Society. Publications. 1889, etc.

3075. - Southampton Record Society. Publications. Southampton, 1905, etc.

3076. Hereford. Cantilupe Society. Hereford. 1906, etc. 


\section{A SELECT BIBLIOGRAPHY OF}

3077. Hertfordshire. East Herts Archæological Society. Transactions. Hertford, 1900, etc.

3078. - St. Albans Architectural and Archæological Society. Transactions. 1885 , etc.

3079. - Herts Genealogist and Antiquary. Harpenden, r895, etc.

3080. Kent. Kent Archæological Society. Archæologia Cantiana: I858, etc.

3081. - Lewisham Antiquarian Society. Proceedings. Lee, 1887 , etc.

3082. Lancashire (see also Cheshire). Chetham Society. Publications. Manchester, 1844 , etc. 3083. - Historic Society of Lancashire and Cheshire. Proceedings. Liverpool, 1849 , etc.

3084. Lancashire and Cheshire Antiquarian Society. Transactions. Manchester, 1884 , etc. 3085. Record Society for Lancashire and Cheshire. Publications. I 875 , etc.

3086. Leicestershire. Leicestershire Architectural and Archæological Society. Transactions. Leicester, I866, etc.

3087. Lincolnshire. Lincolnshire Record Society. Publications. Horncastle, I89I, etc.

3088. Middlesex. London and Middlesex Archæological Society. Transactions. I 856, etc.

3089. Norfolk. Norfolk and Norwich Archæological Society. Journal. Norwich, I847, etc.

309o. Northumberland. Society of Antiquaries, Newcastle-on-Tyne. Archæologia Eliana. Newcastle, I822, etc.

3091. Nottinghamshire. Thoroton Society. Transactions. Nottingham, 1898 , etc.

3092. Oxfordshire. The Oxfordshire Archæological Society (since 1888). Transactions. Formerly North Oxfordshire Archæological Society. Publications. Oxford, 1856, etc.

3093. Oxford Historical Society. Publications, Oxford, i885, etc. 
3094. ShropshiRe. Shropshire Archrological and Natural History Society. Transactions. Shrewsbury, 1877 , etc.

3095. Somersetsuree. Somersetshire Archæological and Natural History Socicty. Proceedings. Taunton, $185 \mathrm{I}$, etc.

3096. - Somerset Record Society. Publications. 1887 , etc.

3097. Staffordsure. The William Salt Archæological Society. Publications. Birmingham, 1880 , etc. 3098. Suffolk. Suffolk Institute of Archæology and Natural History. Proceedings. Bury St. Edmunds, I\$49, etc.

3099. Surrey. Surrey Archæological Society. Archæological Collection. 1858, etc.

3100. Sussex. Sussex Archæological Society. Archæological Collection. 1848 , etc.

3101. Sussex Record Society. Publications. I902, etc.

3102. Warwickshire. Warwick Historical and Archæological Society. Proceedings. Warwick, $1837-80$.

3ro3. Westmorland (see Cumberland). Cumberland and Westmorland Antiquarian and Archæological Society. Transactions. Kendal, 1874, etc. Extra series, London, 1877.

3104. Wiltshire. Wiltshire Archrological and Natural History Socicty. Magazine. Devizes, 1854 , etc.

3105. Wilts Record Society. Publications. Salisbury, I896, etc.

3106. Worcestershire. Worcestershire Historical Society. Publications. Oxford, 1893, etc.

3107. Yorkshire. Yorkshire Archæological Society (1893), formerly Yorkshire Archæological and Topographical Association. Journal, 1870-91. 1870 , etc. 
278 A SELECT BIBLIOGRAPHY OF

3108. - Bradford Historical and Antiquarian Society. Bradford, 1881, etc.

3109. Yorkshire. East Riding Antiquarian Society. Transactions. Hull, I893, etc.

31 10. - North Riding Record Society. Publications. I 884-97.

3III. Thoresby Society. Publications. Leeds, I889, etc.

\section{Scotland.}

3112. Abbotsford Club. Publications. Edinburgh, I835-66.

3113. Aberdeen Ecclesiological Society. Publications. Aberdeen, I887-1905.

3II4. Ayrshire and Galloway Archæological Association (Ayrshire and Wigtonshire Archæological Association). Ayr, I878-99, I897.

3II5. Banffshire Field Club. Transactions. Banff, I 880 , etc.

3II6. Bannatyne Club. Publications. Edinburgh, I823; dissolved in 1861.

3117. Berwickshire Naturalists Club. Publications. Alnwick, I887, etc.

31 18. Buchan Field Club. Transactions. Peterhead, I 887 , etc.

3I19. Dumfriesshire and Galloway Natural History and Antiquarian Society. Transactions and Journal. Dumfries, I 864 , etc.

3120. Glasgow Archæological Society. Transactions. Glasgow, 1 859-83.

3I2I. - Ecclesiological Society (see Scottish Ecclesiological Society). Glasgow.

3122. Grampian Club. Publications. 1872. (The Club ceased to publish since I 89I.)

3123. Hawick Archæological Society. Transactions. Hawick, 1906, etc.

3124. Inverness Scientific Society and Field Club. Transactions. Inverness, 1898 , etc. 
3125. Iona Club (one vol. only published). Edinburgh, 1839.

3126. Maitland Club. Publications. (No vols. issued since I859.) Glasgow, I829.

3127. New Club. Paisley, 1877, etc.

3128. New Spalding Club. Publications. Aberdeen, I889, etc.

3129. Royal Philosophical Society of Glasgow. Historical and Philological Section, 1902, etc.

3130. Scottish Burgh Records Society. Publications. Edinburgh, 1869-82. Dissolved in 1908.

3131. Ecclesiological Society. Aberdeen, 1903. (On the union of the Aberdeen and Glasgow Ecclesiological Society.)

3132. - History Society. Publications. Edinburgh, I887, etc.

3133. - Text Society. Publications. Edinburgh, 1884 , etc.

3134. Spalding Club. Publications. Aberdeen, 18391870.

3135. Spottiswode Society. Edinburgh, 1844. (The Society has not published since 185I.)

3136. Stirling Natural History and Archæological Society. (Stirling Field Club). Publications. Stirling, 1878 , etc.

3137. Viking Club, or Orkney, Shetland, and Northern Society. Proceedings. 1892, etc.

3138. Orkney and Shetland Old Lore Series of the Viking Club. 1907, etc.

\section{Ireland.}

3139. Cork Historical and Archrological Society. Journal. Cork, I893, etc.

3140. Co. Kildare Archæological Society. Journal. Dublin, 1895, etc.

3141. Kilkenny Archæological Society. Dublin, 1853, etc. 
3142. Irish Archæological Society (Irish Archæological and Celtic Society). Tracts. Dublin, I84I, etc.

3143. Royal Society of Antiquaries of Ireland.

3144. Royal Irish Academy. Transactions. Dublin, I 788, etc.

\section{Wales.}

3145. Cambrian Archæological Association. Archæologia Cambrensis. I846, etc.

3146. Cambrian Institute. The Cambrian Journal, London, I 854-64.

3147. Honourable Society of Cymmrodorion. Magazine, Transactions, and Publications. I877, etc.

3148. Powysland Club. Collections, Historical and Archæological, relating to Montgomeryshire. I 868, etc.

3149. Society for Publication of Welsh MSS. Llandovery, I 840 , etc.

\section{Channel Islands.}

3150. Isle of Man. Manx Society. Publications. Douglas, 1859 , etc.

3I5I. Jersey. Société Jersiaise. Publications. St. Helier's, I876, etc.

\section{America.}

3152. Columbia College. Studies in History, Economics, and Public Law. New York, I891, etc.

3153. Harvard University. Harvard Historical Studies. New York, I 896, etc.

3154. Johns Hopkins University. Studies in History and Political Science. Baltimore, I882, etc.

3155. Pennsylvania University. Philadelphia, Department of History, I897, etc.

3156. Radcliffe College. Monographs. Boston, I894, etc. 


\section{APPENDIX B.}

Select List of British and American Periodical Publications containing contributions to Mediaval Economic History.

Central.

\section{England.}

3157. Ancestor. 1902-5.

3158. Antiquary. 1880, etc.

3159. Antiquarian Magazine and Bibliographer I $881-87$.

3160. Antiquary's Magazine. 1807.

3161. Archæological Review. 1888-90.

3162. Athenxum. 1823, etc.

3163. British Magazine and Monthly Register. 1832-49.

3164. Economic Journal. 1891, etc.

3165. English Historical Review. 1886, etc.

3166. Folk-lore (published by the Folk-lore Society). 1890 , etc.

3167. Gentleman's Magazine. 1731, etc.

3168. Law Quarterly Review. I885, etc.

3169. Notes and Queries. I850, etc.

3170. The Reliquary. 1860, etc. (In I 895 the title was changed to the "Reliquary and Illustrated Archæologist.”)

Local.

3171. Cheshire. Notes and Queries. Stockport, 1886 , etc.

3172. Derby. See Notts.

3173. Devon. Notes and Gleanings, I888-92.

3174. - Notes and Queries. Exeter, 1900, etc.

31 75. Western Antiquary, or Devon and Cornwall Note Book. Plymouth, 188I-1893. 
3176. Dorset. See Somerset.

3177. East Anglian Notes and Queries for Suffolk, Cambs, Essex, Norfolk. Lowestoft, I 858, etc. 3178. Gloucestershire. Notes and Queries. I879, etc.

3179. Hampshire. Hampshire Antiquary and Naturalist ; Notes and Queries of Hampshire Field Club. Southampton, I891.

3180. Home Counties' Magazine. I899, etc. (See Middlesex and Herts Notes and Queries.) 3181. Huntingdon. Fenland Notes and Queries. Peterborough, I889, etc.

3182. Leicestershire and Rutland. Notes and Queries. Leicester, I89I, etc.

3183. Lincolnshire. Notes and Queries. Horncastle, I889, etc.

3184. Middlesex and Herts. Notes and Queries. I895, etc. (Home Counties' Magazine, since 1898.)

3185. Midland Antiquary. Birmingham, I882-I887. 3186. Northamptonshire. Notes and Queries.

Northampton, 1894.

3187. Northumberland. Northern Notes and Queries. January, 1906, to October, 1907, only.

3188. Notts and Derbyshire. Notes and Queries. I 892-8.

3189. Rutland. See Leicester.

3I9o. Shropshire. Notes and Queries. Shrewsbury, I886-7.

319I. Notes and Queries for Somerset and Dorset. Sherborne, I888, etc.

3192. Wiltshire. Notes and Queries. 1893, etc.

3193. Yorkshire. Yorkshire Notes and Queries, etc. Bradford, 1885-90. (After October, I890, the work was incorporated with the "Yorkshire County Magazine.”) 
MEDIÆVAL ECONOMIC HISTORY 283

\section{Scotland.}

3194. Northern Notes and Queries. Edinburgh, 1888-90. (Continued as Scottish Antiquary. Edinburgh, 1890-1903. Continued as Scottish Historical Review, 1903, etc.)

\section{Wales.}

3195. Byegones relating to Wales and the Border Counties. Oswestry, 1871, etc.

3196. Caermarthenshire Notes. Llanelly, 1889, etc. (Called, since 1892, Caermarthenshire Miscellany and Notes and Qucries for SouthWest Wales.)

\section{America.}

3197. American Historical Review. New York, 1895, etc.

3198. Harvard Quarterly Journal of Economics. Boston, Mass. 1887, etc.

3199. Political Science Quarterly. New York, 1886 etc. 


\section{INDEX}

Abbadie, F. Le Livre Noir, No. 1458.

Abbreviations, p. 53 .

Aberdeen, No. 2454.

- Council Register, No. 1289.

- Inventories of Records, No. 297.

Registrum Episcopatus Aberdonensis, No. 1266.

Abert, J. F. Archivalische Literatur, No. 193.

Abingdon, No. 2406.

— Abbey Accounts, No. 1148. Chronicle, No. I 78 .

Abjuratio regni, No. 1927.

Aboensis Ecclesiæe Registrum, No. 1660 .

Abrahams, I. Jewish Life, No. 2681.

Abram, A. Social England, No. 2743.

Abram, W. A. Preston Guilds, No. 2453 .

Accountants, No. 2485 .

Accounting, No. 2485 .

Accounts, pp.99-105, 118-122, 734, Nos. $1335,1977$.

— Empire, pp. 169-170.

- France, pp. 157-9.

- Low Countries, p. 165.

Ackworth, No. 2139.

Acton, J. E. E. D. [Baron]. Bibliography of. No. I 44 .

- Study of History, No. 359 .

Acts, Royal, France, pp. 159-6o.

Adams, G. B. Anglo-Saxon

Feudalism, Nos. 1686, 2196.

- Civilisation, No. 2744.

- Political History of England, Nos. 815,1728 .

Adams, H. Anglo-Saxon Courts of Law, No. I874.

Adams, J. Index Villaris, No. 722.

Addison, C. G. Knights Templars, No. 2106.

Addy, S. O. Beauchief Abbey, No. 2626.

- English House, Nos. 594, 2745 .
Adkin, B. W. Copyhold, No. 1875 .

Admiralty Court, Select Pleas, No. Iogo.

Admiralty, Greenwich Hospital Department, p. 94.

Advocates' Library. See Edinburgh.

Aelfric's Colloquy, No. 1224.

Agen, Archives Municipales, No. $173^{\text {nt. }}$

Comptes d', No. 1399.

Agincourt Roll, No. 1842 .

Agrarian Economy, pp. 83, 22 I-6.

Agrarian History. Bibliographies, Nos. $130,138,147$.

Works. See Manor.

Agricultural Classes, No. 2698, 2699, $2700,2701$.

Agricultural Services, No. 2268.

Agriculture, Nos. 2700, 2703, 284 I.

Aids, Nos. 97 7 , 978. See Feudal Aids.

Aitken, P. H. Catalogue of MSS. in Hunterian Museum, No. 298.

Akermann, J. Y. Malmesbury Rent Roll, No. II73.

Albe, E. Marchands de Cahors, No. 1997.

Albi, Comptes d'. No. 1400.

Alcubilla, M. Diccionario, p. 27.

Ale, Nos. 2752, 2789.

Alfred the Great, No. 1717.

Alien Immigrants, No. 2694.

Alien Merchants. See Merchants.

Allcroft, A. H. Earthworks, No. 601.

Allen, C. F. Denmark, No. 8ro.

Allen, G. Anglo-Saxon Britain, No. 1687 .

Allen, J. Royal Prerogative, No. 2197.

Allen, J. R. Celtic Art, No. 6r 1.

Allen, W. F. Essays, No. 2119.

Almonbury, No. 2189.

Alnwick, No. 2407.

Alrewas Court Rolls, No. 1198.

Alsace, No. 2707. 
Altamira y Crevea, R. De His. toria y Arte, No. 218.

- Historia de Eispana, No. 806.

Altmann, W. Urkunden, No. 1544.

Ambassadors of Hamburg in Avignon. No. 1553.

America, Scriptores Septentrionalis rerum ante-Columbianarum in, No. 1664 .

American Historical Review, No. 81.

Amherst, A. (afterwards Cecil, E.). Cardening, No. 2746 .

Amira, K. von. Eirbenfolge, No. 2108.

Amphlett, J. Hales Court Rolls, No. 1207.

Analecta Anglo-Saxonica. No. 1224.

Ancient Deeds, No. 923.

Ancient Demesne, No. 2275.

Ancren Riwle, No. 1225.

Anders, J. von. Das Jagd und Fischereirecht, No. 2936.

Anderson, J. Calendar of Laing Charters, No. 1264.

- Thesaurus, No. $4^{83}$.

Anderson, J. P. British Topography, No. 73 .

Anderson, P. J. Inventories of Aberdeen Records, No. 297.

Andrews, C. M. Old English Manor, No. 2120.

Andrews, E. A. What is History? No. 368.

Andrews, E. B. Principles of History, No. 363 .

Angers, Cartulaire de l'abbaye de Saint Aubin d', No. 1370.

Angers, Cartulaire noir de la cathédrale d', No. 1368 .

Anglo-American legal History, No. 820.

Anglo-Norman Pleas, No. 1056.

Anglo-Saxon Courts of Law, Nos. 1874. 1941.

- Institutions, No. 2756.

Landbook, No. 2126.

I.and law, No. 1904.

Law's, Nos. 1051, 1052. 1929.

Manuscripts, No. 1100.

Anglo-Saxons, Nos. 1686, 1687 , 1691, $2121,2128,2196,2335$. $2796,2847,2857,2860,2987$.
Anisy, 1. d'. Roles Normands, No. 872 .

Anjou, No. 1446.

Annerstedt, C. Scriptores, No. 1676.

Annuaire des Bibliotheques, No. 176.

Anscombe, $\Lambda$. Anglo-Saxon Computation, No. 514.

Ansell, G. F. Royal Mint, No. 1800 .

Anson, W. R. Law of the Constitution. No. 1843.

Antiquaries, Society of. See L.ondon.

Antiquities, pp. 59-60.

Catalogues and Guides of, in Museums, pp. $4^{t-3}$.

Antonin von Florenz, No. 3017.

Apperson, G. L. Gleanings, No. 2747.

Aquinas, Thomas, No. 2991.

Arabs, Nos. 1379, 2029.

Aragon, No. 1640.

Arbois de Jubainville, H. D. Celtes, Nos. $1688,1689$.

Arbroath. Liber S. Thome de Aberbrothoc, No. 1253.

Archaologia, Index to, No. 58.

Archaoological Journal, Index to, No. 57 .

Archaoology, pp. 59-65.

- Bibliographies of, pp. 7-8.

Archbold, W. A. J. Teaching of History, Nos. 361, 506.

Somerset Religious Houses, No. 1942.

Archers, No. 1822.

Archery, No. 622.

Architecture, pp. 60-62, No. 2861.

- Bibliographies of, Nos. 63. 67.

Archivalische Zeitschrift, No. 202.

Archives Départementales, Nos. $171,172,173,301$.

Archives des Missions, pp. 20, 27.

Archives, History and Science of, No. 367 .

_- Inventories of, p. 16.

Archives Nutionales, Nos, 168 . 170, 3 to.

Archivio Storico Italiano, No. 329.

Archivio Storico Lombardo, No. 330.

Armitage, E. Early Norman Castles, No. 602. 
Armitage-Smith, S. John of Gaunt, No. 1729 .

Armorial Bearings, No. 672 .

Armour, p. 63.

- Catalogue of, in the Wallace Collections, No. 344 .

Armstrong, E. States of Italy, No. 2344.

Armstrong, IV. Lacroix's Arts in the Middle Ages, No. 6r5.

Army, pp. 189-91.

- History of. Sec Military History.

Armytage, G. Kirklees Priory, No. 2649.

Arnaud d'Agnel, G. Comptes du Roi René, No. 1392.

Arnold, T. Wyclif's English Works, No. 1242.

Arronius, J. Diplomatische Studien, No. 484 .

Arrows and Arrow-makers, No. 618.

Art, No. 1502 .

Artevelde, James van, No. 1999.

Artevelde, Philip van, No. 1999.

Artois, No. 1502.

Arts and Crafts, pp. 63-5.

Arup, E. Studien, No. 1998.

Ashburton, No. 2623.

- Churchwarden's Accounts, No. 1192.

Ashdown, C. H. British and Foreign Arms, No. 619.

Ashdown, Mrs. C. H. British Costume, No. 624.

Ashford, W. H. R. Waterways, No. 2928.

Ashley, IV. J. Anglo-Saxon Township, No. 2121.

- Early Teutonic Society, No. 2122.

- Economic History, Nos. 827, 2276, 2990.

_- English Manor, No. 2135.

_- English Wool Trade, No. 1999a.

James and Philip van Artevelde, No. 1999.

- Surveys, No. 2277.

- Studies and Reviews, p. 13.

— Villein Tenure, No. 2199.

- Woollen Industry, No. 2517.

Ashmolean Museum. See Oxford.

Assessments, pp. 95-99.

Assize Rolls, Northumberland, No. 1088.
Associated Architectural Societies, Index to Reports and Papers, No. 59.

Astle, T. Antiquarian Repertory. No. $278 \mathrm{r}$.

- Great Tey, Essex, No. 2200.

Atkinson, J. C. Coucher Book of Furness Abbey, No. 1121 .

Atkinson, R. Ancient Laws of Ireland, No. 1315.

Atkinson, T. D. Glossary, No. 607.

Atlases, p. 70.

Atthill, W. Middleham Documents, No. 2657.

Atton, H. King's Customs, No. 1943.

Aucoc, L. Conseil d' Etat, No. 1844 .

Aussy, Denis d'. Registres, No. 1443.

Austria, Nos. 1542, 1548, 1563 , 1566, 1571 .

Austria-Hungary, Inventories of Archives, Pp. 23-5.

Auxiliary Studies, Bibliographies of, Nos. 38-76.

Avebury, Lord. See Lubbock, J. Avenel, G. d'. Découvertes, No. 2748.

Histoire économique, No. 2278.

Avery Architectural Library Catalogue, No. 67.

Avignon, No. 1553.

Ayliffe, J. Parergon, No. 485.

Ayloffe, Sir J. Ancient Charters, Nos. $148,918,1244,1293,1326$.

Azeredo, P. A. d'. Archivo da Torre do Tombo, No. 219.

Baader, J. Nürnberger Polizei Ordnungen, No. 1562 .

Babelon, E. Theorie Féodale de la Monnaie, No. 1801 .

Bachtold, H. Norddeutsche Handel, No. 2000.

Baden, No. 1515 .

Badeslade, T. King's Lynn, No. 2925.

Badges, Nos. 655,679 .

Badrelet, J. L. T. Dictionnaire, No. 685 .

Bahr, K. Handel und Verkehr, No. 2074.

Baiäo, A. Archivo da Torre do Tombo, No. 219. 
Baigent, F. J. Basingstoke, No. 2408.

Crondal Records, No. 1153.

Baildon, W. P. Calverley Char. ters, No. 1105.

- I.ittleport Court Baron, No. 1213.

- Select Chancery Cases, No. 1091.

Select Civi! Pleas, No. 1092. Wagkefield Court Rolls, No. 1221.

Baillie-Grohman, W. A. and F. Master of Game, No. 1763.

Bain, E. Merchant Gilds, No. 2454.

Bain, J. Calendar of Documents relating to Scotland, No. 1249.

Baines, F. Lancashire, No. 2369.

Balaguer, V. Estado de la cultura Espanola, No. 2279.

Baldwin, J. F. King's Council, Nos. $1845-48,1850-51$.

- Privy Council, No. 1849.

Scutage, No. 1944.

Ballard, A. Castle Guard, No. 1820.

Cinque Ports, No. 2376.

- Domesday Boroughs, No. 2375.

- Domesday Inquest, No. 2280. Seven Somerton Court Rolls, No. 1217.

-.- Woodstock Manor, No. 2281.

Ballester y Castell, R. Las Fuentas, No. 1646.

Ballinger, J. Cardiff Free Library Catalogue, No. 5.

Balmerino, No. 2624.

Baluze, E. Capitularia Regum Francorum, No. 1417.

_ Simon de Beaulieu, No. 1437.

Balzani, U. Cronache italiane, No. $: 630$.

The Popes, No. 791.

_ Un Ambasciata inglese, No. 1629.

Bankers of Florence, Nos. 2053. 2064.

Banque de St. Georges, No. 2047.

Bannatyne Club, Publications, Nos. $1253-61,1281$.

Banners, No. 655, 679 .

Bar, Duché de, La Chambre des Comples du, No. 1413 .

Bär, M. Rechnungen, No. 1554.

_ Urkunden, No. 1530.
Barbary Corsairs, No. 2057.

Barber Surgeons, No. 2486.

Barbier, J. Analectes, No. 1483 .

Barcelona, No. 1647.

Barddas, No. $13+9$.

Bardsley, C. WV. English Sur. names, No. 399.

Baring, k. Domesday Book, No. 2282.

- Domesday Tables, Nos. 1945. 2284 .

Hidation, No. 2283 .

Making of the New Forest, No. 2897 .

Baring-Gould, S. Family Names, No. 2749.

Barnard, F. P. Companion to English History, No. 576.

Barnard, M. R. Keyser's Old Northmen, No. 2803.

Barnes, W. M. Dorset Pipe Rolls, No. 992.

Barnstaple Records, No. 228.

Baronage, No. 657. See Peerage.

Barros, H. da Gama. Historia, No. 1651 .

Barthold, F. W. Geschichte der deutschen Hanse, No. 2075.

Bartholomaeus Anglicus. De proprietatibus rerum, No. 1236.

Bartholomew Fair, No. 2527.

Bartholomew, J. G. Survey Gazetteer, No. 723.

Bas, F. de. Repertorium, p. 23.

Basel, Urkundenbuch, Nos. 15178.

Basingstoke, No. 2408.

Baslow Court Rolls, No. 1199.

Bateson, M. Borough Customs, No. 2345.

- Cambridge Charters, No. 2417.

Cambridge Gild Records, No. 2455 .

Law's of Breteuil, No. 1876 . Leicester Borough Records, Nos. $260,1128,1212$.

Medisval England, No. 2682. Peterborough Court Leet, No. 1216.

Scottish King's Household, Nos. 1276,1764 .

Bath, No. 2625.

Bath and Wells Episcopal Regisier, p. 117.

Bath Lay Subsidies, No. 1020.

- Poll Tax, No. 999. 
Battle Abbey Custumals, No. I 149.

Baudrillart, H. Histoire du Luxe, No. 2750.

Baumann, J. J. Die Staatslehre des Thomas von Aquino, No. 2991.

Baumgarten, P. M. Aus Kanzlei und Kammer, No. 2556.

- Untersuchungen, No. 1614 .

Bavaria, No $155^{\circ}$.

Bayeux. Cartulary, No. 1354.

Bayley, J. Tower of London, No. 1807.

Bayonne, Nos. 1457, $24 \mathrm{II}$.

Bazeley, M. L. Forest of Dean, No. 2898 .

Beames, J. Glanville's Treatise, No. 1053 .

Béarn, Livres des Syndics de, No. 1438.

Beauchief Abbev, No. 2626 .

Beaucorps, A. de. L'Armée Anglaise, No. I8I I.

Beaumont, La Charte de, No. 2685.

Beaumont, W. Warrington, No. I1 86.

Beaurepaire, R. de. Les états de Normandie, No. 1730.

Beautemps-Beaupré, J. C. Coutumes, No. 1446.

Beauvaisis, Nos. 1447, 1460.

Beazley, C. R. Dawn of Modern Geography, No. 693.

Beck, S.W. Draper's Dictionary, No. 4 I4.

Gloves. Nos. 2495, 2751 .

Bedford, Ancient Charters and Muniments, No. 229.

Domesday Tables, No. 2284 .

Bedford Level, No. 2933.

Beer, No. $275^{2}$.

Beer, A. Allgemeine Geschichte des IVelthandels, No. 2001.

Beer, R. Handschriftenschätze Spaniens, No. 331 .

- Mittelalterliche Bibliotheken Spaniens, No. 332.

Beeston Priory, No. 2628.

Beissel, S. Geldwerth, No. 2002.

Bekynton, Thomas, Official Correspondence of, No. 916 .

Belgian Colonies in England, No. 2005.

Belgium, Nos. 779, 1480, 1481, $1483,1485,2008,2481,2825$.
Belgium, Catalogues of Manuscripts, Nos. $319,313$.

Inventories of Archives, pp.

22-23.

- Inventories of Local Records, p. 38, 39 .

- Sources, pp. 146-8, 164.

Bellesheim, A. Catholic Church in Scotland, No. 822 .

Beloe, E. M. Great Fen Road, No. 2962.

King's Lynn, No. 2648.

Padder's WVay, No. 2963.

Below, G. von. Das ältere deutsche städtewesen, No. 2346.

- Die Verwaltung, No. 2003.

Bemont, C. Chartes des Libertés Anglaises, No. 1048 .

_- Róles Gascons, No. 486.

Benedictines, Nos. 2610, 2625 .

Benevolences, p. 90.

Benham, W. G. Colchester, Nos. III2, 1113.

Bennett, R. Cornmilling, Nos. $2285,2942$.

Bensa, E. Il Contratto di Assicurazione, No. 2992.

Bensington, No. 2168.

Bent, J. T. Genoa, No. 794.

Bequet, A. Les grands domaines, No. 2 I23.

Berdoues, Cartulaire de, No. I37I.

Berg, C. H. E. von. Geschichte der deutschen Wälder, No. 2899.

Berg v'an Middleburgh, F. L. De Nederlanden, No. 2378 .

Bergen, No. 2409.

Bergens Kalvskind, No. 1670.

Bergman, C. G. Studier i Svensk Servitutsrätt, No. 2683 .

Berkeley Castle, No. 2863.

- Catalogue of Charters at, No. 230.

Berkeley Manuscripts, No. 231.

Berkeleys, Lives of the, No. 2846 .

Berkshire Domesday Tables, No. 2284.

Berlin, Nos, 1573, 2024, 2025 .

Bern, No. 1556.

Bernes, Dame Juliana. Treatyse of Fysshynge, No. 2937.

Bernewelle,Liber Memorandorum, No. I101.

Bernheim, E. Lehrbuch, No. 360.

Urkunden, No. I544. 
Bernwode Forest, No. 2913.

Berry, G. G. Introduction to Study of History, No, 360 .

Berry, H. F. Dublin Gild of Merchants, No. 2505.

- Dublin Wills and Inven. tories, No. 1206.

- Statute Rolls, No, 1322.

- Statutes of Ireland, No. 1321.

Berthelet. Dives et Pauper, No. 1229.

Bertrand, A. Table de Revue Archeologique, No. 66.

Berwick-upon-Tweed, No. 2430.

Besançon, Testaments de l'Ofticialite de, No. 1380.

Besançon, A. Cartulaire de Villefranche, No. 1359.

Beugnot, A. Les Olim, No. 1428 . Philippe de Beaumanoir, No. 1460 .

Bevan, E. J. Papermaking, No. $44^{2}$.

Beverley, Nos. 2412, 2629.

Beyr. H. Urkundenbuch, No. 1535 .

Bible, No. 2548.

Bibliographe Moderne, No. 90.

Bibliografia Periodica Romana, No. 106.

Bibliographies, pp. $1-16$.

Bibliotheque de l'Ecole des Chartes. See France, Ecole des Chartes.

Bibliotheque Nationale. See France.

Bickerdyke, J. Ale and Beer. No. 2752 .

Bickley, F. B. Index to Rolls and Charters, No. 271.

Bigelow, M. M. Placita AngloNormannica, No. 1056.

Procedure, No. 3877.

Bigland, R. Gloucestershire Subsidy Rolls, No. 1025.

Biographical Reference, Diction. ary of. No. 850 .

Biography. pp. 65-68.

Biography, Bibliographies of, p. 8.

Birch, W. de G. Cartularium, No. 1304.

- Catalogue of Lincoln Charters, No. 262.

- Early Drawings, Nos. 39. 457.
Birch, W. de G. Index of Styles of Sovereigns, No. $4^{87}$.

- Index to Journal of British Archaeological Associatlon, No. 60.

_ Sea!s, Now 336, 5s28.

Bird, S. R. Scargill. Hattle Abbey

Custumal, No. 1149.

Crown l.ands, No. 2140.

Guide, No. 160.

- Scutage Rolls, Nos. 874. $1018,1946$.

[Birkett, P. Rights of Common. No. 2918.

Bishop, E. Bibliographie gendrale, No. 136 .

Bishop's Stortford, Church. wardens' Accounts, No. 1 :93.

Bishops, Nos. 668, 678.

Blaauw, W. H. Subsidy, No. 973.

Black Book of Limerick, No. 1301.

Black Death, Nus. 2981, 2983.

Black Friars, Nos. 2639, 2635. 264.5, 2647, 2652, 2662, 2673. $2675-80$.

Black, W. H. Leathersellers ${ }^{\circ}$ Company, No. 2503.

Blackie, C. Geographical Etymology, No. 724 .

Blacksmiths' Company, No. 2502 n.

Blair, D. O. Hunter. Bellesheim's Catholic Church in Scotland, No. 822.

Blakesley, G. H. Manorial Jurisdiction, No. 2336.

Blakeway, J. B. Shrewsbury, No. 2445.

Blanche de Castille, No. 1389.

Blanchet, J. A. B. Numismatique, No. 54 \%.

Bled, O. Regestes, No. 1435.

Bliss, W. H. Records of Sweden, No. 225.

Blois, Nos. 1369, $1401,2364$.

Blok, P. J. Geschicdenis, No. 2347.

Oorkondenbock, No. 1489.

_- Rekeningen. No. 1499.

- Reports on Foreign Archives, p. 23.

Bloom, J. H. English Seals, Nos. 53. 529.

Blount, T. Tenures of Land, Nos. 415, 2222, 2753 . 
Bode, G. Urkundenbuch, No. 1522.

Bodeman, E. Die älteren Zunfturkunden, No. 1577.

Bodleian Library. See Oxford.

Böhm, C. E. von. Handschriften, No. 194.

Böhmen, No. 2300.

Böhmer, H. Kirche und Staat, No. 2531.

Böhmer, J. F. Regesta Imperii, No. 1514.

Boileau, E. Le Livre des Métiers, No. I463.

Boinhardt, J. B. Codex, No. 1626.

Boissonnade, P. Essai sur l'organisation du travail en Poitou, No. 2455 A.

- Histoire économique de la France, No. II 9 .

Boldon Buke. See Durham.

Boletin das Bibliothecas, No. 221.

Bolt, Aslak. Jordebog, No. 1666.

Bond, E. A. Facsimiles, Nos. $466,1103$.

- Last Days of Isabella, Queen of Edward II., No. 1765 .

Loans by Italian Merchants, Nos. 986, 2004.

Bond, F. Gothic Architecture, No. $5^{84}$.

Bond, J. J. Handy book, No. $5^{15}$.

Bondmen, Nos. 2233, 2251. See Villeins.

Bonis, frères, No. 1409.

Bonnardot, F. Le Livre des métiers, No. 1463.

Bonnemere, E. La Jacquerie, No. 2684 .

Bonnin E. Regestrum, No. 1436.

Bonvalot, E. Le Tiers état, No. 2685 .

Book of Rights, No. 1316.

Boos, H. Urkundenbuch, Nos. $1517,1546$.

Boose, F. Law Society Library Catalogue. No. 10.

Booth, J. Durham Halmote Rolls, No. 1205.

Borchgrave, E. de. Colonies belges, No. 2005 .

Bordeaux, Nos. 1437, 1444, 2414.

Border History, No. 768 .

Borderie, A. de la. Culture de la vigne, No. 2286.
Bordier, H. Les Archives de la France, p. 19.

Borel, F. Les Foires de Genève, No. 2520.

Boretius, A. Capitularia, No. 1418.

Borle, Extenta Manerii de, No. 1154 .

Bormans, St. Le bon métier des tanneurs, No. 2456.

Borough English, Nos. 2208, 2209, 2245.

Bosworth, J. Anglo-Saxon Dictionary, No. 400.

Boucher de Molandon, R. L'Armée Anglaise, No. 1811.

Boudet, M. Registres consulaires, No. 1441.

Bougenot, E. S. Comptes des dépenses de la maison de la reine Blanche de Castille, No. 1389.

Bouhier, La compilation de, No. 1445.

Bouillon, Famille de, No. 2055 .

Boulting, W. Woman in Italy, No. 2875 .

Bourdot de Richebourg, C. Le Coutumier général, No. 1450.

Bourgain, L. La chaire française, No. 2530.

Bourges, Simon de Beaulieu archeveque de, No. 1437.

Bourmont, A. de. Paléographic, No. 40.

Bourne, H. R. F. English Merchants, No. 2006.

Bourquelot, L. F. Comptes du XIIIe. siecle, No. 1387 .

- Etudes sur les foires de Champagne, No. 2520A.

Bourrienne, V. Antiquus Cartularius, No. 1354 .

Boutaric, E. Actes du Parlement de Paris, No. 1426.

_La France, No. 1731.

__ Institutions Militaires, No. I8 12.

Boutell, C. English Heraldry, No. 650. 640.

Boutmy, F. La formation du Parlement, No. I $85^{2}$.

Bowen, I. Statutes of Wales, No. 1340. 
Bowles, W. L. Lacock Abbey, No. 2651 .

Boyd, W. K. Leicestershire Survev. No. 935.

- Poll Tax, No. 1002.

Boyesen, H. H. Norway, No. 811.

Boyle, J. R. Hedon, No, 2427.

- Kingston-on-Hull, No. 1125. 1.ost Towns of the Humber, No. 2377.

Boys, W. Sandwich, No. 2444.

Brabant, Nu. 780 .

Bracton's De l.egibus, No. 1046.

Bracton's Note-book, No. 1066.

Bradshaw, F. Serldom, No. 2201.

Braine, A. Kingswood Forest, No. 2900.

Brand. J. Expenses of Edward 1. in Wales, Nos. 1015, 1336. Trs.

- Newcastle-upon-Tyne, Nos. $2442,2946$.

- Popular Antiquities, No. 2754.

Rotulus Familia, No. 1016.

Brandenburg. No. 1988.

Brantingham. Thomas of, Issue Roll of. No. 984 .

Brants, V. L'éronomie politique, No. 2993.

Brash, R. R. Ecclesiastical History of Ireland, No. $5^{85}$.

Brasses, Costume on, No. 628 .

Brasswork, p. 64.

Bratko, E. Wegweiser, p. 12.

Bray, WV. Purveyor of the King's Household. No. 1766.

Surrey, No. 714.

Brequigny, L. G. O. F. de. Recherches, No. 2379.

Bresslau, H. Handbuch, No. 488.

Breteuil, Laws of, No. $18 ; 6$.

Bretholz, B. Lateinische Paläographie, No. 432.

Brewer, J. S. Carew Manuscripts, No. 1305.

Bridges, pp. $267-8$.

Bridrey, E. La Theorie de la Monnaie. No. 2994.

Bright, J. S. Endowments, No. 25.85.

Briquet, C. M. Les Filigranes, No. 444 .

Brissaud, D. Les Anglais en Guienne, Nos. 1732, 2007.
Brintol, Nos, 1044, 2413, 2513, 2513. 2630.

Charters of. Nos. 232, 1103.

Rebellion, No. insto.

British Archxoological Aswoxiation. Journal, General Index, No. Go.

British Museum. See London.

Brittany, Nos. 1448, 2386 .

Britton, Laws of England, No. 1047.

Broeckaert, J. Geschiedenis, No. 2402.

Brom, G. Archivalia, No. zso.

- Gulde aux Archives du

Vatican, p. 25.

Bronze Age, No. $34 \%$.

Brooke, T. Catalogue of Manu. scripts at Armitage Bridge House, No. 233.

Broussillon, B. de. Cartulaire, No. 1370.

Brown, G. Baldwin. Ancient Monuments, No. 577.

- Arts and Crafts. No. 613.

Arts in Farly England, No. 612 .

Brown, H. R. F. Venice, No. 795.

Molmenti's Venice, No. 802. Trs.

Brown, J. S. Ciraldi Cambrensis Opera, No. 1339.

Brown, P. Hume. Early Travel. lers, No. 2964.

- History of Scotland, No. 762. Scotland from contemporary Documents, No. 1292.

Brown, R. Accounting, No. 2485.

Brown, W. Yorkshire Deeds, No. 1143.

Yorkshirc Lay Subsidies, No. 1043 .

Brownlow, IV. R. Slavery and Serfdom, Nos. 2202, 2686.

Brown!ow, Rev, Mgr. Visitation of Marychurch, No. 2654.

Brucker, J. Zunft und Polizei Verordnungen. No. 1588 .

Bruder, A. Zur ökonomischen Charakteristik des römischen Rechtes, No. 2995.

Bruges, Nos. 1587, 2081, 2092.

Brugmans, H. Atlas, No. 480.

Reports on Foreign Archives,

p. 23. 
Brun, F. La Vie Privée des Paysans, No. 2687.

Brun-Lavaine, E. Franchises, No. 1453 .

Brunne, Robert of. Handling Synne, No. 1235.

Brunner, H. Das Anglo-Normannische Erbfolgesystem, Nos. $18 ; 8,2203$.

- Entstehung der Schwurgerichte, No. 1879 .

- Geschichte der englischen Rechtsquellen, Nos. 816, 1880 .

— Zur Rechtsgeschichte, No. 2126.

Brussel, N. L'usage général, No. 2124.

Brussels, No. 2473.

- Commission royale d'histoire, No. 320.

Brutails, J. A. Populations rurales, No. 2688.

Bruyssel, E. van. Commerce, No. 2008.

- Table Générale, No. 109.

Bryan, E. A. Mark, No. 2125.

Bryce, J. Holy Roman Empire, No. 782 .

Bryce, IV. M. Scottish Grey Friars, No. 2618.

Brynmor-Jones, Sir D. Welsh People, No. 774 .

Bücher, $\mathbf{k}$. Entstehung der Volkswirtschaft. No. 736 .

- Frauenfrage, No. 2876 .

Buck, W. Der deutsche Handel, No. 2521.

Buckinghamshire. Tables, No. 2284.

History of, No. 713 .

Buckler, W. Ilchester Almshouses. Deeds, No. 1124.

Buckstaff, F. G. Married Women's Property, Nos. 2204, 2877 .

Buechi, A. Freiburger historische Studien, No. 2616.

Bugge, A. Gotlaendingernes Handel, No. 2011.

- Handelen, No. 2009.

- Studier, No. 2010.

Bulasque, T. Bayonne, No. 2411.

Bullen, W. Carew Manuscripts, No. 1305.

Bulletin des Bibliothèques, No. 178.
Bulletin des Comités des travaux historiques, No. 179 .

Bulmerincq, A. von. Ursprung der Stadtverfassung Rigas, No. 2380.

Bunge, F. G. von. Quellen des Revaler Stadtrechts, No. I564.

— Stadt Riga, No. 2381.

- Urkundenbuch, No. 1533.

Burckhardt, J. Die Kultur, No. 1733.

Burghs of Scotland, Ancient Laws, No. 1286.

Burgundy, Nos. 1362, 1408, 1466, 2051, 2224, 2257.

Burgundy, Dikes of, No. 2033.

Burke, J. Royal Families, No. $65 \mathrm{x}$.

Burke, J. and J. B. General Armory, No. 683 .

Burke, U. R. Spain, No. 807 .

Burkhardt, C. A. H. Hand-undAdress-Buch, No. 195.

Burkitt, E. H. Worshipful Company of Curriers, No. 2491.

Burman, C. Utrechtsche Jaarboeken, No. 1504.

Burmester, A. C. Roman Highways, No. 2966.

Burnett, G. Heraldry, No. 682.

- Rotuli Scaccarii, No. 1279.

Burns, E. Coinage of Scotland, No. 542 .

Burrows, M. Cinque Ports, No. 2382.

- Family of Brocas, No. 1767 .

Burton Abbey Surveys, No. 2326.

Burton Cartulary, No. 2282.

Burton, J. H. Register of Privy Council of Scotland, No. 454 .

- The Scot Abroad, No. 2689.

Bury Fair, No. 2524.

Bury St. Edmund, Abbey of, No. 2631 .

Bury St. Edmunds, Will, p. 117.

Bury, Richard de. Philobiblon, No. 1234.

Bury, J. B. Freeman's Historical Geography, No. 696.

- Later Roman Empire, No. 741 .

Butcher, J. Ashburton, Nos. 1192, 2623.

Butchers, Worshipful Company of, No. 2489.

Butler, W. F. T. Lombard Communes, No. $23^{8} 3$. 
Buxhall, No. 2130.

Bysland, Devon, Silver Mines of, No. 2959.

Cade, Jack, No. 1734.

Cadier, L. Livre des Syndics, No. 1438.

Caesar, Sir J. Court of Requests, No. 1853 .

Caggese, R. Classi e communi rurali, No. 2690.

Cahors, Marchands de, No. 1997.

Calais, Nos. $864,2403,2415$.

Caley, J. Rotuli Scotiae, No. 1247.

Calthrop, D. C. English Cos. tume, No. 625.

Calvados, Archives, p. 20.

- Charters, No. 305.

Calverley Charters, No. 1105.

Calvert, J. Gold Rocks, No. 2947.

Calvi, E. Bibliografia di Roma, No. $10 \%$.

Cam River, No. 2929.

Cambrai, Nos. $2387,2388$.

Cambridge, Nos. 2416, $2417,2455$.

- Antiquarian Society, List of

Publications, No. 68.

Castle, No. 2929.

Colleges, Catalogues of

Manuscripts, Nos. 236-46.

_- Watercourse called, No. 2929.

Essays on the Teaching of

History, No. 36 .

- History of English Literature, p. 46.

_ Mediaval History, p. 13.

- Priory of St. Radegund,

No. 2632 .

University, No. 2829.

19. Library Bulletin, No.

- Library Catalogue of Manuscripts, No. 235.

Cambridge University Registry, List of Documents in the, No. 234.

Cambridgeshire, No. 2159.

- Inquisitio comitatus Cantabrigtensis, Nos. 927, 2333.

- Measurements of Domesday of, No. 2334.

- Rivers, No. 2936. 1022 .

Camden Society, Catalogue, No. 128.
Camden, W, Remains, No. s\$8.

Campbell, J. Balmerino, No. 2624.

Chief Justices, No. 65a.

Lord Chanceliors, No. 6s].

Caneparius, P. M. De atramentis, No. 446.

Cannon, H. L. Reading Refer. ences, No. 82.

Canon l.aw, No. 1906.

Canonsleigh, l'riory of, No. 2633.

Canterbury, Friars-l'reachers of, No. 2635.

- Monastery of St. Augustine, No. 2634.

- Province of, No. 1986.

Canynge's Family, No. 2739.

Capasso, B. Archivo di Stato, No. 218.

- Le Fonti della Storia delle Provincic Napolitana, No. 324 .

Capes, W. W. English Church, No. 823 .

- Hereford Cathedral Char. ters, No. 2588.

Capitularies, Nos. 1417-19, 1557.

Capelli, A. Cronologia, No. 516.

- Dizionario, No. 462.

Carcassone, No. 8363 .

Carden, R. W. Genoa, No. 796.

Cardenas, F. Propriedad Territorial, No. 2127.

Cardiganshire Minister's Accounts, No. $: 335$.

Cardiff Free Library, Catalogue of Welsh Department, No. 5.

Cardinals, English, No. 680.

Careu Manuscripts, Calendar of, No. 1305.

Carini, I. Archivi di Spagna, No. 333.

Carlier. La Commerce en France, No. 2012.

Carlisle, Episcopal Register, p. 117.

Carlisle, N. Endowed Grammar Schools, No. 2755.

Carlyle, R. W. and A. J. Mediaral Political Theory, No. 2996.

Carlyle, T. Past and Present, No. 2601.

Carnarvon, Record of, No. $1338 \mathrm{~s}$.

Carnegie Institute of Washington, List of Doctoral Dissertations, No. 33 .

Caro, G. Beitrăge, No. 2013. 
Carolingians, Nos. 1905, 2038.

Carpenters, Worshipful Company of, No. 2488.

Carron Abbey, No. 2627.

Cartae Antiquae, No. 860.

Carte, T. Gascon Rolls, No. 866.

Carthusians, No. 26I I.

Cartularies, England, Nos. 863 , 924, I I I9, I1 29, I135, I137, I151.

- France, Nos. 310, 1353-76.

- Ireland, No. I306.

Cartularium Saxonicum, No. 1104.

Carucage, No. 1984.

Castille, Nos. 1636, 1638 .

Castlecombe, No. 2 I74.

Castles, Nos. 602, 604, 605 .

Catalogues of Museums, pp. 4043.

Cataluña, Manor, No. 2145.

Catholicon Anglicum, No. 403.

Caulfield, R. Rotulus Pipae Clonensis, No. 1310.

Caxton's Book of Curtesye, No. 2777 .

Cazauran, Cartulaire de Berdoues, No. 1371 .

Cecil, E. See Amherst, A.

Celtic Antiquities in Dublin Museum, Guide to, No. 356 .

Celitic Church in Scotland, No. 2545.

Celtic Scotland, No. 2023.

Celts, Nos. 1688, 1689, 1702, $1719,1720,1725,2784$.

Cely Papers, No. 899 .

Chabot, $A$. J. F. de. La Chasse, No. 2921.

Chadwick, H. M. Anglo-Saxon Institutions, Nos. I691, 2128, 2756 .

_- English Nation, No. 1690.

Chadwyck-Healey. See Healey.

Chaffers, W. Gilda Aurifabrorum, No. 2496.

Chalandon, F. Dominion Normande en Italie, No. 797 .

Chalmers, G. Caledonia, No. 694 .

Chalmers, P. Liber S. Thome de Aberbrothoc, No. 1253.

Chambers, E. K. Mediæval Stage, No. 2757.

Chambers, W. Peebles Charters, No. 127 I.

Champagne, Foires de, No. 2520 A.

Champeaux, Compilation de Bouhier, No. 1445.
Champollion-Figeac, J, J. Lettres de rois, No. 905 .

Chancellor's Roll. No. Ioro.

Chancery, p. 188.

- Ancient Rolls, No. 892 .

Cases, No. rogr.

Court of, Nos. 1897, 1932.

Inn of, No. 2096.

Proceedings, Nos. 1077 , 2819.

Rolls, pp. 84, 86 .

Chandler, H. W. Great Cressingham Court Rolls, No. 1206.

Channel Islands, p. 73 .

Chanter, J. R. Barnstaple Records, No. 228.

Chapman, A. B. W. Commercial Relations, No. 2066.

- and M. W. Status of Women, No. 2878 .

Chapman, Archdeacon. Manor and Advowson of Mepal, No. 2587.

Chapman, F. R. Ely Sacrist Rolls, No. 2643.

Charles VI., No. 1393.

Charles the Great, No. 2296.

Charities, Nos. 2867, 3021 .

Charnock, R. S. Essex Manoria! Customs. No. 2205.

- Local Etymology, No. 725.

Charterhouse, No. 2638.

Charter Rolls, Nos. $855,856,859$, 888.

Charters, pp. II3-6, Nos. 863, I $105,1297$.

- Ancient, Nos. 148, 852, 891 , 918.

Anglo-Norman, pp. 83-4, No. 1377 .

- Anglo-Saxon, p. 83.

- Royal, pp. 83-5, Nos. 861, $862,890$.

- Scotland, No. 1245 .

Wales, Nos. 1327, 1328, 1329, 1332, 1333.

Chartraire, E. Cartulaire, No. 1373.

Chartre, Cartulaire de Saint Jeanen-Vallée de, No. 1357.

Chartularies. See Cartularies.

Chatelain, E. Chartularium, No. 1434.

Chaucer, Geoffrey, Nos. 1771, 2760. 
Chaucer's England, No. 2838 .

Chertsey Abbey, No. 2636.

Cheruel, P. A. Dictionnaire Historique, No. 842.

Cheshire, No. 2367.

Chester, Nos. 718, 2418.

- Fines, No. 1346 .

Plea Rolls, No. 1330.

Chester Chamberlain's Accounts, No. 974 .

Chetham Society, Index, No. 129.

Chevalier, U. Repertoire, No. 78.

Topo-Bibliogsaphic, No. 74.

Chevin, Abbe. Dictionnaire, No. 377.

Cheyney, E. P. English Serfdom, Nos. 2206, 2602.

Industrial History, Nos. S28, $275^{8}$.

Chichester Episcopal Register, p. 18.

Chief Justices, No. 652 .

Chipping IVycombe, No. 247.

Chisholm, G. G. Distribution of Towns, No. 695.

- Europe, Nos. 704, 742.

_ Longman's Gazetteer, No. 732.

Chisholm, H. Encyclopedia Britannica, No. 848 .

Chitty, H. Markets and Fairs, No. 1919.

Chivalry, Nos. 2706, 2734, 2759. 2766, 2824 .

Chmel, J. Urkunden, No. 1542.

Chope, R. P. Hartland, No. 2129.

Chretien-Lalanne, M. L. Dictionnaire Historique, No. 843 .

Christchurch Deeds, No. 1304.

Christenson, W. Repertorium, No. 1657.

Christie, J. Parish Clerks, No. 25 i4.

Chronology, pp. 56-7.

Chroust. A. Monumenta Palacographica, No. 478.

Church, pp. $23^{8-49}$.

Church lands, p. 84.

Church, A. H. English Earthenware, No. 645.

Churchwardens' Accounts, pp. 121-2, No. 139.

Cinque Ports, Nos. 1106, 1107. $1116,2376,2382$.
Cirencester, Nos. נigo, 2218, 2295.

Cistercian Hounes, No. 2553.

Cistercians, Nos. 26:2-4, 2663. 2693 .

City Companies, No. 2768.

Civil Pleas, No. 1002.

Civilisation, Histories of, p. 71.

Clairvaux, No, 2614.

Clamageran, L'Impot en France, No. 1947.

Clapham, J. H. Horsing of the Danes, No. 1813 .

Clark, A. Serfdom, No. 2207.

Clark, G. L. Glamorgan, Nos. 1327, 2287.

Clark, G. T. Glamorgan, Nos. $1327,2287$.

Mediaval Military Archltecture, No. 603 .

Rothley Customary, No. 1181.

Clark, J. W. Architectural History, No. 287 t.

_ Care of Books, No. 447.

Liber Memorandorum, No. 181.

Clarke, G. H. Primer of Old French, p. 45.

Classes of Society, pp. 249-53.

Classical Heritage of the Middle Ages, No. 2856.

Clay, J. W. North Country Wills, p. 117.

Clay, R. M. Mediaval Hospltals, Nos. 586, 2978.

Clayton, J. Jack Cade, No. 1734-

Cledat, L. Petit Glossaire, No. $3^{8} 5$.

Clemence, J Roi de Navarre, No. 1391.

Clepham, R. C. Hanseatic Confederation, No. 2076.

Clergeac, A. Cartulaire, No. 1375.

Clerical Life, pp. 241-2.

Clinch, G. English Costume, No. 626.

Clitheroe Charters, No. tros.

Honor Court Rolls, No. 1202.

Clive, R. H. Documents, No. 134 .

Clode, C. M. Merchant Taylors, No. 2512.

Close Rolls, Nos. 875, 889.

Ireland, No. 1299. 
Clouzot, E. Cartulaire, No. 1376. Clowes, Sir W. L. Royal Navy, Nos. $824,1814$.

Cloyne Pipe, No. 1310.

Cluniacense Monasticon, No. I 109.

Clutterbuck, R. Hertford, No. 707.

Clyde Boroughs, No. 2419.

Coal Trade, No. 2960.

Coats of Arms, No. 691.

Coblenz, Nos. I530, 1535,1554 .

Cockayne, O. Leechdoms, No. 1236.

Cockersand Abbey Chartulary, No. 1151 .

Codex Diplomaticus, No. I1 10.

Codrington, T. Roman Roads, No. 2965 .

Coffey, G. Guide to Celtic Antiquities, No. 356 .

Coinage, Nos. 1949, 1954.

Coins, pp. 58-9, Nos. 335, 337 , 345, 355. See Numismatics.

Cockayne, G. E. Complete Peerage, No. 654 .

Colchester, Assessment Rolls, No. 954.

Catalogue of Antiquities, No. 334 .

- Charters, Nos. 248, i I1I.

- Red Paper Book, No. 1112.

- Red Parchment Book, No. III3.

Coldingham Correspondence, Nos. I152, 1277 .

Cole, H. Documents, Nos. 876 , IOII, 1079.

Collin, H. S. Corpus Juris SueoGotorum, No. 1669.

Collingwood, W. G. Scandinavian Britain, No. 1692.

Colston, J. Incorporated Trades, No. 2457.

Collyer, R. Ilkley, No. 1209.

Cologne, Nos. 1531, 1555, 1572 , $1576,2078$.

Colonisation, No. $206 \mathrm{I}$.

Combat, Trial by, No. 1914.

Commercial Relations, pp. I06, 201-10.

Common Pleas, p 106.

Commons, Nos. 1931, 2237, 2255, $2327,2328$.

Communications, Means of, pp. 266-8.

Conder, E. Hole Craft, No. 2504.
Confirmations, pp. 83-5.

Conigliani, C. A. Economia Politica, No. 2997.

Connor, Ecclesiastical Antiquities, No. I3II.

Conseils d'état, Arrêts du, No. 1429.

Constitutional History, p. 76.

— Bibliographies of, p. 12.

Continents, Histories of, pp. $7^{1-2}$.

Contzen, H. Geschichte der Volkswirthschaftlichen Literatur, No. 2998.

Conveyancer, Thirteenth Century, No. 1200.

Conybeare, J. IV. E. Roman Britain, No. 1693 .

Cook, C. H. Ale and Beer, No. 2752.

Cooke, A. M. Cistercians, No. $2613,2693$.

Cookery, Nos. 2830, 2860.

Cooper, C. H. Cambridge, No. 2416.

Cooper, C. P. Account of Public Records, No. 149.

- Proceedings of Commissioners, No. 1007.

Coopers' Company, No. 2490.

Coote, H. C. Romans of Britain, No. 1694 .

Cope, E. E. See Thoyts, E. E.

Copenhagen, No. 1655 .

Copinger, W. A. Buxhall, No. 2130.

Materials, No. 288.

Copyhold, Nos. 1875, 2228, 2250 , 2270.

Corbett, W. J. Hepworth, No. $213 \mathrm{I}$.

Cornage, No. 2225.

Corner, G. R. Borough English, Nos. 2208, 2209.

Corneto, No. 1631 .

Cornish, F. W. Chivalry, No. 2759.

Cornmilling, Nos. $2285,2942$.

Cornwall, Nos. 2950, $295^{8}$.

- Poll Tax, No. 1000.

Coronation Claims, Nos. 1768 , 1792.

Coroners' Rolls, No. 1903.

Cossa, L. Economia Politica, No. 2999.

Costelloe, B. T. C. Fairs and Markets, No. 2522. 
Costume, pp. 63-4, Nos. 65, 2837.

Cotgrave, R. French-English Dictionary, No. $3^{86 .}$

Cotton, Archbishop, Acts of, No. 1309.

Coucher Book of Furness Abbey, No. 1121.

Coulton, G. G. Chaucer, No. 2760.

- Education of Women, No. 2881.

Failure of the Friars, No. 2619.

- Franciscans, No. 2615.

Monastic I,rgend, No. 2542.

Priests and People, No.

2575.

Religious Education, No. 2576 .

- Truth about the Monasteries, No. 2543.

Council, pp. 191-3.

County Court, No. 2231.

County Histories, pp. 69-70.

Court and Houschold, pp. 186-7.

Court I.eet, Nos. 2341, 2342.

Court Rolls, pp. 123-5, No. 273.

Ruthin, No. 1347.

Courts of Love, Nos. $2820,2842$.

Courtney, W. P. Register, No. 1.

Coventry, Nos. 2420, 2493, 2637, 2792.

- Laurence Saunders, Citizen of, 2708.

L- Leet Book, No. 1201.

Pageants, No. 2845 .

Cowper, J. M. Churchwardens' Accounts, pp. 121-2.

Cox, J. C. All Saints, Derby, Nos. 1194, 2586.

Church of the Holy Sepulchre, Northampton, No. 2659.

Derbyshire, No. 1948.

Derbyshire Subsidy Roll, No. 1023 .

- English Church Furniture, No. 634 .

- How to write the History of

a Parish, No. 362.

Lichfield, No. 26r.

Mining Operations, No. 2948.

Royal Forests, No. 2901.

Sanctuaries, Nos. $1881,2607$.

Coxe, H. O. Catalogue of Bodleian Library Charters, No. 276.
Coxe, H. O. Catalogue of Manuscripts in Oxford Colleges, Nos. $275,278$.

Cowel, J. Law Dictionary, No. 416.

Cracow, No. 1552.

Craftswomen, No. 2879 .

Crawford Collection, No. 1114.

Crawley-Boevey, A. W. Flaxley Cartulary, No. 1119.

Crecy, Nos. 864. 1822.

Creighton, C. Epidemics, No. 2979.

Creighton, M., Bibliography of, No. 144.

Papacy, No. 792.

Crests, No. $65^{8}$.

Crime, Nos. 1921, 1067.

Cripps, W. J. Old English Plate, Nos. 646, 2497.

Crisp, F. A. Ipswich IVills, No. 257 .

Crispin, Gilbert, Abbot of Westminster, No. 2677.

Crondal Records, No. 1153.

Cronholm, N. N. Sweden, No. 814.

Cross, C. F. Paper-making, No. $44^{2}$.

Crossbow, Nos, 623, 1835 .

Croston, J. Baines' Lancashire, No. 2369.

Crown, pp. 186-91.

- Ancient Pleas of the, No. 1047.

- Grants from the, No. 867 .

- Jewels, No. 982 .

_Lands, No. 2140.

- Pleas, Nos. 1068, 1094.

- Revenues, No. 1087 .

Crump, C. C. English Currency, No. 1949.

Crusades, Nos. 309, 2055, 2117.

Cullum, J. Hawstead, No. 2132.

Cumberland Bridges, No. 2970.

_ Pipe Rolls, Nos. 989, 990.

Wills, p. It7.

Cunningham, T. Customs, No. 1950.

Cunningham, W. Alien Immigrants, No. 2694.

- Cambridgeshire Rivers, No. 2926.

Christian Opinion on Usury, No. 3000 .

Commercial Policy of Ed. ward III., No. 2014. 
Cunningham, W. English Industry and Commerce, Nos. 829, I154.

- Presidential Addresses, No. 763.

Western Civilisation, No. 743.

Cupar-Angus, Rental Book, No. 1262.

Curia Militaris, No. 1069.

Curiæe Regis Rotuli, No. 1078.

Curie-Seimbres, A. Essai, No. 2384.

Currency, No. 1949.

Current Bibliographies, p. 3 .

Curriers, Worshipful Company of, No. 2491.

Curschmann, F. Hungersnöte, No. 2980.

Curtler, W. H. R. English Agriculture, No. 2288.

Curzon, H. de. La Règle du Temple, No. 2107.

Customs, pp. 253-60, No. 2767.

_ King's, Nos. 1943, 1950.

- Manorial, p. I06.

Custumals, p. 118 .

Custumaries, France, pp. 161-2.

Customary Rents, No. 2238.

Customs House, No. 2096.

Cusumano, V. Economia Politica, No. 3001 .

Cuthbert, Father. The Friars, No. 2617.

Cutts, E. L. Parish Priests, Nos. $2577,2696$.

- Scenes and Characters, No. 2695.

Cuvelier, J. Archives Générales du Royaume, No. 181.

- Le Rôle des Archives, p. 2 I.

Cyprus, Hospitallers at, No.2112.

Daenell, E. Die Blütezeit, No. 2077.

Die Kölner Konfederation, No. 2078.

Dahlmann-Waitz, Quellenkunde, No. 95.

Dahn, F. Zum merowingischen Finanzrecht, No. 1951.

Dale, E. National Life, No. 2761.

Dalrymple, J. Feudal Property, No. 2210.

Dalyell, J. G. Darker Superstitions of Scotland, No. 2697.

Danegeld, Nos. 1979, 1981, 2192.
Danes, Nos. 1715, 1723, 1727, 1813.

Daniell, W. V. British Topography, No. 75 .

Dansk Historisk Forening, No. II6A.

Danzig, No. 2083.

Dareste, C. Classes agricoles, No. 2698.

Darmesteter, A. Grammaire Historique. p. 45 .

Dartford Priory, No. 2639.

Dartmoor, Nos. 2237, 2918, 2919.

Dasent, G. W. Icelandic Sagas, No. 1684 .

- Norsemen in Iceland, No. 2762.

Story of Burnt Njal, No. 2763. Trs.

Dashwood, G. H. Subsidy Roll, No. 1032.

Dates, Dictionary of, No. 846 .

Davenport, F. G. Classified List, No. izo.

Decay of Villeinage, No. 22 II.

Norfolk Manor, No. 2289.

Davidson, J. Scottish Staple, No. 2094.

Davies, J. S. Southampton, No. 2446.

Davies, R. York Municipal Records, No. 1142 .

Davis, C. W., p. 84 .

Davis, H. W. C. England under the Normans and Angevins, No. 1735 .

Davis, J. E. Windsor. No, 1809.

Davis, M. D. Hebrew Deeds, No. 920.

Daw, J. Worshipful Company of Butchers, No. 2489.

Dawkins, W. Boyd. Early Man, No. 559.

Dax, No. $145^{8}$.

Day, C. Commerce, No. 830.

Dean, Forest of, Nos. 2898, 2905. 2916.

_ Iron-making in the, No. 2957.

- Miners in the, No. 2949.

Débats des Hérauts d'Armes, No. 1228.

Decrusy, Recueil général, No. 1421.

Deeds, p. 116 . 
Deeds, Welsh, No. $133^{\circ}$.

Decdes, C. Winchester Munlments, No. 292.

De Gids, No. 191.

Dehaisnes, C. Documents. No. 1502.

De Lacy. Accounts, Nos. 1155. 1856.

Delaunay, M. F. Table Decennale, No. 66.

Delaville le Roulx, J. Cartulaires, No. 1364 .

Registres, No. 1404.

Delisle, I. Actes de Henri II., Nos. $467,493$.

Actes Normands, No. 1384.

Album Paleographique, No.

471.

Bibliographie des Travaux

de, No. 131.

Cabinet, No. 472.

Cartulaire Normand, No. 1353.

- Chartes de Henri II., Nos. 489. 490, 492.

Classe Agricole, Nos. 2699. 2700.

Chronologie, No. 1415.

Ecole Calligraphique, No. 426.

Inventaire Générale, No. 307 .

- Jugements de l'echequier de Normandie, No. 1385.

Operations financières des

Templiers. No. 2108.

- Rex Anglorum, No. 491.

_ Rouleaux des Morts, No. 1432.

Windmills, No. 2943.

Delpech, Tactique militaire, No. 1815.

Delpit, J. Collection généräle, No. 304.

- Livres de Bouillons, No. 1456.

Demay, G. Costume, No. 627. 530 .

Denbighshire, No. 2193.

Denicke, H. Hansestädte, No. 2079.

Denifle, H. Chartularium, No. 1434. - Dessolation des Eglises, No. 88,6 .

Documents, No. 1433.

Universitaten, No. 2764 .
Denmark, Nos. 810, $1727,2079$.

$2091,2476,2484,2737$.

Bibliography, No. 116A.

Catalogues of Manuscripts.

No. 314.

- Inventories of Archives, $p$. 38.

- Sources, pp. 154.5, $178-80$.

Denton. WV. England, Nos. 1736 . 2765.

Deodands, Yorkshire, No. 979.

De Pas, J. Cartulaire, No. 1372.

Depping, C. P. L.e Livre des

Metiers, No. 1463.

Deprex, E. Ambassades Anglaises, No. 901 .

- Etudes, Nos. 494, 900.

- Jean le Bel, No. 917.

Derby, Nos. 721, 2800.

All Saints. Chronicles of, Nos. $1194,2586$.

- Henry, Earl of, No. 1839.

Pipe Rolls, No. 996.

Derbyshire, No. 1948.

- Charters, No. 249.

Subsidy Roll, No. 1023.

Derry, Rental, 1309.

Dersalles, L.. Rançon du rol Jean, No. 1394.

Deschaisnes, Douai, No. 2386.

Desjardins, A. Etats généraux. No. 1854 .

Deutsche Zeitschrift, No. 96.

Devillers, L. Cartulaire, No. 1478.

Inventaire Analytique, No. 182.

Devizes, Catalogue of Library of Museum, No. 353.

Devon, Nos. 2237, 2553, 2918. 2958.

Pipe Rolls, No. 991.

Devon, F. Issues of the Exchequer, No. 983 .

I Issue Roll, No. 984 .

Devonshire Domesday, No. 928.

Dewsbury, No. 2640.

Dezobry, L. C. Dictionnaire, No. 685 .

Dibben, L. B. Secretaries, No. 1769.

Dicey, A. V. Privy Council, No. 1855.

Dickson, T. Accounts of I.ord High Treasurer of Scotland, No. 1278 . 
Dickson, W. Northumberland Pipe Roll, No. 995.

Dickson, W. P. Mommsen's Roman Empire, No. 1713. Trs. Dictionaries, pp. 78-9.

Dietrich, F. Bibliographie, No. 97.

Differee, H. C. De Geschiedenis, No. 2015.

Digby, Sir K. E. Law of Real Property, No. 2212.

Dillon, H. A., Viscount. Ordinances of Chivalry, No. 2766.

Dimock, J. F. Geraldi Cambrensis Opera, No. 1339.

Diplomatarium, No. 1115.

Diplonatic, pp. 54- $\delta$.

- Bibliographies of, pp. 5-6.

Diplomatic Documents, England, pp. 83-95.

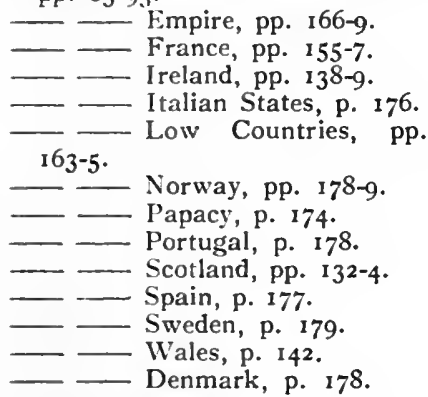

Dioceses, English, No. 2549.

Ditchfield, P. H. City Companies, No. 2768.

Manor Houses, No. 595.

Old English Sports, No. 2767 .

Dives et Pauper, No. 1229.

Dixon, E. Craftswomen, No. 2879.

Dog, British, No. 2922.

Domesday Book, pp. 96-8, Nos. 1968, $2158,2280,2282,2291-4$, $2305,2320$.

- Bibliography of, No. 132.

2334 .

Cambridgeshire, No.

— Facsimiles, No. 929 .

2330.

Gloucestershire, No.

2330.

Norfolk, No. 2314. See

also under Counties.

Domesday Boroughs, No. 2375 .
Domesday, Finance of, No. 1981.

Manor, No. 2172.

__ of Inclosures, No. 2298.

of St. Paul's, Nos. 1157 ,

2301.

- Satellites of, pp. 96-8.

Studies, Nos. 1952, 2290.

Tables, Nos. 1945, 2284.

Doncaster, No. 2641.

Court Rolls, No. 1203.

Doniol, H. Classes agricoles, No. 2701 .

Donisthorpe, W'. Measures, No. 543.

Dordrecht, No. 1492.

Dordtsche Stapelrecht, No. 2439.

Doren, A. Deutsche Handwerker, No. $245^{8}$.

—_ Entwicklung, No. 2460.

- Untersuchungen, No. 2459.

Doren, J. Princes of Wales, No. 656.

Dorset, Nos. 7 I1 $, 2368,2563$.

- Inquisitions, No. $967 n$.

- Pipe Rolls, No. 992.

- Survey, No. 2292.

Dortmunder Statuten, No. $155^{8}$.

- Urkundenbuch, No. 1520.

Douai, Nos. 1955, 2386.

Doubleday, H. A. Victoria County History, No. 2366.

Doublet, F. J. Abbaye de St. Denys, No. 1468.

Douet d'Arcq, L. Comptes de l'argenterie, Nos. 1395-6.

Douglas, R. Langton. States of Italy, No. 2344.

Dove, P. E. Domesday Bibliography, No. 132.

Domesday Studies, Nos. 1952, 1981, 2290.

Dover, Nos, $1116,2421$.

Dowden, J. Celtic Church, No. 2545 .

Lindores Chartulary, No. 1274.

Mediæeval Church, No. 2544.

Dowell, J. Taxation, No. 1953.

Down, Ecclesiastical Antiquities, No. 1311.

Dozy, C. M. Dordrecht, No. 1492.

Drake, F. Eboracum, No. $245^{2}$.

Drake, H. H. Hasted's Kent, No. 709.

Dramard, E. Bibliographie, p. 
Drengage, No. 2225.

Dress, Anglo-Saxon, No. 2796.

Driault, E. Vue gentrale, No. 737.

Drinking Custoons, No. 2789.

Dromore, Ecclesiastical Antiquities, No. '311.

Droysen, J. G. Grundriss, No. 363.

Druitt, H. Costume, No. 628.

Dryburgh, Liber S. Marie de, No. 1254 .

Dryden. A. Twici's Art of Hunting, No. 2924.

Dryhurst, N. F. and A. R. Nys's Economics, No. 3024, Trs.

Dublin, Ancient Records of, No. 1294.

"Crede Mihi," No. 1295.

Gilds, No. 2505.

National Museum, Celtic Antiquities, No. 356.

- Public Record Oflice, Deputy

Keeper's Reports, No. 165. See Public Record Office, Ireland.

St. Mary's Abbey, cartularies, No. i3o6.

Scandinavian Kingdom of, No. 770.

- Science and Art Museum, Catalogue of Irish Coins, No. 544.

Wills, No. 1296.

Dubrulle, H. Cambrai, No. 2387.

Du Cange. C. du Fresne. Glossarium, No. 378 .

Du Chaillu, P. B. Viking Age, No. 1695 .

Duchesne, L. Liber Censuum, No. 1610

- Liber Pontificalis, No. 1622.

Duchy Courts, p. 106.

Duchy of Lancaster, Chancery Rolis, No. 892.

- Patent Rolls, No. 893.

Charters, No. 89 s.

Duckett, G. F. Cluniacense Monasticon, No. 1109 .

- Letter from Stephen, Prior of St. John of Pontefract, No. 2668.

Marches of Wales, No. 1882.

Ducourtieux, P. Registres Consulaires, No. 1439 .

Dueholms Diplomatarium, No. 8554.
Duff, F. G. John Rylands tibrary Catalogue, No. 16.

Duffy, B. Tuscan Republice, No. -2 s.

Dufourmantelle, Marine frangaise, No. 1818 .

- Marine Militaire, No. 1817.

Dugdale, Sir W. Baronage, No. 657.

- Imbanking. No. 2927.

Monasticon, Nos. 250, 1117. 1158.

- Summons to the Great Council, No. 865.

Dümmler, F. Deutschlands Cieschichtsquellen, No. 104.

Dunbar, A. H. Scottish Kings, No. 517.

Duncan, L. L. Wills, p. 187.

Dundas, J. Feudal Law, No. 1883.

Dunfermline, No. 2514.

- Register of, No. 1255.

Dunn Pattison, R. P. Black Prince, No. 1737.

Dunning, W. A. Political Theories, No. 3002.

Dunster, No. 2154.

Dupin, A. M. Apanages, No. 2133.

Dupuy, P. Templiers, No. 2109.

Durham, Nos. 720, 2151, 2201, 2422, 2423.

- Abbey Account Rolls, No. 1159.

Boldon Buke, Nos. 930, 94 t.

- Depositions, No. 1204.

- Domesday Book, No. 2423.

- Episcopal Register, p. 137.

— Pipe Rolls, No. 990.

- Priory, Feodary, No. 1160.

— Halmote Rolls, No.

1205.

- See of, Hatficld's Survey. No. 1164 .

Wills, p. 117.

Durieux, A. Les drapiers Cambresiens, No. 2388.

Duvivier, C. Actes, No. 1479.

Dwellings, Anglo-Saxon, No. 2796.

Dyer, L. Political Economy, No. 2909.

Dyer, T. F. F. British Popular Customs, No. 2760.

_ English Folk-lore, No. 2770.

Earle, J. I.and Charters, Nos. 495. 1126, 2213. 
Earthworks, No. 601 .

East Anglia, No. 2728. 1006.

Ebengreuth, A. Luschin von. Allgemeine Münzkunde, No. 1954.

Eberstadt, R. Ursprung, No. $246 \mathrm{r}$.

Ebert, A. Geschichte der Litteratur, No. 98.

Ebner, A. Die Kloesterlichen Gebetsverbrüderungen, No.2532.

Ecclesiastical Courts, France, No. 1884.

Ecclesiastical History, pp. 76-7. Bibliographies of, p. I2.

1483 .

_. Inquisitions, Nos. 970-3.

- Law, No. 1920.

Eckenstein, L. Woman under Monasticism, Nos. 2533, 2880.

Eckertz, G. Quellen, No. 1572.

Economic History, pp. 77-8.

- Bibliographies, p. 12.

Thought, pp. 269-72.

Eden, F. M. State of the Poor, No. 2771.

Edgar, J. Early Scottish Education, No. $277^{2}$.

Edinburgh, Nos. 2457, 2474.

- Advocates' Library Catalogue, No. 7 .

Charters, No. 1269.

National Museum of Antiquities, Catalogue of Coins, No. 554.

Records of, No. 1287.

- Register House, Reports of Deputy Clerk Register, No. 162 .

Education, Nos. 2576, 2772, 2776 , 2881, 2884, 289 I.

Edward the Confessor, Laws of, No. 1901.

Edward 1., Expenses in Wales, Nos. $1015,1336$.

- Financial Transactions, p. 93.

- Welsh Wars of, No. 1830.

Edward 11., No. 1776.

Edward III., No. 1748 .

—- Commercial Policy of, No. 2014.

Edward IV., No. 1757.

Edward V., Grants from the Crown during the reign of, No. 867.
Edwards, E. Libraries, No. 251.

Edwards, J. Gilbertines, No. 2621.

Eggleston Abbey, No. 2642.

Egli, J. J. Nomina Geographica, No. 726 .

Ehrle, F. Beitrage, No. 3003.

Eitelberger von Edelberg, R. Quellenschriften, No. 62 .

Ellis, H. Domesday, No. $229 x$.

— Exon, Domesday, No. 943.

—_ Liber Winton, No. 945.

- Northamptonshire Geld Roll, No. 946 .

- Original Letters, No. 902.

- Record of Carnarvon, No. 1338 .

Ellis, H. J. Facsimiles, No. 470.

- Index to Charters, No. 271.

Ellis, T. E. (Lord Howard de

Walden). Seals No. 531. See

Walden.

Elton, C. J. Custom and Tenant Right, No. 2215.

- Fairs and Markets, No. 2522.

Origins, No. 1696.

Robinson's Common Law of

Kent, No. 2245.

Tenures of Kent, No. 2214.

Elton, J. Cornmilling, Nos. 2285 , 2942.

Elton, O. Saxo Grammaticus, No. 1677 .

Elvin, C. N. Heraldry, No. 686.

Ely, Episcopal Records, No. 252.

Inquisitio Eliensis, Nos.

927,944 .

Prior and Convent of, No. $25^{8} 7$.

- Sacrist Rolls of, No. 2643.

Emerson, O. E. Middle English

Reader, p. 46.

Empire, pp. 166-73.

Encyclopædias, pp. 78-9.

Endemann, W. Nationalökonomischen Grundsätze, No. 3004 .

- Studien, No. 3005.

Endowments, Ecclesiastical, pp. 242-3.

Engel, A. Répertoire, No. 55.

Traité, No. 545.

England, Bibliography, p. 9 .

Facsimiles, p. 53.

- Histories of, p. 72.

- Inventories of Archives, pp. 17-18. 
England, Kings of, Letters, No. 905.

- Queens of, Letters, No. po5. Social and Economic History, Nos. 827, 828, 829, 837. 839. No. 728 .

English Catalogue of Books, No. so.

English Historical Review, Index, No. 83 .

Ennen, I.. Quellen, No. 1572.

Enns, No. 1519.

Epidemics, Nos. 2979, 2982.

Episcopal Registers, pp. 116-7, $160-1$.

Epistolary Documents, pp. 89-93.

Erler, G. Liber Cancellariae Apostolicae, No. 1616.

Erlestoke, No. 2191.

Erslev, K. Repertorium, No. 1657.

Espinas, G. Doctrines Economiques, No. 3006.

- Dowai, No. 1955.

- Recueil de Documents, No. 1482.

Essex, Nos. 2205, 2207.

- Forest of. No. 2902.

Estrup, H. F. J. Om Traeldom, No. 2702.

Eton College Manuscripts, No. 253.

Europe, Economic History, No. 834.

Histories, Nos. 74t-5t.

Evans, A. W. W. Welsh Mediaeval Law, No. 1348 .

Evans, D. S. Welsh Dictionary, No. 413 .

Evans, Sir. J. Bronze Implements, No. 560.

Coins, No. 546 .

Evans, J. G. Liber Landavensis, No. 1350.

Welsh Manuscripts, p. 30.

Ewald, P. Exempla, No. 482.

Exchequer, Nos. 1936, 1990, 1991. Ancient Calendars of, Nos. 155. 922, 1080. Antiquities of, No. $196 \mathrm{~s}$. Chamber, No. 1966.

"Dot" System of, No. 1695.

- Issues of, No. 983 .

Law of, No. 1925.
Exchequer, Liber Niger Scaccarii, No. 957 .

- Hilstory of, No. 1967.

- of Normandy. Great Rolls

of, No. 987 .

— Receipt Roll of, Nos, 8009. 1963.

Red Book of, Nos. 968, 1964.

- Rolls, Scotland, No. 1979.

- Treasury of Receipt, Calen.

dar of Diplomatic Documents, No. 910.

Exeter, Monasticon, No. 1118.

Exmoor, Royal Forest of, No. 2907.

Exon Domesday, No. 943.

Extensions, p. 52.

Extents, p. 118 .

Enipire, p. 169.

Fyton, R. W. Court and Household, Nos. $1738,1770$.

- Domesday, Nos. 2292-4.

Domesday Studies, Nos. 947-8.

Shropshire, Nos. 708, 2372.

- Staffordshire Pipe Rolls, No. 997.

Faber, R. Fntstehung des Agrar. schutzes, No. 2016.

Fabre, P. Denier de St. Pierre, No. 2557.

- Liber Censuum, No. 1610.

Facsimiles, Collections of, pp. 53.4.

- Indices to, Nos. 51-2.

Listes des recueils de, Nos. $47,49$.

Fagniez, G. Collection des Docu. ments, No. 1464 .

$\longrightarrow$ Fitudes. No. 2389.

Fairbairn, J. Book of Crests, No. 658 .

Fairbank, J. R. House of the Greyfriars, No. $26+1$.

Fairholt, F. W. Costume, No. 629.

Fairs, pp. 84, 238 . No. 1919.

Family (The), No. 2782.

Family Names, No. 2749.

Fant, E. M. Scriptores, No. 1676.

Farrer, W. Cockersand Chartu. lary, No. IIst.

Clitheroe Court Rolls, No. 
Farrer, W. Court Rolls of Thomas, Earl of Lancaster, 1211.

Feith, J. A. Oorkendenboek No. 1489 .

Félix, J. Comptes de Rouen, No. 1403.

Fens, Nos. 2927, 2932, 2933, 2935.

Ferguson, J. Architecture, No. 579.

Wills, p. 117.

Ferguson, J. Architecture, No. 579.

Ferries, No. $297 x$.

Ferris, E. Knights Templars, No: 2 IIO.

Fester, R. Regesten, No. 1515.

Feudal Aids, Nos. 955,965 .

Ffoulkes, C. Armour, No. 620 .

Fifteenths, Nos. 1017, 1045.

Figanière, F. F. Portuguese Manuscripts, p. 27.

Figanière, J. C. de, Bibliographia Historica Portugueza, No. II 5 .

Files, G. T. Anglo-Saxon House, No. 596.

Fine Art, Bibliography of, No. 68.

Fine Rolls, Nos. 877, 881, 1081 .

Fines, Chester and Flint, No. 1346.

Fines, Feet of, Nos. 1070, 1071, I082.

Finke, H. Papsturkunden, No. 1603 .

- Pappstum des Templerordens, No. 2111.

Finland, No. I680.

Finot, J. Comtes de Flandre, No. 1405 .

_ Etude Historique, No. 2017.

Firth, J. F. Coopers' Company, No. 2490 .

Fisher, H. A. L. Mediæval Empire, No. 783 .

Fisher, W. R. Forest of Essex, No. 2902.

Fisheries, pp. 264-5, No. I911.

Fittis, R. S. Sports and Pastimes, No. 2773 .

Fitzherbert, A. Natura Brevium, No. 496.

Flammermont, J. L'Industrie à Lille, No. 2390.

Flanders, p. 74, Nos. 1498, 1502 , $2017,2019,2020,2071,2074$, 2402.

Flaxley Cartulary, No. 1119.
Flemings, No. 2036.

Flemish civilisation, No. 2797.

Flenley, R. Merchants, No. 2018.

Fleta, Nos. 1049, 1793.

Fletcher, W. G. D. Black Friars, No. 2662.

- Shrewsbury Poll Tax, No. IOOI.

- Shropshire Lay Subsidy Roll, Nos. 1033, 1956.

Flete, J. Westminster Abbey, No. 2601 .

Flint Fines, No. 1346 .

Florence, Nos. $215,805,1633$, 2405A, 2460.

_- Bankers of, Nos. 2053, 2064, 2572.

Foedera, Nos. 878,907 .

- Syllabus of Documents in, Nos. $897,908$.

Folcland, No. 2265.

Folk-lore, No. 2770 .

Food, Anglo-Saxon, No. 2796.

Forbes, U. A. Roman Highways, No. 2966.

— Waterways, No. 2928.

Forcalquier, No. 1477.

Fords, No. 2971.

Fordwich, No. 2424.

Foreign Merchants, Nos. 2018, 2021.

Foreshore, No. 1912.

Forest Courts, p. Io6.

- Laws, p. 263, No. 1907.

_ Laws, France, No. 1917.

- Perambulations, p. 263 .

— Pleas, Nos. 1072, 1096.

- Pseudo-Cnuts Constitutiones

de Foresta, No. 1902.

Tenures, No. 2274.

Forestié, E. Frères Bonis, No. 1409.

- Jacme Olivier, No. 1406.

Forestré, G. Vie rurale, No. 2703.

Forests, pp. 262-4.

Fornari, T. Delle teori economiche, No. 3007.

Fortescue, G. K. List of Bibliographical Works in the British Museum, No. 2.

Fortescue, Sir J. De Laudibus, No. 1050.

- Governance of England, No. 1922.

Fortescue, J. W. British Army, No. 1819 . 
Fortieth (subsidy), No. 1970.

Fosbrooke, T. D. British Mon. achism, No. 2546.

Foss, F. Judges, No. 659.

Foster, J. l'eerage, No. 660.

Foster, IV. E. Point of View in History, No. 364.

Founders, Worshipful Company of, No. $249^{2}$.

Fournier, $\mathbf{l}$. Les Orficialites, No. 1884.

Fowke, F, R. Bayeux Tapestry, No. 647.

Fowler, J. C. Benedictines, No. 2625.

Fowler, R. C. Cistercian Scholars, No. 2663.

Fowling. No. 2939.

Fox, F. F. Merchant Taylors, No. 2512.

Weavers, No. 2513.

Fox-Davies, A. C. Boutell's English Heraldry, No. 650.

France, Works relating to, p. 73. Nos. 1731, 1746, 1794. 1795. $1812,1817,1818,1827,1884$, 1885. 1939. 1947. 1969, 1973. 1975. 1993, 2012, 2017, 2028. 2045, 2046, 2054, $2124,2175$. $2378,2349,2360,2363,2384$. $2481,2530,2536,2538,2698$, $2701,2714,2720,2732,2733$. $2778,2785,2786,2807-9,2835$. $2837,2864,289$ 1.

Bibliographies, p. 10, Nos.

29, 119.

Bibliotheque Nationale, Catalogues, Nos, 307, 308.

- Catalogues of Museums, p. 43.

Dictionnaires Historiques, Nos. 842-5.

- Ecole des Chartes, Bibliotheque, Nos. 89, 177.

- Ecole des Chartes, Biblioiheque, Recueil de Facsimiles, No. 473 .

- Ecoles françaises d'Athenes et de Rome, Bibliotheque, No. 212.

Facsimiles, p. 53 .

Inventories of Archives, pp. 20-1.

Inventories of Local Records, pp. $37-8$.

Reines de, Lettres de, No. 905.
France, Rois de, Lettres de, No. gos.

- Ordonnances, No. 142.. Sources, pp. 145, is5-63.

States General, Nos. 1854. 1859, $1865,1871$.

States Provincial, No. 187a.

Franchises, pp. 83, ato-6.

Francis, G. C. Seath Charters, No. 1329.

- Swansea Chariers, No. 1333.

Franciscans, No. 26r5.

Francke, O. Verfestungsbuch, No. 1588.

Frankish Colonies of Syria, No. 2059 .

Franklin, A. Corporations ouv. rieres, No. 2393.

- Dictionnaire historique, Nos. 8+5, 2391.

Vie Privee, No. 2774.

Frankpledge, Nos. 1913, 2340. 2343.

Fraser, S. Reports of Proceed. ings, No. 1120.

Fraser, W. Liber S. Marie de Dryburgh, No. 1254.

Freeholders, No. 224 .

Freeman, E. A. Historical Geography, No. 6 g6.

- House of l.ords, No. 1856.

Methods of Historical Study. No. 365 .

_- Norman Conquest, No. 1739.

___ Teutonic Conquest, No. 1697.

_ William Rufus, No. 1740.

Freiburger historische Studien, No. 2616.

French Dictionaries, Nos. $385-98$.

French Rolls, Nos. 866, 871, 894.

Fretton, IV. G. Charterhouse. No. 2638.

- Fullers ${ }^{\circ}$ Guild, No. 2493.

Whitefriars, No. 2637.

Fréville de Lorme, C. E. de. Grandes Compagnies, No. 1820.

_ Mémoire, No. 2393.

Friars, Nos, 2617-9, $2711,2725$.

Friedlein, G. Die Zahlzeichen, No. 1957.

Fris, V. Schets van den economischen Toestand van Vlaanderen, No. 2019.

Froude, J. A. Short Studies, No. 366. 
Fruin, R. Repertorium, No. Iro.

Fuchs, C. J. Untergang des Bauernstandes, No. 2217 .

Fugger, Nos. 2030, 2068.

Fuller, E. A. Cirencester, Nos. $1150,2218,2295$.

— Tallage, Nos. I044, $195^{8}$.

Fuller's Gild, No. 2493.

Fulton, T. W. Sovereignty of the Seas, No. 1821 .

Fumagalli, G. Bibliotheca, No. 328.

Funck-Brentano, F. Philippe le Bel, No. 2020.

Funk, F. X. Geschichte des kirchlichen Zinsverbotes, No. 3010.

_-Ueber die ökonomischen Anschauungen, No. 3009 .

- Zins und Wucher, No. 3008.

Furness Abbey, Nos. I121, 2644.

Furniture, p. 64, Nos. $347,2865$.

Furnivall, F. J. Caxton's Book of Curtesye, No. 2777 .

- Chaucer, No. 1771 .

- Chaucer's Prioress, No. 2882 .

Education, No. 2776.

Manners and Meals, No. 2775.

- Robert of Brunne's Handlyng Synne, No. 1235 .

- Wills, p. I17.

Fustel de Coulanges, N. D. Institutions Politiques, No. 2134.

— Propriété Fonçière, No. 2135.

Gachard, L. P. Archives de la Belgique, No. 184.

- Archives du Vatican, No. 213.

- Cartulaires conservés en Belgique, No. 185 .

- Collection de Documents, No. 1480.

Notices des Comptes, No. 186.

_ Tableau Synoptique, No. I 87.

Gafol, No. 1983.

Gairdner, J. Henry III., No. 1742.

- House of Lords, No. 1859 . Lollardy, No. 1741.

Gale, P. Ancient Corporate System of Ireland, No. 1317.

Galy, C. La Famille, No. 2782.
Gams, P. B. Series Episcoporum, No. 661 .

Gand. See Ghent.

Gardiner, S. R., Bibliography of, No. I 44.

Gardner, J. S. Armour, No. 621.

Gareis, C. Kaiser Karls des Grossen capitulare, No. 2296.

Garnier, J. Cartulaires, No. 1362.

Garnier, R. M. British Peasantry, Nos. $2137,2704$.

- English Landed Interest, Nos. $2136,2705$.

Garreau, L. L'état Social, No. 2778.

Gascon Rolis, Nos. 866, 868.

Gascony, Castles, No. 1828 .

Gaskin, R. T. Whitby, No. 2449.

Gasquet, F. A. Black Death, No. 2981.

2547.

English Scholarship, No. 2780 .

- Greater Abbeys. No. $5^{87}$.

- Henry III. No $255^{8}$.

- Layman, No. 2578.

- Monastic Scriptorium, No. 448.

Montalembert's Monks of the West, No. 2537.

__ Old English Bible, No. 2548.

_- Parish Life, Nos. 2579, 2779.

Gatfield, G. Guide, No. 687 .

Gautier, L. La Chevalerie, No. 2706.

Gavelkind, Nos. 2245, 2249, 2260, 2262.

Gavet, G. Sources, p. I3.

Gay, E. F. Inclosures, No. 2297.

- Inquisitions of Depopulation, No. 2298.

Gazetteers, p. 70.

Geldersen, V. von. Handlungsbuch, No. 1593.

Genealogy, pp. $65-8$.

- Bibliographies of, p. 8.

Geneva, No. 2520.

Genoa, Nos. 794, 796.

Geoffrey de Mandeville, No. 1756. Geography, pp. 68-70.

Bibliographies of, p. 8.

George, E. F. Roman Fulling, No. 2944.

George, H. B. Archers at Crecy, No. 1822 . 
Geraud, H. Paris, No. 1474.

Gerlach, O. Finanzwissenschaft. No. 1978 .

Germain. A. Le Grand et le Petit Thalamus. No. 1455.

Gernain, A. C. Commerce de Montpellier. No. 2394.

German Women, No. 2894.

Germans, No. 2784.

Germany, Works relating to, Nos. $831-5,838,1613,1996$, $2000,2013,2032,2034,2069$. $2072,2085,2087,2099,2104$, 2144, $2181-3,2194,2198,2217$. 2307, 2346, 2352, 2353, 2354 , 2362, 2458, 2462, 2465,2539 , $2605,2849-51,2899,2941,2967$. $2968,2983,2984,3018$.

_ Bibliographies, p. I0, No.

24.

Facsimiles, p. 54 .

Inventories of Archives, pp. 23-5.

Inventories of Local Records, p. 39.

- Sources, pp. 166-73.

Gesiths, No. 2715.

Gheldolf. A. Warnkoenig's Histoire de la Flandre, No. 781.

Ghent, Nos. 2468, 2523.

Gibbins, H. de B. Industry, No. 2299.

Gibbons, A. Ely Episcopal Records, No. 252.

— Lincoln Wilis, No. 1146.

Gibbs, V. G. E. C.'s Complete Peerage, No. 654.

Gibson, S. Oldest Account Book, Nos. 1175, 2665.

Gierke, $O$. Deutsche Genossenschaftsrecht, No. 2462.

- Political Theories, No. 3011.

Giesebrecht, W. Geschichte der deutschen Kaiserzeit. No. 784.

Gilbert, D. Cornwall, No. 2950.

Gilbert, J. T. Ancient Dublin Records, No. 1294.

- Cartularies of St. Mary's Abbey, No. 8306.

— "Crede Mihi," No. 1295.

Facsimiles, p. 19

Gormanston Register, No. 1300.

Historic and Municipal

Documents, No. 1307.

Gilbertines, Nos. 2620-3.

Gilds, pp. 233-7. See Guilds.
Gild Regulations, Germany, pp. 178.2.

Gimont, Cartulaire de, No. 1375.

Giraldi Cambrensis Opera, No. 1339.

Giraud, C. Droit Irançals, No. 1885.

Giry, A. Cholx de Documents, No. 1467 .

- Fitabliswements de Rouen. No. 1451.

- Manuel, Nos. \$1, 497.

Giuseppi, M. S. Alien Merchants. No. 2021.

Glamorgan, Nos. 1327, 2287.

Glanville, R. de. Treatise, No. 1053.

Glaskow, Nos. 1256, $1270,2425$.

- Hunterian Museum. Cata. logue of Manuscripts. No. 298.

Glass, p. 65.

Glasscock, J. I.. Bishop" Stortford, No. 1893.

Glasses, No. 2494.

Glastonbury, Inquisition, No. 1161.

- Rentals, No. 1162 .

Glazier, R. Historic Ornament, No. 614 .

Gloucester, No. 2645 .

Monastery of St. Peter's, Nos. $1179,2303$.

Records, Nos. 254, 2068, 1122.

Gloucestershire Aid, No. 977.

— Domesday, No. 2330.

_- Inquisitions, No. 967n.

_ Pre-Domesday Hide of, No. 2331.

Subsidy Rolls, No. 1024.

Gloves, Nos. 2495, 2751.

Gneist, R. von. English Parliament, No. 1857.

Goddard, C. V. Winterbourne Stoke, No. 2219.

Godefroy, F. Dictionnaire, No. $3^{87}$.

I.exique, No. $3^{38}$.

Godwin, H. Archacologist's Hand-book, No. $5^{6}$.

Gold Rocks, No. 2947.

Goldschmidt, L. Handbuch, Nos. 744, 3012.

Goldsmiths, Nos. $2496,2498$.

Goller, F. Päpstliche Pönitentiarie, Nos. 1620, 2598. 
Gomme, G. L. Gentleman's Magazine Library, No. 727 .

- House of Lords, No. 1859.

__ Index, No. 30.

- Index (Annual), No. 31.

Local Institutions, No. 20.

. Tooting Beck Court Rolls, No. 1220.

- Village Community, Nos. $1698,2138$.

Widowhood Nos. 2220, 2883.

Gordon, G. Worcester Compotus Roll, No. II89.

Gormanston Register, No. 1300.

Görz, No. 1542.

Goslar, No. 1522.

Gosses, I. H. Stadsbezit, No. 2348.

Gotch, J. A. English House, No. 597.

Gothic Architecture, p. 61 .

Gottlob, A. Aus der Camera Apostolica, No. 2559.

- Päpstlichen Kreuzzugssteuern, No. 2560.

Gough, H. Camden Society Catalogue, No. 128.

.... Scotland, Nos. 1248, 1280.

- Heraldry, No. 688 .

Goyes, Eline, Jordeborg, No. i665.

Graesse, J. G. T. Orbis Latinus, No. 379.

Graffin, A. Biens Communaux, No. 2349.

Gragas, Logbok Islendinga nefnist, No. 1668.

Graham, R. Malton Priory, No. 2653.

- Saint Gilbert of Sempringham, No. 2620.

- Taxation of Pope Nicholas, No. $256 \mathrm{I}$.

Grammar Schools, No. 2755.

Grand, E. D. Paleographie, No. 42.

Grandinson, C. G. Studier, No. 2080.

Grant, J. Burgh and Parish Schools, No. 2783 .

Graves, J. Roll of King's Council, No. 1319.

Gray, A. St. Radegund's Priory, Cambridge, No. 2632.

Scottish Staple, No. 2094. Watercourse called Cambridge, No. 2929.
Great Council, Summons of Nobility to, No. 865 .

Great Cressingham Court Rolls, No. 1206.

Great Fen Road, No. 2962.

Great Seal, Writs and Letter under, pp. 86-9.

- of the Kings of the Scots, Register of, No. 1251.

Great Tey, No. 2200.

Green, A. S. Making of Ireland, No. 769 .

- Town Life, No. 2395.

Green, E. Bath Lay Subsidies, No. 1020.

— Bath Poll Tax, No. 999.

- Pedes Finium, No. ro71.

Green, J. R. Conquest of England, No. I699.

- Making of England, No. 1700.

Green, M. A. E. Letters of Royal Ladies, No. 903.

- Lives of Princesses, No. 662.

Green, IV. A. Ackworth, No. 2 I39.

Greenstreet, J. Assessments, No. $95^{2}$.

Lincolnshire Survey, No. 937.

Greenwell, W. Boldon Buke, No. 930.

Feodarium, No. 1160.

Hatfield's Survey, No. 1164 .

Green wich Hospital Records, p. 94 .

Gregorovius, T. Geschichte der Stadt Rom, No. 799.

Grey Friars, Nos, 2618, 264 I, 2664.

Grimaldi, Stacey. Rotuli de dominabus, No. 969 .

Grimm, J. Weistümer, No. 1570.

Grimston, No. 2243.

Grisar, H. Geschichte Roms, No. 800 .

Grocers, Nos. 2499, 2500.

Groningen, Nos. 1489, 1499.

Grose, F. Antiquarian Repertory, No. $278 x$.

— Antiquities, No. 562 .

Military Antiquities, No. 1823.

Gross, C. Bibliography of Municipal History, No. 121.

_ Coroner Rolls, No. 1093. 
Grosy, C. Court of Piepowder. No, 1886.

- Fixchequer of the Jews, Nos. 1887. 2097.

Gild Merchant, Nos. 117, 3463.

Sources, No. 84.

Town Records, No, 122.

Grosvenor, Robert, No, 1069.

Grotelend, H. Chronologie, No. 520.

Grove H. Alienated Tithes, No. 2594.

Gruchy, W. L. Grand Coutumier. No. 1454.

Grueber, H. A. Catalogue of Coins, No. 335.

Handbook, No. 547.

Grünberg, K. Bauernbelrejung, No. 2300.

Grundivig. J. Meddelelser, No. 1671.

Grupp, G. Kultur, No. $\mathbf{2 7 8 4}$.

— Kulturgeschichte, No. 752.

Guérard, B. Capitulaire, No. 1419.

1419. Cartulaire de l'Abbaye de

Saint Bertin, No. 1356.

Cartulaire de l'abbaye de Saint Victor de Marscille, No. 1355 .

Guerri, F. Corncto, No. 1631.

Guest, E. Early English Settlements, No. 1701.

- Origines Celticae, No. $17^{\mathrm{na}}$.

Guibal, G. Sentiment National, No. 2783 .

Guibert, L. I.ivres de Raison, No. 1470.

Guicciardini, L. Descrittione, No. 2022.

Guienne, Nos. 1732, 2007.

Guiffrey, J. Catalogue Sommaire, No. 170.

Guigue, C. Cartulaire municipule. No. 1366.

- Registres Consularies, No. $1+40$.

Guildev, J. M. Reading Records, No. 1136.

Guildford, No. $2+26$.

Guildhall, Catalogue of Antiquities. No. 343.

- Catalogue of Library, No. 9.

Guilding. J. M. Diary of Reading Corporation, No. 283 .
Guilds, Low Countrles, p. 163. See Gilds.

Guilhiermos, P. Les poids, No. $54^{3}$.

Guillois, A. Recherches, No. 1772.

Guizot, P. P. G. Histoire de Is Civilisation, No. az86.

Gundlach, O. IBbliotheca, No. 6.

Gunton, S. Peterborough Church, No. 2667.

Guppy, S. Clasuified Catalogue, No. 63.

Guthrie, E. E. Old Scottish Cus. toms, No. 2787 .

Guthrie, V. Classified Cata. logue, No. 63.

Gwatkin, H. M. Fssays on Teaching of History, No. 361.

Habsburgica Regesta. No. 1513.

Hachberg. No. isis.

Hackwood. F. IV. Good Old Times, No. 2790.

_ Inns, No. 2789.

Old Einglish Sport, No. $27^{88}$.

Hadley, A. T. Fincyclopiedia Britannica, No. 848.

Hahl, A. Zur Geschichte der volkswirtschaftlichen Ideen, No. 3013.

Hainaut, No. 1502.

- Cartulaire. No. 1478.

Halberstadt, Nos. $1523,1528$.

Hale, Sir M. De Jure Maris, No. 1912.

Hale, M. Custom of Goods, No. 1960.

- Sheriff's Accompts, No. 1959.

Hale, W. H. Domesday of St. Paul's, Nos. 1157. 2308.

Worcester Priory Register. Nos, $1191,2302$.

Hales Court Rolls, No. 1207.

Halkett, S. Advocate's Library Catalogue, No. 7.

Hall, R. G. Rights of the Crown in the Seashore, No. 1912.

Hall. H. Antiquities of the Ex. chequer, No. 1961.

- Court Life, Nos. 2791, 1773. 1962.

Crown Lands, No. alyo.

Formula Buok, Nos. iso, 499, 853, 870, 906, 921 , g5o. See I.ondon School of Economics. 
Hall, H. Pipe Roll, No. 1188, 2945.

Receipt Roll, No. 1009, 1963. See London School of Economics.

1964 .

Red Book, Nos. 925, 968,

System of the Exchequer, No. 1965 .

Studies, Nos. 15 I, 427, 498.

_ Welsh Records, No. 166.

Hall, J. R. C. Anglo-Saxon Dictionary, No. 401.

Halliday, C. Scandinavian Kingdom of Dublin, No. 770.

Hallischen Schöffenbücher, No. 1568.

Halliwell, J. O. Dictionary, No. 402.

Letters of Kings of England, No. 904 .

Halphen, L. Les Communes françaises. No. 2400.

- Paris, No. 2396.

- Recueil des Actes, No. 1424.

Hulyburton, Andrew, Ledger of, No. 1291.

Hamburg, Nos. 1524, 1553, 1578 , $2085,2088,2401$.

Hameln, No. 1525 .

Hamilton, N. E. S. A. Inquisitio Comitatus Cantabrigiensis, No. 927.

Hamilton, S. G. Hales Court Rolls, No. 1207.

- Worcester Compotus Rolls, No. I19o.

Hampshire, No. 1045.

Hampson, R. T. Kalendarium, No. 518.

Hampstead, No. 2149.

Hanauer, C. A. Paysans de l'Alsace, No. 2707.

Hancock, W. N. Ancient Laws, No. 1315.

Hannay, D. Navy, No. 1824.

Hanse Records, pp. 172-3.

Works relating to, pp. 207-8.

Hanseatic League, Influence on Architecture, No. $5^{83}$.

Hansen, G. Agrarhistorische Abhandlungen, No. 2141.

Hansische Geschichtsblätter, No. 204.

Hansische Pfingstblätter, No. 203.

Hansischer Archive Inventare, No. 205.
Häpke, R. Brügges Entwickelung, No. 2081.

Hardwick, No. 2132.

Hardy, B. C. Philippa of Hainault, No. 1743.

Hardy, T. D. Descriptive Catalogue, No. $255^{\circ}$

- Fine Rolls, No. I081.

- Index to Printed Reports of,

No. 154 .

- Itinerarium, No. I774.

- Prefaces, No. 500.

- Rotuli Chartarum, No. 856 .

- Rotuli de Liberate, No. 879 .

- Rotuli de Oblatis, No. 88r.

Rotuli Literarum Clausarum, No. 875 .

- Rotuli Literarum Patentium, No. 884 .

88 o.

Rotuli Normanniae, No.

- St. Albans School of

Writers, No. 449 .

- Syllabus, Nos. 897, 908, 15 I6.

Visits of Henry III., No. 1775.

Hardy, W. Charters of Duchy of Lancaster, No. 854.

Hardy, W. J. Doncaster Records, No. 1203.

- Handwriting, No. 428 .

- Rolls House, No. 152.

Hargrave, F. Hale's Treatise, No. Igfio.

Harland, J. Clitheroe Charters, No. 1108.

- Lancashire Documents, No. 1170.

- Mamecestre, No. 1172.

Harris, M. D. Coventry Leet Book, No. 120 r.

- Laurence Saunders, No. 2708.

— Old English Town, Nos. $2420,2792$.

Harrison, W. Ancient Fords, No. 2971.

Harrod, H. Goods and Ornaments, No. 2660.

- King's Lynn Deeds, No. $25^{8}$.

Hart, IV. H. Ramsey Chartulary, Nos. 1137.1180.

- St. Peter's, Gloucester, Chartulary, Nos. 1179, 2303.

Hartland, No. 2129. 
Hartog. G. A. Darmesteter's Grammaire Historique, p. 45.

Hartshorne, A. Old Finglish Glasses, No. 2494.

Hartshorne, C. H. Dumestic Manners, No. 2793.

- linerary, No. 1776.

Northumberland Antiquities. No. 1163 .

Hartung, J. Norwegen, No. 2032.

Harvey, A. Castles, No. 2350.

- English Church Furniture, No. 634 .

Hasbach, IV. Finglish Agricultural Labourer, No. 2142.

Haskins, C. H. Normandy, No. 2143.

Hassall, A. Handbook, No. 745.

Hasted, E. Kent, No. 709.

Hatfield's Survey, No. 1164 .

Hausen, R. Registrum, No. 1660.

Hausen, R. T. Bidrag, No. 1680.

Havard, H. Dictionnaire, No. 635.

Haverfield, F. Roads, No. 2969n.

_ Roman Britain, Nos. 563. 1703.

Roman Mines, No. 2951.

Havet, J. Compte, No. 1388.

Cours Royales, No. 1420.

Hawking, No. 2923.

Hawkins, E. Silver Coins, No. 549.

Hawstead, No. 2832.

Haxthausen, A. Agrarverfassung. No. 2144 .

Haydn, J. Book of Dignities, No. 663 .

Dictionary of Dates, No. 846.

Hazeltine, H. D. Gage of Land, Nos. $2221,3015$.

- Geschichte des Englischen P'andrechts, Nos. $1888,3014$.

Hazlitt, WV. C. Blount's Tenures, Nos. +15, 2222, 2753.

- Vivery Companies, No. 2464.

Heales, A. Kingston-uponThames Church, No. 2650.

Heales, A. C. Merton Priory, No. 2656.

- Tanridge Priory, No. 2674.

Healey, Sir C. E. H. Chadwyck. Somersetshire Pleas, No. 1073.

Hearne, Tr. Leland's Collectanca, No. $5^{67}$.
Hearne. T. Liber Niger, No. 957.

Hearnshaw. F. J. C. Court leet Records, No. 2373.

- I.eet Jurisdiction, No. 2337.

Heath, J. B. Worshipful Company of Grocers, No. 2499.

Hebrides, No. j65.

Hecker, J. H. C. Fipidemles, No. 29\$2. Trs.

lledges, J. K. Wallingford, No. 2448.

Hedon, No. 2427.

Hegel, K. Stadie und Gilden, No. 2465 .

Heilprinn, A. and L. I.ippencor's Gazelteer, No. 731.

Heins, M. La monnaje, No. 2523.

Heise, C. A. L. Diplomatarium, No. 1653 .

Henderson, E. Verbrechen und Serafen, No. 1889.

Henderson, G. Celtic Scotland, No. 2023.

Hennessy, G. Novum Repertorium, No. 2580.

Henry I., No. 1740.

Henry 11., No. 1738, 1770.

Henry III., Nos. 913, 1742, 1775. $1985,255^{8}$.

Henry IV.. Nos. 912, 1762.

Henry VI., No. 914.

Henry VII., Naval Accounts of, No. 1833,915 .

Henry, Earl of Derby, No. 1839 .

Hentsch. A. A. Litferature Didactique, No. 2885 .

Hepworth, No. 2131.

Heraldry, pp. 65-8.

- Bibliographies of, p. 8.

Herbert, J. A. Illuminated Manuscripts, No. $45^{8}$.

Herbert, W. Livery Companies, No. 2466.

Hereford, Nos. $1123,2428$.

_ Cathedral, No. 2588.

Episcopal Register, p. 117.

Herre, P. Quellenkunde, No. 77.

Herrtage, S. J. Catholicon, No. 403.

Tusser, No. 407.

Hertel, G. Hallischen Schöftenbücher. No. $156 \mathrm{~s}$.

Urkundenbuch, No. isa7.

Hertford. No. 707.

Hertford House, Wallace Collection, Catalogue of Armour, No. 344. 
Hertfordshire Domesday Tables, No. 2284 .

Hertrich, H. Théories Monétaires, No. 3or6.

Hertzberg, W. A. B. Libell of Englishe Policye, No. 1238.

Hervieu, R. Recherches, No. 1858 .

Herzfield, L. Handelsgeschichte, No. 2098 .

Hessels, J. H. Palæographical Publications, No. 43.

Hessisches Urkundenbuch, No. 1526.

Hettema, F. B. Een Bezoek, No. 235 t.

Hettler, A. Adress-Buch, No. 198.

Archivalische Almanac, No. 196.

- Archivalische Bibliographie, No. 197.

- Jahrbuch, No. 199.

Hewlett, H. W. Perambulations, No. 2912.

Hexham Priory, No. I 165.

Heyd, H. Levant, No. 746 .

Heyd, W. Beiträge, No. 831 .

Hibbert, F. A. English Gilds, No. 2467.

Hibbert-Ware, S. Cistoms of a Manor, No. 2223.

Hickes, G. Thesaurus, No. 501 .

Hidation, Nos. $2283,2325$.

Hidber, B. Schweizerisches Urkunden-Register, No. 1540.

Hide, Nos. 2319, 2331.

Hildebrand, C. Urkunden, No. J662.

Hildebrand, H. O. H. Industrial Arts, No. 2483 .

- Stockholms Stads Jordeborg, No. 1667 .

Hildebrand of London, No. 1017.

Hildesheim, No. 1529.

Hill, G. English Dioceses, No. 2549.

_ English Dress, No. 630.

Norman Invasion, No. 1744.

Hill, O'D. T. English Monasticism, No. 2550.

Hillen, H. J. King's Lynn, No. 2930.

Hilliger, B. Rheinische Urbare, No. 1549 .

Hinde, J. H. Newcastle, No. 2952 .
Hingeston, F. C. Letters relating to Wales, No. J331.

- Royal Letters, No. 912.

Hingman, J. H. De Maas, No. 2931.

Hinojosa, E. de. El regimen senorial, No. 2145.

Hirsch, J. Danzigs Handels-und Gewerbsgeschichte, No. 2083 .

Historical Association Leaflets, No. 133 .

Historical MSS. Commission, List of Reports, No. 256.

$1300,1312$.

Historical Method, pp. 44-5.

- Bibliography, p. 5 .

Historische Vierteljahrschrift, No. 96.

Hjaltalin, J. A. Advocates' Library Catalogue, No. 7.

Hoare, R. C. Wiltshire, No. 2374.

Hobhouse, Bishop. Churchwardens' Accounts, p. 121.

Hocking, W. J. Catalogue of Coins, No. 345 .

Hoddesdon, No. 2186.

Hodgetts, J. F. Anglo-Saxon Dress, No. 2796.

- English in the Middle Ages, No. 2795 .

- Older England, No. 2794.

Hodgkin, T. Political History of England, Nos. 815, 1704.

Hodgson, J. Northumberland, Nos. $710,2147$.

- Northumberland Pipe Rolls, No. 994 .

Hodgson, J. F. Eggleston Abbey, No. 2642.

Hodson, J. W. Hutchins's Dorset, No. 2368.

Hoefer, J. C. F. Nouvelle biographie générale, No. 689 .

Hoeniger, R. Kölner Schreinsurkunden, No. $153 \mathrm{I}$.

—- Schwarze Tod, No. 2983.

Hoffmann, M. Der Geldhandel, No. 2099.

Höhlbaum, K. Inventare, No. 205.

Holdsworth, W. S. English Law, Nos. $817,1890$.

Holmes, T. R. E. Ancient Britain, No. 1705 . 
Holmesfield Court Rolls, No. 1203.

Holland, Catalogues of Manu. scripts, No. 313.

Facsimiles, p. 54.

Works relating to, Nos. 1796, 2347, 2931, 2934.

Holland, H. H. King's Customs, No. 1943.

Holliday, J. R. Maxtoke Priory, No. 2655 .

Holmes, Sir J. Ancient and Modern Ships, No. 1825.

Holmes, 'T. F. R. Ancient Britain. No. 564.

Holize, F. Das Berliner Handelsreche, No. 2034.

- Die Berliner Handelsbes. teuerung, No. 2025.

Holtzinger, G. Catechismus, p. 23.

Holy Land, Hospitallers in, No. 2112.

Holy Rosman Empire, Histories of, p. it.

Hone, N.J. Manor, No. 21 6.

Hoorn, No. 2429.

Hope, IV. H. St. John. Abbey of St. Mary in Furness, No. 2644. Chronicles of All Saints. Derby, No. 1194, 2586.

- Rochester Cathedral, No. 2670.

Seals, Nos. 532-5.

Walton Priory, No. 2675.

Horne, A. Mirror of Justices, No. 1054.

Horsley. J. Britannia Romana, Nos. 565, 1706.

Horticulture, No. 2862.

Hospitals, No. 2978.

Hospitallers, Nos, $2112,2114$. Cartulary of Order, No. 1364.

- Inventories of Archives of Belgian Commanderies, No. 182 .

House, English, No. 2745.

Houtte, H. van, Civilisation Flamande. No. 2797.

Documents, No. 1503.

Howitt, W. Rural Life, No. 2798.

Howth. The Book of, No. 1305.

Hraber, V. F. De Legatis, No. 502.

Hubner, F. Römische Herrschaft, No. 1707.
Hudson, W. Abbot of St. Benet, No. 2304 .

- Assrament of Norfolk. No. 953.

Ieet Jurindiction, Not. 1215. $180) 1,2338$.

- Norwich Records, Nov. 113z. $23 \% 1$.

- Sussex Subsidies, No. 1038. -Three Manorial Foxtent, No. 3183 .

Hughes, A. English Currency. No. 1949.

Hugo, "T". Medianal Nunneries, No. 2887 .

Hulham Manor, No, a i (n)

llunber, lost Towins of the, No. 2377.

Humphrey. Duke of Cloucester. No. $176 \%$.

Hundred Kolls, Nos. 959, 1085.

Hundred Years War, Nos. 1746. 2020.

Hunt, R. British Mining. No. 2953.

Hune, W. English Church, No. 823 .

- Italy, No. 801.

Political History of England, Nos. 815. 1728.

Hunter. J. Dewsbury, No. 2640.

- Fines, No. 1082.

- Pipe Rolls, Nos. 1013, 1014.

- Robin Hlood, No. 2799.

Rotuli Selecti, Nos. 8S6. 1086.

Hunterian Museum. See Glas. gow.

llunting. pp. 263-4.

Hurley, St. Mary's, No. 2646.

Hussey, A. Wills, p. 117.

Hutchins, J. Dorset, Nos. ist, 2365.

Hutchinson, L. Oriental Trade, No. 2026.

Huvelin, P. Essai historique, No. 2525 .

- Travaux récents, No. $202 \%$

Huyttens, J. Corporations Gantoises. No. 2468.

Iceland, No. 2762.

- Islandicac Origines, No. 1682.

Islendinga l.ogbok, No. 1668.

Icelandic Sagas, No. $168_{4}$.

Ihm, M. Lateinische Papyri, No. 44. 
Ilchester Almshouses Deeds, No. 1124.

Ilger, C. Antonin von Florenz, No. 3017 .

Ilger, T. Rheinisches Archiv, p. 24.

llkley Court Roll, No. 1209.

Illingworth, W. Placita de quo warranto, Nos. 963, 1084 .

Illuminations, p. $5^{2}$.

_- Bibliography of, No. 39.

Imbart de la Tour, H. D. Liberté commerciale, No. 2028.

Immigrants, Alien, No. 2694.

Inama-Sternegg, K. T. von. Deutsche Wirtschaftsgeschichte, No. 832 .

Inchaffray Charters, No. 1273 .

Inclosures, Nos. 2297, 2298, 2309 , $2310,2315,2328$.

Inderwick, F. A. King's Peace, No. 1892.

Indulgences, pp. 243-4.

Ingoldmells, Accounts, No. I 166 .

- Court Rolls, No. 1210.

Inman, A. H. Domesday, No. 2305.

Innes, C. Acts of Parliament, No. 1283 .

- Ancient Laws, No. 1286.

Andrew Halyburton's Ledger, No. 1291.

Liber S. Marie de Calchou, No. 1257.

- Liber S. Marie de Melros, No. $125^{8}$.

- Liber S. Thome de Aberbrothoc, No. 1253.

- Originales Parochiales, No. 712.

Registrum de Dunfermelyn, No. 1255 .

Registrum Episcopatus Aberdonensis, No. 1266.

Registrum Episcopatus Glasguensis, No. 1256.

- Registrum S. Marie de Neubotle, No. 1260 .

- Scotch Legal Antiquities, No. 1893.

- Scotland, No. 764 .

Inns, No. 2789.

Inquisition in France, No. 2536.

Inquisitions, pp. 95-9.

- ad quod damnum, No. 961.

— Ecclesiastical, p. 99.

—_ Feudal, pp. $98-9$.
Inquisitions, Fiscal, p. 98.

- France, p. 159.

- Post Mortem, p. 96, No. 967.

- Post Mortem, Duchy of Lancaster, No. $95^{8}$.

-Welsh, No. 1330.

Inspeximus, p. 84 .

Instituto Storico Italiano, No. 325 .

Interdict, No. 2565 .

Interludes, No. 2836.

Inventaires imprimés, No. 136.

Inventare Oesterreichischer Staatlicher Archive, No. 206.

Inventare Sch weizerischer Archive, No. 209.

Inventories, p. 118 .

- of Diocese of Dublin, No. 1296.

Ipswich, No. 2430.

Wills, No. 257. Great Domesday, No. 931.

Ireland, Bibliographies, p. Io.

Catalogues of Museums, $p$. 42.

Inventories of Archives, p. 19.

- Manuscript Materials of Irish History, No. 299.

- - Sources, pp. 136-40.

- Topographical Dictionary of, No. 730.

Works relating to, p. 73, Nos. 1753, $2118,2236,2361$, 2718, 2874 .

Irish Record Commission Publications, Nos. $1297-9$.

Iron, Nos. 2954, 2957.

Iron Age, Guide to Antiquities of, No. 340 .

Ironmongers' Hall, Catalogue of Antiquities, No. $35^{\circ}$.

Ironmongers, Worshipful Company of, Nos, $2501,2502$.

Irvine, Muniments of, No. 1263.

Irvine, W. F. Wills, p. II7.

Isabel II., No. I641.

Isabella, Queen of Edward II., No. 1765 .

Isambert, F. Recueil général, No. 1421 .

Isnard, M. Z. Cartulaire, No. 1367 .

Comptes, No. 1407 .

Istrien, No. 1542.

Italian Communes, No. 2167. 
Italian Merchants, Nos. 869, 986, 2004.

- States, Histories, p. 75.

- Sources, pp. 176-7.

Italy, Bibliographies, p. I1, Nos. $123-4$.

- Facsimiles, p. 54 .

- Inventories of Archives, pp. $25-6$.

- Inventories of Local Records, p. 39.

- Libreria Italiana, Catalago, No. 22.

- Works relating to, Nos. 2069, 2073, 2344, 2690, 2875 . 3022.

Itinerant Justices, Somersetshire Pleas, No. 1073.

Ives, G. C. Penal Methods, No. 1894.

Ivoi Carignan, No. 1461.

Izern, E. Roi de Navarre, No. 1390.

Jacob, G. Der nordisch-baltische Handel der Araber, No. 2029.

- Law Dictionary, Nos. 418. 847.

Jacob, J. Bibliotheca AngloJudaica, No. 134.

Jacobs, J. Jews, Nos. $2100,2709$. London Jewry, No. 2 tor. Papers on Jewish History. No. 2710.

Jackson, C. J. English Goldsmiths, No. 2498.

Jacquerie, Nos. $2684,2716$.

Jaffé, P. Bibliotheca, No. 1506.

- Regesta, No. 1607.

Jahresberichte, No. 99.

Jal, A. Archéologie, No. 1826.

James, J. Worsted Manufacture, No. 2518.

James, M. R. Bury St. Edmunds, No. 2631.

- Catalogues of MSS., Cambridge Colleges, Nos. $236-46$.

_ Eton College, No. 253.

_- Lambeth Palace, No.

272.

No. 291.

Westminster Abbey,

Janicke, K. Urkundenbuch, Nos. $1529,1536$.

Jansen, M. Die Anfänge der Fugger, No. 2030.

Janssen, J. Geschichte des deutschen Volkes, No. 3018.
Jarrett, B. Black Friars, No. 2652.

Jary, E. ron. Cartulaire, No. 1358.

Jastrow, J. Die Volkrahl deut. scher Sthide, No. 2984.

Jeallreson, J. C. Lelcester Horough Manuscripts. No. 259. Jean de Vienne, Amiral de France, No. 1840 .

Jean le Bel, Chronique, No. 917. Jean, Roi, Rançon de, No. 1394. Jeanion, G. Servage. No. 2zs4. Jeayes, J. II. Berkeley Castle Charters, No. 230.

- Derbyshire Charters, No. 249.

Jenkins, R. Papermaking, No. $4+3$.

Jenks, E. Law and Politics, No. 3019.

Jenner, 11. Farly Drawings, Nos. 39. 457.

Jensen, O. Denarius Sancti Petri. No. 2562.

Jesse. G. R. British Dog, No. 2922.

Jessop, A. Beeston Priory, No. 2628.

Before the Great Pillage, No. 2581 .

- Coming of the Friars, Nos. 2582, 2711.

- The Land, No. 2148.

Jewish History, Bibliographies, Nos. 134, 143.

Jewish Life, No. 268 I.

Jewitt, L. Ancient Customs, No. 2800.

Jews, Sources, Nos. 920, 936, 1097.

Works relating to, p. 209. Nos. 1887, 2709

Joint Stock Companies, No. 2065.

John Crerar Librasy, List of Bibliographies, No. 37.

John. King of England, No. 1774.

John of Gaunt, No. 1729.

John of Harnham, No. 1017.

John of Oxford, No. 1200.

John Rylands Library, Sce Manchester.

Johnson, A. H. Small Landholder, No. 2306.

Johnson, C. Exchequer Chamber, No. 1966. 
Johnson, R. Hereford, Nos. 1123 , 2428 .

Johnstone, H. State Trials, No. I099.

Jones, D. Brynmor. Criminal I a w, No. 1896.

— Welsh Laws, No. I895.

Jones, J. I. Cardiff Free Library Catalogue, No. 5 .

Jones, L. Churchwardens' Accounts, p. 122 .

Jones, W. H. Episcopate, No. 2563.

WViltshire Domesday, No. 950.

Jordan, H. E. Local History, No. 125.

Jordell, D. Repertoire, No. 25.

Jourdain, A. L'Education des Femmes, No. 2884.

Jourdain, C. Economie Politique, No. 3020 .

- Marine Militaire, No. 1827.

Jourdan, A. Recueil général, No. 1421.

Joyce, P. W. Short History, No. 771 .

Social History, No. $77^{2}$.

Jubainville, H. D. Arbois de, Abbayes Cisterciennes, No. 2614.

Judges, No. 659.

Judicial Proceedings, Empire, pp. $170-1$.

—_- England, pp. ıо6-го, $122-5$.

- France, pp. 159-60.

- - Ireland, pp. 139-40.

— L Low Countries, p. 165.

- Scotland, p. I35.

-Wales, pp. 143-4.

Jupp, E. B. Worshipful Company of Carpenters, No. 2488.

Jury, Trials by, No. 1933.

Jusserand, J. A. A. J. English Wayfaring Life, Nos. 697, 2801.

- Les Sports, No. 2802.

Justiciary Rolls, Ireland, No. 1323 .

Kalischer, E. Beiträge, No. 203 I.

Kärnten, No. 1542 .

Karslake, F. Notes from Sotheby's, No. 135 .

Kautsky, K. Vorläufer des neueren Sozialismus, No. $2 \mathrm{So}_{5}$.

Keary, C. F. Dawn of History, No. 566 .
Keary, C. F. English Coins, No. 335 .

... Vikings, No. I 708 .

Kehr, P. Papsturkunden, No. I $60 \mathrm{I}$.

Kchr, P. F. Regesta, No. 1609.

Kelham, R. Britton, No. 1047.

- Norman French, No. 389.

Keller, WV. Angelsächsische Palaeographie, No. 429.

Kelso Abbey, Liber S. Marie de Calchou, No. 1257.

Kemble, J. M. Codex, Nos. 503, I I 10.

Saxons, Nos. $1709,2712$.

Kemeys, Baronia de, No. 1334.

Kennedy, J. Hampstead, No. 2 I 49.

Kennett, IV. Bernwode Forest, No. 2913.

- Parochial Antiquities (Glossary), No. 419.

Kent, Nos. 2214, 2245, 2249.

- Archæological Society, Collections, Catalogue of, No. 351.

—_ Wills, p. 117.

Assessment in, No. 952.

- Common Law of, No. 1928.

— Domesday Book of, No. 932.

— Eyre of, No. 1095 .

- History of, No. 7og.

Kenyon, R. Hasbach's English Agricultural Labourer, No. 2142.

Kenyon, R. L. Gold Coins, No. $55^{\circ}$.

Silver Coins, No. 549 .

Kerly, D. M. Court of Chancery, No. 1897.

Kerry, C. Baslow Court Rolls, No. 1199.

- Bridge Chapels, No. 2972.

- Holmesfield Court Rolls, No. 1208.

- Peak Forest, No. 2903.

Kershaw, S. W. Ancient Bridge Chapels, No. 2973.

Lechlade Bridge, No. 2974.

Kervyn de Lettenhove, Baron H. M. B. L. Flandre, No. 778.

Kettering Compotus, No. 1167.

Keussen, $\mathrm{H}$. Inventare Hansischer Archive, No. 205.

Keutgen, F. Aemter und Zünfte, No. 2469 .

- Hanse, No. 2084. 
Keutgen, F. Untersuchungen, No. 2352.

Urkundann, No. 15i4.

Key. E. Colonies Iranques, No. 2059.

Kevser, C. E. Painted Decora. tions, No. 643.

Keyser, J. R. Old Northmen, No. $2 \mathrm{SO}_{3}$.

Keyser, R. Norges gamle Love. No. 1685 .

Kirsselbach, G. A. Wirtschaft. lichen Girundlagen, No. zo8s.

King, J. Irish Bibliography, No. 87.

Kingdon, J. A. Grocers of Lon. don, No. 2500.

King's Bench Court, Pleas, No. 1074 .

King's Council, No. 1863.

King's Council in Ireland, Roll of, No. 1319.

King's Court, Rolls of, Nos. 1075. 1078 .

_- Pleadings in, p. 108.

France, Nos. 1427,1428 .

King's Craftsmen, No. 2487.

Kings of England, Letters of, No. 904.

Wills of, No. 1145 .

King's Lynn, Nos. 2431, 2647. 2930.

No. 258.

Kingsford, C. L. London, No. 2436.

Kingston-on-Hull Charters, No. 1125.

Kingston-upon-Thames, No. 2650.

Kingswood Forest, No. 2900.

Kirby, T. F. Winchester College, No. 2804.

Kirkby's Inquest for Yorkshire, No. 956.

Kirkby's Quest, No. 966.

Kirchenlexicon. No. 851.

Kirklees Priory, No. 2649.

Kirkstall Abbey Rent Roll, No. 1168.

Kirsch, J. P. Chambre Apostolique, No. 2564.

_ Päpstlichen Kollektorien, No. 1613 .

Kitchin, G. W. Christchurch, Oxford, Library Manuscripts, No. 279.
Kitchin, G. W. Charter of Ed. ward III., Nos. IIf1, agat.

Winchester Cathedral Char. ters, No. 1141.

Kitchin, W. Fi. Manydown, No. 1174 .

Klump. W: Altenglisechen Hand. werkernamrn, No. 420.

Knapp, G. F. Bauernbelrelung. No. 2307.

Knight wervice, Nos. 1944, 2261.

Knights Hospitallers, No. 116n. See Hospitallers.

Knights of lingland, No. 673.

Knipping, R. Die Kölner Stadı. rechnungen, No. 1555.

Knült, B. Historische Geogra. phie, No. 2967.

Koch. H. Richard von Cornwall, No. 1745 .

Koehler, (3. Die Entwickelung des Kriegswesens. No. 785 .

koenen, H. J. De Nederlandsche Boerenstand, No. 2150.

Koppmann, $k$. Johann Tölners Handlungssbuch, No. 1591.

L L citladen, No. 1587 .

Korn, G. Schlesische Urkunden, No. 1580 .

Kötzsckhte, R. Deutsche Wirtschaftsgeschichte, No. 833 .

Kovalevsky, M. Die ökonomische Entwickelung Europas, Nos. $834,2308$.

Krain, No. 1542.

Kramer, S. English Craft Gullds. No. 2470.

Krarup, A. Acta Pontificum Danica, No. 1652.

Krehbiel, E. B. Interdict, No. 2565.

Krehbiel, H. E. Fine Art, No. 68.

Kretschmer, K. Historische Geographie, No. 608 .

Kunze, K. Hanseakten, No. $15^{84}$.

Kuntzel, G. Verwaltung, No. 2032.

Kurth, G. Cite de Litge, No. 2434.

Notger de l.ikge, No. 2806.

Kuske, B. Das Schuldenwesen, No. 2333.

Laborde, I.. de. Dues de Bour. gogne, No. 2033.

Cilossaire Irançaise, No. 390.

Labourers, Stature of, Nio. 1926. 
Lackford Hundred, Suffolk, Subsidy Rolls, No. 1026.

Lacock Abbey, No. 2651 .

Lacombe, P. Bibliographie de Leopold Delisle, No. $13 \mathrm{I}$.

Lacroix, P. Arts, No. 615.

L Le Moyen Age, No. 2844 .

Lafontaine, H. C. de. King's Musick, No. 1777 .

Laing Charters, No. 1264.

Laing, H. Scottish Seals, No. 536.

Laking, G. F. Armour in Wallace Collection, No. 344 .

Lallemand, L. Charité, No. 3021.

Laloire, E. Belgian Archives, p. 2 I.

21. Tableau Synoptique, No. 188.

Lambert. Régime Municipal, No. 2397.

Lambert, J. M. Gild Life, No. 2471.

Lambeth Palace Library Manuscripts, No. 272.

Lamond, E. Walter of Henley, No. 391 .

Lamprecht, K. Deutsches Städtewesen, No. 2354.

- Deutsches Wirtschaftsleben, Nos. $\$_{35}, 2034$.

Moderne Geschichtswissenschaft, No. 368.

Lanark, Records of, No. 1265.

Lancashire, No. 2369.

- and Cheshire Historical Society, Wills, p. 117 .

- Bridges, No. 2971.

- Danes in, No. 1715.

- Documents, No. I I 70.

- Manors of Henry de Lacy, Compoti of, No. 1156.

- Inquisitions Post Mortem, No. $967 n$.

- Pipe Rolls, No. 993.

- Subsidies, Nos. 1027-8.

Lancaster Court Rolls, No. I2II.

- Duchy of, Charters, Nos. $854,862,89 \mathrm{r}$ :

- Inquistions Post Mortem, No. $95^{8}$.

- Privy Seals, No. 911 .

Lancaster, Thomas, Earl of, Court Rolls of, No. 12II.

Lancaster, IV. T. Thorner Court Rolls, No. 1219.

Land Charters, No. 1126.
Land Laws, Nos. 1923, 2242.

Landed Interest, No. 2705.

Landor, W. N. Alrewas Court Rolls, No. 1198.

Landry, A. Essai, No. Soz.

Lange, C. C. A. Diplomatarium, No. 1659.

Langebeck, J. Scriptores, No. 1678 .

Langlois, C. V. Archives, No. 174.

Chancellerie Royale, No. 1794.

Connaissance de la Nature, No. 2807 .

- Doléances, No. 1416 .

_ Etudes Historiques, No. 369 .

- Manuel, No. 91.

_- Robert Mignon, No. 1398.

- Rouleaux d'arrêts, No. 1427.

— Société française, No. 2808.

- Vie en France, No. 2809.

Lappenberg, J.M. Hamburgisches Urkundenbuch, No. 1524 .

- History of England, No. 1710.

Urkundliche Geschichte, Nos. $1586,2086$.

Lapsley, G. T. Cornage, No. 2225.

Durham, No. 2151.

Fifteenth Century Ironmaster, No. 2954.

Flemings, No. 2036.

Origin of Property in Land, No. $215^{2}$.

Larchey, L. Dictionnaire, No. 392.

Larking, L. B. Domesday Bock of Kent, No. 932.

Knights Hospitallers, No. 1169.

Larson, L. M. King's Household, No. 1778 .

La Sorsa, S. L'Organizzazione, No. 1633 .

Lassberg, F. L. A. von. Der Schwabenspiegel, No. ${ }^{1569 .}$

Lasteyrie, R. de. Album Archéologique, No. 357 .

- Bibliographie générale, Nos. 29,64 .

Cartulaires, No. 1365 .

Latin Dictionaries, pp. 46-7.

La Tremoille, Duc de, No. 1411 .

_- Les la Trémoilles, No. 1412.

L Livre de Guy de, No. 1411 . 
Lattes, A. II diritto commerciale, No. 3022 .

- II diritto consuetudinario. No. 3023 .

Laurent, C. Statuts, No. 1461.

I.aurent, J. Cartulaires, No. 1360.

Lauzun, P. Chateaux Gascons, No. 1828 .

Laverridre, J. Recherches, No. 2332.

Lavisse, E. Album Historique, No. 63 t.

Histoire de France, p. 13. No. 777.

Law, A. English Nouveaux Riches, No. 2783 .

Law, T. G. Manufacture, No. 2035.

Law Courts, pp. 193-7.

Dictionary. No. 847.

Merchant, No. 1910 , p. 806.

- Society Library Catalogue, No. 10.

Lawrence, H. History of Women, No. 2888.

Lawrie, A. C. Scotsish Charters, No. 1245 .

Laws, Empire, pp. 170-1.

_ England, p. 107.

- France, pp. 159-60.

— Ireland, No. 1315.

- Maritime, No, 1430.

Wales, Nos. $1340-8$.

Lazard, L. Juifs, No. 2103.

Lea. H. C. Auricular Confession, No. 2602.

Papal Penitentiary, No. 2599.

- Superstition, No. 1898 .

Leach, A. F. Education of Women, No. 2881 .

Educational Charters, No. 1127.

- Yorkshire Schools, No. 2810.

Leadam, I. S. Bondage, No. 2227.

Copyholders, No. 2228.

Domesday of Enclosures,

No. 2310.

Inquisitions of 1537. No. 2309 .

Inquisitions of Depopulation, Nu. 2298.

- Star Chamber Cases, No. 1899.

Villainage, No. 2226.

Learned Societies, Bibliographies of, p. 4 .
Learnnd Societies, List of $\mathrm{pp}$. 273-80.

- Year-book of, No. 34.

leathernellers. Worahiplul Com. pany of. No. 2go3.

Leathes, I'. H. Charter of Fix. emption, No. 3914.

I.echande D'Anisy, A. L. Foxirale des Chariew. No. 3os.

Cirands Koles, No. $13^{9} 3$.

techlade Bridge, No. 9974.

Lecoy de la Marche, A. Comptes du Roi kene. No. 1397.

- Les Sceaux, No. 537.

- Societt, No. 2811 .

Lederede, Bishop Richard, Taxa. tion. No. 1312.

I.ee, F. G. Churchwardens' Accounts, p. 122.

I.e. S. Dictionary of Nationat Biography. No. Goo.

Leeds, No. 2432.

l.ees. J. C. Paisley Abbey, No. 2666.

Leet Juriediction, Nos, $2337-8$.

Lelevre, E. Tableau Synoptique. No. 188.

Legal History, p. 76 .

Libliographies, p. 12.

tehfeldt, T. A. Pollen' Furniture, No. 638.

I.ehman, P. Vorlesungen, No. 439.

Leicester, No. 2433.

Borough Records, Nos. 260. $1128,1212$.

- Index to Ancient Manu. scripts, No. 259.

- History of, No. $7: 6$.

Leicestershire Surver, Nos. 933-5. Subsidy Roll, No. 1029.

Leigh, Iancashire, Subsidy Roll, No. 1030.

Lekszycki, J. von. Die alttesten kross-polnischen Grodbucher. No. 1567 .

Leland, J. Collectanea, No. 567.

L Itinerary, Nos. 568, 699.

Lelewel, J. Gtographie, No. 7oo.

Lelong. F. Rtpertoire, p. ing.

Lemaire, F. Livre Rouge, No. 1459.

Ler.saire. G. Archives de Saint Quentin, p. 21.

Le Moven Age, No. 79.

Le Neve, P. Fasti, No. 664.

Lennel, F. Calais, No. 2415 . 
Leonard, G. H. Jews, No. 2102.

Lépicier, A. M. Indulgences, No. 2603.

Lérins, Cartulaire de, No. 1374.

Le Roulx, J. Delaville. Les Hospitaliers, No. 2 II2.

Les Archives Belges, No. 114.

Le Scrope, Richard, No. 1069.

Lesne, E. Propriété ecclésiastique, No. $25^{89}$.

Lespinasse, $R$. de. Le Livre des Métiers, No. 1463 .

Lethaby, W. R. London, No. 2437. Mediæval Art, No. 616.

Westminster Abbey, Nos. $588,1808,2487$.

Letters, pp. 91, II8, Nos. 914, 915, I33I.

- under the Great Seal, pp. 86-9.

- under the Smaller Seals, pp. 89-93.

Levant, No. 746 .

Levasseur, E. Classes ouvrières, No. 2714.

Lewis, D. Court of President and Council of IVales, No. 1900.

Lewis, E. A. Decay of Tribalism, No. 2153.

Welsh Records, p. 19.

Lewis, G. R. Stannaries, No. 2955 .

Lewis, H. Ancient Laws, No. 1343.

Lewis, S. Topographical Dictionaries, Nos. 728-30.

Liberate Rolls, Nos. 869, 879, 986.

Liberties, p. 84 .

Charters of, No. 1048.

Library Catalogues, pp. 2-3.

Libres Prêcheurs, No. 2821 .

Lichfield Muniments, No. 26r.

Liebermann, F. Gesetze, No. 105 I.

Leges Anglorum, No. 1903. Leges Edwardi Confessoris, No. I901.

- Pseudo-Cnuts Constitutiones de Foresta, Nos. 1902, 2915.

- Quadripartitus, No. 1057.

Liège, Nos. 2434, 2456, 2806.

Liesegang, E. Niederrheinisches Städtewesen, No. 2398.

Liliencrow, Baron R. von. Historischen Volkeslieder, No. 1597.

Liljegren, J. G. Svenskt Diplomatarium, No. I663.
Lille, No. 1453, 2390.

Limerick, Black Book of, No. 1301.

Limoges, Registres, No. 1439.

Limousin, No. 1470 .

Lincoln Diocese, Subsidy, No. 972.

- Episcopal Register, p. 117.

- Royal Charters, No. 262.

- Wills, No. I146.

Lincolnshire, Nos. 1723, 2935.

— Domesday Book, No. 936.

- Inquisitions Post Mortem, No. $96 ; n$.

- Sokemen, Nos. 2235, 2719.

- Survey, No. 937.

Lindbalk, J. Acta, No. 1652 .

Linden, H. Gildes Marchandes, No. 2472.

Lindner, T. Deutsche Hanse, No. 2087 .

Lindores Chartulary, No. 1274.

Lindsay, J. Coinage, No. 551.

- Inchaffray Charters, No. 1273.

Lindsay, W. M. Contractions, No. 463 .

- Irish Minuscule Script, No. 430.

Lindsay, W. S. Merchant Shipping, No. 2509.

Lindsey Survey, No. 938.

Lingelbach, W. E. Merchants Adventurers, No. 2037 .

Linguistic, pp. 46-50.

Lippincott's New Gazetteer, No. 731.

Lipscomb, G. Buckingham, No. 713.

Litchfield, F. Furniture, No. 636 .

Literary Manuscripts, pp. 125-8.

Little, A. G. Gesiths, No. 2715.

- Grey Friars, No. 2664.

Mediæval Wales, No. 773 .

Littlehales, H. Churchwardens' Accounts, p. 122.

Littleport Court Baron, No. 1213.

Liv-Esth und Curlandisches Urkundenbuch, No. 1533 .

Liveing, H. G. D. Romsey Abbey Records, Nos. $1138,2671$.

Liverpool, No. 2435.

Livingstone, M. Guide, No. 163.

Lizier, A. L'économie rurale, No. 2311.

Llandaff, Liber Landavensis, No. I350. 
Lloyd, E. Poll Tax Returns, No, 1004.

Lloyd, J. F. Farly Welsh Agriculture, No. 2312.

Lewis's Ancient Laws of Wales, No. 1343 .

Local Government, pp. 210-38.

Local History. p. 78.

- Bibliographies, p. 12.

Local Records, pp. 1:1-25.

No. 284. Committee, Report,

- Inventories of. pp. 29 et seq.

Locke, K. Taunton, No. 2229.

Loders, Cartulaire de, No. tisg.

Lodge, H. C. Anglo-Saxon Land Law, No. 1904.

Lodge, R. Middle Ages, No. 753.

Loesch, H. von. Die Kölner Zunfturkunden, No. is76.

Loewe, G. Fxempla, No. 482 .

Loltie, W. G. Guide 10 the Tower, No. 349.

L London, No. $243^{8}$.

Löher, F. von. Archivlehre, No. 200.

Kulturgeschichte, No, 2812.

Loisel, S. Essai, Nos. 1905, 2038.

Lollards, Nos. 1759, 2568.

Lollardy, No. 1741.

Lomas, S. C. Book of the Pageant of London, No. 2813 .

Lombard Communes, No. 2026, 2383.

Lombardo Archivo Storico, No. 330.

Lombards, No. 1973 .

Lombardy, No. 3023 .

London, Nos. 1586, 1980, 2018 , 2089, $2101,2324,2436-8,2440-1$, $2464.2466,2480,2486,2490$, $2492,2499,2500,2506,2503$, 2511, $2580,2591,2652,2768$, $2813,2818$.

and Middlesex Archaeological Society Catalogue of Antiquities, No. 350.

- Antiquaries, Society of. Catalogue of Manuscripts, No. 263.

Library, No. 14.

Printed Books in

of Antiquities, Nos. 335-6.

Catalogues of Manu.

scripts, Nos. 264-72.
London, British Museum, Fac. similes of Charters, No. 1 so3. Nos. $337^{-2} 4^{2}$.

Reatin Lof Accessions to

Reading Kuom, No. as.

H - 1.iot of Bibliographical

Works, No, 2.

The lint of Books in the

Reading Room, No. 127.

- Subject Index, No. 8.

- Calendar of lester lboks.

No. 3 зु०.

Corporation Wills, p. 187.

- Episcopal Register, p. 117.

_ lay Subsidy, No. 1031.

- Library Catalogue, No. 18.

- Subjert Index, No. ss.

St. Micharl, Curnhill,

Churchwardens Accounts, No.

1195.

- Sit. Paul's Cathedral, No.

2600.

1157.2301.

Domesday of, Nos.

School of Economics, For-

mula Book. Nos. 853, 870, 906. 921, gro.

Exxhequer, No. 1009 .

Receipt Roll of Winchester Pipe

Roll. No. I18s. See Hall, II.

Tower of, No. 1807.

Lniversity Library Cata-

logue. No. is.

Longman, C. J. Archery, No. 622.

Longman's Gazetteer, No. 732.

Longnon, A. l'aris, No. 1378 , 2399.

Longreaux, C.-P. de. La Chambre des comptes de Duché de Bar, No. $1+13$.

Longstafle, IV. H. D. Durham Halmote Rolla, No. 1205.

Lord Chancellors, No. 653.

Lord Iligh Treasurer of Scotland. Accounts of. No. 1978 .

L.ords Auditors, Acis of, No. 1282.

Lords. House of. Nos, 1856, 1859. 1846.

Lords of the Council, Acts of, No. 1284 .

Lorenx, O. Deutschiands Creschichesquellen. No. 100 .

Lorris, No. 1462.

Loserth, 1. Geschichte, No. 754. 
Lothaire, roi de France, Actes de, No. 1424 .

Louis, V., roi de France, Actes de, No. 3424.

Low Countries, pp. 163-6, Nos. 2022, 2347-8, $235^{1}, 2472$.

- Bibliographies, pp. II-12.

- Inventories of Archives, No. 183 .

I.uard, H. R. List of Documents, No. 234.

Relations, No. 2566.

Liibeck, Nos. $1534,{ }_{1582},{ }_{1589}$, 2048.

Lubbock, J. (Lord Avebury). Prehistoric Times, No. 569 .

Luçay, de. Origines, No. 1861.

Lucca, Inventario del Archivio, No. 214.

Luce, S. La Jacquerie, No. 2716.

La France, No. 1746.

Luchaire, A. Communes françaises, No. 2400.

Luders, A. Statutes of the Realm, Nos. 887,1064 .

l.uders, H. Hamburg's Handel, No. 2088.

Ludlow. Documents, No. 1341.

Luneberg, No. 1577.

Lunt, W. E. Mediæval Papacy, No. 2039 .

Luschin von Ebengreuth, A. Allgemeine Münzkunde, No. $55^{2}$.

Oesterreichische Reichsgeschichte, No. 786.

Luxury, History of, No. $275^{\circ}$.

Lynn Regis, Subsidy Roll, No. 1032.

Lyon, Cartulaire de, No. 1366.

Lyon, Registres de, No. 1440.

Lyons, J. Dover, No. 1116.

Lyons, P. A. Ramsey Cartulary, Nos. 1137,1180 .

- De Lacy. Compoti, No. II 56.

Lysons, S. Edward I. in Wales, Nos. $1015,1336$.

- Model Merchant, No. 2717.

Lyte, Sir H. C. Maxwell. Dunster, No. 2154.

- Oxford University, No. 2814.

- Public Record Office Museum Catalogue, No. 346.

MacCaffray, J. Black Book, No. 1301.

McClure, E. Historical Church Atlas, No. 734 .
MacGibbon, D. Castellated Architecture, Nos. 598, 605 .

- Ecclesiastical Architecture, No. 591.

Mackay, H. J. Robinson's Com. mon Law of Kent, No. 2245 .

McKechnie, W. S. Magna Carta, No. 1747.

Mackenzie, W. C. Outer Hebrides, No. 765 .

Mackenzie-Wallace, Sir D. Encyclopædia Britannica, No. 848 .

Mackeson, H. B. Churchwardens' Accounts, p. 122.

Mackinder, H. J. Britain, No. 701.

Mackinnon, J. Early Scotland, No. 2816 .

Edward III., No. 1748.

Mackintosh, $\mathrm{J}$. Civilisation in Scotland, No. 766 .

Maclean, Sir J. Berkeley Manuscripts, No. 23 I.

- Churchwardens' Accounts,

p. 121 , No. 2630 .

Cornwall Poll Tax Account, No. 1000.

— Forest of Dene, No. 2916.

- Gloucestershire Aid, No. 977.

- Smyth's Lives of the Berkeleys, No. 2846 .

- Stannary Roll, No. $295^{6}$.

Trigg Minor, No. 1185 .

Maclear, G. F. Christian Missions, No. 2534.

Macnamara, N. C. Irish Sept, No. 2718.

Macpherson, D. Commerce, Nos. 2040, $293^{8}$.

Rotuli Scotiæ, No. 1247.

Macpherson, H. A. Fowling, No. 2939.

Macquoid, P. Furniture, No. 637.

Macray, W. D. Archives of Denmark, No. 222.

- Libraries in Sweden, No. 225.

Madan, F. Bodleian Library Catalogue, No. 277.

- Books in Manuscript, No. 431.

Madox, T. Exchequer, No. 1967.

— Firma Burgi, No. 2355.

_. Formulare, Nos. 504, 919.

Magdeburg, No. ${ }^{1527}$. 
Magen, A. Comptes d'Agen, No. 1399.

Magna Carta, No. 1747.

Magnusson, E. Shipbuilding, No. 204 i.

Maguire, D. L. Historic Links, No. 2815 .

Mahren, No. 2300.

Mahul, A. Cartulaires, No. 1363.

Maidstone, Kent Archacologieal Society Collections. Catalogue of. No. 351.

Maine, No. 1446.

Maine, H. S. Institutions, No. 2155.

- Village Communities, No. 2156.

Maitland Club. Publications, Nos. $1256,1266,1267,1290$.

Maitland, F. IV. Archaic Communities. No. 2157.

Beatitude of Seisin, No. 2230.

Bibliography of. No. 137.

Bracton's Note Book, No. 1066.

Cambridge Borough Charters. No. $2+17$.

Cambridgeshire Manor, No.

2159.

Canon Law, No. 1906.

Conveyancer, No. 1200.

Crown Pleas, No. 1068.

Dornesday Book, Nos. 1749. $19615,2158$.

English Law, Nos. 1924, 819.

Eyre of Kent, No. 1095.

Gierke's Political Theories. No. 2462, 3011 .

Horne's Mirror of Justices,

No. 1054 .

- I.ittleport Court Baron, No.

1213.

. Iemoranda de Parliamento,

Yos. 898,1065 .

- Northumbrian Tenures, No.

2232.

Origin of Boroughs, No. 2357.

- Parliament at Westminster. No. is6o.

Lelect Crown Pleas, No.

1094.

Select Pleas, Nos. isi4. 2339.

Suitors of the County Court.

No. 2231.
Maitland, $F$. W. Teaching of History, No. 361.

- Three Rolls of the KIng's Court. No. togs.

Township and Horough. No. 2356 .

- Year $1300 k s$, p. 46.

Maitland, S. R. Dark Ages, No. $28 \mathrm{~s} \%$.

Makower, F. Constitutional Hils tory, No. 2567.

Malcolm, J. P. Manners and Customi, No. 2818.

Malden, H. F. Bondsmen, No. 2233.

- Cely Papers, No. $8 \mathrm{~m}$.

Villeinage, No. 2234.

Mallorea, No. 1645.

Malmesbury Rent Roll, No. 1773 .

Malton Priory, No. 2653.

Mamroth, K. Die agrarische Entwickelung Fnglands, No. 2313.

Manchester, No, 1172.

- John Rylands I.ibrary, Catalogue, No. 16.

_ List of Works on Palacography and Diplomatic, No. 45 .

- Municipal Libraries, Catalogue, No. 63.

Mandeville, Geoffrey de, No. 1756.

Manfrin, P. La Dominazione Romana, No. 1713.

Mann, J. S. Social England, No. 839 .

Manners, pp. 253-60.

Manning, O. Surrey, No. 714.

Manor, pp. 210-26.

Court Rolls in private hands, No. 273.

Manorial Customs, p. 106.

330, 138 .

Tenures, p. 106.

Manosque, Cartulaire de, No. 1367.

Manufactures, No. 2035.

France. No. 2046 .

Manwood, J. Laws of the Forest, Nos. 1907, 2917.

Manydown, No. 1174.

Manzoni, I.. Bibliografia degli Statute, No. 123.

- Bibliografia Storica Muni. cipale, No. 124. 
Map, Walter. Latin Poems, No. 1230.

Maps, Catalogues of, Nos. $75^{-6}$.

Marches, Laws of the, No. 1915.

Marches of Wales, Nos. 1341, $1342,1344,1870,1882,2240$.

Marez, G. de. Travail à Bruxelles, No. 2473.

Margerison, S., No. 1105.

Mark, Nos. 2125, 2161, 2173.

Markets, pp. 84,238 , No. 1919 .

Markgraf, H. Liber Fundationis, No. 1547.

Markham, C. A. Northampton Records, No. 1131.

Markham, C. R. Richard III., No. 1750.

Marle, R, von. Hoorn, No. 2429.

Marnier. Etablissements, No. 1386.

Marquardt, J. Römische Staatsverwaltung, No. 1712.

Marsden, R. G. Early Prize Jurisdiction, No. 1908.

- Select Pleas, Nos. 1090, 1829.

- Early Prize Jurisdiction, No. 1908.

Marseille. Cartulaire de l'abbaye de Saint Victor, No. 1355.

Marshall, G. W. Genealogist's Guide, Nos. 71,665 .

Marshalsea Court, p. 106.

Marshal's Rolls, Nos. 874, 1946.

Marshes, pp. 264-5.

Martin, C. T. All Saints' College, Oxford, Catalogue of Archives, No. 274.

2819 .

Chancery Proceedings, No. 2819. logue, No. 255.

- Record Interpreter, Nos. 380,464 .

Wright's Courthand, No. 441.

Martin, J. Privately Printed Books, No. 35 .

Martin, M. T. Percy Cartulary, No. 1135 .

Marwick, J. D. Charters relating to Edinburgh, No. 1269.

- Charters relating to Glasgow, No. 1270.

- Early Glasgow, No. 2425.

- Edinburgh Guilds, No. 2474.
Marwick, J. D. Edinburgh Records, No. 1287.

- River Clyde, No. 2419.

Royal Burghs, Records of the Conventions of, No. 1285 .

- Royal Burghs, Setts, of, No. 1272.

Marychurch, No. 2654 .

Mas Latrie, L. de. Chronoligie, No. 519.

Droit de Marque, No. No. 2043.

- L'officium Robarie, No. 2042.

- Recueil des Traités, No. 1379.

Masons, No. 2504 .

Massé, H. J. L. J. Pewter Plate, No. 2507.

Massingberd, W. O. Ingoldmells Accounts, No. 1166.

- Ingoldmells Court Rolls, No. 1210.

- Lincolnshire Sokemen, Nos. 2235, 2719.

- Ormsby-cum-Ketsby, No. 2160.

Matthew, F. D. Wyclif's English Works, No. 1242.

Matthews, J. Welsh Records, No. 1471 .

Matthews, J. B. Money-lending, No. 1909.

Mätzner, E. Altenglische Sprachproben, No. 404 .

Maurer, G. von. Einleitung, No. $216 \mathrm{r}$.

Maxstoke Priory, No. 2655.

Mayer, E. Zoll, Kaufmannschaft und Markt, No. 2044.

Mayhew, A. L. Middle English Dictionary, No. 404A.

—- Promptorum, Nos. 38I, 405.

Mazzatinti, G. Gli Archivi, No. 326.

Inventare, No. 327.

Mazzinghi, T. J. Sanctuaries, No. 2608.

Mead, W. E. Prologue of Wife of Bath's Tale, No. 2889.

Mcasures. See Weights.

Measures of Land, No. 2318.

Meddelanden fran Svenska Riksarkivet, No. 226.

Meddelelser fra det Danske Rigsarkiv, No. 223. 
Meddelelser fra det Norske Rigsarkiv, No. 224.

Medicine, Nos. 2985, 2988.

Meinardus, O. Üsundenbuch, No. 1525.

Meister, A. Grundriss, Nos. 108, $370,432,505,520,608,833$.

Meizen, A. Siedelung, Nos. 747. 2162.

Urkunden, No. 1538.

Melrose Abbey, No. 1258.

Mely, F. de. Bibliographie, No. 136.

Menger, L. F.. Anglo-Norman Dialect, p. 46.

Menmuir, C. Durham Domes. day Book, No. 2423.

Mepal, No. $25^{87}$.

Meray, A. Cours d'Amour, No. 2820 .

libres precheurs, No. 2821 . Trouveres, No. 2822.

Merchants Adventurers, No. 2037. Alien, No. 202 ?.

Shipping, Nos. 2037, 2509.

Taylors, Nos. 2511, 2512.

Merchants. Alien, No. 2021.

- Custom of, p. 106.

Dublin Guild of, No. 2505.

Statute of, P. 93.

Mereweather, H. A. Borough and Municipal Corporations, No. $235^{-8}$.

Merioneth. Sheriff's Roll, No. 1337.

Merlet, R. Cartulaire, No. 1357.

Merot, L. Ambassades Anglaises, No. 901.

Merovingians, No. 1951.

Merrifield, M. P. Painting, No. 644 .

Merryweather, F. S. Bibliomania, No. 450.

Cilimmerings, No. 2823 .

Merton Priory, No. 2656.

Metcalfe, W. M. Paisley Charters, No. $126 \%$.

Methoid, T. T. Hepworth, No. 2131.

Metivier, G. Dietionnaire, No. 393.

Mever, P. Debat, Nos. 1228, $147^{2}$.

Documents Manuserits, No. 303 .

Ugo Terahh, No. 1477.

Mézières, No. 1461 .
Mlall, E. Title Deeds, No. as9o.

Michel, F. Bordeaux, No. 3414.

- Commerce, No. zo46.

- Licoswais en France. No.

sous.

Races Maudites, No. szo.

Roles Gascons, No. 868.

Middle Ases, Histories of, p. 72.

Middlehant, No. 2657.

Middlesborougli, No. 2658.

Middiesex. Antiquitirs, No. $5 \%$.

- Domesday Tables, No. 2a84. Foresis, No. 29009.

Middleton, J. H. Illumlnated Manuscripts, No. 459.

Migne, J. P. Nouvelle Encyclopedie, No. 433 .

- I'atrologiae Latinae, No. 1623.

Mignon, Robert. Inventaire de. No. 1398.

Milbourn, T. Vintners' Company. No. 2515.

Military History, p. 77.

- Orders, pp. 2009-10.

Millard, J. E. Basingstoke, No. 2408.

Miller, S. H. Fenland, No. 2932.

Mills, p. 265.

Mills, C. Chivalry, No. 2824.

Mills, J. Justiciary Rolls, No. 1323.

Mitman, H. H. Latin Christl. anity, No. 2535 .

Milnc, P. L'Impot des Aides. No. 1960 .

Minerva, No. 32.

Mines, pp. 263-266.

Ministerial Proceedings, Empire. p. 169 .

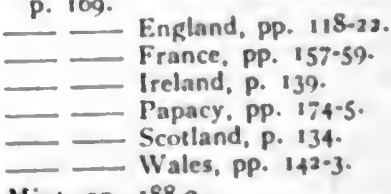

Mint, pp. 188-9.

_ Catalogue of Coins. No. 345.

Constitution of. No. 553.

Miracle Plays, No. 2836 .

Mirot, l. French Archives, p. 30.

Misis, Rotuli de, No. 879.

Missions, Christian, No. 2534.

Mitchell, E. B. Hawking. No. 2923. 
Mitchell, WV. Law Merchant, No. rolo.

Moisy, H. Glossaire, No. 394.

Moke, H. G. Moeurs des Belges, No. 2825 .

Molandon, B. de. Comptes d'Orleans, No. 1402.

Molard, F. Banque de St. Georges, No. 2047.

-_ Esquisses, No. 2826 .

Molesme Cartulaires, No. 1360.

Molinier, A. Obituaires français, No. 2604.

Sources, No. 92.

Molinier, C. Inquisition, No. 2536.

Mollat, G. La Fiscalité, Nos. $2538,2570$.

Möller, W. Lehrbuch, p. I3.

Mollwo, C. Das rote Buch, No. 1565 .

Die ältesten lübischen Zollrollen, No. 2048.

- Handlungsbuch, No. 1592.

Molmenti, P. Venice, No. 802.

Mommsen, T. Roman Empire, No. 1713 .

Monachism, No. 2546.

Monaci, E. Archivio Paleografico, No. 481 .

Monasteries, Nos. 2031, 2543 , 2554.

Monastic Economy, pp. 244-9.

-_ Life, No. 2547.

Towns, No. 2404, 2555.

Monasticism, Nos. 2533, 2550.

- Women under, No. 2880.

Monasticon Anglicanum, Nos. $1117,1158$.

Money-lending, Law of, No. 1909.

Monks, No. 2537.

Monmouthshire, No. 2188.

Monod, G. Bibliographie, No. 93.

Montalembert, C. F. R. de. Monks of the West, No. 2537.

Montelius, A. Kulturgeschichte, No. 2828 .

- Sveriges Hednatid, No. 2827.

Montgomery Charters, No. 1328 .

Montgomery, WV. E. Land Tenure, No. 2236.

Monticolo, G. I Capitolari, No. 1632.

Montmorency, J. E. G. de. Education of Women, No. 288I.
Montpellier, Nos. I 455, 2394.

Coutoumes de, No. 1934.

Coutumier bourguignon, No. 1445.

Moore, M. F. Two Select Bibliographies, Nos. 46, 138 .

Moore, N. Study of Medicine, No. 2985.

Moore, S. A. Fisheries, Nos. $1911,2940$.

- Foreshore, No. 1912.

- Forest of Dartmoor, No. $2918,2237$.

Moore, H. S. Fisheries, Nos. $1911,2940$.

Moors in Spain, No. 808.

Moralities, No. 2836 .

Moray, History of, No. 719.

Morel, O. Chancellerie royale, No. 1795 .

Morice, B. Marshalsea, No. I779.

Moris, H. Cartulaire, No. I374.

Morkill, J. W. Roundhay, No. 2163.

Morley, H. Bartholomew Fair, No. $25^{2} 7$.

Morris. Specimens of Middle English, p. 46.

Morris, J. E. Archers at Creçy, No. 1822 .

- Local History, No. 125.

Welsh Wars, No. 1830.

Morris, M. C. F. Nunbarnholme, No. 2164.

Morris, R. H. Chester, No. 2418.

Morris, IV. Architecture, No. $5^{80}$.

Morris, W. A. Frankpledge System, Nos. 1913, 2340.

Morton, Registrum Honoris de, No. 1259.

Morton, J. Ancren Riwle, Nos. $1225,2886$.

Moule, H. J. Weymouth Documents, No. 293.

Moulney, No. 2628.

Mowat, J. L. G. Alphita, No. 421.

Mugnier, F. Savoyards, No. 2721.

Mühlbacher, E. Regesta Imperii, No. 1514 .

Muir, R. Liverpool, No. 2435.

Müller, D. A. von. Oesterreichische Stadtrechte, No. ${ }^{1563}$.

Müller, J. Wissenschaftlichen Vereine, No. 201. 
Muller, P. L. Lijst van oorkonden, No. 1487 .

Muller, S. Manuel, No, 190.

- De Registers. No. 1494.

Mullinger, J. B. Cambridge Uni. versity, No. 28 a9.

Munch, P. A. Aslak Bolt's Jordebog, No. 1666.

-. Norges gamle Love, No. 1055. 812.

Norske Folks Historie, No.

- Pavelige Nuntiers Regn. skabs. No. 1674.

- Registrum, No. 1670.

Munford, G. Norlolk Domesday. No. 2314.

Municipul Accounis, France, p. 158.

Corporations, Report of Commissioners, No. 2361.

- Documents, lreland, No. 1307.

- History, pp. 226-8.

14.

Registers, France, p. 161.

Munro, R. Prehistoric Scotland, No. 570.

Müntz, E. La Tappisserie, No. 648.

Mfuratori, T. A. Rerum Italica. rum Scriptores, No. 1627.

Murray, C. J. Primer of Old French, p. 45.

Murray, D. Archeological Survey, No. 571.

Murray, J. A. H. New English Dicrionary, No. 406.

Museums, Catalogues of, pp. 40-3.

Muskett, J. J. Cambridgeshire Subsidies, No. 1022.

Mylne, R. S. Churchwardens" Accounts, p. 122.

Mysc, John. Instructions for Parish Priests, No. 1231.

Mysteries, No, $2 \$ ; 2$.

Nansen, F. In Northern Mists, No. 2049.

Napier, A. S. Crawford Collection, No. 1114.

Naples, No. 3007.

- Nrchivo di Stato, No. a11. Fonte della Storia delli Pro. vincie Napolitan, No. 324.

Narbonne, Inventaire des Archises, p. 20.
Nash, T, R. Worcestershire, No. 7 is.

Nasere, F. Agricultural Com. munity, No. asis.

National Biography, Dictionary of, Ner, 6ro.

National Hlistory, pp. 926.

Natlonal l.ibrary of Wiales. Eib. liothera, No. 17.

Nature, Knowledge of. No. stug.

Naude, W. Die Cietreidehandelspolitik. No. anso.

Navarre, No. 1639.

- roide, le comple des recettes et depenses du, No. 1390, 1321.

Naval Hlistory, Bibliographies, p. 12.

Navy. pp. 77, 189-71.

Neach Charters, No. 13 ag.

Neilson. G. Trial by Combat, No. 1914.

Neilson, N. Customary Renis, No. 2238 .

- Manors of Ramsey Abbey. Nos, $1176,2316,2660$.

Netherlands, Inventories of Records, pp. 22-3.

Works relating to, Nos. 2015. 2056, 2060, 2095, 2150, 2378.

- Sources. See Low Countries.

Neubotle, Registrum, No. 1260.

Neuburg. C. Zunftgerichtsbar. keit, No. 2475.

Neuburger, M. Geschichte der Medizin, No. agss.

- History of Medicine, No. $29 \$ 6$.

Newbigging. T. Rossendale Forese, No. 2ga4.

Neweastle-upon-Tyne, Nos. 20;6, $244^{2}, 2946,2952$.

Neweastle-under-l.yme, No. sigo.

Newcourt, R. Repertorium, No. 259 ?.

New Forest, No. 2\&97.

New York Public Library, Ldat of works in, relating to Ireland. No. 88.

Nicholas, Pope, Taxation of, Nios. $970,133 \$, 2561$.

Nicholl, J. Worshipful Company of Ironmongers. No. asos.

Nicholls, H. G. Forest of Dean. No. sgog.

- Iron-making. No. $2955^{\circ}$ 
Nichols, F. M. Britton, No. 395 . Nichols, J. Bibliotheca, No. 702. - Leicester. No. 716 .

- Manner and Expenses, No. 197.

- Miscellaneous Antiquities, No. 703 .

Wills, No. I 45 .

Nichols, J. G. Collectanea, No. 655 .

- Grants from the Crown, No. 867.

L Lacock Abbey, No. $26_{51}$.

Nicholson, H. J. B. St. Albans Cathedral, No. 2672.

Nicolas, Sir N. H. Curia Militaris, No. I069.

— Notitia, No. 666.

Privy Council, Nos. 1063, 1862 .

_ Royal Navy, Nos. 825 , I831.

Testamenta Vetusta, No. 1147.

- Wardrobe Accounts, Edward III., No. 975 .

976.

Nicolas Oresme, Nos. 2994, 3016.

— Traité des Monnaies, No. 1473.

Nicolson, W. Leges Marchiarum, No. 1915.

Nield, F. J. British Topography, No. 75 .

Nielsen, O. Dueholms Diplomatarium, No. 1654.

- Kjobenhavns Diplomatarium, No. 1655 .

- Liber Census Daniae, No. 1672.

Nielsen, Y. Bergen, No. 2409.

Niemeyer, N. Fortieth of 1232, No. 1970.

Niese, H. Verwaltung des Reichsgutes, No. 1971.

Niessen, P. von. Neumark, No. 2165.

Nijhoff, I. A. Gedenkwaardigheden, No. 1488.

Nijhoff, M. Bibliographie systematique, No. III.

Nirnheim, H. Handlungsbuch, No. 1593.

Noble, T. C. Ironmongers, No. 2502.

Noel, O. Commerce, No. 836 .

Nomenclature, pp. 45-50.
Nomina Villarum, No. 962.

Nonarum Inquisitiones, Nos. 960, 1012.

Norden, Traeldom i, No. 2702.

Norfolk, Nos. 2289, 2314.

- Assessment, No. 953.

- Pleas, No. 1067.

Norgate, K. England under the Angevin Kings, No. 1751.

Norman Exchequer, Accounts, pp. $157-9$.

Invasion, No. 1744 .

Rolls, Nos. $866,871,872$, 880,895 .

Normandy, Nos. 1730, 2143, 2531, $2699,2700$.

_ Cartulaire Normand, No. I353.

- Coutumiers de Normandie, No. 1449.

Duke of, No. 1791 .

Exchequer, Great Roll of, No. 987 .

- Registre des dons, No. 1382 .

Normans, No. 1722.

Norse Influence, No. 2023.

Norsemen, No. 2762 .

Norsk Historisk Förening, No. I 7 .

Northampton, Church of the Holy Sepulchre, No. 2659. Records, No. II3I.

Northamptonshire Geld Roll, No. 946.

Hidation of, No. 2325. Survey, Nos. 939, 940 .

Northmen, No. 2803 .

Northumberland, Nos. 710, 717 , $214 \%, 2370$.

- Antiquities, No. 1163. Assize Rolls, No. 1088.

Pipe Rolls, Nos. 994-5.

Northumbrian Tenures, No. 2232.

Norway, Bibliography, No. 117 .

- Catalogues of Manuscripts, No. 314 .

- Inventories of Archives, p. 28.

Sources, pp. 154-5, I78.

Works relating to, Nos. $8 \mathrm{r}$ I $3,1666,1670,1673-4,1679,1685$, 2009-11, 2079, 2082, 2541.

Norwegians, No. 1727 .

Norwich, Nos. 1891, 2338, 2371 , 2660, 2661 .

- Leet Jurisdiction, No. 1215 . Records, No. 1132. 
Notarial Doruments, pp. 89-93.

Notes and Queries, General Index, No. 26 .

Nottingham, No. 2800 .

— Pipe Rolls, No. 996.

Records. No. $1 / 33$.

Royal Charters, No. 1134.

Nowgorod. No. 2521.

Noyes, T. H. Sussex Subsidy, No. 1039.

Numismatics. See Coins.

Bibliographies of, pp. 6-7.

Nunbarnholme, No. 2864.

Nunneries, No. 2887 .

Nürnberger Polizel Ordnungen. No. 1562.

Nyrop, K. Cirammaire historique, p. 45.

Nys, E. Histoire du droit, No. 1986.

- Researches, No. 3024.

Oblate Rolls, No. 881.

Ochenkowski, W. von. England's Wirtschaftliche Entwick. elung, No. 837 .

O'Curry. Manuscript Materials, p. 30 , No. 299.

O'Donovan, J. Book of Rights, No. $13: 6$.

Oesterley, H. Wegweiser, p. 31, Nos, $102,322$.

Oettinger, E. M. Bibliographie, No. 72 .

Okehampton Charters, No. 1120.

O'Leary, De L. Richard II., No. 2722.

Oliver, G. Monasticon, No. 1118.

Olivier, Jacme, marchand de Narbonne, No. 1406.

Olrik, A. Nordisk Aandsliv, No. 283 .

Oman, C. W. C. Art of War, Nos. 826, 1832 .

- Dark Ages, No. 755 .

England before the Conquest, No. 1714.

Great Revolt, No. 1752.

History of England, No.

1735.

Political History of England. No. $8: 5$.

Omont, H. Catalogue générale, No. 306 .

_- Collection Phillipps, No. 282. l.istes des recueils de Fac. similes, No. 47.

Openfield System, No. 2267.
Opet, O. Firbrechellehe Stellune der Wiriber. No. sise.

Oppenheim, M. Naval Accoun: No. 1833 .

Royal Navy, No. 1834.

Oppermann, O. Atlas, No. tho.

Ord. C. Crown Jewels, No. gha.

Ordinances, p. 109.

Ordnance Oftice, Facsimiles, p. 83.

Ordnance Survey, Catalogue of Mape, No. 76 .

Ordonnances des rols de France, No. 2423.

Oriental Trade, No. 2036.

Originalia Rolls, Nov. 857. 832.

Orléant, Cartulaire de SalnteCroix d', No. 1358.

- Comptes d'. No. 1403.

Ormerod, G. Chester, Nos. 7is, $236 \%$.

Ormsby-cum-Ketsby, No, 2160.

Orpen, G. H. Ireland, No. 2753.

Ort, C. Merryweather's Bibliomania, No. 450.

Osnabrick. No. 1579.

Ossory Taxation, No. 1312.

Orté, E. C. Pault's Pictures, No. 2833. Trs.

Ottenthal, F. von. Regulac Can. cellariae Apostolicae, No. 1619.

Otter, W. B. Churchwardens" Accounts, p. 121.

Ottino, G. Bibliotheca, No. 328.

Oıto, H. Brielsammlung. No. 2167.

Ouvry, H. A. Nasse's Agricultural Community. No. azis. Trs.

Overhall, W.H. Churchwardens' Accounts, No. sins.

Owen, A. Ancient laws, No. $13+5$.

Owen, E. Marches of North Wales. No. 2340.

Welsh Manuscripts, p. 38. No. 300 .

Owen, George Deseription of Pembrokeshire, Nos. 1344, 1358 .

Owen. 11. Finglish law in Wales, No. 1342 .

_ Georke Owen's Pembrokeshire, Nos. 1344. 1351.

- Shrewsbury, No. at45.

Owen, I. V. D. Fingland and

Burgundy, No. 2os:

Oxford, Nos. afitia-s. 
Oxford, Ashmolean Museum, Catalogue, No. $35^{2}$.

- Bodleian Library Catalogues, Nos. 276-7.

Colleges, Catalogues of Manuscripts, Nos. 274-5, 278-9. - University, No. 2814.

- Account Book, No. 1175.

Padder's Way, No. 2963.

Page, T. W. Umwandlung der Frohndienste, No. 2317.

_- Villainage, Nos. 2239, 2723.

Page, W. Assize Rolls, No. 1088.

- Victoria County History,

Nos. $840,2366,2832$.

Pageants, No. 2845 .

Pagliaini, A. Catalogo, No. 22.

Painters, No. 2892.

Painting, p. 65.

Paisley Abbey, No. 2666.

Paisley Charters, No. 1267.

Palæographical Society, Indices, No. 52 .

$-\frac{1}{469}$ Publications, No. 468 .

Palæography, pp. 50-4.

- Bibliographies, pp. 5-6.

Palgrave, Sir F. Ancient Kalendars, Nos. 155, 922.

- Curiae Regis Rotuli, No. 1078 .

_- Documents, No. 1246.

- Index to Printed Reports of,

No. 154 .

_- King's Council, No. 1863 .

_- Lord and Vassal, No. 2726.

- Merchant and Friar, Nos. 1781, 2725.

- Nomina Villarum, No. 962 .

- Parliamentary Writs, Nos. $883,1062$.

Palgrave, R. H. I. Political Economy, Nos. 422, 849 .

Palliser, F. B. Historic Devices, No. 1836 .

Palmer, A. N. Marches, No. 2240.

Welsh Measures of Land, No. 2318.

- Wrexham, No. $245^{\circ}$.

Palmer, C. F. R. Black Friars, Nos. 2629, 2635, 2645, 2647, $2673,2678-80$.

- Dartford Priory, No. 2639.

_- King's Confessors, No. 1782.
Palmer, W. M. Cambridgeshire Subsidy Rolls, No. 1021.

Paoli, C. Archivio Palaeografico, No. $48 \mathrm{r}$.

Papacy, Sources, pp. 174-6.

$\longrightarrow$ Works relating to, pp. 74-5, No. 2039.

Paper-making, p. 51.

Pappenheim, M. Altdänischen Schutzgilden, No. 2476.

Papworth, J. W. Coats of Arms, No. 691 .

Paquet, L. Lois Forestieres, No. 1917.

Pardessus, J. M. Lois maritimes, No. 1430.

Paris, Nos. $845,1973,2389,2391$, 2392, 2396, 2399.

Cartulaires de, No. 1365.

- Documents, Nos. 1378,1469 , 1474-5.

University of, Documents, No. 1433-4.

W Welsh Records in, No. 1471 .

Parish Clergy, No. 2622.

— Clerks, No. 2574.

L Life, No. 2779.

__ Priests, No. 2696.

Parish, W. D. Sussex Domesday, No. 949.

Parker, F. H. M. Cumberland Pipe Rolls, No. 989.

Parker, J. H. Domestic Architecture, No. 599.

- Glossary, Nos. 423, 608.

Gothic Architecture, No. $5^{89}$.

Parlement de Paris, Actes du, No. 1426.

Parliament, pp. 107-8, 191-3.

- of Ircland, Statutes, Nos. $132 \mathrm{I}-2$.

_- Rolls, Nos. 873, 1060-1. of Scotland, Acts, No. ${ }^{28} 3$.

Parliamentary Writs, Nos. $88_{3}$, 1062.

Parliamento, Memoranda de, No. 898.

Parmentier, A. Album historique, No. 631 .

Parochial Economy, pp. 244-9.

- System, No. $255^{\mathrm{I}}$.

Parow, IV. Compotus Vicecomitis, No. 1972.

Partington, S. W. Danes in Lancashire, No. 1715.

Pastimes, Nos. 2767, 2773, 2853 . 
Pastor, L. Geschichte dex Päpste. No. 793 .

Patent, Letters, Pp. 1136 .

Patent Rolls, Nos. 884-5, 896. 893.

Duchy of Lancaster. No.

Ireland, No. 1299.

Patetta, F. Ordalle, No, $19: 8$.

Patrick. D. Concilia Scotiae, No. 128 s.

Patrick. R. W. Cochran. Mediaval Scotland, No. 767.

Pattison, R. P. Dunn. Black Prince, No. 1737.

Paul. J. B. Kegistrum magni Sigilli, No. 125?.

Pauli, R. Bilder, No. 2833.

- Hansische Stahlhol, No. 2089.

Paunier. L. Inventaires sommaires, No. 175.

Paviors, Company of, No. 2506.

Payel, J. Handbuch, No. 2988.

Payne, G. Kent Archacological Society's Collections, Catalogue, No. 351.

Payne, J. F. English Medicine, No. 2987.

Payne, W. Tusser's Husbandrie, No. 407.

Payne-Galloway, Sir R. W. Crossbow, Nos. 623, 8335 .

Peacock, E. Index to Archacologia, No. 58.

- Myrc's Parish Priests, No. 1231.

Peak Forest. Nos. $2903,2911$.

Pearce, T. Stannaries, No. 2958.

Pearman, M. T. Bensington, No. 2168.

Pearson, C. B. Churchwardens' Accounts, p. 121.

Pearson, C. H. History of England, Nos. 1716. 1754.

Peasant Revolt, No. 2304.

Peasantry, Nos, $2137,2216,2273$. 2328, $2704,2724$.

Peasants, Nos. 2687, 2707, 2732.

Pease, J. G. Markets, No. 1919.

Pedersen, R. Haldensforholdene, No. $205 a$.

Pedrick, G. Borough Seals, No. 539.

Monastic Seals, No. 538.

Peebles, No. 2443.

- Charters. No. 1271.

Peerage, Nos $654,660,670,671$.
Pexse. S. Curialia, No. 17\% 3 .

Pegor-Ogier, E. lles de Ia Manche, No. 776.

Pembrokeshire. Description of. Nos. 1344, 2351.

Penance, p. 243.

Peninsular Kingdome, Bibliogra. phies, p. 12.

- Histories, p. 75.

8.

- Sources, pp. 153. $177^{\circ}$

Penshurst, Documents at, No. 285.

Perambulations, Forest, p. $26_{3}$.

Percival, C. S. Early Charters. No. 2633 .

Percival, L. Forests, No. ago6.

Percy Chartulary, No. 1135.

Perez-Pujol, E. Historia, No. $2 S_{34}$.

Perigord, No. 2405.

Periodicals, Bibliographies, p. 3.

List of, pp. $281-3$.

Perkins, C. Knights Templars, No. 2113 .

Perrens, F. T. La Detmocratie. No. 2727 .

Perry, J. T. Dinanderie, No. 641.

- Hanseatic League, No. $5^{83}$. - Medizval Architecture, No. 582.

Perrot, G. Table de Revue Archeologique, No. 66.

Peruzzi, S. L. Storia dei Commercio di Firenze, No. 2053.

Peterborough Church. No. 2667.

- Court leet, No. 1216.

- l.iber Niger, No. 117 .

Peter's Pence, Nos. 2557, 2562.

Petil. L. D. Repertorium, No. 12.

Petit de Julleville, L. La comedie. No. 2835 .

Petit-Dutaillis, C. Documents, No. 1500 .

- Soultvement, No. 2731.

- Studies, No. 818.

Petyt. W. Jus Parliamentarium. No. 1864 .

Peuchet, J. Lois de Police, No. 1431.

Pewter Plate, No. 2507.

Pflugk-Harttung, J. von. Acta Pontificum. No. 1598.

Phear, J. B. Hide examined, No. 2319.

Philippa of Hainault, No. 1743. 
Philippe de Beaumanoir, No. 1460. Philippe le Bel, Nos. 1474, 1731, 2020.

Philippe le Hardi, No. 1784 .

Philippe rer. Recueil des Acts, No. 3425 .

Philippi, F. Osnabrückischen Gilde-Urkunden, No. 1579.

Philipps, E. Churchwardens' Accounts, No. 139.

Phillipps Collection, Catalogue de manuscrits, No. 282 .

Phillipps, T. Catalogue of Printed Books, No. 36 .

- Catalogus Librorum Manuscriptorum. No. 280 .

- Index to Cartularies, No. 281 .

- Rotulus Hildebrandi de London, No. 1017.

- Wiltshire Pipe Rolls, No. 998.

Phillimore, E. Lewis's Court of the President and Council of Wales, No. 1900.

Phillimore, Sir R. Ecclesiastical Law, No. 1920.

Phillimore, W. P. W. How to write the history of a family, No. $66 \%$.

_- King's Bench Court Pleas, No. 1074 .

— Pedigree Work, No. 668.

Phillips, L. B. Dictionary, No. 850.

Philobiblon, No. 1234.

Physical Conditions, pp. 262-8.

Picard, E. L'Ecurie, No. 1784.

Pichon, M. Ménagier, No. 1469.

Pickering, Honor and Forest, Nos. 981, 1072, 2910.

Picot, G. Etats généraux, No. $186_{5}$.

Pictures, No. 2833 .

Piepowder, Court of, No. 1886.

Pierce the Ploughman's Crede, No. 1232.

Piers the Plowman, No. 1233.

Pierre de Ham, bailli de Calais, Registre de, No. 1410.

Pigonneau, Cycle de la Croisade, No. 2055.

- Histoire du Commerce, No. 2054.

Pike, L. O. Crime, No. 1921. House of Lords, No. 1866. Year Book. No. 1098.
Pinto de Sousa, J. C. Bibliotheca, No. 116.

Pipe Roll Society, Introduction, No. 382 .

Pipe Rolls, Nos. 988-98, 1013, 1014.

- Ireland, No. 1314.

Pirenne, H. Belgique, No. 779. Bibliographie, No. 113.

Etudes de paleographie et de diplomatique, No. 48 .

Livre de l'Abbé Guillaume

de Pyckel, No. 1496.

Origine. No. 2359.

Recueil de documents, No. 1482 .

Soulevement, No. 1498.

Pisa, No. 2063.

Placita de Quo Warranto, No. 963.

Placitorum Abbreviatio, No. 1083.

Planche, J. R. British Costume, No. 632 .

Planiol, M. Coutumier, No. 1448.

Plate, p. 65, No. 2497.

Plateworkers, No. 2496.

Playfair, E. Neuberger's History of Medicine, No. 2986.

Pleadings, pp. 108-so.

Plummer, C. Alfred the Great, No. 1717 .

- Fortescue's Governance, No. 1922.

Vitae Sanctorum, No. 1325.

Pluralities, No. $25^{84}$.

Poelman, H. A. Geschiedenis, No. 2056.

Poitiers, Cartulaire de l'abbaye de Notre Dame de la Merci Dieu, No. 1376.

Poitou, No. 2455A.

Police, No. $1431,1562,158 \mathrm{r}$.

Political Economy, Dictionary of, No. 849 .

Political History, No. 815 .

- Bibliographies, p. 12.

Poll Tax, Nos. 999-1006. See Subsidies.

Pollard, A. IV. Miracle Plays, No. 2836 .

Pollen, J. H. Furniture, No. 638 .

- Furniture in the Victoria and Albert Museum, No. 347.

Pollock, Sir F. Domesday, No. 2320.

English Law, Nos. 819, 1924. 
Pollock, Sir F. Freeholders, No. 224 '.

- Land I.aws, Nos. 2242, 1923. Oxford l.ectures, No. 3170.

Poloni, No. 1634.

Polybiblion. No. 23.

Pommerellisches Urkundenbuch. No. 1537.

Pontalis, F. 1. Bibliographie gentrale, No. 29.

Pontefract Charters, No. 1120.

Priory, No. 2668.

Poole, R. I. Historical Atlas. No. 735 .

— Medieval Thought, No.3025. Political History, No. 1728. 8 is.

Teaching of Palseography. No. 506.

Poole, S. Lane. Barbary Corsairs, No. 2057 .

Moors, No. 808.

Poole. WV. F. Index to Periodical Literature, No. 27.

Poor, No. 277 t.

Pope, A. Stratton and Grimston, No, 2243.

Population, p. 268.

Population Returns, No. 733.

Porter, A. K. Mediaeval Architecture, No. 581 .

Portugal, Bibliographies, Nos. $115-6$.

Catalogues of Manuscripts, No. 315.

_ Inventories of Archives, p. 28.

Sources, pp. 153-4, 178.

Works relating to, Nos. 809 . 2066.

Posse, O. Analecta, No. 1599.

Potter, F. de. Geschiedenis, No. zło2.

Pottery, p. 65.

Potthast, A. Bibliotheca, No. 80. Regesta, No. 1608.

Poulson, G. Beverley, No. 2412.

Poupardin, R. Liste des Recueils, No. 49.

Powell, E. Peasants' Rising, No. 2568.

Rising in East Anglia, Nos. 1006, 2728.

- Suffolk Return, No. 1003 .

- Suffolk Hundred, No. 1974.

Powell, F. York. Origines, No. 1682 .
Powell, F. York. Corpus, No. $168_{3}$.

Power, D'Arcy. Surgery. No. sokg.

Praestitis Rotuli de, No. 879.

'ratt, H. .1. Cathedral Churches, No. 590.

Prendergast, J. R. Scandinavian Kingdom of Dublin, No. 770.

Pressutti, P. Regesta. No. steds.

Preston Gilds. No. 3453.

Prevost, G. A. Compte des re. cettes et depenses du rol in Navarre, No. 1320.

Price, A. C. Leeds, No. I432.

Price, C. Law of the Exchequer, No. 1925.

Prices, No. 2841.

Priebatsch, F. Markische Handel, No. 2058.

Princes of Wales, No. 656.

Wills of, No. 1145.

Princesses of Fingland, No. 662.

Wales, Wills of, No. 1145 .

Prior, F. S. Gothic Art, No. 392.

Figure Sculpture. No. 639.

Private Instruments, pp. $116-8$.

pp. $93 \cdot 5$.

Privately Printed Books. Bibliographical Catalogue of, No. 35.

Privy Council, pp. 1078 , Nos. 1063. 1855. 1862.

Privy Seals, Rolls of. Edward II., No. 900 .

- Writs and Letters, pp. 89-93.

Privy Seals, Duchy of Lancaster, Calendar, No. 911.

Prix. Documents pour servir a I'histoire des, No. igoz.

Prize Law, No. 1908.

Promptorium Parvulorum, Nos. 381, 405 .

Prou, M. Coutumes de Lorris, No. 1462 .

- Fisquisse, No. 1975.

Liste des Recueils, No. 49.

Manuel, Nos. 434, 477.

- Paleographie, No. 50.

_ Recucil des Actes, No. 1435.

Recuell de Facsimiles, Nos. 474.7.

Prutz, H. G. Rechnungen, No. 1839.

Prutz, H. Entwicklung des Tem. pelherrenordens, No. s116. 
Prutz, H. Finanziellen operationen der Hospitaliter, No. 2 I14.

- Geistlichen Ritterorden, No. 2115.

- Jacques Coeurs Bezichungen, No. 2569 .

Pryce, G. Canynges' Family, No. 2729.

Prynne, W. Aurum reginae, No. Ioo8.

Ptasnik, J. Italia Mercatoria, No. 1634 .

Public Departments, Notes of Materials, No, 146.

Public Health, p. 268.

Public Record Office, Ireland, Deputy Keeper's Reports, No. $165,1304,1314$.

- London, Catalogue of Library, No. 12.

No. 346 .

Catalogue of Museum,

Lists and Indexes, No.

153.

Works, No. 140.

_ _ Reports of Deputy

Keeper, Indexes, No. 154.

- - Publications relating to

Ireland, Nos. 1302, 1303, 1313, 1318.

Public Records, England, Guide to the, No. 160.

_ Handbook to the, No. $16 \mathrm{I}$.

- Scotland, Guide, No. I63.

Pughe, W. O. Cambrian Biography, No. 669 .

Pulling, $A$. Order of the Coif, No. 2730.

Puschmann, T. Geschichte der Medizin, No. 2988.

Putnam, B. H. Statute of Labourers, No. 1926.

Putnam, G. H. Books, No. 451.

Pynson. Dives et Pauper, No. 1229.

Quadripartitus, No. I057.

Quantin, M. Cartulaires, No. 1361 .

Quedlinburg, No. 1536.

Queens of England, No. 677.

Wilis of, No. 1145 .

Quiclserat, J. Costume, No. 2837.

Quo Warranto, Placita de, Nos. 963,1084 .
Ragg, F. W. Feoffees of the Cliffords, No. 2244.

Raine, J. Coldingham Priory, No. 1277.

Durham Depositions, No. 1204.

Durham Wills, p. 117.

Hexham Priory, No. 1165.

York Wills, p. 1 i 7 .

Raithby, J. Statutes of the Realm, Nos. 887, 1064 .

Rambaud, A. Histoire Générale, No. 738 .

Rambaud, J. Doctrines economiques, No. 3026 .

Ramsay, Sir J. H. Accounts, No. 1977.

- Foundations, No. $1718,75^{8}$. Histary of England, Nos. 758-6r .

Statistics, No. 1976.

Ramsey Abbey, Nos. 1176, 2316, 2669.

- Chartulary, No. 1180, 1137.

Rands, W. B. Chaucer's England, No. 2838 .

Rankin, J. T. Index to Facsimiles, No. 5 .

Rappoport, C. Philosophie de l'histoire, No. 371 .

Rashdall, H. Universities, No. 2839.

Rastell, W. Les Termes de la Ley, No. 408.

Ratzinger, G. Geschichte der Kirchlichen Armenpflege, No. 3027.

Rauers, F. Geschichte der alten Handelsstrassen, No. 2968.

Ravenna, No. 1626 .

Rawle, E. J. Exmoor, No. 2907.

Rawlings, G. B. Coinage, No. 1803.

Raynaud, G. Catalogue, No. 308 .

Raynouard, Droit Municipale, No. 2360.

Reading Corporation Diary, No. 283.

Records, No. 1136.

Records, Inventories of, p. 16.

Records, Public, Reports of Commissioners on, Nos. ${ }^{156-8 . ~}$

Red Book of the Exchequer, Nos. $925,968,1964$.

Redstone, L. Sudbury Calendar, No. 287. 
Redstone, V. B. Social Condi. tion, No. 2840 .

Reeves. W. Act of Archbishop Cotton. No. 1309.

Ecclesiastical Antiquities, No. 1318.

Register House. See Ëdinburgh.

Registers, Episcopal, pp. $116 \cdot 7$.

Regions, Ilistories of, pp. 7 1-2.

Reichel, O. J., P. 197.

Churches, No. as9a.

Devon Pipe Rolls, No. 991.

Hulham Manor, No. 2169.

Parochial System, No. 25s.

Treasury of God, No. 2595.

Reims, Archives, p. 20.

Reiss, L. Geschichte des Wahl. rechis, No. 1867.

Relics, p. 244.

René, roi, Comptes du, Nos. 1392. 1397.

Renfrew Archaological Collec. tions, No. 1268.

Rentals, p. 118.

Renwick, R. Lanark Records, No. 1265 .

- Marwirk's Early Glasgow, No. 2425 .

- Pecbles. No. 2443.

- Stirling Charters, No. 1275.

- Records, No. 1288.

Requests, Court of, No. 1853.

Reville, A. L'abjuracio regni, No. 1927.

Reusens, E. Analectes, No. 1483 .

- Eléments, No. 435 .

Revaler Stadirechts, Quellen des. No. 1564 .

- Zollbücher, No, 1590.

Revenue, pp. 197-201.

- Ecclesiastical, pp. $242-4$. Royal, p. 106.

Reville, A. Paysans, No. $273^{2}$. Souldvement, Nō. 2731 .

Revue Archeologique, Table générale, No. 66.

Revue Historique, Tables Genérales, No. 94.

Reynolds, H. E. Wells Cathedral, No. 2676 .

Rheinische Urbare, No. 1549.

Rhewallon and his Sons, No. 1352.

Rhys, J. Celtic Britain, No. 1719. Liber Landavensis, No. 1350.

Welsh l'eople, No, 774.

Kiant, P. E. D. Inventaire, No. 309.
Rlchard III. No. 1750.

Richard of Cornwall. No. 1745.

Richard the Kedelese. No. is3.

Richard de Rury, Ihilobibion, No. 1234.

Richard, J. M. Reglare do l'ierre de Ham, No. 1410.

Richardwon, A. B. Scottish Coin. No. 554 .

Richardion, H. G. Parith Clergy, No, atsz.

Ridpath, G. Horder Hlstory, No. zes.

Riemadijk, T. van. De Tresorle, No. 1796.

Rietuchel, S. Markt und Stadt. No. 2538.

- Untersuchungen, No. s z6s.

Kiga, Nos, aj80, 238 i.

Rigaud. Fudes, Archerfque de Rouen, Journal, No. 1436.

Rigs, J. M. Select Mleas, Now. $926,8007$.

Kijowijk, B. van. Geschiedenis. No. 2439.

Kiley, H. T. London, No. a4ta.

- Munimenta Gildhallow. No. 2890.

Rimmer, A. Anclent Strtet, No. $2 g(x)$.

Rirson, J. Cours Leet, No, 2341.

Rivers, pp. 264 -5.

Riviere, A. Biens Communaux, No. 2363.

Roads, pp. a66-7.

Rober: of Brunne. Handlyng Synne, No. 1235.

Robert, U. Archives departmentales, No. 30 :

- Inventaire des cartulaires. No. 360 .

- Inventaire Sommaire, No. 321.

L I.e cedillt, No. 436.

— 'Testamenis. No. ijso.

- Elat des Catalogues, Nos. $312 \cdot 5$.

Roberts, C. Fine Rolls, No. 87.

Roberts, R. A. Records relating to IVales. No. 167.

Robertsbridge Abbey, Charters and Documents, No. 285.

Robertson, F. W. Hivtorical Fissays, No8, 2173, J552.

Robertron, J. Concifia Scotiae. No. 1381. 
Robertson, W. A. S. Churchwardens' Accounts, p. 122.

Robin Hood, No. 2799.

Robinson, J. A. Flete's Westminster Abbey, No. 2601.

- Gilbert Crispin, No. 2677.

- Westminster Abbey Manuscripts, No. 291.

Robinson, J. H. Western Europe, No. 748 .

Robinson, T. Common Law of Kent, Nos, 1928, 2245.

Rochester Cathedral, No. 2670.

Rock, D. Textile Fabrics, No. 348.

Roeder, F. Die Familie, No. 2246.

Roger-Miles. L. Comment discerner les styles, No. 617 .

Rogers, C. Cupar-Angus Rental Book, No. 1262.

Rogers, J. E. T. Agriculture, Nos. II $77,2321,284$ I.

- Economic Interpretation, No. 2322.

Six Centuries, No. $23^{2} 3$.

Röhricht, R. Deutsche Pilgerreisen, No. 2605 .

Rois de France, Comptes de l'argenterie des, Nos. 1395 , 1396.

Roman Empire, Nos. 741, 2123.

_ fulling, No. 2944.

_- Law, No. 1938.

- Mines, No. 2948, 2951, 2961.

Roman Roads, No. 2965.

Romans, Nos. I693-4, $1703,1706-$ 7,17 I1 $-3,1726$.

Rome, Nos. 799, 800, 803, 2068.

- Relations with, pp. 240-1.

Romsey Abbey, No. 2671.

- Records, No. 1138 .

Rooseboom, M. P. Scottish Staple, No. 2095.

Roscher, W. System der Finanzwissenschaft, No. 1978.

Roserot, A. Registres, No. 1442.

Rosières, R. Société Française, No. 2733 .

Ross, T. Ecclesiastical Architecture, No. 591 .

- Castellated Architecture, Nos. 598,605 .

Rossendale, Forest of, No. 2904. Rössler, O. Grundriss, No. 803 . Rothley Customary, No. 1181 . Rouen, Nos. 1403, 1451, 2393.
Rouen, Eudes Rigaud, archevêque de, No. 1436.

Round. J. H. Alleged Debate on Danegeld, No. 1979.

- Ancient Charters, Nos. 50\%, $85^{2}$.

- Armorial Bearings, No. 672 .

- Burton Abbey Surveys, No. 2326.

Calendar of Documents,

France, Nos. 1303, 1381 .

- Cinque Port Charters, No. 1106.

Commune of London, Nos.

$1785,1980,2324$.

- Danegeld, No. 1981 .

- Domesday Manor, No. 2172.

- Feudal England, Nos. 1755. 1982, 2247.

Gafol, No. 1983 .

- Geoffrey de Mandeville, No. 1756.

- Great Carucage, No. 1984.

Hidation, No. 2325.

- House of Lords, No. 1859.

King's Sergeants, Nos. 1787 , $1985,2248$.

_Leicestershire Survey, No. 934.

Lindsey Survey, No. $93^{8}$.

Northamptonshire Survey,

Nos. 939-40.

Officers of Edward the Confessor, No. 1786 .

- Old English Charters, No.

$5^{10}$ Peerage and Pedigree, No. 671.

- Revenue of Henry III., No. I985.

- Studies in Peerage, No. 670.

Worcestershire Surveys, No. $95 \mathrm{I}$.

Roundhay, No. 2163.

Rousselot, P. Education des femmes, No. 289 I.

Roussillon, No. 2688.

Rowbotham, J. F. Troubadours, No. 2842 .

Rowe, J. B. Cistercian Houses, No. 2553 .

_- Devonshire Domesday, No. 928.

$-\mathrm{S}$. Rowe's Perambulation of Devon, No. 2919.

Royal Burghs of Scotland, Records, No. 1285 . 
Royal Burghs of Scotland, Setts, No. 1272.

Royal Families, No. 651.

Royal Irish Academy Collection. Guide, No. 356.

Royal Statistical Society, Catalogue of Library, No. 13.

Rozitre, F. de. Liber Diurnus, No. $16: 7$.

Rübel, K. Die Franken, No. 787 . - Dortmunder Urkundenbuch. No. isao.

Ruben, E. Registres, No. 1439.

Ruddiman, $T$. Anderson's Thesaurus, No. 483 .

Ruding, R. Annals, No, 1805 . Coinage, No. 555 .

Ruddler, F. IV. Europe, No. 704.

Rudolph, T. Niederlandischen Kolonien. No. 2060.

Ruediger, O. Hamburger Zunft. rollen, No. 1578.

Rushen, P. C. Genealogist's Legal Dictionary, No. 424 .

Russel, C. E. Swallowfield, No. 1788.

Ruthin Court Rolls, No. 1347.

Rutlandshire Domesday, No. 936.

Rye, R. A. Catalogue of London University Library, No. is.

- I.ondon Libraries, No. 142.

Rye, W. Carron Abbey, No. 2627. Crime and Accident, No. 1067.

- Jewish llistory. No. 2780.

Records, No. 159.

- Riot, No. 266 .

Rylands, J. P. Lancashire Subsidy Roll, No. 1028.

Rymer, T. Foedera, Nos. 878, 977 .

Syllabus of, No. 1516 .

S., G. Lechlade Bridge, No. 2974.

Saddlers, Guild of, No. 2508.

St. Albans Cathedral, No. 2672.

St. Andrew's Priory, Scotland, Liber Cartarum, No. 1261.

St. Benet, Abbot of, No. 2304.

Saint-Bertin, Cartulaire, No. 1356.

St. Denys, Histoire, No. 1468.

Saint-Flour, Registres, No. 144 '.

St. Gallen, No. is21.

Saint-Jean-d'Angely, Registres, No. 1443.

Se. Louis, No. 1452 .
St. Mary Bourne, Hants, No. aid4.

St. Paul's. See I ondon.

Salnt-Quentin, No. 145\%.

- Archives, p. 20.

St. Trond, Abbaye de. No. sted

Ste. Palaye. J. H. La Curne de.

Dictionnalre, No. J\%6.

- Mtmoires. No. 2734.

Saints, fives of the Ireland, No. 13 3.

Salmon, A. Coutuma de Beaw. vaisis, No. 1447.

Salt, E. Standon, No 1918.

Salter, H. F. Subvidy, No. 9 ja. $^{2}$

Samaran. C. Fiscalite. Noe. $2538,257^{\circ}$.

Sanctuaries, No. 188ı.

Sancluary. I'rivilege of, p. 244.

Sandeman, G. A. C. Calais, No. 2403.

Sandwich, No. 2444.

Sandrs. C. Consuetudines Kan. ciae, No. 2249.

Sanuto, M. Diagil di. No. 1635.

Sargeaunt, B. F. Weapons, No. 1837.

Sars. J. F. W. Udvigt, No. 813 .

Satchell, T. Dame Jutiana Bhernes" Treatre of fysuhynge, No. 2237.

Sattler, C. Handelsrechnungen. No. 1551 .

Sauley, I. C. de. Documents. No. 1465 .

Saunders, Laurence, Citizen of Coventry. No. 2708.

Savage, E. A. Old Engliah Libraries, No. 452.

Savage, J. Taunton, No. 244;.

Savine, A. Bondmen, No. as51. Copyhold Caves, No. asso. Customary Tenure, No. 2252.

English Monatteries, No. 2554.

Savoyards, No. 272t.

Saxo-Grammaticus, Danlsh His. tory. No. $167 \%$

Saxons, No. 2713.

Scandinavian Kingdoms, Bibliographies, p. 12.

L Sources, pp. 17880.

$75-6$, No. 2493 .

Scandinavian Kingdom of Dublin. No. 770 .

Scargill-Bird. See Bird. 
Schaefer, D. Auszüge, No. 1612. Schäfer, D. Buch des Lübeckjschen Vogts, No. $15^{89}$.

-. Hanse, No. 2090.

- Hansestädte, No. 2091.

Schanz, G. Colonisation, No. 206 I.

- Handelspolitik, No. 2062.

Schaub, F. Der Kampf, No. 2571 .

Schaube, A. Handelsgeschichte, No. 749 .

Konsulat, No. 2063.

Schenk: Traité, No. 1868.

Schive, C. J. Norges Mynter, No. 1679 .

Schlegel, J. F. G. Logbok, No. 1668.

Schlesien, No. 2300.

Schlesische Oderschiff-fahrt, No. 1539.

Schlesische Urkunden, No. 1580.

Schlesischer Dörfer Urkunden, No. 1538.

Schlyter, C. J. Corpus Juris SueoGotorum, No. 1669.

Schmid, R. Gesetze, Nos. 1052, 1929.

Schmidt, C. Petit Supplément, No. 383 .

Schmidt, F. G. A. Handelsgessellschaften, No. 2477.

Schmidt, G. Päpstliche Urkunden, No. 1602.

- Urkundenbuch, Nos. 1523, 1528.

Schmidt, K. Jus primæ noctis, No. 2253.

Schmitz-Kallenberg, L. Diplomatik, No. 505.

Schmoller, G. Grundriss, No. 838 .

_- Strassburger Tucher, No. 1575.

Schneider, G. Finanziellen Beziehungen, Nos. 2064, 2572.

Scholarship, No. 2780 .

Schools, Nos. $2783,2810$.

Schotte, H. Studien, No. 2173.

Schrader, T. Rechnungsbücher, No. 1553 .

Schulte, A. Die Fugger, No. 2068.

- Geschichte des Handels, No. 2069.

_ Urkunden, No. 1543.
Schulte, J. F. von. Geschichte des Canonischen Rechts, No. 3028.

Schulte, J. W. Liber fundationis, No. 1547 .

Schultz, A. Hausliches Leben, Nos. 750, 2843.

Schulz, M. Die Lehre von der historischen Methode, No. 372 .

Schwab, M. Répertoire, No. 143.

Schwabenspiegel, No. 1569.

Schwappach, A. Grundriss, No. 2941.

Schwatz y Lana, F. Coleccion, No. 1647 .

Schwill, F. Europe, No. 751.

Scofield, C. L. Star Chamber, No. 1869 .

- Subsidy, No. 1986.

Scotland, Bibliographies, p. 9 .

- Catalogues of Museums, $p$. 42.

Index to Papers relating to, in Historical MSS. Commission Reports, Nos. 86, 296.

- Inventories of Archives, p. 18.

- Inventories of Local Records, pp. 36- 7 .

Origines Parochiales, No. 712.

Report on Municipal Corporations, No. $236 \mathrm{r}$.

Sources, pp. 129-36, No. 1476.

Statistical Account of, No. 705.

- Topographic Account of, No. 694.

Topographical Dictionary of, No. 729 A.

- Works relating to, pp. 72-3,

Nos. $822,1720,1893,2023,2045$, $2544,2545,2618,2621,2697$, $2772-3,2783,2787,2816,2964$.

Scots, No. 2689.

Scots L.aw, No. 1883 .

Scott, J. Berwick-upon-Tweed, No. 2410.

Scott, W. R. Joint-stock companies, No. 2065.

Scottish Historical Clubs, Catalogue of Publications, Nos. 85 , 164.

King's Household, No. 1764 .

Rolls, Nos. 148, $1244,1247$.

Staple, Nos. 2094-5. 
Scriptorium, pp. 51-2.

Scrope, G. P. Castlecombe, No. 2174.

Self-government, No, 2254 .

Scrutton, T. F. Commons, Nos. 3931, $2255,2327$.

Land in Fetters. No. 1930.

Sculpture, p. 64.

Scutage, No. 1944.

- Rolls, Nos. 874, 1018, 1946.

Seals. Sce Sigillography.

Secretaries, No. if6o.

Ste, H. Classes rurales, No. 2375.

Seebohm, F. Cymric Tribal Sysiem, No. 2176.

- Feudal Tenures. No. 2256.

English Village Community. No. 2178 .

Land Question, No. a 177.

- Tribal System in Wales, No.

2179.

- Tribal Custom in AngloSaxon Law, No. a 180 .

Villainage, No. 2735.

Seeliger, G. Grundherrschaft, No. 2181 .

- Seignorial Authority, No. 2182.

Seignobos, C. Civilisation, No. 739.

Etudes historiques, No. 369 .

Regime ttodale, No. 2257.

Selbourne, Roundel Palmer, Earl of. Ancient Facts, No. 2596.

Selby, W. D. Date-Book, No. 521.

Selden. Fleta, No. 1793.

Selden, J. Fortescue's De Laudibus, No. 1050 .

- Judicature, No.

- Tithes, No. 2597.

Titles of Honour, No. 2736.

Seligman, E. R. A. Economic Interpretation, No. 373.

- Mediaval Guilds, No. 2478.

Semerau, A. Condottieri. No. 1838.

Semi-official Instruments, pp. 935.

Sempringhamites, No. 2620.

Sentchaux royaux, No. 1415.

Sens. Cartulaire, No, 1373.

Stret. F. Moyen Age, No. 2844.

Serldom, Nos. 2201-2, 2206-7. 2224, 2683, 2686, 2692, 2702.

Sergeants, King's, No. 2248.
Serjeantwon, R. M. Church of the Holy Sepulchse, Northamp. ion. No. atso.

Serrure, R. Kepertoire, No. ss.

- Traite. No. S45.

Services. pp. 216-21.

Seyer. S. Bristol, No. 2413.

Bristol Charters. No. 1 sos.

Sharp. T. Pagrants. No. $2 k 45$.

Sharpe, F. Cistercians, No. soid.

Sharpe, M. Greal Ford, No.

2975.

If iddlescx Forests. No. amon.

Middlesex Antiquities, No.

573.

Sharpe, R. R. Letter Books, No.

1130.

London, No. 2441.

London Wills, p. $17 \%$

Shaw, H. Illumination, No. 460.

Shaw, l.. Moray. No. 7 19.

Shaw, IV. A. Bibliography, No.

144.

Currency, No. 556.

Knights, No. 673 .

Shee, R. J. Gneist's Engliah Parliament, No. 1857. Trs.

Sheppard, H. B. Courts Leet. No. 2342.

Sherif's Accompts. No. 1959.

Sheriff's Account (Compotus Vicecomitis). No. 1972.

Sherifl's Farm. No. 1992.

Sheriffs, List of. No. 674-

Sheriff's Roll of Merioneth, No. 1337.

Sherwell, J. W. Saddlers' Guild, No. 2508.

Shillibeer, H. B. Taunton Dean, No. $225^{8}$.

Shillington, V. M. Commercial Relations, p. 27, No. 2066.

Shipbuilding. No. 2041.

Shipp, W. Hutchins' Dorset, No. 2368.

Shipping. No. asog.

Ships, No. 1825 .

Shirley, W. W. Royal Letters, No. 913 .

Shone, W. Vintner's Company, No. 2516.

Shrewisbury, Nos. 2445. 2673.

Poll Tax, No. 1001.

Shrines, p. 244.

Shropshire, Nos. 2373, a961, 2976. Antiquities, No. 708.

Inquisitions, No. $967 \mathrm{~m}$. 
Shropshire, Lay Subsidy Rolls, Nos. $1033,1956$.

Sicily, No. 797.

Siebeck, O. Arbeitssystem, No. 2183.

Sigillography, pp. 57-8.

- Bibliographies, p. 6.

Catalogue of Seals, No. 336.

Sign Manual, Writs and Letters under, pp. 89-93.

Signet, pp. 89-93.

Silberschmidt, IV. Die Commenda, No. 3029 .

Silfverstolpe, C. Historiskt Bibliothek, No. 1675 .

Silver Mines, No. 2959.

Simon, A. T. Wine Trade, No. 2067.

Simon de Beaulieu, Archevêque de Bourges, No. 1437.

Simonnet, J. Documents inédits, No. 1466.

Simonsfeld, H. Fondaco dei Tedeschi, No. 1594.

Simpson, IV. S. Documents, No. 2600.

Sims, R. Walsall Documents, No. 290.

_ Manual, Nos. 286, 675 .

Sinclair, Sir J. Public Revenue, No. 1987.

Sinclair, IV. M. Law Society Library Catalogue, No. 10.

Skaife, R. H. Kirkby's Quest, No. 956 .

Skåne, No. I68I.

Skeat, W. W. Chaucer's Works, No. 1227 .

- Middle English Dictionary, No. 404A.

- Pierce the Ploughman's Crede, No. 1232.

- Piers the Plowman, No. 1233.

- Principles, p. 46.

- Specimens, p. 46.

Skeel, C. A. J. Marches of IVales, No. 1870.

Skene, IV. F. Celtic Scotland, No. 1720.

Skertchley, S. B. J. Fenland, No. 2932.

Skinners' Company, No. 2510.

Slater, G. English Peasantry, No. 2328.

Smedt, C. de. Introductio, p. I2.
Smedt, P. C. de. Principes, No. 374 .

Smirke, E. Silver mines of Byrland, No. 2959.

Smith, A. L. Bibliography, No. 137.

Smith, G. Domesday Book, No. 936.

Smith, J. Toulmin. English Gilds, No. 24\%9.

Smith, L. Toulmin. English Gilds, No. 2479.

- English Manor, No. 2259.

_- Expeditions, No. 1839.

- Jusserand's Wayfaring Life, Nos. 697, 2801. Trs.

__ Leland's Itinerary, Nos. 568, 699.

Smith, W. Dictionary of Christian Biography, No. 684 .

Smyth, J. Berkeley Manuscripts, No. 231.

- Lives of the Berkeleys, No. 2846.

Smyth, IV. H. Sailor's Wordbook, No. 425.

Sneyd, C. A. Island of England, No. 1239.

Soane, G. Domestic Manners, No. 2847 .

Social Conditions, pp. 249-6r.

Social History, pp. 77-8.

- Bibliographies, p. 12.

Sokemen, Nos. 2235, 2719.

Somerset, Nos. 1942, $2611,2887$.

— Feet of Fines, No. 1071.

_- Lay Subsidies, No. 1034 .

— Survey, Nos. 947, 2293.

- Wills, p. 117.

Somersetshire Pleas, No. 1073.

Somerton Court Rolls, No. 1217.

Sommerlad, T. Rheinzölle, No. 2070.

- - Virtschaftliche Thätigkeit, No. 2539.

Somner, W. Gavelkind, No. 2260.

Sotheby, S. and S. L. Watermarks, No. 445 .

Sotheby's, Notes from, No. 135.

South, J. F. Surgery, No. 2989.

Southampton. No. 2446.

South Kensington Museum, Coins, No. 56 .

Seals, No. 54.

Costume, No. 65.

Souttar, R. Short History, No. $75^{6 .}$ 
Soyer, J. Comptes de Blois, No. 1401.

Cartulaise de Blois, Nos. 1360.

- Firude, No. 2364.

Spain. Fitat des Calalogues des Manuscrits des bibliotheques, No. 315.

Facsimiles, p. 54.

Inventories of Archives, p. 27.

- Inventories of Local Records. p. 39.

- Sources, pp. 153-4, 177.

Works relating to, Nos. 806 8, $2127,2279,2720,2834$.

Spangenberg, H. Hol und Zentralverwaltung. No. 1988.

Sparrow, IV. Shaw. Old England, No. 2848 .

- Viomen Painters, No, 2892.

Speck, E. Handelsgeschichte, No. 1728.

Spelman, H. Feuds and Tenures, No. 2261.

- Glossarium, No. 384.

Spence, G. Equitable Jurisdiction, No. 1932.

Spiers, R. P. Fergusson's History of Architecture, No. 579.

Sports. Nos, 2767, 2773, 2788, $2800,2802,2853$.

Staffordshire, Nos. $1187,2274$.

— I.ay Subsidy Rolls, Nos. $1035-6$.

_- Pipe Rolls, No. 997.

Poll Tax, No. 1002.

- Survey, Nos. 948, 2294.

Stage, No. 2757.

Stahlschmidi, J. C. L. London Lay Subsidy Roll, No. 1031.

Stammhammer, J. Bibliographie, No. 145.

Standards, Nos. 655, 679.

Standon Court Rolls, No. 1218.

Stannaries, Nos. 2955-6, $295^{8}$.

Stansfield, J. Kirkstall Abbey Rent Roll, No. 1168.

Staple, pp. 208-9, No. 2439.

_- Inn, No. 2096.

Stapleton, T. Magui Rotuli, No. 987.

Wardrobe Accounts, No. 1797.

Star Chamber, Court of, No. 1860.

- Seiect Cases, No. 1899.
State Trials, No. $1 \mathrm{~cm}$.

Statham, S. P. H. Dowr, No. 2421.

Stationery Office, Calalogue of Record Publications, No. It).

Statutea st Large, Ireland. No. 1324.

of the Realm, Now. $8 \mathrm{gs}, 88 \%$. 1064.

_ of Wales, No. 1340.

Stead, W. T. Annual Index, No. 28.

Steele, R. Bartholomacus Anglt. cus, No. 1226.

Steenstrup. J. C. H. R. Dankke Bonde, No. 2737.

- Normannerne, No. 1722.

Steffens, F. Iateinitche Paläographice. No. $47 \%$.

Steiermark. No. 1542.

Stein, H. Archives, No. 174.

_ Manuel, No. 3 .

Stein, 1.. Franzorstuche Staats. und Rechtsgeschichte, No. 1940.

Siein, WV. Genosenschatt, No. 2009.

Steinacker, H. Diplomatik, No. 505.

Regesta, No. 1513.

Steinhausen, G. von. Deutrke Privatbricle. No. 1596.

- Geschichte der deutschen Kultur, No. 2849 .

Monographien, No. 2850.

Stenton, F. M. Leicestershire Survey, No. 933.

- Types of Manorial Structure, No. 2329.

Stephen. Prior of St. John of Pontefract, No. 2668.

Stephen, 1. Dictionary of National Biography. No. Goa.

Stephens, H. M. Portugal, No. 800.

Stephens, J. A. Borough Corporations, No. $235^{8}$.

Stephens, J. E. R. Trial by Jury, No. 1933 .

Stephens. W. R. W. History of the English Church, No. 8aj.

Simphenson, M. Index to Archaologia, No. $5^{8}$.

Stevens, J. St. Mary Bourne, Hants, No. 3184.

Stevenson, G. H. Finance, Na igfis. 
Stevenson, J. Abingdon Chronicle, No. 1178 .

_- Documents, No. $125^{\circ}$.

- Illustrations, No. 1290.

- Letters and Papers, No. 914.

Stevenson, W. B. Crusaders, No. 2117.

Stevenson, W. H. Crawford Charters, No. III4.

_- Gloucester Records, No. 1122.

- Nottingham Records, No. I 133 .

Old English Charters, Nos. 508-II.

- Royal Charters, No. 1134.

Stewart-Brown, R. Chester Chamberlain's Accounts, No. 974. .

Wirral, No. 2185.

Stieda, IV. Hansisch Venetianische Handelsbezichungen, No. 2093.

- Revaler Zollbücher, No. I590.

Quellen der Handelstatistik, Nos. 126, 323.

Stirling Charters, No. 1275.

- Records, No. 1288.

Stobbe, O. Die Juden, No. 2 I04.

Stockholm, No. I662.

Stockholms Stads Jordeborg, No. 1667.

Stokes, E. Sudbury Muniments, No. 287 .

Stokes, M. McN. Early Christian Architecture, No. 593.

Stokvis, A. M. H. J. Manuel, No. 676 .

Stolzes, J. Entstehung des Gästerechts, No. $285 \mathrm{I}$.

Stone Age, Guide to Antiquities of, No. 342 .

Stopes, C. C. British Freewomen, No. 2893.

Storm, G. Afgifter, No. 1673.

- Norges gamle Love, No. 1685.

- Regesta, No. $165^{8}$.

Stralsund, No. 1588.

Strassburg, Nos. 1543, 1575, 158 I.

Strata Florida Abbey Documents, No. 1332.

Stratford, Extenta Manerii de, No. 1182 .

Stratford, L. Edward IV., No. 1757.
Stratmann, F. H. Middle English Dictionary, No. 409.

Stratton, No. 2243.

Streatfield, G. S. Lincolnshire, No. 1723 .

Strickland, A. Queens of England, No. 677 .

Strutt, J. A. Complete View, Nc. $285^{2}$.

- Dress, No. 633 .

Sports, No. $2 \mathrm{~S}_{53}$.

Stuart, J. Aberdeen Council Register, No. 1289.

- Rotuli Scaccarii, No. 1279.

Stubbs, WV. Bibliography of, No. 144.

Constitutional History, No.

82 I.

Lectures, No. 1724 .

Oxford Lectures, No. $1906 \pi$. Registrum, No. 678 .

Seventeen Lectures, Nos. 375,2854 .

Studer, 'D. Oak Book, No. 397.

Stukeley, W. Itinerarium, No. 706.

Sturbridge Fair, No. 2524 .

Sturgis, R. Avery Architectural Library Catalogue, No. 67.

- Bibliography of Fine Art, No. 68 .

- Dictionary of Architecture, No. 609 .

Stuttgart, No. 1532.

Styffe, C. G. Bidrag, No. 227.

Subsidies, Nos. 972-3, 1986.

Subsidy Rolls, Nos. 1019-43, 1976. See Poll Tax.

Sudbury Muniments, No. 287.

Sueo-Gotorum, Corpus Juris, No. 1669.

Suffolk, No. 1974.

- Lackford Hundred Subsidy Rolls, No. 1026.

_ Materials for History of, No. 288.

- Poll Tax, No. 1003.

- Subsidy Roll, No. ro37.

Suhm, P. F. Scriptores, No. 1678 .

Sully, Henry de, Inquisition of, No. I161.

Sully, Marie de, Livre de, No. 1411.

Superstitions, No. 2697.

Surgery, No. 2989. 
Surrey, Domesday Tables, No. 2384.

History of, No. 714.

Surveys, pp. 959, 118.

- Empire, p. 169.

Surtecs, R. 'burham, No. 720, 24a3.

Sussex, No. saog.

Domesday Book, No. 949.

Subsidies, Nos. 973. 10j8, 1039.

Süssmann, A. JudenschuldentiIgungen, No. aios.

Swansea Charters, No. 8333.

Swayne, H. J. F. Churchwardens ${ }^{\circ}$ Accounts, p. 121.

Sweden, Bibliography, No. 118.

Catalogues of Manuscripts. No. 314.

- Inventories of Archives, p. 28.

Sources, pp. 154-5. $179-80$.

Works relating to, Nos. \$14, $2080,2683,2827-8$.

Svenska Historisk, Föreningen, No. 118.

Sweet. H. Anglo-Saxon Primer. p. 46.

- Anglo-Saxon Reader, p. 46. - Students' Dictionary. No. 410.

Sweetman, H. S. Irish Documents, No. 1308.

Swinden, H. Great Yarmouth. No. 245 :

Switzerland, Nos. 1540, 1541.

_ Inventories of Archives. pp. 23-5.

Synge, M. B. Sncial Lile, No. 2855.

Syria. No. 2059.

Taddei, P. L'Archivista, No. 217.

Talel, G. L. F. Urkunden, Nos. $3624,1628$.

Tailliar. F. Recueil des Actes, No. 1423 .

Taillis, Chronologie des, No. 1415.

Tallage, Nos. 1044. $195^{8}$.

Tangl, M. Päpstlichen Kanzlei Ordnungen, No. 1618 .

Taxwesen, No. 2573.

Tanner. J. Notitla, No. 289.

Tanridge Priory, No. 3674.

Tapestry. p. 65 .

Tardif, A. Droit Prive. No. 1934.

Tardif, E. J. Coutumiers, No. 1449.
Tassin and Toustain. Nouvesu Traite, No. 513.

Tate, C. Alnwiek. No. a\&og.

Taunton, Nos. ass. 134, a44,

Taunton, F. I. Englioh Black Monk: No. s610.

Tavisfock Parith Kecorte, Not. $1196,3977$.

Taxatio Ficcleclavilea, Nos. gro. $133^{8}$.

Taxation, Pp. 197-201.

Taylor, A. Regality. No. 178 g.

Taylor. C. S. Domeaday Survey. No. 3330.

- Pre-Domenday llide, No. 2331.

Taylor, H. O. Clasvical Heritage. No. 2856.

- Mediaval Mind, No. joya.

Taylor, J. Guild of Weavers, No. 2513.

Taylor, S. Gavelkind, No 2960.

Taylor, T. J. Coal Trade, No. 2960.

Taylor, W. King's Lynn, No. 2431.

Taylors, Merchant, Nos. 2s 11.2.

Tedescht, No. 1594.

Telting, A. Fen Berock, No. 2351.

Templars, Nos. 2106-11, 2113. $2116,2118$.

Tenths, Nos, s017, 1045.

Tenures, pp. 106, 216-a1.

Terrier de Loray. Jean de Vienne. amiral de France, No. I\&4a.

Terry. C. S. Catalogue of Scot. tish Historical Clubs, Nos. 8g. 164.

- Index to Papers relating to Scolland, Nos. 86, 296.

Testa de Nevill, No. 964.

Teulet, A. Layettes, No. 169.

Teulet. J. Inventaire, No. t4;6.

Textile Fabrics, No. $4^{2}$.

Thames, Lower, Great Fond over, No. 2975.

Thatches, O. J. Lurope, No. 751.

Thayer, J. B. Preliminary Treafise. No. 1935.

Thegns, No. 2715.

Theiner, A. Codex, No. s60a

- Vetera Monumenta, Na. iss. 
Thérouanne, Evêques de, Régestes des, No. 1435.

Thillier, J. Cartulaire, No. $135^{8}$.

Thiset, A. Eline Goyes Jordebog, No. 1665 .

Tholin, G. Comptes d'Agen, No. 1399.

Thomas of Brantingham, Issue Roll of, No. 984 .

Thomas, A. Etats généraux, No. 1871 .

- Etats Provinciaux, No. 1872 .

Thomas, D. L. Bibliographical List, No. 147.

Thomas, E. C. Richard de Bury's Philobiblon, No. 1234.

Thomas, F. S. Ancient Exchequer, Nos. 1936, 1990.

- Handbook, No. 161.

- Notes of Materials, No. 146.

Thomas, G. M. Urkunden, Nos. 1624,1628 .

Thomas, P. Droit de Propriété, No. 2593.

Thommen, R. Diplomatik, No. 505 .

Urkunden, No. 1541.

Urkundenbuch, No. 1518.

Thompson, E. M. Customary of the Benedictine Monasteries ..., No. 2634 .

- English Illuminated Manuscripts, No $46 r$.

- Palacography, No. 437.

Thompson, J. Leicester, No. 2433.

Thompson, M. E. Somerset Carthusians, No. 2611.

Thoms, IV. J. Book of the Court, No. 1790.

Thomson, D. Weavers' Craft, No. 2514.

Thomson, T. Acta Dominorum Auditorum, No. 1282.

- Acta Dominorum Concilii, No. 1284 .

- Acts of the Parliament of Scotland, No. 1283 .

- Liber Cartarum, No. 126r.

Registrum Honoris de Morton, No. 1259.

— Registrum Magni Sigilli, No. $125 \mathrm{I}$.

Thomson, W. G. Tapestry, No. 649.

Thorpe, B. Analecta, No. 1224.

- Ancient I.aws, No. 1059.
Thorpe, B. Diplomatarium, No. III5.

- Lappenberg's History, No. 1710. Trs.

Thorner Court Rolls, No. 1219.

Thoyts, E. E. Old Documents, No. 438.

Thrupp, J. Anglo-Saxon Home, No. 2857.

Thünen, H. Recherches, No. 2332.

Tiers état, No. 2685 .

Tighe, R. R. Windsor, No. 1809.

Tin, No. 2955.

Tingey, J. C. Norwich Records, No. 1132 .

Tirol, No. 1542.

Tithe, p. 243.

Toller, T. N. Bosworth's AngloSaxon Dictionary, No. 400.

Tölners, Johann. Handlungsbuch, No. 1591.

Tomlins, T. E. Jacob's Law Dictionary, Nos. $418,84 \pi$.

- Statutes of the Realm, Nos. $887,1064$.

Tooting Beck Court Rolls, No. 1220.

Topham, J. Liber Quotidianus, No. 1798 .

- Subsidy Roll, No. 1019.

Topographical Works, List of, No. 140.

Topography, pp. 68-7o.

- Bibliographies, p. 8.

Torr, C. Wreyland Documents, No. 1223.

Toulmin, J. Taunton, No. 2447.

Toulouse, Coûtumes de, No. 1934.

Tournai, Nos. 1497, 1501.

Tours, Registres, No. 1404.

Toustain. See Tassin.

Tout, T. F. Empire, No. 788.

King's Wardrobe, No. 1799.

Political History, Nos. 815, $175^{8}$.

- State Trials, No. 1099.

Tower of London, Guide, No. 349.

Town Origins, Germany, pp. 1712.

Townsend, J. Abingdon, No. 2406.

Towns, pp. 226-38. 1467. 
Toynbee, P. Old French, No. 308.

Trade, Control of, p. tos.

Traill, H. D. Social England. Nos. 839,2858 .

Traube, I.. Zur Pallographie, No. 439.

Tregellis, J. A. Hoddesdon, No. 2186.

Trenholme, N. M. Finglish Mon. astic Towns, Nos. 240y, 2559.

- Right of Sanctuary, No. 2609.

Trevelyan Papers. No. M84.

Trevelyan, G. M. Age of Wycliffe. Nos, 1760, 2738.

Peasants Rising. Nos. 1759. 2568.

Treves, No. 1535.

Trial by Combat, No. 1914.

Tribal Custom, No. 2180.

Tribal System, Nos. 2176, 2179.

Tribalism, No. 2153.

Triest, No. $154^{2}$.

Trigg Minor. No. 1185.

Trinity College, Dublin, Catalogue of Library, No. 6.

Troubadours, Nos. $2822,2842$.

Trouillard, G. Cartulaire, No. 1369.

Troyes, Registres, No. $144^{2}$.

Tuetay, A. Ecorcheurs, No. 2739.

Journal d'un Bourgeois de Paris, No. 1475.

Turner, C. J. R. Vagrants, Nos. 1937, 2859.

Turner, G. J. Exchequer, No. 1991.

Forest Pleas, Nos. 1096. 2920.

Sheriff's Farm, No. 1992.

Turner, J. H. Ilkley, No. 1209.

Turner, Sharon, Anglo-Saxons, No. 2860 .

Turner, T. H. Domestic Architecture, Nos. $600,2861$.

Horticulture, No. 2862.

Turner, W. H. Bodleian Library Catalogue, No. a76.

Turton, R. B. Forest Pleas, No. $107^{2}$.

- Honor and Forest of Pickering. Nins. 981, 2910.

Tuscan Republics, No. 798.

Tuscia, No. 1611.
Twici. IV. Art of Ilunting. No. 2024.

Twios, Sir T. Mlack Book, Na. $18+1$.

- Hracton's De Legibus, No. 1046.

Tysmen, J. K. Danlel. Aid, No. $9,8$.

Uso Teralh, Notaire a fioreal. quier. No. 1477.

Uhthorn, G. Christliche Liebesthatigkeit, No. 3031.

Uim. No. is6s.

Unger, C. K. Diplomatarium, No. 1659 .

Universities. Nos. 2764, 2839.

Unwin, C. Guilde. No. 24ko.

Urseau, C. Cartulalre Nolr, No. 1368.

Utrecht, Nos. 1493, 1494.

Utrechtsche Jaarboeken, No. isou.

Vagranis, Noc. 1937, 3859.

Val de Sainte-Aldegonde, Cartu. laire, No. 1372.

Valdemar II. Jordebos. No. 1673.

Valencia, No. 1644.

Valernes, Comptes. No. 1407.

Valin, L. Duke of Normandy. No. 1791.

Valois, N. Inventaire, No. 1439.

Valor Feclesiasticus, Na. 971.

Valle, L. Bibliographie, No. \$.

Vallet de Viriville, A. Comptes royaux, No. 1393.

Valroger, L. de. Gaule Celtique, No. 17as.

Van den Cheyn, J. Catalogue. No. 319.

Vanderkindere, L. Sitele des As. tevelde, No. 780 .

Van Mieris. F. Groot Charterboek. Nos. 1490-1.

Varenbergh, E. Relations Diplomatiques, No. 2071.

Vascongadas, No. 1637.

Vatican, Archives du, No. ais. See Papacy.

Vaublanc, V. V. II., Vte de. La France, No. 2864.

Vautier, C. Registre de dons. No. 1382 .

Veal, $T$. Domestic Llle, No. 2863.

Verre. Scottish Staple at, No. 2002.

Venice, Nor. 7ns, 803, $15 \%, 1624$. 1625. 1628, 1632, 2069, 2093. 
Verriest, L. Institutions judiciaires, No. 1501.

__ La Charité, No. 1495.

_ La Preuve du Servage, No. 1497.

Vesey, F. Statutes at Large, Ireland, No. 1324.

Viard, J. Jean le Bel, No. 917.

Vibergense Diplomatarium, No. 1653.

Vickers, K. H. Humphrey, Duke of Gloucester, No. 1761.

Victoria and Albert Museum, Heraldry, No. 70.

_ 347.

Textile Fabrics, No. 348.

Victoria County History, Nos. $840,2366,2832$.

Vidal, A. Comptes d'Albi, No. I 400 .

Vienna, Kunst-und-historische Denkmäler in, No. 208.

Vigfusson, G. Corpus, No. 1683 .

Icelandic Sagas, No. 1684 . 1682 .

Vigne, F. de. Moeurs, No. 2481 . Vignie, M. Bastides, No. 2405 .

Vikings, Nos. 1695, 1708.

Vildhaut, H. Handbuch, No. 103.

Village Communities, Nos. 2119 , $2138,2156,2178$.

Villaret, F. de. Comptes d'Orléans, No. 1402.

Villari, L. P. Villari's Florentine History, Nos. 805, 2405A. Trs.

__ Is History a Science? No. 76. Trs.

Villari, P. Florentine History, Nos. $805,2405 \mathrm{~A}$. 376.

Mediæval Italy, No. 804 .

Villefranche, Cartulaire, No. 1359.

Villein Tenure, No. 2199.

Villeinage. Nos. 2211, 2226-7, 2234, 2239, 2263, 2723, 2735, 2741.

Villeins, p. 106.

Vincent, J. M. Municipal Problems, No. 2365.

Vine, Culture of, No. 2286.

Vinogradoff, P. Agricultural Services, No. 2268.
Vinogradoff. P. English Society, Nos. 2264, 2740.

- Folcland. No. 2265.

- Manor. No. 2187.

— Openfield System, No. 2267.

- Oxford Studies, Nos. 2329 , 2238 .

- Roman Law, No. 1938.

- Transfer of land, No. 2266.

- Villainage, Nos. $2263,2741$.

Zur Wergeldfrage, No. 2269.

Vintners' Comipany, Nos. 2515-6.

Vintry, A. Etudes, No. 1993.

Viollet, P. Droit Civil, No. 1939. Etablissements, No. $145^{2}$.

Viollet-le-Duc, E. E. Architecture, No. 610.

- Mobilier, No. 2865.

Virnich, T. Corvey. No. 2866.

Voigt, I. Geschichte Preussens, No. 789 .

Voigt, J. Codex, No. 1507.

Volkeslieder der deutschen, No. 1597.

Vratislaviensis episcopatus, No. 1547.

Wace, $H$. Dictionary of Christian Biography, No. 684 .

Wackernagel, R. Urkundenbuch, No. 1518 .

Wade, J. Public Charities, No. 2867 .

Wadmore, J. F. Skinners' Company, No. 2510.

Wailly, N. de. Variations, No. 1806.

Wainwright, T. Barnstaple Records, No. 228.

Waitz, G. Deutsche Verfassungsgeschichte, Nos. 790, 2343.

Wakefield Court Rolls, No. $122 \mathrm{x}$.

Waldemar, King of Denmark, No. 2091.

Walden, Lord Howard de. Banners, No. 679. See Ellis, T. E.

Wales, Catalogue of Manuscripts, No. 300.

- Catalogue of Welsh Department, Cardiff Free Library, No.

5. Inventories of Archives, $\mathrm{p}$. 19.

- Municipal Corporations, Re. port, No. 2361.

- National Library, Bibliotheca Celtica, No. 17. 
Wales, Roll of expenses of Ed. ward I. in, No. 10is.

Sources, pp. 140-4.

Topographical Dictionary. No. 729.

Works relating to, p. 73 .

Nos. $1830,1870,1882$, $1895-6$. $1900,2153,2176,2179,2188$. $2240,2312,2318,2755.2961$.

Walford, C. Fairs, No. asag.

Walker, B. Domesday of Cam. bridgeshire. No. 2334 .

- Inquisitio, No. 2333.

Walker, J. K. Almonbury, No. 2189.

Walkers' Fuild, No. 2493.

Wall, J. C. Oid English Pasish, No. $25^{83}$.

Shrines, No. 2606.

Wallace Collections at Hertford House, No. 344.

Waller, A. R. Cambridge His. tory of English Literature, No. 2868.

Wallingford. No. 2448.

Walrond, H. Archery, No. 622.

Walsall Documents, No. ago.

Walter, F. Dus alte Wales, No. 775.

Walton Priory. No. 2675.

War, Art of, No. 1832.

Ward, A. W. Cambridge History of English Literature, No. 2868.

Ward. J. Newcastle-under-l,yme, No. 2190.

Roman Era, Nos. 573, 1726.

Wardrobe, p. 188.

Accounts, Nos. 975-6, 1007. Kings, Inventory of Crown Jewels, No. 982.

- Liber quotidianus contrarotulatoris garderobae, No. $9^{85}$.

Warner, G. F. Facsimiles, No. 470.

Giraldi Cambrensis opera, No. 1339.

52.

Warner, R. Antiquitates Culinariae, No. 2869.

Warnkoenig. L. A. Flandrische Staatsgeschichte, No. 781 .

- Franzoesische Staatsgeschichte, No. 1940.

Warrington, No. 3186.
Wartmann, If. Latlaturger Co pialtuch, No. 1582.

Urkundenbuch, No, iss.

War wickshire Subsidy Roll, Sio. 1040.

Watermarks, p. si.

Watkins, C. Copyholds, No. 3370.

Watwon, C. M. Britioh Weighto and Measures, No. 557.

Watson-Taylor, J. Firlestoke. No. as91.

Wattenbach, W. Anleitung, No. 440.

- Deutuchlands Genchichts. quellen, No. 104.

- Schriftwesen, No. 453.

Wauters. A. Analectes. No. i48.

- Table Chronologlque, Nos. 321, 8485 .

Weapons, Nos. 620. 1837 .

Weaver, F. W. Wills, P. 117.

Weavers, Nos. 2583.4.

Weavink. No. asig.

Webb, P. C. Danegeld, No. a 19a.

Wiebb, S. and B. Finglish Loral Government, P. 13. No. 841.

Webes, M. Geschichte der Han. delsgesellschaften, No. jojz.

Wedgwood, J. Staffordshire miates of the Audleys, No. 1887.

Wehrmann. C. Die alteren Lo. beckischen Zunltrollen, Na. 1582 .

Weibull, L. Bibliothek, No. 1681.

Weights and Measures, pp. $5^{8}$.9.

Weiland, L. Constitusiones. No. 1559.

Weinhold. K. Deutschen Frawen, No. 2894 .

Weistumer, No. 1570.

Welch, C. London Antiquities. No. 343 .

- Paviors, No. 3506.

Wells Cathedral, No. $26 j 6$.

Liber Albus, No. IIj9.

Wells, C. 1. The Church, No. 2540.

Wells, S. Drainage, No. 2933.

Wielsford, J. W. W. Sirengeh of England, No. 2870.

Welsh Akriculture, Bibliographical List, No. 14\%.

Recorde. No. 1471.

Koll. Sos. 148, 1326.

Welte, B. Kirchenlexicon, No. s5. 
Welti, E. Bernischen Stadtrechnungen, No. 1556 .

Wergeld, No. 2269.

IVesterhoff, R. Twee Hoofdstukken, No. 2934.

Westfalens Papsturkunden, No. 1603 .

Westminster Abbey, Nos. 588, 1808, 2487, 2601.

- Manuscripts, No. 291. - Exchequer at, No. 1991.

- Gilbert Crispin, Abbot of, No. 2677.

- Monastery of St. Peter, No. 2634.

Westmorland, Bridges, No. 2970.

— Pipe Rolls, No. 990. Wills, p. 117 .

Wethered, F. T. St. Mary's, Hurley, No. 2646.

Weymouth Documents, No. 293.

Wetzel, E. Zollrecht, No. 2072.

Wetzer, H. J. Kirchenlexicon, No. 851 .

Whale, T. WV., p. 197.

Wharton, H. Pluralities, No. $25^{8} 4$.

Wheatley, H. B. House of Lords, No. I 859 .

Wheeler, L. Chertsey Abbey, No. 2636.

Wheeler, W. H. Lincolnshire Fens, No. 2935.

Whitby, No. 2449 .

White, C. H. E. Ipswich Great Domesday, No. 931.

Whitefriars, No. 2637.

Whitwell, R. J. Revenue, No. I994.

Wilda, W. E. Gildenwesen, No. 2482.

Willard, J. F. Edward III.'s Negotiations for a grant, No. 1995.

William of Wadington, Manuel de Pechiez, No. 1235.

William Rufus, No. 1740.

Williams, B. Officers in an Oxfordshire Manor, No. 2271.

Williams, E. Staple Inn, No. 2096.

WVilliams, H. S. Historians' History of the World, No. 740.

Williams, J. Barddas, No. 1349 .

— Denbighshire, No. 2193.

L_ Law of real property, No. 2272 .
Williams, J. Rhewallon, No. 1352.

Williams, R. F. English Cardinals, No. 680 .

Williams, T. C. Law of real property, No. 2272.

Williams, W. M. Founders' Company, No. 2492.

Williamson, G. C. Guildford, No. 2426.

Willis, R. Architectural History, No. 2871 .

Wills, pp. r16-7.

- of Diocese of Dublin, No. 1296.

Willson, T. B. Church and State, No. 254 I.

Wilson, J. M. Worcester Compotus Rolls, No. 1189 .

Wiltshire, Nos. 2374, 2563, 2678, 2912.

Archæological and Natural History Society's Library Catalogue, No. 353 .

_- Domesday, No. 950.

- Inquisitions, No. $967 n$.

- Pipe Rolls, No. 998.

Wimbledon Court Rolls, No. 1222.

Winchcomb, Land boc, No. 1140.

Winchester College, No. 2804.

- Episcopal Register, p. I17.

— Pipe Roll, No. I 88.

- Reports on Muniments, No. 292.

__ St. Giles Fair, No. 2526. St. Giles Farm, No. I 4 I.

Windle, B. C. A. Early Britain, No. 574 .

Windmills, No. 2943.

Windsor, No. 1809 .

Wine Trade, No. 2067.

Winston, C. Glass Paintings, No. 642 .

Winter, G. Urkundliche Beiträge, No. 1566 .

Winterbourne Stoke, No. 2219.

Wirral Wapentake, No. 2185.

Wirtembergisches Urkundenbuch, No. 1545 .

Wise, C. Kettering Compotus, No. 1167.

Wittelsbacensia Monumenta, No. 15 I2.

Wittenborg, Hermann und Johann, Handlungsbuch, No. 1592.

Wittich, IV. Grundherrschaft, No. 2194. 
Wittmann, F. M. Monumenta IVittelsbacensia, No. isiz.

Wodderspoon, J. Ipswich, No. 2430.

Wolf, L. Bibliotheca, No. 134.

Wollaston, G. W. Coronation Claims, No. 1793.

Wolowski, M. L., Introduction. No. 3033 .

Women, Position of, pp. 260-1.

Wood, H. Templars, No. a 188.

Woodbine. G. F. Four Law

Tracls, No. 1055.

Woodrufi, C. E. Fordwich, No. 3424.

Woods, No. 1087.

- and Forests, Reports of Commissioners on, No. 2908.

Woodstock Manor, No. 2281.

Woodward, J. Ecclesiastical Heraldry, No. 681.

- Heraldry, No. 682.

IVool Court, No. aog6.

Woollen Industry. No. 2517.

Worcester, Chapter Library, Catalogue of MSS., No. 294.

__ Episcopal Register, p. 117.

- Priory Compotus Rolls, Nos. 1:89-90.

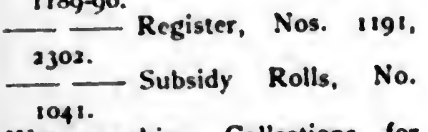

Worcestershire, Collections for history of. No. 7 is.

- Inquisitions, No. $967 n$.

- Surveys, No. 931.

World Histories, p. 71 .

Worms, No. 1546.

Worsaae, J. J. A. Danes, No. 1727. Trs.

Industrial Arts, No. 2484 .

Worsted Manulacture, No. 2538 .

Worth, R. N. Tavistock, No. 1196.

Wrexham, No. 2450.

Wreyland Court Rolls, No. 1223. Wrighe, A. Court Hand, No. 441.

Wrighe, C. T. Hagberg. London library Catalogue. No. 11.

No. ItA.

Wright, J. Dialect Dictionary. No. 412.
Wiright, T. Anglo-latin Satirical Poems. No. 1237.

- Angitosaxon Vocabulario. No. 111.

Archanological Album, No. 375.

- Bingraphla, No. tons.

- Early Ifyoteries, No. as73.

English Peasantry. Nos.

2273. 2743 .

Homes of Other Days, No.

28 s. 5.

Domestic Manners, No. a853.

Political Poemo. No. Isjk.

- Political Songe, No. 1290.

- Popular Treatives, No. 134?.

- Roman Mining. No. mos.

- Walser Map's Latin Poems.

No. 12 30.

Nomenkind. No. akxb.

Writs, Judicial, No. 1058 .

- under the Great Seal, pp.

86-9.

under the Smaller Seals, pp.

89-93.

Wielsh, No. is3o.

Wrottesley. G. Crecy. No. 864.

Foresi Tenures, No. as74.

_ Plea Rolls. No. 1076.

- Staffordshire Lay Subridy

Rolls. Nos. $1035-6$.

Wulcker, R. P. Wright's Anglo-

Saxon Vocabularies, No. 411.

Wurttemberk. No. 1612.

Wutke, R. Urkundenstücke, No.

1539 .

Wyclif. John, Nos. 1760, $273^{8 .}$

Works, Nos. 1242-3.

Wyer, J. I. Bibliography, No. 38.

Wylie, J. H. Agincourt Roll. No. $184^{2}$.

History of England. No. 1762.

Wyinken de Worde. Dives et Pauper, No. 1239.

Wyon. A. B. and A. Seals, No.

Wyss, A. Urkundenbuch, No. 1526.

Yarm, No. $26 \mathrm{mg}$.

Yarmouth, Deeds and Documenis. io. 295 .

Cireat. No. 2451.

Yates. J. Textrinum. No. 2519.

Year-Book of Lcarned Societies. No. 34.

Year Books. Nos. rosg. 1098. 
Yeatman, J.P. Ancient Demesne, No. 2275.

- Derby, No. 721 .

- Peak Forest, No. 2911.

- Pipe Rolis, No. 996.

Yonne, Cartulaires de 1', No. 1361.

York, Nos. 2452, 268 o.

- Episcopal Register, p. 117.

- Municipal Records, No. 1142.

Wills, p. 117.

Yorkshire, Nos. 2675, 2810.

- Accounts of Henry de Lacy, Nos. $1155^{-6}$.

- Deeds, No. 1143.

- Deodands, No. 979.

__ Kirkby's Quest, No. 956.

_- Lay Subsidies, Nos. 1042-3. East Riding, Poll Tax Returns, No. 1004 .

- West Riding, Poll Tax Returns, No. 1005 .
Young, C. G. Liberate Rolls, Nos. 869, 986.

Young, J. Catalogue of Manuscripts, No. 298.

Young, S. Barber Surgeons, No. 2486.

Yver, G. Commerce, No. 2073.

Zeeland, Chancery of, No. 1796.

Zeumer, K. Deutschen Städtesteuern, No. 1996.

- Legum Nationum Germanicarum, No. 1560 .

- Monumenta; No. $5^{13}$.

Quellensammlung, No. 156 r.

Zimmer, H. Irish Element, No. 2874.

Zinkeisen, F. Anfänge der Lehngerichtsbarkeit, No. 2195.

Anglo-Saxon Courts of Law, Nos. 1941, 2335 . 
+

- 1

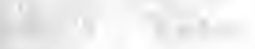
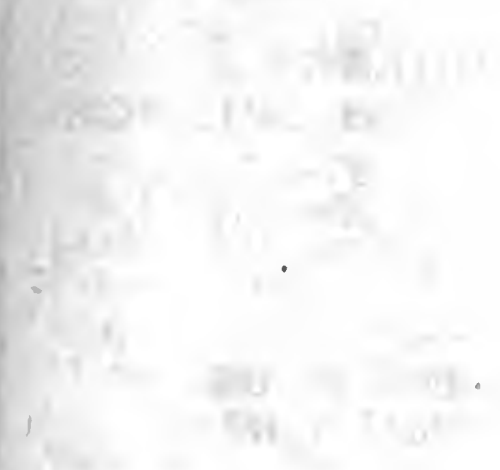

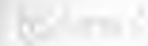

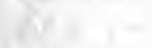

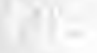

. 1 .

$\sqrt{2}+x^{2}$

$+1$

$-24,5$

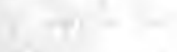

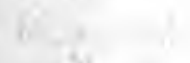

$+x^{3}$

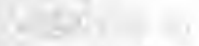

$-1+2-7=1$

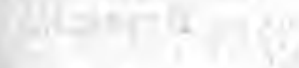

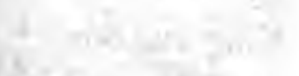

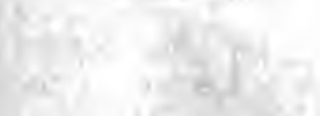

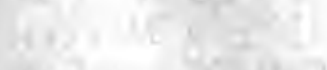

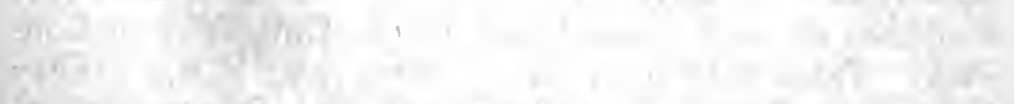

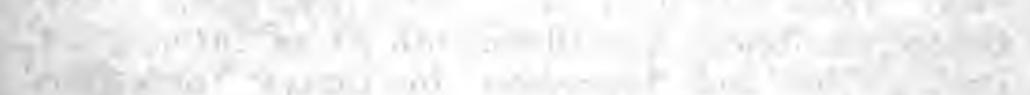

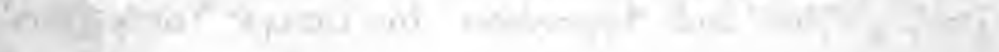




\section{LIST OF STUDIES IN ECONOMICS \& POLITICAL SCIENCE.}

$A$ Series of Monographs by Lecturers and Students connected with the London School of

Economics and Political Science.

\section{EDITED BY THE}

DIRECTOR OF THE LONDON SCHOOL OF ECONOMICS AND POLITICAL SCIENCE.

1. The History of Local Rates in England. The substance of five lectures given at the School in November and December, 1895. By Edwin Cannan, M.A., LL.D. I896; second, enlarged edition, I9I2; $x v$ and 215 pp., Crown 8 vo, cloth. 3s. 6 d. net.

P.S. King and Son.

2. Select Documents Illustrating the History of Trade Unionism. I.-The Tailoring Trade. By $F$. W. Galton. With a Preface by Sidney Webb, LL.B. 1896 ; 242 pp., Cr. 8vo, cloth. 5s. P. S. King and Son.

3. German Social Democracy. Six lectures delivered at the School in February and March, I896. By the Hon. Bertrand Russell, B.A., late Fellow of Trinity College, Cambridge. With an Appendix on Social Democracy and the Woman Question in Germany. By Alys Russell, B.A. 1896 ; 204 pp., Cr. 8vo, cloth. 3s. 6d.

P. S. King and Son.

4. The Referendum in Switzerland. By M. Simon Deploige, University of Louvain. With a Letter on the Referendum in Belgium by M. J. van DEN Heuvel, Professor of International Law in the University of Louvain. Translated by C. P. Trevelyan, M.A., Trinity College, Cambridge, and edited with Notes, Introduction, Bibliography, and Appendices, by Lilian Tomn (Mrs. 
Knowles), of Girton College, Cambridge, Rescarch Student at the School. 1898; $x$ and 344 Pp., Cr. 8vo, cloth. 7s. $6 \mathrm{~d}$. P. S. King and Son.

5. The Economic Policy of Colbert. By A. J. SARGrst, M.A., Senior Hulme Exhibitioner, Brasenose College, Oxford; and Whately Prizeman, 1897, Trinity College, Dublin. 1899; viii and I 38 pp., Cr. 8 vo, clorh. 2s. 6d.

$$
\text { P. S. King and Son. }
$$

6. Local Variations in Wages. (The Adam Smith Prize, Cambridge University, 1898.) By F. W. LAwrence, M.A., Fellow of Trinity College, Cambridge. 1899; viii and 90 pp., with Index and 18 Maps and Diagrams. Quarto, I I in. by $8 \frac{1}{2}$ in., cloth. $8 \mathrm{~s} .6 \mathrm{~d}$. Longmans, Green and Co.

7. The Receipt Roll of the Exchequer for Michaelmas Term of the Thirty-first Year of Henry II. (1185). A unique fragment transcribed and edited by the Class in Palxography and Diplomatic, under the supervision of the Lecturer, Hubert Hall, F.S.A., of H.M. Public Record Office. With thirty-one Facsimile Plates in Collotype and Parallel readings from the contemproary Pipe Roll. I899; vii and 37 pp. ; Folio, $15 \frac{1}{2}$ in. by $11 \frac{1}{2}$ in., in green cloth; 3 Copies left. Apply to the Director of the London School of Economics.

8. Elements of Statistics. By Arthur L. Bowley, M.A., Sc.D., F.S.S., Cobden and Adam Smith Prizeman, Cambridge; Guy Silver Medallist of the Royal Statistical Society; Newmarch Lecturer, I897-98. 500 pp., and 40 Diagrams, Demy 8vo, cloth. I90I ; Third edition, 1907 ; viii and 336 pp. 10s. 6d. net. P.S. King and Son.

9. The Place of Compensation in Temperance Reform. By C. P. Sanger, M.A., late Fellow of Trinity College, Cambridge ; Barrister-at-Law. I901 ; viii and $136 \mathrm{pp}$, Crown 8vo, cloth. 2s. 6d. net. P.S. King and Son.

10. A History of Factory Legislation. By B. L. Hutchiss and A. Harrison (Mrs. Spencer), B.A., D.Sc. (Econ.), London. With a Preface by Sidney WebB, LL.B. 1903 ; new and revised edition, $19 \mathrm{I}$, xvi and 298 pp., Demy 8 vo, cloth. 6s. net.

P. S. King and Son. 
11. The Pipe Roll of the Exchequer of the See of Winchester for the Fourth Year of the Episcopate of Peter Des Roches (1207). Transcribed and edited from the original Roll in the possession of the Ecclesiastical Commissioners by the Class in Palæography and Diplomatic, under the supervision of the Lecturer, HuBERT HALL, F.S.A., of H.M. Public Record Office. With a frontispiece giving a Facsimile of the Roll. 1903; xlviii and I00 pp., Folio, I $3 \frac{1}{2}$ in. by $8 \frac{1}{2}$ in., green cloth. I 5 s. net. P.S. King and Son.

12. Self-Government in Canada and How it was Achieved: The Story of Lord Durham's Report. By F. Bradshaw, B.A., D.Sc. (Econ.), London; Senior Hulme Exhibitioner, Brasenose College, Oxford. 1903; 414 pp., Demy 8vo, cloth. 3s. 6d. net.

P. S. King and Son.

13. History of the Commerical and Financial Relations Between England and Ireland from the Period of the Restoration. By Alice Effie Murray (Mrs. Radice), D.Sc. (Econ.), former Student at Girton College, Cambridge ; Research Student of the London School of Economics and Political Science. 1903; 486 pp., Demy 8vo, cloth. 3s. 6d. net. $\quad P$. S. King and Son.

14. The English Peasantry and the Enclosure of Common Fields. By Gilbert Slater, M.A., St. John's College, Cambridge ; D.Sc. (Econ.), London. 1906 ; 337 pp., Demy 8vo, cloth. Ios. 6d. net. Constable and Co.

15. A History of the English Agricultural Labourer. By Dr. W. Hasbach, Professor of Economics in the University of Kiel. Translated from the Second Edition (1908), by Ruth KenYon. Introduction by SiDney WebB, LL.B. I908; xvi and 470 pp., Demy 8vo, cloth. 7s. 6d. net. P. S. King and Son.

16. A Colonial Autocracy: New South Wales under Governor Macquarie (1810-1821). By Marion Phillips, B.A., Melbourne, D.Sc. (Econ.), London. 1909; xxiii and 336 pp., Demy 8vo, cloth. Ios. 6d. net. P. S. King and Son.

17. India and the Tariff Problem. By $H$. B. LeEs Smith, M.A., M.P. I909; I20 pp., Crown 8vo, cloth. 3s. 6 d. net. Constable and Co. 
18. Practical Notes on the Management of Elections. Three Lectures delivered at the School in November, 1909, by Ellis T. Power., LL.B., B.Sc. (Econ.), Fellow of the Royal Historical and Royal Economic Societies, of the Inner Temple, Barrister-at-Law. 1909; $52 \mathrm{pp}, 8 \mathrm{vo}$, paper. 1s. 6d. net.

P. S. King and Son.

19. The Political Development of Japan. By G. E. Uyehara, B.A., Washington, D.Sc. (Econ.), London. xxiv and 296 pp., Demy 8vo, cloth. 1910. 8s. Gd. net. Constable and Co.

20. National and Local Finance. By J. WATsos Grice, D.Sc. (Econ.), London. Preface by Sidney Wras, LL.B. 1910; 428 pp., Demy 8vo, cloth. Ios. 6d. net.

P. S. King and Son.

21. An Example of Communal Currency. Facts about the Guernsey Market-house. By J. THeodore Harkis, B.A., with an Introduction by SIDNeY WesB, LL.B., 1911; xiv and 62 pp., Crown 8vo, cloth, 1s. 6d. net; paper, Is. net.

P. S. King and Son.

22. Municipal Origins. History of Private Bill Legislation. By F. H. SPEncer, LL.B., D.Sc. (Econ.); with a Preface by Sir Edward Clarke, K.C. 1911 ; xi and 333 pp., Demy 8vo, cloth. 10s. 6d. net. Constable and Co.

23. Seasonal Trades. By Various Authors. With an Introduction by SIDNEY WeBb. Edited by SIDNEY WeBB, LL.B., and Arnold Freeman, M.A. 1912; $x i$ and 410 pp., Demy 8vo, cloth. 7s. 6d. net. Corstable and Co.

24. Grants in Aid. A Criticism and a Proposal. By Sidney Webi, LL.B. 1911 ; vii and 135 pp., Demy 8vo, cloth. 5s. net. Longmans, Green and Co.

25. The Panama Canal: A Study in International Law. By H. Arias, B.A., LL.D. 1911 ; xiv and 188 pp., 2 maps, bibliography, Demy $8 \mathrm{vo}$, cloth. Ios. 6d. net.

$$
\text { P.S. King and Co. }
$$

26. Combination Among Railway Companies. By W. A. Robertson, B.A. 1912; 105 pp., Demy 8vo, cloth. 1s. 6d. net; paper, is. net. Constable and Co. 
27. War and the Private Citizen : Studies in International Law. By A. Pearce Higgins, M.A., LL.D. ; with Introductory Note by the Rt. Hon. Arthur Cohen, K.C. I9I 2 ; xvi and 200 pp., Demy 8vo, cloth. 5s. net.

P.S. King and Son.

28. Life in an English Village : An Economic and Historical Survey of the Parish of Corsley, in Wiltshire. By M. F. DaviEs. 1909; xiii and 319 pp., illustrations, bibliography, Demy 8vo, cloth. 10s. 6d. net.

$\tau$. Fisher Unwin.

29. English Apprenticeship and Child Labour: A History. By O. Jocelyn Dunlop, D.Sc. (Econ.), London ; with a Supplementary Section on the Modern Problem of Juvenile Labour, by the Author and R. D. Denman, M.P. I9I 2 ; pp. 390, bibliography, Demy 8vo, cloth. Ios. 6d. net. $\tau$. Fisher Unwin.

30. Origin of Property and the Formation of the Village Community. By J. St. Lewinski, D.Ec.Sc., Brussels. 1913; xi. and 71 pp., Demy 8vo, cloth. 3s. 6d. net.

Constable and Co.

31. The Modern Tendency toward Industrial Combination in some Spheres of British Industry. By G. R. CARTER, M.A. I9I3; xi and 386 pp., Demy 8vo, cloth. 6s. net. Constable and Co.

32. Tariffs at Work: An outline of Practical Tariff Administration. By John Hedley Higginson, B.Sc. (Econ.), Mitchell Student of the University of London; Cobden Prizeman and Silver Medallist. I913; $150 \mathrm{pp}$., Crown 8vo, cloth. 2s. net. P.S. King and Son.

33. English Taxation, 1640-1799. An Essay on Policy and Opinion. By William Kennedy, M.A., Shaw Research Student at the London School of Economics and Political Science. I913; 200 pp., Demy 8vo. 7s. 6d. net. G. Bell and Sons.

34. Emigration from the United Kingdom to North America, 1763-1912. By Stanley C. Johnson, M.A., Cambridge. I9I3; xvi and 387 pp., Demy 8vo, cloth. 6s. net. G. Routledge and Sons. 
35. The Financing of the Hundred Years' War from 1337 to 1360 . By SchuYler B. 'Terry. 1914; xvi and 199 pp., Demy 8vo, cloth. 6s. net. Constable and Co.

36. Social Organisation and Kinship. By W. H. R. Rivers, M.D., F.R.S., Fellow of St. John's College, Cambridge. 1913; viii and 96 pp., Demy 8vo, cloth. 28. $6 d$. net.

Constable and Co.

Series of Bibliographies by Students of the School.

1. A Bibliography of Unemployment and the Unemployed. By F. Isabel Taylor, B.Sc. (Econ.), London. Preface by Sidney Webr, LL.B. 1909 ; xix and 71 pp., Demy 8vo, cloth, 2s. net; paper, Is. 6d. net. P. S. King and Son.

2. Two Select Bibliographies of Mediæval Historical Study. By Margaret F. Moore, M.A.; with Preface and Appendix by Hubert Hall, F.S.A. 1912; pp. 185, Demy 8vo, cloth. 5s. net. Constable and $\mathrm{Co}$.

3. Bibliography of Roads. By Dorotuy Balles: An enlarged and revised edition of a similar work compiled by Mr. and Mrs. Sidney Webb in 1906. With an introduction by Sir George Gibb. 1914; xviii. and 28I pp., Demy 8vo, cloth. I5s. net.

P. S. King and Son.

4. A Select Bibliography for the Study, Sources, and Literature of English Mediæval Economic History. Edited by Hubert Hall, F.S.A. 1913 ; xiii and 350 pp., Demy 8 vo, cloth. 6s. net.

P. S. King and Son.

\section{Series of Geographical Studics.}

1. The Reigate Sheet of the One-inch Ordnance Survey. A Study in the Geography of the Surrey Hills. By ELLEN Sмгти. Introduction by H. J. Mackinder, M.A., M.P. 1910; xix and 110 pp., 6 maps, 23 illustrations. Crown 8 vo, cloth. 5s. net. A. and C. Black. 
2. The Highlands of South-West Surrey. A Geographical Study in Sand and Clay. By E. C. Matthews. I9II; viii and 124 pp., 7 maps, 8 illustrations, 8vo, cloth. 5s. net. $A$. and C. Black.

Series of Contour Maps of Critical Areas.

1. The Hudson-Mohawk Gap. Prepared by the Diagram Company from a map by B. B. Dickinson. 1913; 1 sheet 18 in. by $22 \frac{1}{2}$ in. Scale 20 miles to 1 inch. 6d. net; post free, folded $7 \mathrm{~d}$., rolled gd.

Sifton, Praed and Co. 



$$
7
$$




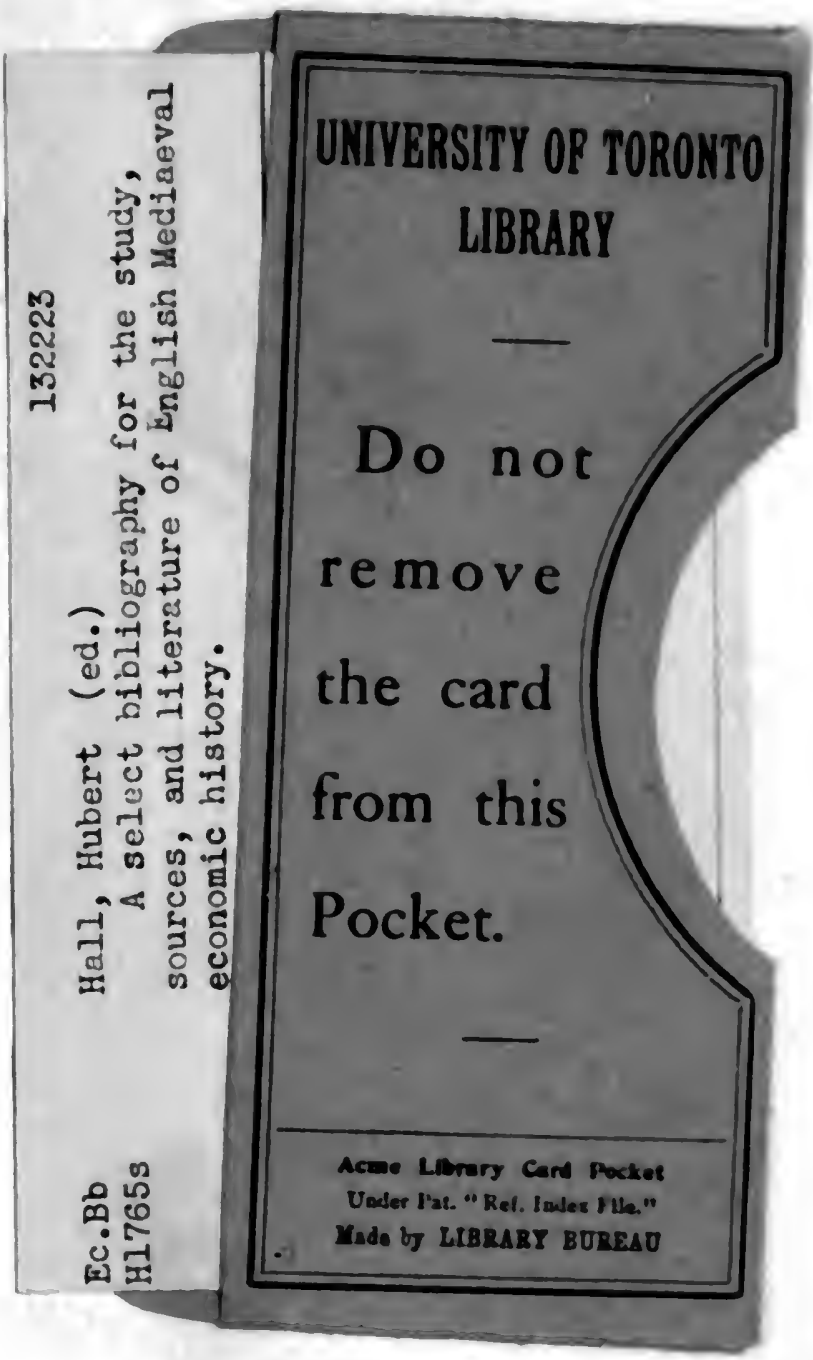


